Prepared in cooperation with the JOHNSON COUNTY STORMWATER MANAGEMENT PROGRAM

Estimation of Constituent Concentrations, Loads, and Yields in Streams of Johnson County, Northeast Kansas, Using Continuous Water-Quality Monitoring and Regression Models, October 2002 through December 2006

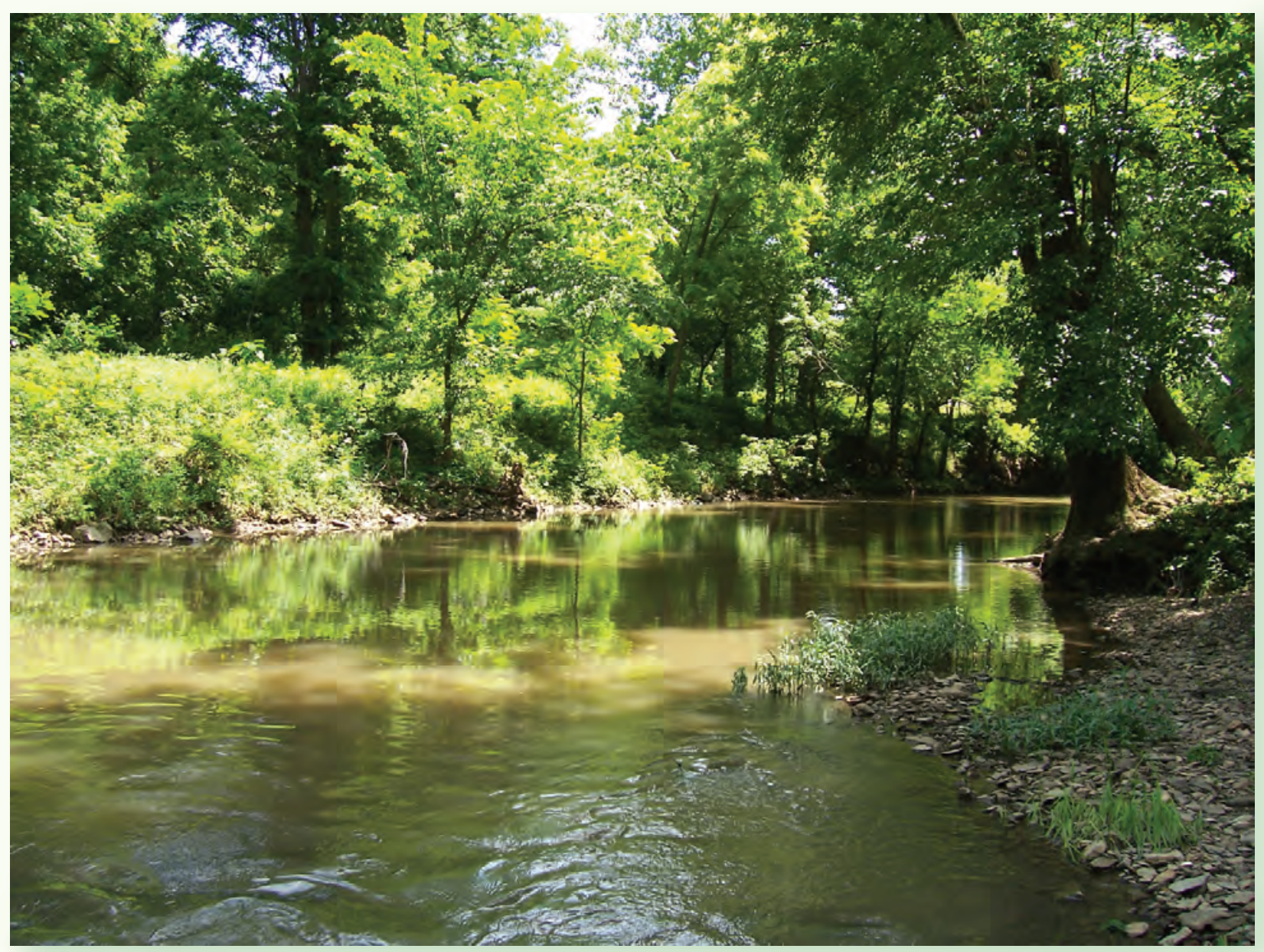

Scientific Investigations Report 2008-5014 
Front cover. Blue River at Kenneth Road, June 2007 (photograph taken by Ryan Smith, U.S. Geological Survey, Lawrence Kansas).

Back cover. (Top) Blue River at Kenneth Road, May 2007 (photograph taken by Teresa Rasmussen, U.S. Geological Survey, Lawrence, Kansas); (Bottom) Indian Creek at State Line Road, March 2004 (photograph taken by Jeff Barnard, U.S. Geological Survey, Lawrence, Kansas). 


\section{Estimation of Constituent Concentrations, Loads, and Yields in Streams of Johnson County, Northeast Kansas, Using Continuous Water-Quality Monitoring and Regression Models, October 2002 through December 2006}

By Teresa J. Rasmussen, Casey J. Lee, and Andrew C. Ziegler

Prepared in cooperation with the Johnson County

Stormwater Management Program

Scientific Investigations Report 2008-5014 


\section{U.S. Department of the Interior DIRK KEMPTHORNE, Secretary}

\section{U.S. Geological Survey \\ Mark D. Myers, Director}

\section{U.S. Geological Survey, Reston, Virginia: 2008}

For product and ordering information:

World Wide Web: http://www.usgs.gov/pubprod

Telephone: 1-888-ASK-USGS

For more information on the USGS — the Federal source for science about the Earth, its natural and living resources, natural hazards, and the environment:

World Wide Web: http://www.usgs.gov

Telephone: 1-888-ASK-USGS

Any use of trade, product, or firm names is for descriptive purposes only and does not imply endorsement by the U.S. Government.

Although this report is in the public domain, permission must be secured from the individual copyright owners to reproduce any copyrighted materials contained within this report.

Suggested citation:

Rasmussen, T.J., Lee, C.J., and Ziegler, A.C., 2008, Estimation of constituent concentrations, loads, and yields in streams of Johnson County, northeast Kansas, using continuous water-quality monitoring and regression models, October 2002 through December 2006: U.S. Geological Survey Scientific Investigations Report 2008-5014, 103 p. 


\section{Contents}

Abstract

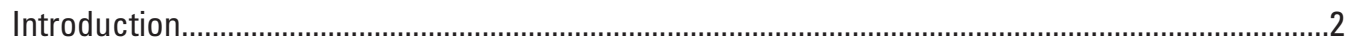

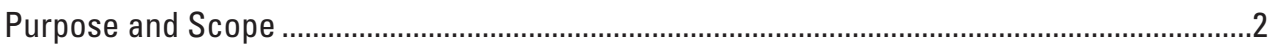

Description of Study Area ......................................................................................................

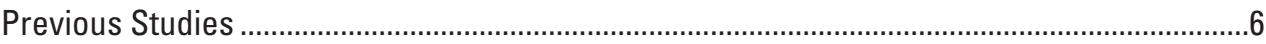

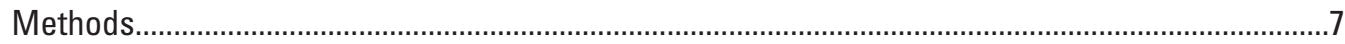

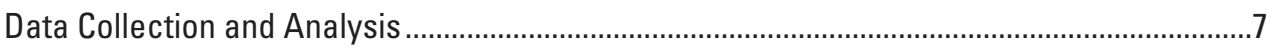

Regression Models............................................................................................................

Estimation of Constituent Concentrations, Densities, Loads, and Yields ...............................17

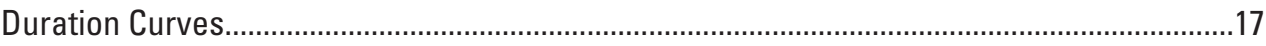

Results of Continuous In-Stream Measurements ....................................................................17

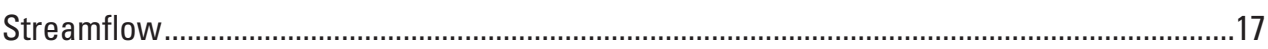

Specific Conductance

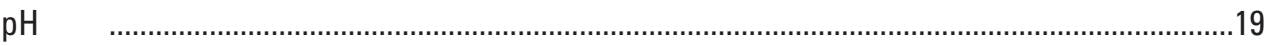

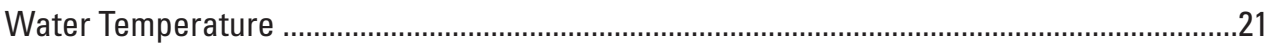

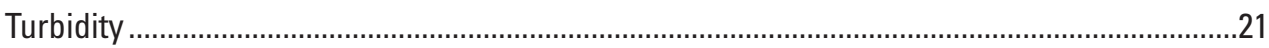

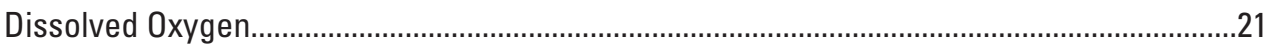

Variability in Streamflow and Water-Quality Measurements...............................................24

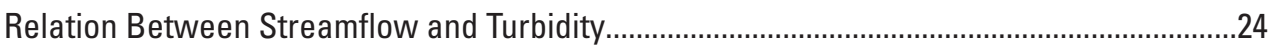

Regression-Estimated Constituent Concentrations, Densities, Loads, and Yields ...........................26

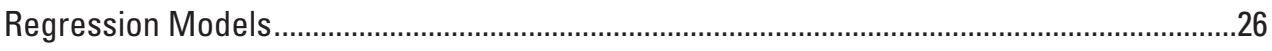

Regression-Estimated Constituents ..................................................................................39

Suspended Sediment and Total Suspended Solids......................................................39

Dissolved Solids, Chloride, and Other Major lons........................................................60

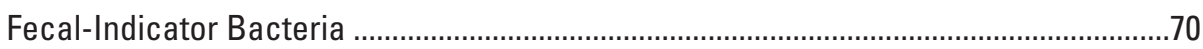

Results of Selected Discrete-Sample Analysis ..........................................................................

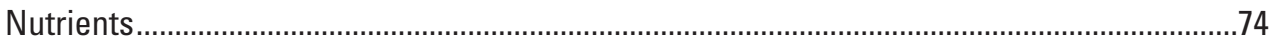

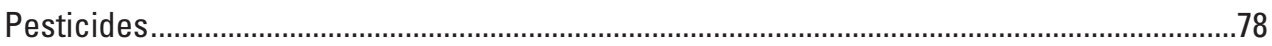

Watershed Characteristics Affecting Water Quality in Johnson County Streams..........................81

Summary and Conclusions.....................................................................................................91

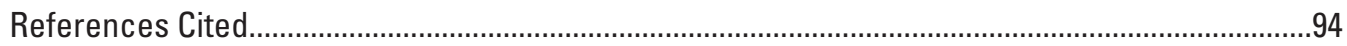

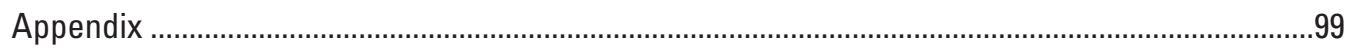

\section{Figures}

1. Maps showing location of monitoring sites, watershed boundaries, and land use, Johnson County, northeast Kansas.

2. Photographs of Kill Creek at 95th Street, one of five continuous water-quality monitoring sites in Johnson County, Kansas, and monitor used to measure continuous, in-stream specific conductance, $\mathrm{pH}$, water temperature, turbidity, and dissolved oxygen 
3-11. Graphs showing:

3. Comparison between suspended-sediment concentrations in samples collected using manual flow-weighted sampling methods and automated samplers at five monitoring sites in Johnson County, Kansas, 2003-06 .

4. Duration curves for measured streamflow at five monitoring sites in Johnson County, Kansas, March 2004 through December 2006

5. Duration curves for measured specific conductance at five monitoring sites in Johnson County, Kansas, March 2004 through December 2006.

6. Duration curves for measured $\mathrm{pH}$ at five monitoring sites in Johnson County, Kansas, March 2004 through December 2006.

7. Duration curves for measured water temperature at five monitoring sites in Johnson County, Kansas, March 2004 through December 2006.

8. Duration curves for measured turbidity at five monitoring sites in Johnson County, Kansas, March 2004 through December 2006.

9. Duration curves for $(A)$ measured dissolved oxygen at five monitoring sites in Johnson County, Kansas, for March 2004 through December 2006 and (B) seasonal dissolved oxygen at the Indian Creek monitoring site for January 2005 through December 2006.

10. Variability in $(A)$ streamflow, $\mathrm{pH}$, water temperature, and dissolved oxygen and $(B)$ specific conductance and turbidity at the Indian Creek monitoring site in Johnson County, Kansas, August 2005.

11. Comparison of continuously measured streamflow and turbidity at the Cedar Creek monitoring site, Johnson County, Kansas, January 2005 through December 2006 .........26

12. Diagram showing common streamflow and suspended-sediment hysteresis patterns, types, and sediment-source explanations

13-34. Graphs showing:

13. Examples of hysteresis patterns in streamflow and turbidity data from selected monitoring sites in Johnson County, Kansas, 2004-05.

14. Comparison of explanatory and response variables for selected water-quality constituent regression models for $(A)$ suspended-sediment concentration, $(B)$ chloride, and (C) Escherichia coli bacteria.

15. Duration curves for estimated suspended-sediment concentration at five water-quality monitoring sites in Johnson County, Kansas, March 2004-December 2006. 51

16. Estimated annual loads and yields for suspended sediment, chloride, and Escherichia coli bacteria at five water-quality monitoring sites in Johnson County, Kansas, 2005-06

17. Duration curves for estimated suspended-sediment load at five water-quality monitoring sites in Johnson County, Kansas, January 2005-December 2006.

18. Cumulative estimated suspended-sediment loads and frequency of exceedance at five water-quality monitoring sites in Johnson County, Kansas, January 2005December 2006.

19. Streamflow and cumulative suspended-sediment load at five water-quality monitoring sites in Johnson County, Kansas, 2005-06.

20. Estimated suspended-sediment load during June 2005 at the Blue River monitoring site, Johnson County, Kansas.

21. Duration curves for estimated chloride concentration at five water-quality monitoring sites in Johnson County, Kansas, March 2004-December 2006. 
22. Frequency and probability of exceeding chloride criteria at the Indian Creek monitoring site, Johnson County, Kansas, January 2005-December 2006.

23. Cumulative estimated chloride loads and frequency of exceedance at five waterquality monitoring sites in Johnson County, Kansas, 2005-06.

24. Seasonal chloride concentration duration curves at the Indian Creek monitoring site, Johnson County, Kansas, January 2005-December 2006.

25. Elevated chloride concentrations during snowmelt as a result of road-salt application at five water-quality monitoring sites in Johnson County, Kansas, JanuaryFebruary 2005

26. Duration curves for estimated Escherichia coli bacteria at five water-quality monitoring sites in Johnson County, Kansas, March 2004-December 2006.

27. Seasonal duration curves for estimated Escherichia coli bacteria density at the (A) Indian Creek and (B) Cedar Creek water-quality monitoring sites, January 2005December 2006.

28. Probability of exceeding Escherichia coli bacteria criteria at the (A) Blue River and $(B)$ Indian Creek water-quality monitoring sites in Johnson County, Kansas, January 2005-December 2006

29. Cumulative estimated Escherichia coli bacteria loads and frequency of exceedance at five water-quality monitoring sites in Johnson County, Kansas, January 2005December 2006.

30. Total annual estimated fecal coliform bacteria loads and loads originating from wastewater-treatment-facility discharges to Blue River and Indian Creek, Johnson County, Kansas, 2005-06....

31. Concentrations of $(A)$ total nitrogen and $(B)$ nitrates as nitrogen in relation to streamflow at five water-quality monitoring sites in Johnson County, Kansas, October 2002-January 2006

32. Concentrations of total phosphorus in relation to streamflow at five water-quality monitoring sites in Johnson County, Kansas, October 2002-January 2006.

33. Annual estimated total nitrogen and total phosphorus loads originating from wastewater-treatment-facility discharges to Blue River and Indian Creek, Johnson County, Kansas, 2005-06

34. Constituent yields and impervious surface area at five water-quality monitoring sites in Johnson County, Kansas, 2005-06.

\section{Tables}

1. Continuous in-stream monitoring sites, contributing drainage areas, estimates of urban and nonurban land-use percentages, and estimated number of septic systems per square mile of drainage area in Johnson County, northeast Kansas .................................

2. Watersheds containing stream segments with 303 (d) listings and total maximum daily loads (TMDLs) completed or being developed, Johnson County, northeast Kansas, 2006

3. Water-quality constituents, units of measurement, laboratory reporting levels, and results of replicate stream sample and blank sample analysis for five waterquality monitoring sites in Johnson County, northeast Kansas, October 2002December 2006. 
4. Summary of continuous in-stream measured data and frequency of exceedance percentiles for streamflow, specific conductance, $\mathrm{pH}$, water temperature, turbidity, and dissolved oxygen at five water-quality monitoring sites in Johnson County, northeast Kansas, 2003-06.

5. Mean daily streamflow, annual streamflow volume, and annual streamflow yield at five water-quality monitoring sites in Johnson County, northeast Kansas, 2004-06.

6. Average annual precipitation in five watersheds of Johnson County, northeast Kansas, 2003-06

7. Relation between hourly streamflow and turbidity measurements at five water-quality monitoring sites in Johnson County, northeast Kansas, 2005-06

8. Regression models and summary statistics for estimating concentrations and densities of selected constituents in water at five water-quality monitoring sites in Johnson County, northeast Kansas, October 2002-January 2006

9. Regression models and statistics for estimating concentrations of selected constituents using suspended-sediment concentration (SSC) in discrete samples from five water-quality monitoring sites in Johnson County, Kansas, October 2002January 2006.

10. Regression-estimated concentrations for selected water-quality constituents at five water-quality monitoring sites in Johnson County, northeast Kansas, January 2005December 2006.

11. Estimated concentrations, loads, and yields for selected water-quality constituents at five water-quality monitoring sites in Johnson County, northeast Kansas, 2005-06 ......52

12. Regression-estimated loads for selected water-quality constituents at five waterquality monitoring sites in Johnson County, northeast Kansas, January 2005December 2006

13. Percentage of annual suspended-sediment load that occurred during the single largest storm runoff for 2005 at five water-quality monitoring sites in Johnson County, northeast Kansas

14. Results of analysis of nutrients in discrete samples collected at five continuous water-quality monitoring sites in Johnson County, northeast Kansas, October 2002January 2006.

15. Results of analysis of pesticides in discrete samples collected at five continuous water-quality monitoring sites in Johnson County, northeast Kansas, October 2002January 2006. 


\section{Conversion Factors, Abbreviations, and Datum}

\begin{tabular}{|c|c|c|}
\hline Multiply & By & To obtain \\
\hline acre-foot (acre-ft) & 1,233 & cubic meter $\left(\mathrm{m}^{3}\right)$ \\
\hline $\begin{array}{l}\text { acre-foot per square mile per year } \\
{\left[\left(\text { acre-ft } / \mathrm{mi}^{2}\right) / \mathrm{yr}\right]}\end{array}$ & 476.1 & $\begin{array}{l}\text { cubic meter per square kilometer per year } \\
{\left[\left(\mathrm{m}^{3} / \mathrm{km}^{2}\right) / \mathrm{yr}\right]}\end{array}$ \\
\hline cubic foot per second $\left(\mathrm{ft}^{3} / \mathrm{s}\right)$ & 0.02832 & cubic meter per second $\left(\mathrm{m}^{3} / \mathrm{s}\right)$ \\
\hline gallon (gal) & 3.785 & liter $(\mathrm{L})$ \\
\hline inch (in.) & 2.54 & centimeter $(\mathrm{cm})$ \\
\hline microgram per liter $(\mu \mathrm{g} / \mathrm{L})$ & 1.0 & parts per billion (ppb) \\
\hline micron $(\mu \mathrm{m})$ & 0.00003937 & inch (in.) \\
\hline mile $(\mathrm{m})$ & 1.609 & kilometer $(\mathrm{km})$ \\
\hline milligram per liter (mg/L) & 1.0 & parts per million (ppm) \\
\hline milliliter $(\mathrm{mL})$ & 0.0338 & ounce, fluid (oz) \\
\hline million gallons per day (Mgal/d) & 0.04381 & cubic meter per second $\left(\mathrm{m}^{3} / \mathrm{s}\right)$ \\
\hline pound (lb) & 453.6 & $\operatorname{gram}(\mathrm{g})$ \\
\hline pound per acre (lb/acre) & 1.121 & kilogram per hectare $(\mathrm{kg} / \mathrm{ha})$ \\
\hline square mile $\left(\mathrm{mi}^{2}\right)$ & 2.590 & square kilometer $\left(\mathrm{km}^{2}\right)$ \\
\hline ton & 0.9072 & megagram $(\mathrm{Mg})$ \\
\hline ton per day (ton/d) & 0.0105 & kilogram per second $(\mathrm{kg} / \mathrm{s})$ \\
\hline $\begin{array}{l}\text { ton per square mile per year } \\
{\left[\left(\text { ton } / \mathrm{mi}^{2}\right) / \mathrm{yr}\right]}\end{array}$ & 0.3503 & $\begin{array}{l}\text { tonne per square kilometer per year } \\
{\left[\left(\mathrm{t} / \mathrm{km}^{2}\right) / \mathrm{yr}\right]}\end{array}$ \\
\hline
\end{tabular}

Temperature in degrees Celsius $\left({ }^{\circ} \mathrm{C}\right)$ may be converted to degrees Fahrenheit $\left({ }^{\circ} \mathrm{F}\right)$ as follows:

$$
{ }^{\circ} \mathrm{F}=\left(1.8 x^{\circ} \mathrm{C}\right)+32 .
$$

Temperature in degrees Fahrenheit $\left({ }^{\circ} \mathrm{F}\right)$ may be converted to degrees Celsius $\left({ }^{\circ} \mathrm{C}\right)$ as follows:

$$
{ }^{\circ} \mathrm{C}=\left({ }^{\circ} \mathrm{F}-32\right) / 1.8 \text {. }
$$

Horizontal coordinate information is referenced to the North American Datum of 1983 (NAD 83).

Specific conductance is given in microsiemens per centimeter at 25 degrees Celsius $\left(\mu \mathrm{S} / \mathrm{cm}\right.$ at $\left.25^{\circ} \mathrm{C}\right)$.

Concentrations of chemical constituents in water are given either in milligrams per liter (mg/L) or micrograms per liter $(\mu \mathrm{g} / \mathrm{L})$.

Densities of fecal-indicator bacteria are given in colonies per 100 milliliters of water (col/100 mL). 



\title{
Estimation of Constituent Concentrations, Loads, and Yields in Streams of Johnson County, Northeast Kansas, Using Continuous Water-Quality Monitoring and Regression Models, October 2002 through December 2006
}

\author{
By Teresa J. Rasmussen, Casey J. Lee, and Andrew C. Ziegler
}

\section{Abstract}

Johnson County is one of the most rapidly developing counties in Kansas. Population growth and expanding urban land use affect the quality of county streams, which are important for human and environmental health, water supply, recreation, and aesthetic value. This report describes estimates of streamflow and constituent concentrations, loads, and yields in relation to watershed characteristics in five Johnson County streams using continuous in-stream sensor measurements. Specific conductance, $\mathrm{pH}$, water temperature, turbidity, and dissolved oxygen were monitored in five watersheds from October 2002 through December 2006. These continuous data were used in conjunction with discrete water samples to develop regression models for continuously estimating concentrations of other constituents. Continuous regressionbased concentrations were estimated for suspended sediment, total suspended solids, dissolved solids and selected major ions, nutrients (nitrogen and phosphorus species), and fecalindicator bacteria. Continuous daily, monthly, seasonal, and annual loads were calculated from concentration estimates and streamflow. The data are used to describe differences in concentrations, loads, and yields and to explain these differences relative to watershed characteristics.

Water quality at the five monitoring sites varied according to hydrologic conditions; contributing drainage area; land use (including degree of urbanization); relative contributions from point and nonpoint constituent sources; and human activity within each watershed. Dissolved oxygen (DO) concentrations were less than the Kansas aquatic-life-support criterion of $5.0 \mathrm{mg} / \mathrm{L}$ less than 10 percent of the time at all sites except Indian Creek, which had DO concentrations less than the criterion about 15 percent of the time. Concentrations of suspended sediment, chloride (winter only), indicator bacteria, and pesticides were substantially larger during periods of increased streamflow. Suspended-sediment concentration was nearly always largest at the Mill Creek site. The Mill Creek watershed is undergoing rapid development that likely contributed to larger sustained sediment concentrations. During most of the time, the smallest sediment concentrations occurred at the Indian Creek site, the most urban of the monitored sites, likely because most of the streamflow originates from wastewater- treatment facilities located just upstream from the monitoring site. However, estimated annual suspended-sediment load and yield were largest annually at the Indian Creek site because of substantial contributions during storm runoff. At least 90 percent of the total annual sediment load in 2005-06 at all five monitoring sites occurred in less than 2 percent of the time, generally associated with large storm runoff. About 50 percent of the 2005 sediment load at the Blue River site occurred during a single 3-day storm, the equivalent of less than 1 percent of the time. Suspended-sediment concentration is statistically related to other water-quality constituents, and these relations have potential implications for implementation of best management practices because, if sediment concentrations are decreased, concentrations of sediment-associated constituents such as suspended solids, some nutrients, and bacteria will also likely decrease. Chloride concentrations were largest at the Indian and Mill Creek sites, the two most urban stream sites which also are most affected by roadsalt runoff and wastewater-treatment-facility discharges. Two chloride runoff occurrences in January-February 2005 accounted for 19 percent of the total chloride load in Indian Creek in 2005. Escherichia coli density at the Indian Creek site was nearly always largest of the five sites with a median density more than double that of any other site and 15 times the density at the Blue River site which is primarily nonurban. More than 97 percent of the fecal coliform bacteria load at the Indian Creek site and near the Blue River site originated from nonpoint sources in 2005 and 2006. In Johnson County, generally as impervious surface area increased, so did total annual yield for sediment, chloride, and indicator bacteria in 2005 and 2006. Total nitrogen discharged from the two Indian Creek wastewater-treatment facilities accounted for at least two-thirds of estimated total nitrogen load at the downstream Indian Creek monitoring site in 2005 and 2006. Total phosphorus load from the Indian Creek wastewater-treatment facilities was at least 90 percent of the total phosphorus load at the downstream monitoring site in 2005 and 2006. On the Blue River about 40 percent of the total nitrogen load in 2005 and 70 percent of the total nitrogen load in 2006, when stormwater runoff was less, originated from wastewater-treatment discharge. One-fourth (in 2005) to one-half (in 2006) of the 
downstream total phosphorus load in the Blue River originated from WWTF discharges.

The results presented in this report may be used to better understand fluctuations of concentration and load during changing seasons and flow conditions and to assess waterquality conditions relative to total maximum daily load goals, National Pollutant Discharge Elimination System requirements, and water-quality standards. The information also will be useful for evaluating loading characteristics, such as range and variability, and for determining effectiveness of best management practices. The continuous streamflow data and estimated concentrations, densities, and loads are available at http://ks.water.usgs.gov/Kansas/rtqw/.

\section{Introduction}

Johnson County is one of the most rapidly developing counties in Kansas, with a population increase of about 90 percent in the last 25 years, from 270,269 in 1980 (University of Kansas, 2006) to an estimated 516,731 in 2006 (U.S. Census Bureau, 2007). Population growth and expanding urban land use affect the quality of county streams, which are important for human and environmental health, water supply, recreation, and aesthetic value.

Urbanization generally affects streams by altering hydrology, geomorphology, chemistry, and biology (Paul and Meyer, 2001). Increases in impervious surface area from urbanization result in increased surface runoff, larger flood streamflows (Dunne and Leopold, 1978), and floods that peak more rapidly (Hirsch and others, 1990) but are shorter in duration (Seaburn, 1969). Changes in channel depth and width occur in response to changes in streamflow and sediment supply (Dunne and Leopold, 1978). Stream-water chemistry is affected by increases in most water-quality constituents including nutrients such as ammonium and nitrate, major ions, suspended solids, metals, and hydrocarbons (Porcella and Sorenson, 1980; U.S. Geological Survey, 1999), which can be attributed to nonpoint-source runoff, wastewater-treatment-facility discharges (Paul and Meyer, 2001), and other sources. Biological communities are affected by changes in habitat and stream hydrology and chemistry.

Effective implementation of total maximum daily loads (TMDLs) and the National Pollutant Discharge Elimination System (NPDES) program requires quantification and documentation of water-quality conditions and changes. Constituent concentrations and load information can be used to identify degraded stream segments, to evaluate compliance with water-quality standards, and to compare water-quality conditions over space and time. Required by the Federal Clean Water Act and established by States, TMDLs define the maximum quantity of a contaminant that a water body can receive and still meet water-quality criteria (Kansas Department of Health and Environment, 2004a). The U.S. Environmental Protection Agency's (USEPA) NPDES Phase II Stormwater
Program is designed to reduce effects of urban stormwater runoff on stream-water quality. Water-quality criteria for constituents discussed in this report are listed in Appendix 1.

Five watersheds in Johnson County (Blue River, Cedar Creek, Indian Creek, Kill Creek, and Mill Creek, fig. 1, table 1) contain stream segments that have been included by the Kansas Department of Health and Environment (KDHE) on the section 303(d) list (Kansas Department of Health and Environment, 2006a) for water-quality impairments (table 2). Kansas water-quality criteria for Escherichia coli (E. coli) bacteria require stream sites to be classified and regulated according to designated use and accessibility (Appendix 1). Segments of the Blue River and Cedar, Kill, and Mill Creeks have been designated as primary contact recreation Class B, defined as being open to and accessible by the public with landowner permission. Designated uses for Indian Creek have not been determined by the State (Kansas Department of Health and Environment, 2005).

The NPDES program, which affects most municipalities in Johnson County, requires that best management practices (BMPs) be established to reduce runoff effects to urban streams (U.S. Environmental Protection Agency, 2005). In the early 1990s, Johnson County adopted a 1/10-cent sales tax to fund stormwater projects and created the Stormwater Management Advisory Council (SMAC). SMAC, composed of representatives from each of the county's 20 cities, is an advisory group that makes recommendations to the county regarding the stormwater management program (Johnson County Stormwater Management Program, 2007).

In 2002, the U.S. Geological Survey (USGS), in cooperation with the Johnson County Stormwater Management Program and the financial oversight of SMAC, began an investigation to characterize the water-quality conditions of Johnson County streams. Initial study efforts described the effects of nonpoint and selected point contaminant sources on stream-water quality and the relation of contaminant sources to land use using analytical results from stream-water and streambed-sediment samples (Lee and others, 2005). A subsequent phase of the study characterized biological conditions of Johnson County streams (Poulton and others, 2007). The most recent part of the study investigated constituent concentrations, densities, loads, and yields using continuous in-stream sensor measurements.

\section{Purpose and Scope}

The purpose of this report is to describe methods and summarize results for providing continuous estimates of water-quality constituent concentrations, densities, loads, and yields in five Johnson County watersheds using continuous in-stream sensor measurements and regression models. Differences in water quality are described relative to watershed characteristics including hydrologic conditions, contributing drainage area, land use, point and nonpoint sources, and human activity. Specific conductance, $\mathrm{pH}$, water temperature, 


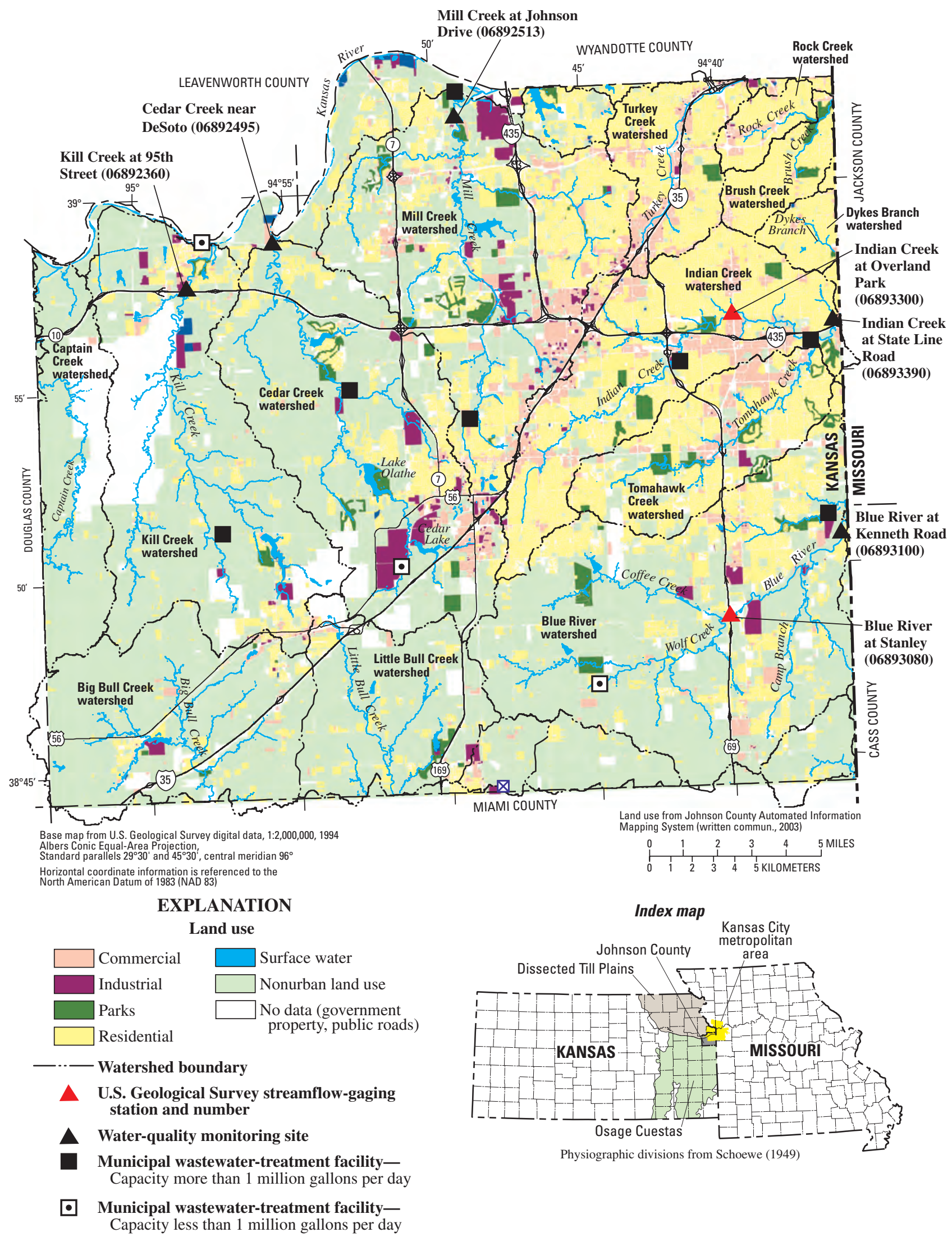

Figure 1. Location of monitoring sites, watershed boundaries, and land use, Johnson County, northeast Kansas. 


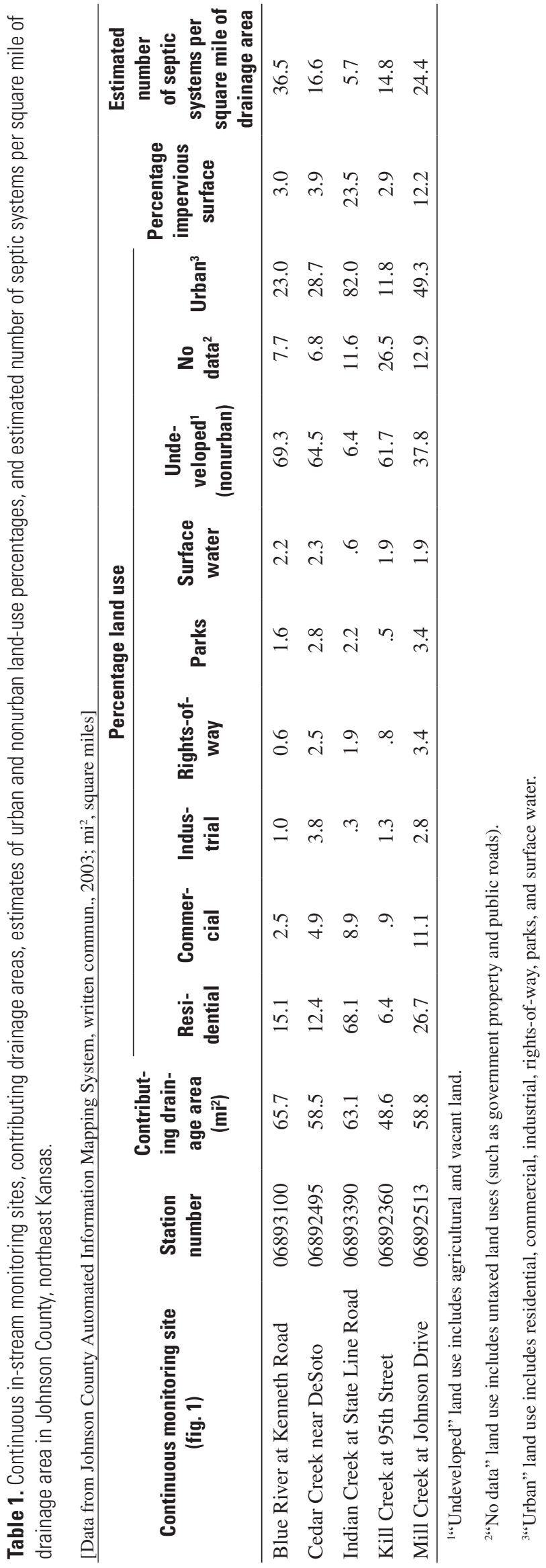


Table 2. Watersheds containing stream segments with 303(d) listings and total maximum daily loads (TMDLs) completed or being developed, Johnson County, northeast Kansas, 2006.

[Data from Kansas Department of Health and Environment, 2006a; X, Section 303(d) listing and total maximum daily load developed; --, no total maximum daily load]

\begin{tabular}{|c|c|c|c|c|c|c|c|c|c|}
\hline \multirow[b]{2}{*}{$\begin{array}{l}\text { Watershed } \\
\text { (fig. 1) }\end{array}$} & \multicolumn{9}{|c|}{ 303(d) listing and TMDLs } \\
\hline & Biology & $\begin{array}{c}\text { Dissolved } \\
\text { oxygen }\end{array}$ & Chloride & Chlordane $^{1}$ & $\begin{array}{l}\text { Fecal } \\
\text { coliform } \\
\text { bacteria }\end{array}$ & Mercury & Nitrates & $\begin{array}{c}\text { Nutrients/ } \\
\text { biological } \\
\text { oxygen } \\
\text { demand }\end{array}$ & $\begin{array}{l}\text { Sediment } \\
\text { impact on } \\
\text { aquatic } \\
\text { life }^{3}\end{array}$ \\
\hline Blue River & -- & $\mathrm{X}^{2}$ & -- & $X$ & $X$ & $\mathrm{X}^{1,2}$ & -- & $\mathrm{X}$ & -- \\
\hline Cedar Creek & -- & -- & -- & -- & $\mathrm{X}$ & -- & $X$ & -- & -- \\
\hline Indian Creek & -- & -- & -- & -- & $\mathrm{X}$ & -- & $\mathrm{X}^{2}$ & -- & -- \\
\hline Kill Creek & -- & -- & -- & $\mathrm{X}$ & $\mathrm{X}$ & -- & -- & -- & -- \\
\hline Mill Creek & $\mathrm{X}$ & -- & $\mathrm{X}$ & -- & $\mathrm{X}$ & -- & -- & $\mathrm{X}$ & $\mathrm{X}$ \\
\hline
\end{tabular}

${ }^{1}$ Impairment identified by fish-tissue analysis.

${ }^{2}$ TMDLs scheduled to be developed in 2006-08.

${ }^{3}$ Impairment identified by biological monitoring.

turbidity, and dissolved oxygen were monitored continuously in the five watersheds between October 2002 and December 2006. The continuous information was used in conjunction with discrete water samples collected from October 2002 through January 2006 to develop regression models for estimating selected constituent concentrations, loads, and yields. Continuous regression-based concentrations were estimated for suspended sediment, total suspended solids, dissolved solids, major ions, nutrients (nitrogen and phosphorus species), and fecal-indicator bacteria. Continuous daily, monthly, seasonal, and annual loads and yields were calculated using concentration estimates and streamflow. Relations between streamflow and turbidity are described to help infer sources of sediment in streams. In addition, results of discrete samples analyzed for pesticides are presented.

The results presented in this report may be used to better understand concentration and load fluctuations during changing seasonal and streamflow conditions and to assess waterquality conditions relative to TMDLs, NPDES requirements, and water-quality standards. With long-term operation, the information could be useful for evaluating loading characteristics such as range and variability of selected water-quality constituents, for describing the relation of loading characteristics to land use and basin characteristics, and for evaluating the effectiveness of implemented BMPs.

\section{Description of Study Area}

Johnson County, Kansas consists of $477 \mathrm{mi}^{2}$ of surface area located in the western part of the Kansas City metropolitan area (U.S. Census Bureau, 2007). The five largest watersheds in Johnson County (fig. 1) comprise 73 percent of the total land area in the county and are the focus of this report. Designated uses for streams within the county include support of aquatic life, contact recreation, drinking-water supply, food procurement, ground-water recharge, irrigation, industrial use, and livestock watering (Kansas Department of Health and Environment, 2006a).

Physiographic regions of Johnson County include the Osage Cuestas in the central and southern parts of the county and the Dissected Till Plains along the northern part of the county (fig. 1) (Schoewe, 1949). The county is underlain by sedimentary rock characterized by alternating layers of limestone and shale and smaller amounts of fine-grained sandstone. Soils consist primarily of loess, glacial deposits, and residual from the weathering of bedrock (Plinsky and others, 1975). Johnson County streams that flow north into the Kansas River such as Kill, Cedar, and Mill Creeks have steeper gradients than those flowing east such as Indian Creek and the Blue River (O'Connor, 1971).

The climate of Johnson County is classified as humid continental, characterized by variable weather patterns and large temperature ranges (Ritter, 2006). The mean annual temperature of the study area is about $55^{\circ} \mathrm{F}$, with a mean monthly range from $28^{\circ} \mathrm{F}$ in January to $78^{\circ} \mathrm{F}$ in July (National Oceanic and Atmospheric Administration, 1966-98). Mean annual precipitation (1961-90) is about $40 \mathrm{in}$., with 68 percent of the rain occurring during the growing season from April through September (National Oceanic and Atmospheric Administration, 1966-98).

Population increases in Johnson County have resulted in increased urban and suburban land uses. From 1990 to 2004, land parcels dedicated to residential and commercial land use in Johnson County have increased more than 45 percent (K. Skridulis, Johnson County Appraiser's Office, written commun., 2004). Figure 1 shows urban and nonurban land use for Johnson County in 2003 (S. Porter, Automated Information Mapping System, written commun., 2003). The northeastern part of the county including the Brush Creek, Dykes Branch, 
Indian Creek, Rock Creek, Tomahawk Creek, and Turkey Creek watersheds contain most of the urban development with more than 75 percent of the watershed areas devoted to residential, commercial, industrial, and rights-of-way land uses. More than 18 percent of these watersheds are overlain by impervious surface. New urban developments primarily are focused in the Blue River and Mill Creek watersheds (MidAmerica Regional Council, 2002).

Ten municipal wastewater-treatment facilities (WWTFs) are located within the monitored watersheds, seven of which have a design discharge capacity of more than 1 million gallons per day (Mgal/d) (fig. 1). The largest wastewater discharges occur in the Indian Creek watershed where two WWTFs with a combined design flow capacity of $22 \mathrm{Mgal} / \mathrm{d}$ discharge upstream from the monitoring site. The major WWTF in the Blue River watershed, which has a design flow capacity of $10.5 \mathrm{Mgal} / \mathrm{d}$, discharges downstream from the monitoring site. The remaining three WWTFs in the monitored Cedar, Kill, and Mill Creek watersheds have design flow capacities ranging from 2.5 to $3.2 \mathrm{Mgal} / \mathrm{d}$. Generally, WWTF effluent can affect water quality and biological communities of receiving streams by increasing oxygen-demanding substances such as organic matter and ammonia, which then reduce oxygen available to aquatic life and release excessive amounts of nutrients (such as carbon, nitrogen, and phosphorus), pathogens, and organic chemicals, altering stream-water temperature (U.S. Environmental Protection Agency, 2004b).

\section{Previous Studies}

Although a comprehensive study of Johnson County streams had not been conducted prior to 2002 when the current investigation began, studies of several streams and lakes within individual watersheds have been conducted. A study of Indian and Rock Creeks in 1981-82 (Mid-America Regional Council and F.X. Browne and Associates, Inc., 1983) found that commercial and industrial areas had increased nitrogen and metal concentrations, suspended-sediment concentrations were much larger during stormflow and likely originated from exposed soils and steep channel slopes, and some contaminants including phosphorus, manganese, and iron were associated with suspended sediment. A study of Lake Olathe in the Cedar Creek watershed (Mau and others, 2004) found nutrient yields consistent with mixed agricultural watersheds and atrazine concentrations that occasionally exceeded KDHE chronic aquatic-life criterion of $3.0 \mu \mathrm{g} / \mathrm{L}$ during spring and summer. A study of Big Bull and Little Bull Creeks found that during base flow the largest total nitrogen and phosphorus concentrations occurred downstream from wastewater discharges (Putnam, 1997).

Studies also have characterized water quality in the Blue River Basin in Kansas and Missouri. Indian Creek flows into the Blue River downstream from Johnson County and is, therefore, considered part of the Blue River Basin. Blevins (1986) recorded larger stormwater runoff per unit area for urban sites than for nonurban sites and smaller concentrations of suspended sediment, nutrients, and metals in concrete channels. During 1998-2000, the nearly continuous discharge of treated wastewater effluent was found to be a primary source of nutrients, wastewater compounds, and pharmaceutical compounds in the Blue River and Indian Creek (Wilkison and others, 2002). The same study found that overflow of combined storm and sanitary sewers triggered by stormflow contributed untreated wastewater into Brush Creek which feeds into the Blue River. In a followup study of the Blue River Basin, Indian Creek was found to contribute about 60 percent of total nitrogen and phosphorus loads to the Blue River in Missouri (Wilkison and others, 2005, 2006). In addition, bacteria in streams originated primarily from nonpoint sources during storm runoff (Wilkison and others, 2006).

Lee and others (2005) used water- and sediment-quality analysis from samples collected in multiple Johnson County watersheds from October 2002 through June 2004 to describe the effects of point and nonpoint contaminant sources on Johnson County streams. The study found that during baseflow conditions, discharge from wastewater-treatment facilities (WWTFs) comprised greater than 50 percent of total streamflow at the farthest downstream sampling sites in six of seven basins. Also during base-flow conditions, nutrients, organic wastewater-indicator compounds, and pharmaceutical compounds generally were found in the largest concentrations at sites at, or immediately downstream from, WWTF discharges. Nutrients, silver, and many wastewater-indicator and pharmaceutical compounds had the largest concentrations in streambed-sediment samples collected immediately downstream from WWTFs. Generally, sites upstream from WWTFs had significantly larger fecal-indicator bacteria densities than sites downstream during base-flow conditions, indicating WWTFs were not a major source of bacteria during base flow. The largest suspended-sediment concentrations and indicator-bacteria densities occurred during storm runoff. In addition, stormflow samples had the largest nutrient concentrations with the exception of samples collected immediately downstream from WWTFs. Trace elements, chlordane, total dichloro-diphenyltrichloroethane (DDT), polyaromatic hydrocarbons (PAHs), and some wastewater-indicator compounds had the largest concentrations in streambed sediment from watersheds with predominantly urban land use.

A recent biological assessment of Johnson County streams found that as urbanization increased, biological condition generally decreased, and stream conditions at the most urbanized sites were nonsupportive of aquatic life on the basis of State criteria (Poulton and others, 2007). In addition, upstream sites on the Blue River and Cedar and Kill Creeks were minimally affected by human disturbance, and Johnson County sites on Indian, Tomahawk, and Turkey Creeks and Missouri sites in downstream reaches of the Blue River and Brush Creek were most affected by human disturbance (Poulton and others, 2007). 


\section{Methods}

\section{Data Collection and Analysis}

Continuous water-quality monitors (fig. 2) and streamflow-gaging stations were installed on five streams in Johnson County (fig. 1, table 1). Monitoring sites were located as far downstream as possible in the largest watersheds in the county and represented urban, urbanizing, and nonurban land uses.

\section{(A) Kill Creek at 95th Street}

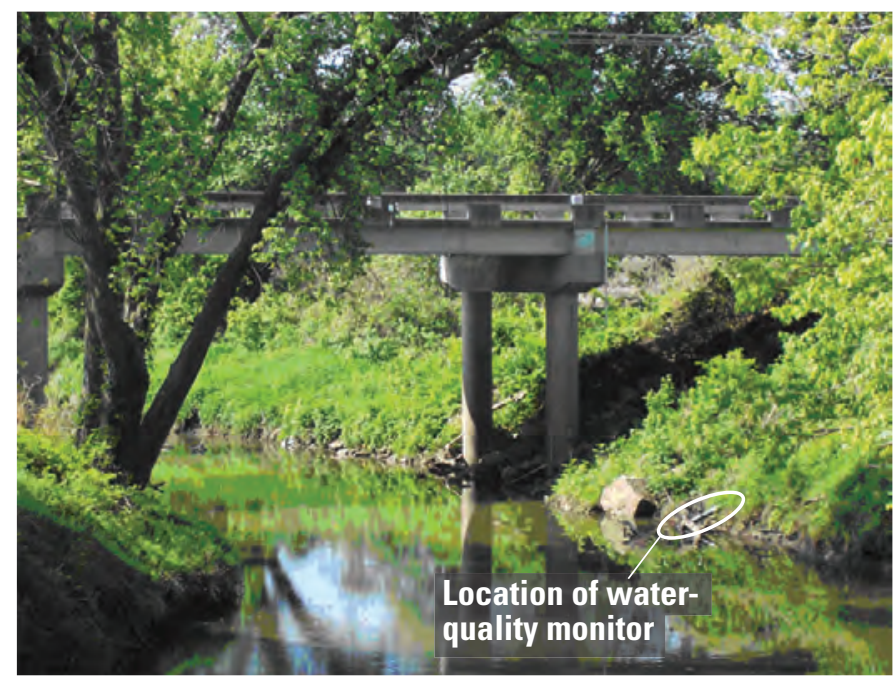

(B) Continuous water-quality monitor

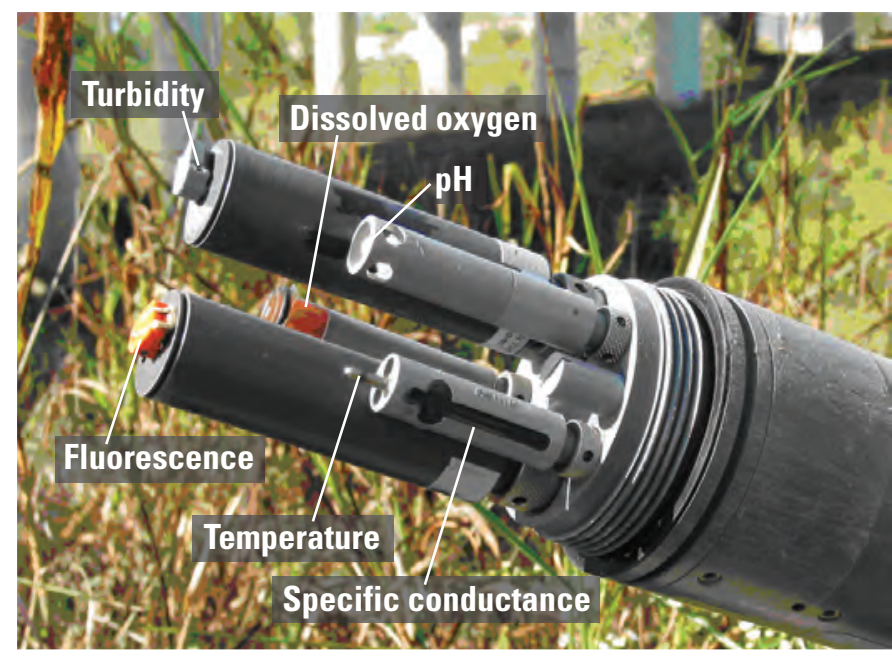

Figure 2. (A) Kill Creek at 95th Street (station 06892360), one of five continuous water-quality monitoring sites in Johnson County, Kansas. The water-quality monitor is placed beneath the water surface next to the streambank. (B) Monitor used to measure continuous, in-stream specific conductance, pH, water temperature, turbidity, and dissolved oxygen. A fluorescence sensor is pictured, but fluorescence was not monitored continuously during this study.
Streamflow was measured using methods presented in Buchanan and Somers (1969) and Oberg and others (2005). Each site was equipped with a water-quality monitor that provided continuous (every 5 or 15 minutes) in-stream measurements of specific conductance, $\mathrm{pH}$, water temperature, turbidity, and dissolved oxygen (DO). Hourly values (values measured at 1:00 am, 2:00 am, 3:00 am, and so forth) were used for data analysis and interpretation in this report. These data are available in real time on USGS Web pages (http:// ks.water.usgs. gov/Kansas/rtqw/ and http://waterdata.usgs.gov/ks/nwis/). Monitor maintenance and data reporting followed standard procedures described in Wagner and others $(2000,2006)$. Two of the sites, Cedar Creek near DeSoto (station 06892495, fig. 1) and Mill Creek at Johnson Drive (station 06892513), were installed in October 2002, and three sites, Blue River at Kenneth Road (station 06893100), Indian Creek at State Line Road (station 06893390), and Kill Creek at 95th Street (station 06892360), were installed in March 2004. Results are presented for all sites through December 2006.

Continuous in-stream sensor data were compared to average cross-section data at the monitor location to verify that the continuous data were representative of conditions across the width of the stream. A total of 126 cross-section measurements were made with an independent water-quality monitor during various hydrologic conditions at the five monitoring sites. Each measurement consisted of about 10 readings within the cross-section. Relative percentage differences (RPDs) were calculated between the cross-section median for each constituent (specific conductance, $\mathrm{pH}$, water temperature, turbidity, and DO) and the concurrent continuous-monitor reading. Median values were used because the mean was affected by extreme readings that occurred most often on the far right or left streambank where zero or low-velocity water was present (and therefore were not representative of flow conditions).

Monitor placement did not result in a consistent bias for any constituents measured at any of the water-quality cross sections. The median value of all 126 RPDs (which compared cross-section median to continuous-monitor reading) was less than 1 percent for each constituent at each station. Several continuous-monitor readings had more than a 10-percent difference between cross-section median values. Six turbidity values were more than 10-percent different from cross-section medians. All of these differences occurred at sites in which the monitor was installed on the right or left streambank rather than near the center of flow. The largest RPD for turbidity was 38 percent and occurred at the Kill Creek site. One specific conductance value was more than 10 percent different ( 45 percent at Indian Creek), likely because of highway drainage pipes contributing road-salt affected runoff near the right bank where the monitor is located.

The quality of the continuous monitoring data during the study period generally was good according to guidelines described by Wagner and others (2006). Quality of in-stream sensor data was determined primarily by evaluating sensor readings during routine calibration verification procedures. Each monitor was serviced a minimum of 15 times annually 
for routine cleaning and calibration purposes. If the majority of the cleaning and calibration measurements were less than 10 percent different from the expected (cleaned and calibrated) value, the data quality was considered good. If the measurements differed by 10-15 percent, the data quality was considered fair. If the measurements differed by 15-30 percent, the data quality was considered poor. Data that differed by more than 30 percent were deleted from the dataset. Specific conductance, $\mathrm{pH}$, and water temperature datasets were nearly always good. Turbidity data usually were good but occasionally fair. DO datasets were usually fair. The final data for all sensors were corrected to ensure accuracy as described by Wagner and others (2006). Annual datasets for in-stream sensor measurements were 90-100 percent complete except for DO at the Indian Creek site in 2006, which was 85 percent complete. More DO data were missing from the final dataset during 2006 because fouling of the sensor was more common during that time period, resulting in removal of more measurements that did not meet verification criteria described in the guidelines.

In addition to continuous monitoring, discrete water samples were manually collected from each site according to either the equal depth integrated (EDI) method or the equal width integrated (EWI) method described by Wilde and others (1999) or using automated samplers. Sample collection also followed methods described by Edwards and Glysson (1999) for collecting representative samples to be analyzed for suspended sediment and other water-quality constituents. Samples to be analyzed for dissolved constituents were filtered using 0.45 micron filters, and samples to be analyzed for total constituents were not filtered. Sample collection began when monitors were installed and continued through December 2006. At each site, 18 to 28 samples were collected between October 1, 2002 and January 31, 2006 during various runoff conditions. About 90 percent of these samples were collected following width- and depth-integrated sampling methods, and the rest were collected using automated samplers. EDI and EWI sample collection, which results in integrated samples that are representative of the entire width and depth of the stream cross section, were generally the preferred sampling methods in this study. However, automated samplers also were used because storm runoff in small, urban basins often results in rapidly rising and falling streamflow peaks that can be difficult to capture with manual samples.

Because of the potential differences associated with sampling methods, 17 automated samples were collected as near in time as possible with integrated suspended-sediment samples to evaluate variability between the sampling methods (fig. 3). Results indicated that sediment samples collected using automated samplers differed from samples collected using integrated methods by an average of 28 percent (fig. 3). Differences occurred because automated samplers collect samples from a single point rather than a complete depth-integrated cross section and because varying pumping speed and stream

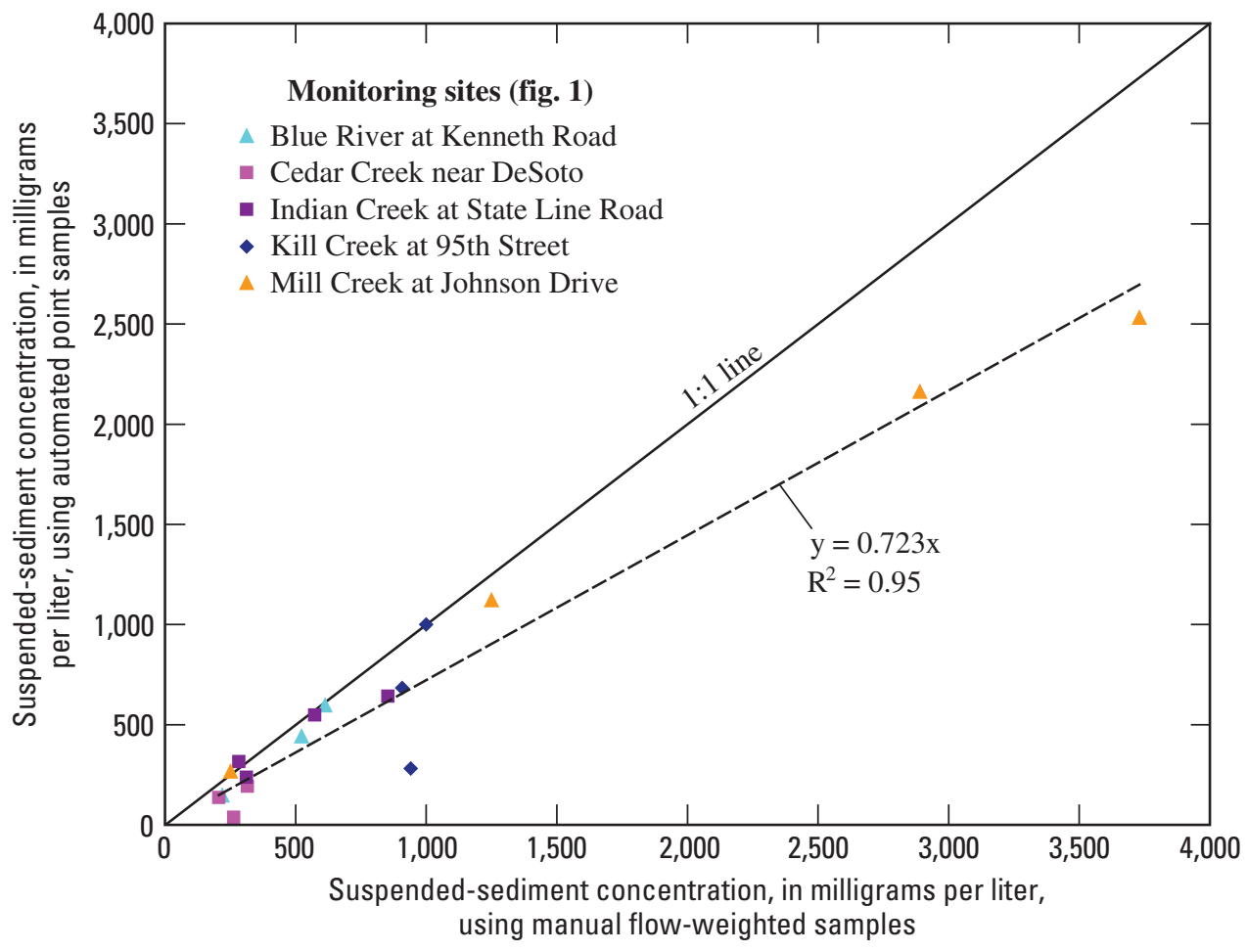

Figure 3. Comparison between suspended-sediment concentrations in samples collected using manual flow-weighted sampling methods and automated samplers at five monitoring sites in Johnson County, Kansas, 2003-06. 
velocity prevent the automated samplers from collecting isokinetic (equal flow) samples as is done with EDI and EWI methods. Other factors contributing to the difference include rapidly changing streamflow and sediment conditions (for example, an automated sample is collected from a fixed point usually within 15 minutes, and an EDI or EWI sample may require as much as an hour to collect) and lack of adequate lift from pumps to carry large amounts of suspended sediment from stream to samplers.

Samples were analyzed for nutrients, indicator bacteria, sediment, and other constituents. Data qualified by the analyzing laboratory as "estimated" (for example, bacteria in the "nonideal" count range as defined by the analytical method protocol) were treated the same as unqualified data. These discrete samples, including all samples regardless of collection method (EDI, EWI, automated sampler), were collected throughout the range of streamflow and sensor conditions recorded at each site. The discrete samples that were collected represented about 95 percent of the range in flow conditions for the site and represented rising, falling, peak, and base streamflow conditions.

Discrete quality-control samples, including blank and replicate samples, were collected and analyzed to assess variability among samples resulting from collection, processing, shipping, and laboratory procedures conducted at different sampling times (Wilde and others, 1999). Equipment blank samples were collected to measure a combination of the potential contamination from the equipment used in sample collection and environmental conditions in the laboratory. Rinse blank samples were collected to measure the effectiveness of equipment cleaning protocols and replicate samples were collected to evaluate laboratory and subsample bias and precision.

Water samples were analyzed at several laboratories. Major ions and nutrients were analyzed at the Johnson County Environmental Laboratory in Johnson County, Kansas, according to standard methods (American Public Health Association and others, 1995). Selected dissolved pesticides and replicate samples for major ions and nutrients were analyzed by the USGS National Water-Quality Laboratory (NWQL) in Denver, Colorado, according to methods presented in Fishman and Friedman (1989), Faires (1993), Fishman (1993), and Zaugg and others (1995). Suspended-sediment samples were analyzed by the USGS Sediment Laboratory in Iowa City, Iowa, according to methods presented in Guy (1969). Analysis of indicator bacteria (E. coli, fecal coliform, and enterococci) was done at the USGS laboratory in Lawrence, Kansas. The bacteria samples were processed within 6 hours of collection using membrane filtration methods described by Wilde and Radtke (1998). Although both USGS and Johnson County laboratories analyzed all three types of fecal indicator bacteria for most samples, results from USGS were used as the primary data source. Values reported by a laboratory as estimated occurred when data quantification deviated in any way from standard procedures. Tables containing additional constituents analyzed and laboratory reporting levels are provided in Lee and others (2005).
Results of blank and replicate sample analysis are included in table 3. The median RPD between replicate pairs was less than 10 percent for all constituents except some nutrient species and indicator bacterias. Analysis for most of the replicate samples involved analysis of the same sample set by the two different laboratories. For acid neutralizing capacity, dissolved solids, E. coli bacteria, and enterococci bacteria, comparison information applies to different laboratory methods used by the USGS and Johnson County laboratories. Both laboratories analyzed sulfate, silica, ammonia, and manganese for most samples because of method differences, resulting in more replicate pairs for these constituents than the other constituents except indicator bacteria (table 3). Pesticide compounds were not detected in blank samples. RPDs for pesticides when detectable concentrations were reported were less than 20 percent. Generally for all constituents, but especially for the nutrient species, larger RPDs occurred when values were near the reporting level. In addition, variability in indicator bacteria data may be caused by rapidly changing conditions during storm runoff making it difficult to collect samples with comparable bacteria densities.

\section{Regression Models}

Ordinary least squares (OLS) regression analysis was used to develop relations between the continuous sensor measurements, streamflow, time, and discretely sampled constituent concentrations (Helsel and Hirsch, 2002; Christensen and others, 2000). Discrete sample data used in regression analysis included EDI, EWI, and automated samples collected from October 2002 through January 2006. Site-specific regression models were developed using an overall modelbuilding approach (Helsel and Hirsch, 2002) that included plotting each possible explanatory (independent) variable against the response (dependent) variable and visually and statistically examining the residual plots for patterns. For each response variable, all continuously measured variables (streamflow, specific conductance, $\mathrm{pH}$, water temperature, turbidity, and dissolved oxygen) were tested for significance. In addition, seasonal patterns in data were tested for significance by using sine and cosine terms as possible explanatory variables (Helsel and Hirsch, 2002). Explanatory and response variables (except time) were log transformed if necessary to normalize datasets to satisfy statistical assumptions, prior to developing the linear relation. Many data transformations and all possible regression equations were evaluated. Generally, if there were several acceptable models (F-test p-value less than 0.05), the one with the smallest prediction error sum of squares (PRESS) statistic was selected. The PRESS statistic is a measure of goodness of fit of a regression model (Helsel and Hirsch, 2002). Explanatory variables were included in a model only if there was a physical basis for their inclusion.

For statistical analysis, when concentrations were reported as less than the laboratory reporting level, they were assumed to be one-half the reporting level. Uncertainties 
Table 3. Water-quality constituents, units of measurement, laboratory reporting levels, and results of replicate stream sample and blank sample analysis for five water-quality monitoring sites in Johnson County, northeast Kansas, October 2002 through December 2006.

$[R P D$, relative percentage difference; $\mathrm{mg} / \mathrm{L}$, milligrams per liter; $<$, less than; $\mu \mathrm{g} / \mathrm{L}$, micrograms per liter; col/100 mL, colonies per $100 \mathrm{milliliters} \mathrm{of} \mathrm{water;}$ ,-- not detected]

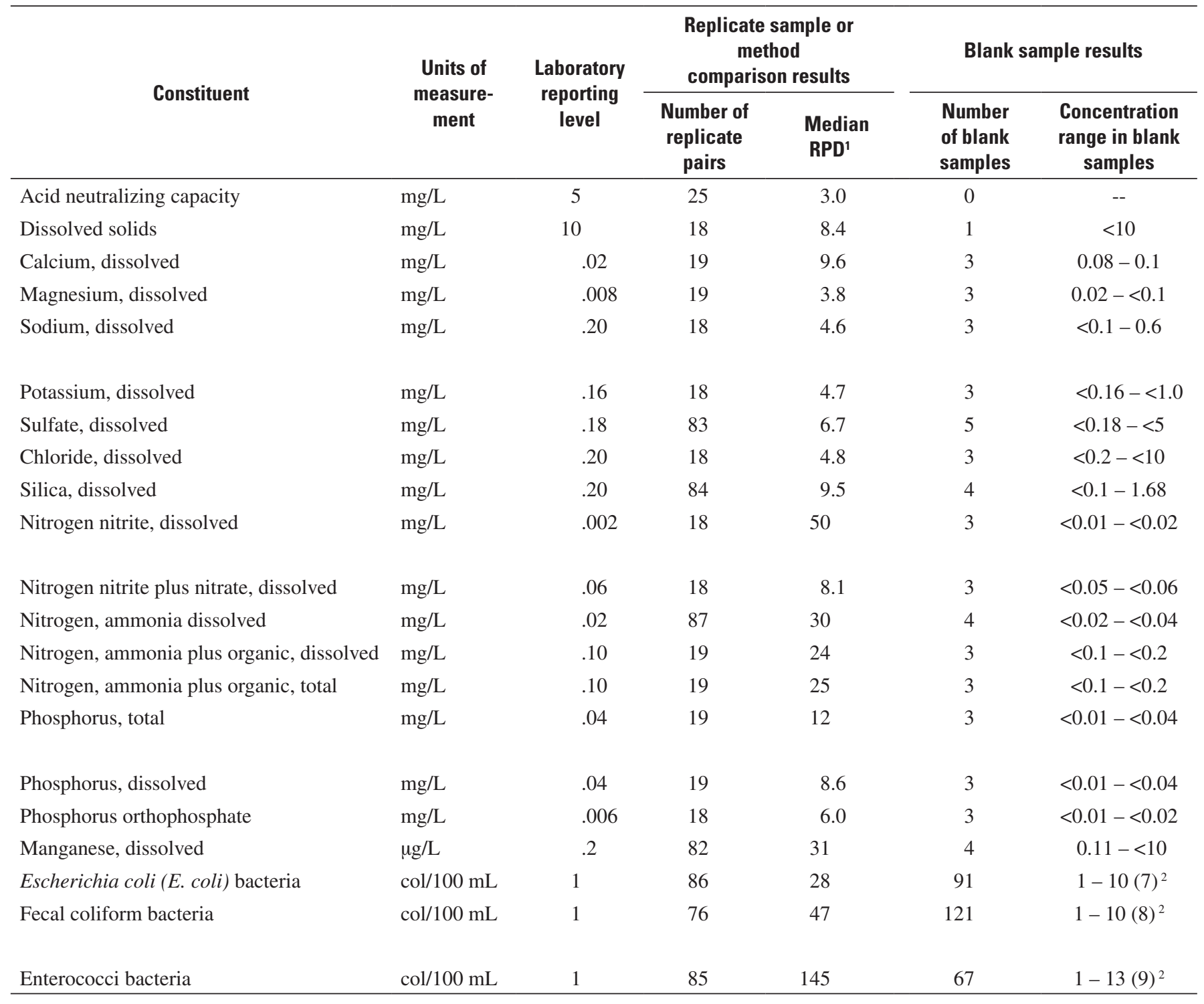

${ }^{1} R P D=\left[|A-B| /\left(\frac{A+B}{2}\right)\right] \times 100$, where $A$ and $B$ are concentrations in each replicate pair.

${ }^{2}$ Numbers indicate range in number of bacteria colonies. Number in parentheses ( ) indicates number of blank samples with bacteria colonies.

associated with each model were evaluated on the basis of diagnostic statistics ( $\mathrm{R}^{2}$, coefficient of determination; RMSE, root mean square error), patterns in residual plots, and the range and distribution of discrete (EDI, EWI, and automated) samples and continuous data.

Uncertainty for each estimate from regression models was calculated using 90-percent prediction intervals (Helsel and Hirsch, 2002). Probabilities of exceeding water-quality standards, recommended criteria, or guidelines of the State of Kansas and USEPA also were calculated (Rasmussen and Ziegler, 2003; Francy and Darner, 2006). Regression methods used in this study are described in greater detail in Cohn and others (1989), Hirsch and others (1993), Helsel and Hirsch (2002), and Rasmussen and Ziegler (2003). Duration (frequency of exceedance) curves were constructed to display and help characterize the frequency, duration, and magnitude of water-quality variability. When OLS regression is used to generate estimates for which probability statements are made, such as with duration curves and probability of exceeding criteria, values at the upper end likely are underestimated and values at the lower end may be overestimated (Helsel and Hirsch, 2002). The continuous concentration and load 


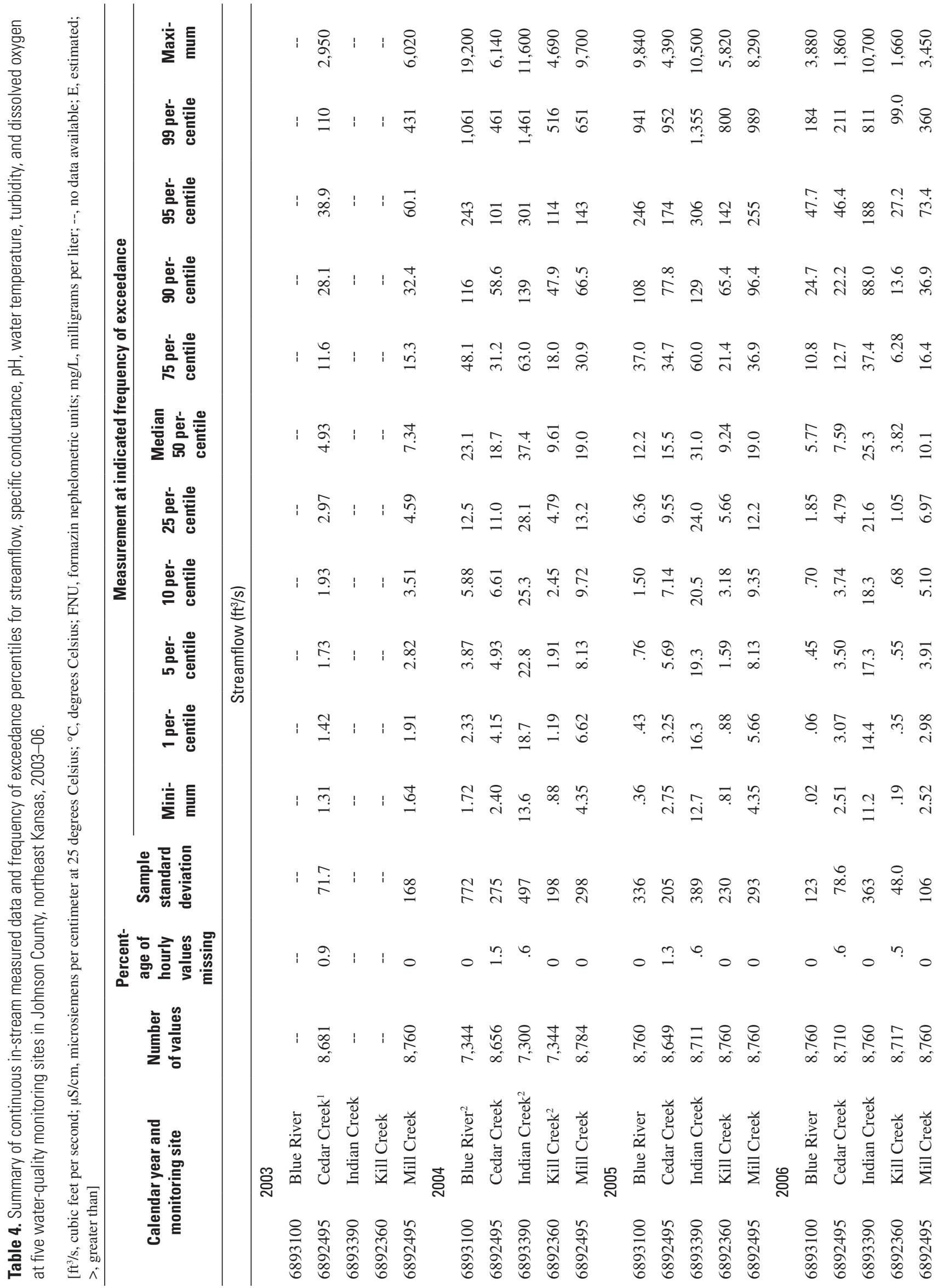




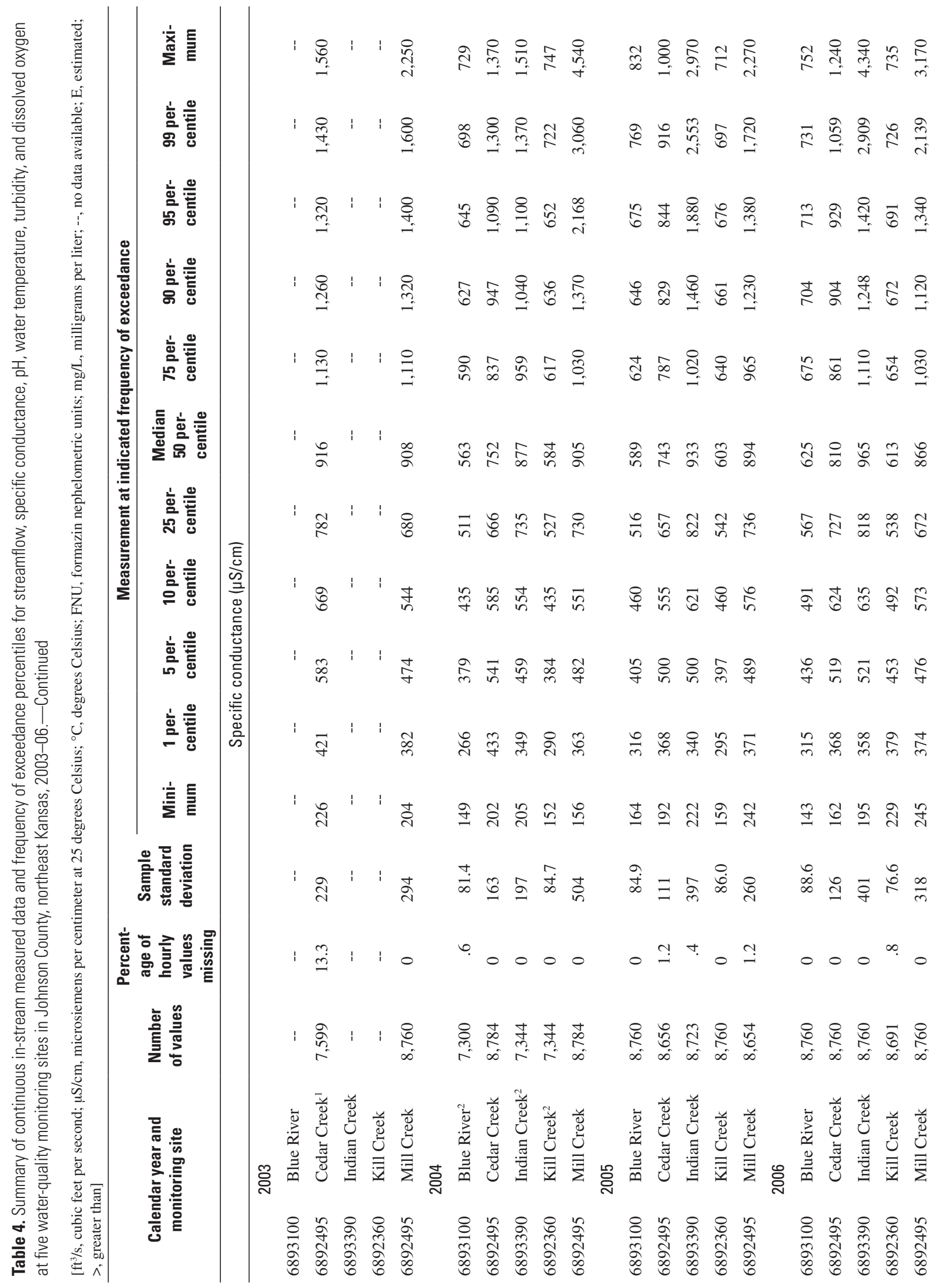




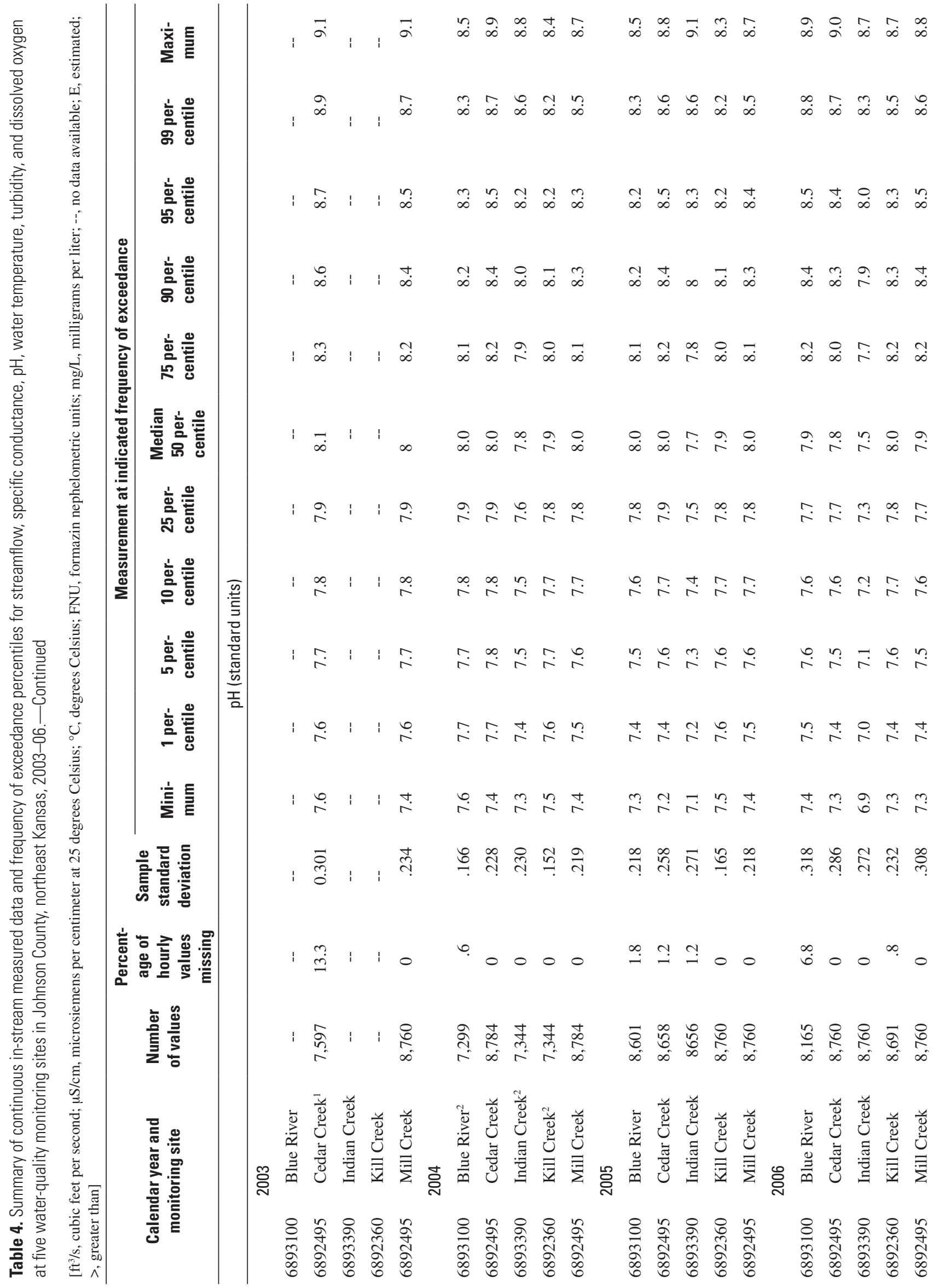




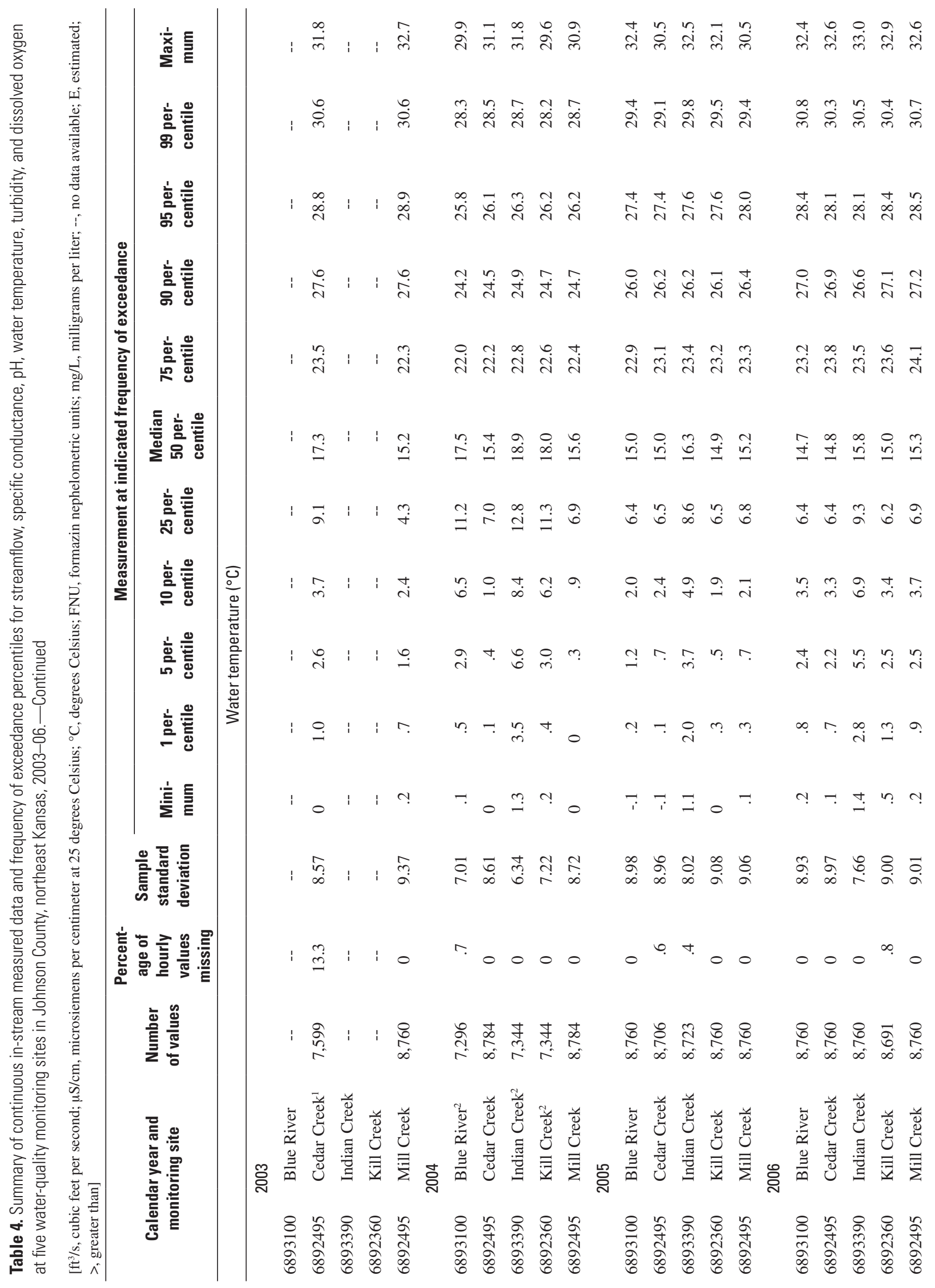




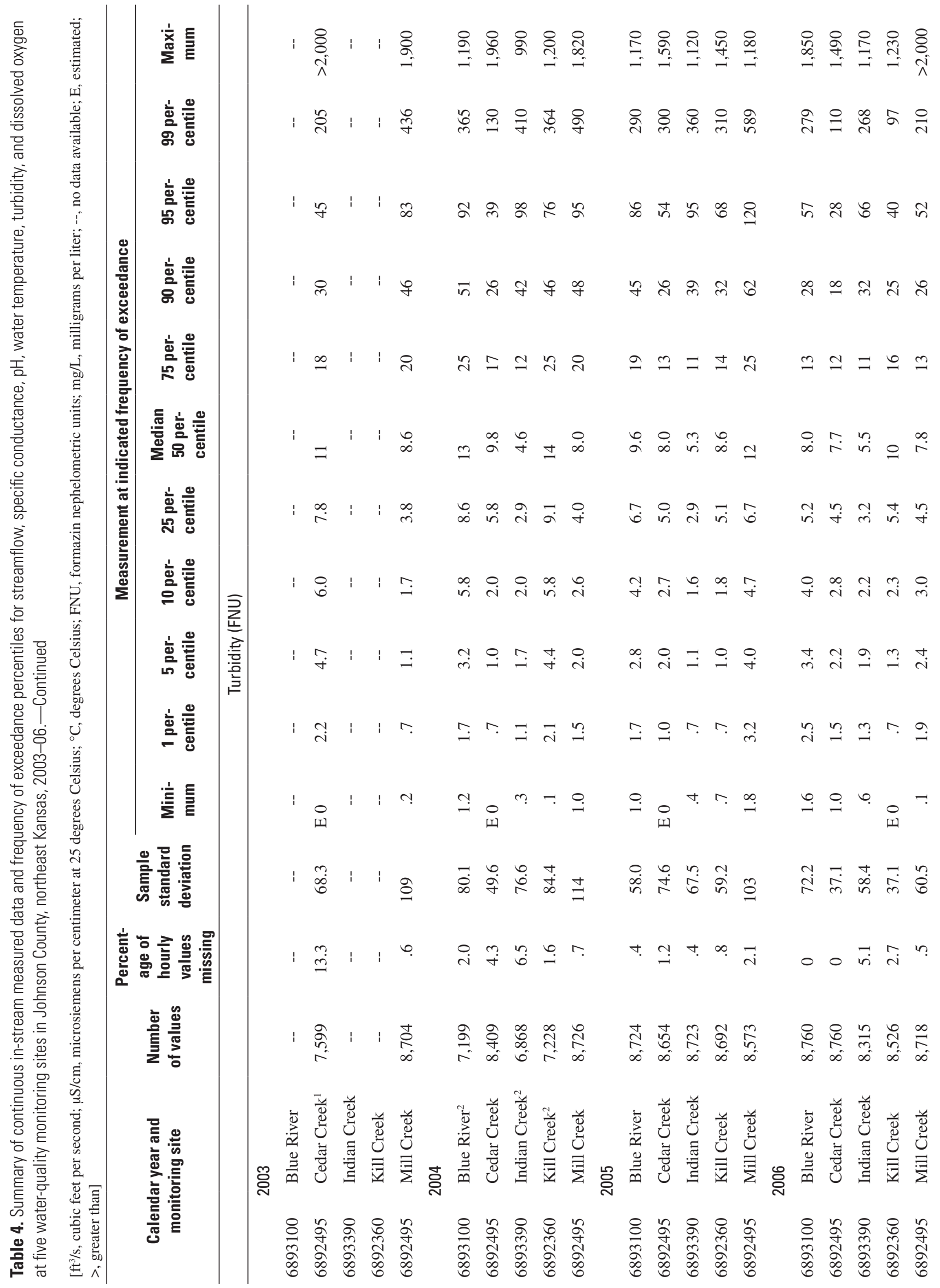




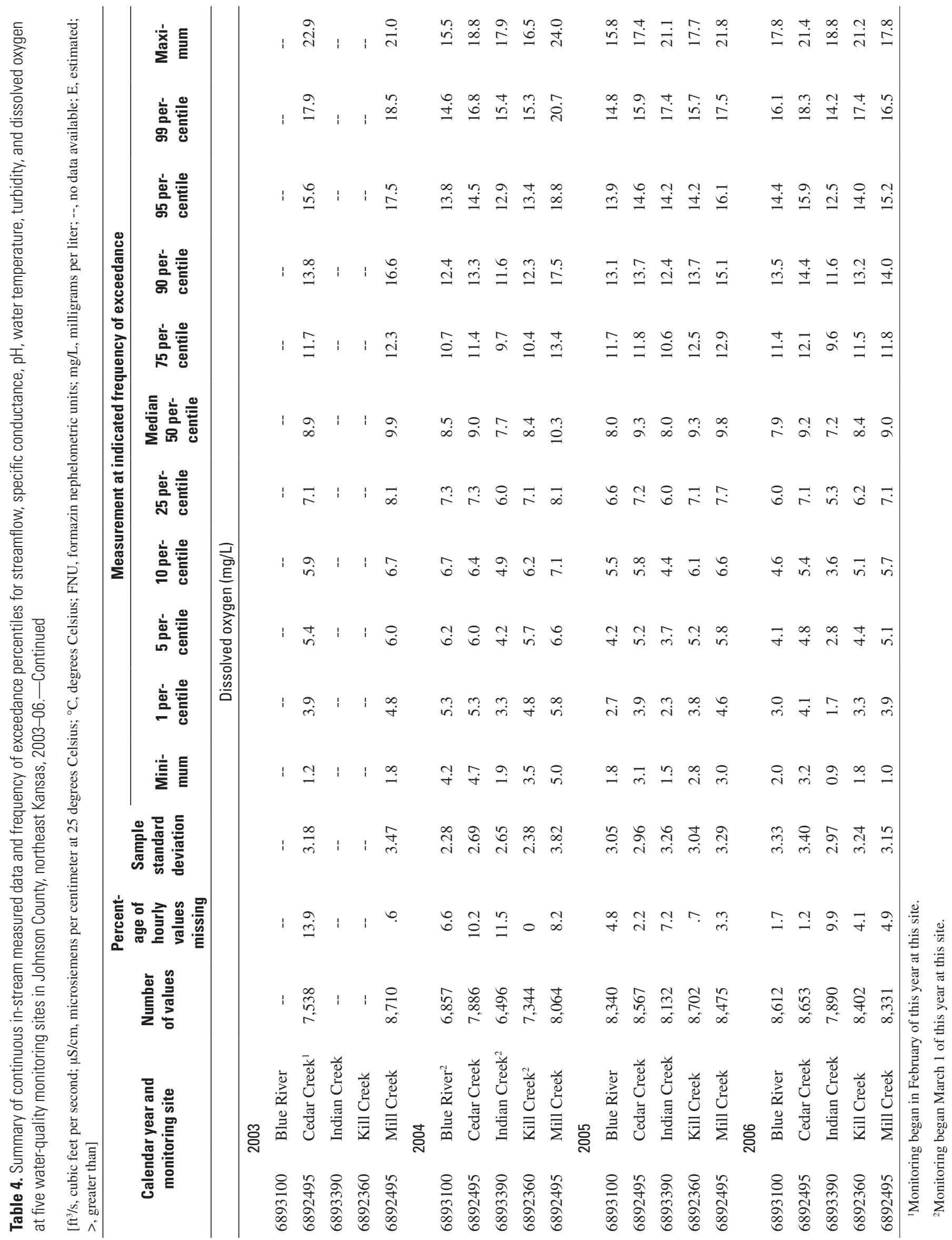


estimates, probability, uncertainty, and duration curves for the five monitoring sites are available on the World Wide Web at http://ks.water.usgs.gov/Kansas/rtqw.

Several factors can contribute to variability in the regression models. These factors include equipment limitations associated with obtaining accurate measurements, variability in sample collection, processing, and analysis, and unmixed or rapidly changing stream conditions.

\section{Estimation of Constituent Concentrations, Densities, Loads, and Yields}

Continuous (hourly) constituent concentrations and loads were estimated using the regression models. In this report, in-stream and estimated continuous concentration data were evaluated from March 2004 through December 2006 when all five monitoring sites were operating simultaneously. Estimated load and yield data were evaluated for 2005 and 2006, the two full calendar years when all five monitor sites were operating. Seasonal comparisons were made by grouping the data into three periods consistent with the seasonal periods used by KDHE and determined primarily by streamflow. March through July represent the spring and early summer runoff season, August through October represent variable streamflow associated with late summer and fall, and November through February represent the winter low-flow season. Additional data are available at http://ks.water.usgs.gov/Kansas/rtqw1.

Continuous data occasionally were missing during periods when the water-quality instruments malfunctioned, extreme weather conditions occurred, or during routine maintenance visits. Generally, after initial equipment installation, less than 2 percent of the hourly values were missing from each site annually (table 4). Missing data were not estimated during these periods. In addition, a specified range of operation is associated with each sensor on the in-stream monitor. Conditions in the monitored streams remained within these specified ranges except for turbidity. Turbidity sensors used in the study (YSI model 6136, Yellow Springs Instruments, Yellow Springs, Ohio) were capable of measuring a range from less than 3 to about 2,000 formazin nephelometric units (FNUs), depending on the individual sensor. Turbidity conditions rarely exceeded the upper measurement limit during the study. Five hourly turbidity values were affected by sensor maximization at Mill Creek in 2003 and 19 hourly turbidity values were affected by sensor maximization at Kill Creek in 2004. When the actual turbidity was more than the maximum a sensor could measure, the sensor reported only the maximum value. That maximum sensor value was used to estimate the concentrations and loads.

For response variables that were log-transformed, retransformation of regression-estimated concentrations was necessary. Retransformation can cause bias (underestimation) in the estimated constituent loads when adding individual estimates over a period of time (Helsel and Hirsch, 2002). Therefore, a log-transformation bias correction factor, Duan's smearing estimator (Duan, 1983) was calculated and applied to the estimated hourly concentration values to correct for this underestimation.

Constituent loads and yields were estimated from continuous concentration estimates, continuous streamflow data, and respective drainage basin area. Hourly constituent loads were calculated for each constituent at each of the five monitoring sites by multiplying hourly estimated concentrations by hourly streamflow and a conversion factor. Seasonal and annual loads were calculated by summing hourly load estimates during the specified period of time. Constituent yields from the contributing drainage areas were calculated by dividing total loads by corresponding drainage areas to determine constituent concentration per square mile. Yields are important for comparing relative contributions of each basin.

\section{Duration Curves}

Duration curves are used to compare conditions among the five monitoring sites from March 2004 through December 2006 when monitors at all sites were operating simultaneously. Duration curves are cumulative distribution functions of all measurements (hourly values, in this report) within a specified period of time. The curves show the percentage of time specific conditions were equaled or exceeded, or the frequency of exceedance (Maidment, 1993). Historically, streamflow duration curves have been used in hydrologic studies to describe frequency and magnitude characteristics of streamflow (Searcy, 1959; Vogel and Fennessey, 1995). More recently, duration curves have been used to describe frequency and magnitude of continuous water-quality data (Rasmussen and Ziegler, 2003; Rasmussen and others, 2005). Although several similar formulas exist for calculating plotting position, the Weibull formula (Weibull, 1939; Helsel and Hirsch, 2002) was used in this study.

\section{Results of Continuous In-Stream Measurements}

\section{Streamflow}

Hourly streamflow ranged from less than $1 \mathrm{ft}^{3} / \mathrm{s}$ in Kill Creek (2004, 2005, and 2006) and the Blue River (2005 and 2006) to $19,200 \mathrm{ft}^{3} / \mathrm{s}$ in the Blue River (2004) (table 4). The largest median streamflow from March 2004 through 2006 occurred in Indian Creek (fig. 4), which is the second largest drainage basin $\left(63.1 \mathrm{mi}^{2}\right)$ and the most urban of the five monitored basins (table 1). Median annual streamflow at all sites in 2006 was about one-half of the median annual streamflow in 2005, except at the Indian Creek site where the 2006 median was only about 20 percent lower than the 2005 median (table 4). At all continuous monitoring sites except 


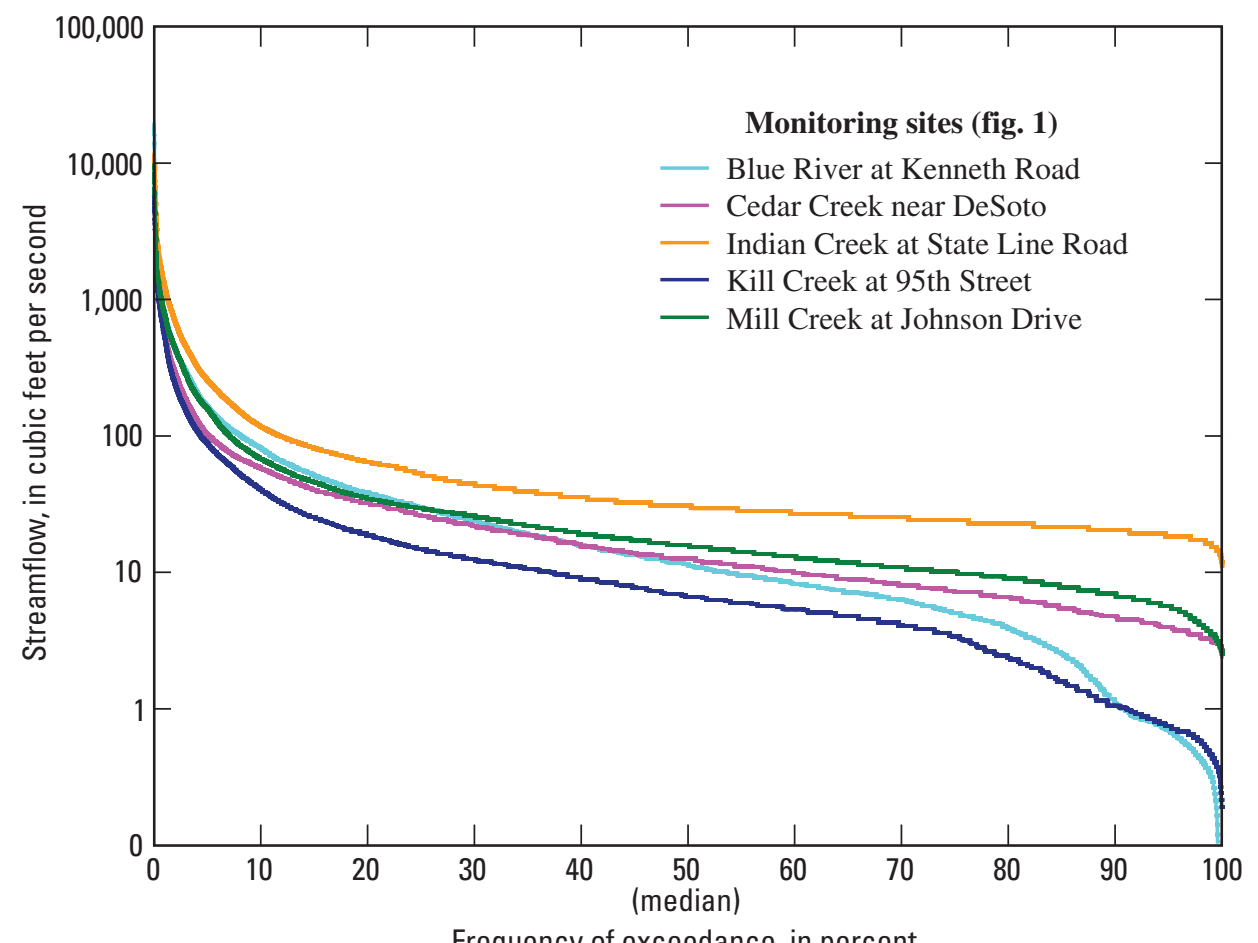

Figure 4. Duration curves for measured streamflow at five monitoring sites in Johnson County, Kansas, March 2004 through December 2006.

the Blue River, the majority of streamflow during base-flow conditions originated from WWTF discharge (Lee and others, 2005). Base flow is defined as the sustained flow of a stream in the absence of direct runoff, usually originating from ground water seepage, springs, and/or wastewater discharges. The Blue River was not affected by WWTF discharges at the monitoring site but was affected downstream from the site. The Indian Creek site was downstream from the largest magnitude of WWTF discharge received at the five monitoring sites (Lee and others, 2005), thus accounting for its larger streamflow during base-flow conditions. Kill Creek, the smallest and least urban of the monitored basins $\left(48.6 \mathrm{mi}^{2}\right.$, table 1), generally had the smallest streamflow except during minimum flows when Blue River streamflow was smallest. The Blue River, with the largest drainage area $\left(65.7 \mathrm{mi}^{2}\right.$, table 1), had the smallest streamflow during about 10 percent of the time (fig. 4) likely because of the lack of WWTF discharge at that site to sustain low flow. In 2005, 118 acre-ft of water was withdrawn from the Blue River approximately 1 to 3 mi upstream from the monitoring site for sod farm irrigation (J. Bagley, Kansas Department of Agriculture, written commun., 2006) accounting for less than 1 percent of the total annual flow volume. Streamflow volumes and yields for the five monitoring sites from 2004-06 are provided in table 5.

Historical streamflow records http://waterdata.usgs.gov ks/nwis) at two streamflow-gaging stations in Johnson County, each with periods of record of at least 30 years (Indian Creek at Overland Park, station 06893300, and Blue River at Stanley, station 06893080, fig. 1), indicated that the mean annual streamflow in 2005 was about 50 percent larger than the mean annual streamflow for the period of record. In 2006, streamflow at the Indian Creek station (06893300) was about 90 percent of the historic average streamflow and at the Blue River site (06893080) only about 40 percent of the historic average.

Annual differences in streamflow can be attributed to differences in precipitation. Average annual precipitation during the study period, calculated using the City of Overland Park's online flood-warning system "Stormwatch" (http://www. stormwatch.com) data from two to four collection sites within each watershed (depending on the number of Stormwatch sites within each watershed), indicated that annual precipitation in all watersheds was less in 2006 than in 2004 and 2005 (table 6). Average annual precipitation in 2004 and 2005 was similar to the historical mean annual precipitation of $40 \mathrm{in}$. in all five watersheds except the Blue River watershed which received 8 in. more precipitation than normal (about 48 in.) in 2004. Precipitation in 2006 was less than normal, ranging from about 28 to $34 \mathrm{in}$.

\section{Specific Conductance}

Specific conductance is a measure of water's ability to conduct an electrical current and is related to the concentration of ionized substances in water (Hem, 1992). Specific conductance is affected by soil and rock composition; size of the watershed, which affects contact with soil before runoff reaches streams; evaporation, which concentrates dissolved 
Table 5. Mean daily streamflow, annual streamflow volume, and annual streamflow yield at five water-quality monitoring sites in Johnson County, northeast Kansas, 2004-06.

[acre-ft, acre-feet; --, not available]

\begin{tabular}{|c|c|c|c|c|c|c|c|c|c|}
\hline \multirow[b]{2}{*}{$\begin{array}{l}\text { Monitoring site } \\
\text { (fig. 1) }\end{array}$} & \multicolumn{3}{|c|}{2004} & \multicolumn{3}{|c|}{2005} & \multicolumn{3}{|c|}{2006} \\
\hline & $\begin{array}{c}\text { Mean } \\
\text { daily } \\
\text { stream- } \\
\text { flow } \\
\text { (cubic } \\
\text { feet per } \\
\text { second) }\end{array}$ & $\begin{array}{c}\text { Annual } \\
\text { stream- } \\
\text { flow } \\
\text { volume } \\
\text { (acre-ft) }\end{array}$ & $\begin{array}{c}\text { Annual } \\
\text { stream- } \\
\text { flow } \\
\text { yield } \\
\text { [acre-ft/ } \\
\left.\left.\mathrm{mi}^{2}\right) / \mathrm{yr}\right]\end{array}$ & $\begin{array}{c}\text { Mean } \\
\text { daily } \\
\text { stream- } \\
\text { flow } \\
\text { (cubic } \\
\text { feet per } \\
\text { second) }\end{array}$ & $\begin{array}{c}\text { Annual } \\
\text { stream- } \\
\text { flow } \\
\text { volume } \\
\text { (acre-ft) }\end{array}$ & $\begin{array}{c}\text { Annual } \\
\text { stream- } \\
\text { flow yield } \\
\text { [acre-ft/ } \\
\left.\left.\mathrm{mi}^{2}\right) / \mathrm{yr}\right]\end{array}$ & $\begin{array}{c}\text { Mean } \\
\text { daily } \\
\text { stream- } \\
\text { flow } \\
\text { (cubic } \\
\text { feet per } \\
\text { second) }\end{array}$ & $\begin{array}{c}\text { Annual } \\
\text { stream- } \\
\text { flow } \\
\text { volume } \\
\text { (acre-ft) }\end{array}$ & $\begin{array}{c}\text { Annual } \\
\text { stream- } \\
\text { flow } \\
\text { yield } \\
\text { [acre-ft/ } \\
\left.\left.\mathrm{mi}^{2}\right) / \mathrm{yr}\right]\end{array}$ \\
\hline Cedar Creek near DeSoto & 51.2 & 37,100 & 634 & 56.1 & 40,600 & 694 & 18.5 & 13,400 & 229 \\
\hline $\begin{array}{l}\text { Indian Creek at State Line } \\
\text { Road }\end{array}$ & -- & -- & -- & 99.4 & 72,000 & 1,140 & 71.6 & 51,800 & 821 \\
\hline Kill Creek at 95th Street & -- & -- & -- & 48.1 & 34,800 & 717 & 9.5 & 6,880 & 142 \\
\hline
\end{tabular}

solids; and contaminant sources, including agricultural and urban runoff (Hem, 1966; Jordan and Stamer, 1995). In most Kansas streams, specific conductance is larger during low flow because of ground-water contributions of dissolved carbonate minerals in underlying limestone (Jordan and Stamer, 1995). Specific conductance in stream water can increase as a result of point-source discharges from WWTFs and urban runoff (Pope and Putnam, 1997).

Specific conductance at the five monitoring sites ranged from about $150 \mu \mathrm{S} / \mathrm{cm}$ in the Blue River and Kill and Mill Creeks to 4,540 $\mu \mathrm{S} / \mathrm{cm}$ in Mill Creek (table 4). From March 2004 through 2006, specific conductance was nearly always largest at the Indian Creek site, followed by the Mill Creek site, the two most urban sites and the two sites with the largest WWTF contribution (fig. 5) which can lead to elevated specific conductance. All sites except Kill Creek show sharp increases in specific conductance during the 0 - to 15 -percent exceedance frequency (fig. 5), likely as a result of road-salt application. Specific conductance conditions in the Blue River and Kill Creek, both mainly undeveloped watersheds, were similar during the monitoring period. Cedar Creek, which also is predominantly undeveloped, had a median specific conductance about 25 percent larger than the Blue River and Kill Creek (fig. 5), possibly because of bedrock dissolution from large rock quarries in the upstream portions of the watershed. The Blue River and Kill Creek sites did not show major effects from road-salt application in 2005 (fig. 5).

\section{pH}

$\mathrm{pH}$ is a measure of the effective hydrogen ion concentration and is used as an index of the status of chemical and biological equilibrium reactions in water (Hem, 1992). The $\mathrm{pH}$ of natural water generally ranges from 6.5 to 8.5 standard units (Hem, 1992). Kansas aquatic-life-support criteria require that $\mathrm{pH}$ in streams measure not less than 6.5 and not more than 8.5 standard units (Kansas Department of Health and Environment, 2005).

pH ranged from 6.9 (Indian Creek in 2006) to 9.1 standard units (Cedar, Indian, and Mill Creeks) (table 4). From March 2004 through 2006, exceedances of the upper criterion of 8.5 standard units occurred at the Cedar, Indian, and Mill Creek sites less than 3 percent of the time (fig. 6). $\mathrm{pH}$ of streams in northeastern Kansas has been found to be slightly alkaline primarily because of the buffering capacity of the surficial soils and rocks (Jordan and Stamer, 1995). $\mathrm{pH}$ at the Indian Creek site remained less than $\mathrm{pH}$ at the other Johnson County sites most of the time, except during the 0 - to 10 -percent frequency-of-exceedance period when $\mathrm{pH}$ sharply increased and exceeded $\mathrm{pH}$ at the other sites (fig. 6). Urban runoff can be more acidic (Welch and Lindell, 1992), resulting in lesser values of $\mathrm{pH}$ at the Indian Creek site.

Table 6. Average annual precipitation in five watersheds of Johnson County, northeast Kansas, 2003-06 (data source http://www.stormwatch.com).

[--, not determined because collection sites were not yet operating]

\begin{tabular}{lrrrr}
\hline \multirow{2}{*}{$\begin{array}{c}\text { Watershed } \\
\text { (fig. 1) }\end{array}$} & \multicolumn{4}{c}{ Average annual precipitation, in inches } \\
\cline { 2 - 5 } & $\mathbf{2 0 0 3}$ & $\mathbf{2 0 0 4}$ & $\mathbf{2 0 0 5}$ & $\mathbf{2 0 0 6}$ \\
\hline Blue River & -- & 48.4 & 37.7 & 34.0 \\
Cedar Creek & 29.9 & 42.2 & 41.9 & 28.0 \\
Indian Creek & -- & 43.6 & 39.0 & 34.2 \\
Kill Creek & -- & 43.4 & 44.2 & 28.1 \\
Mill Creek & 29.7 & 43.8 & 43.6 & 30.7 \\
\hline
\end{tabular}




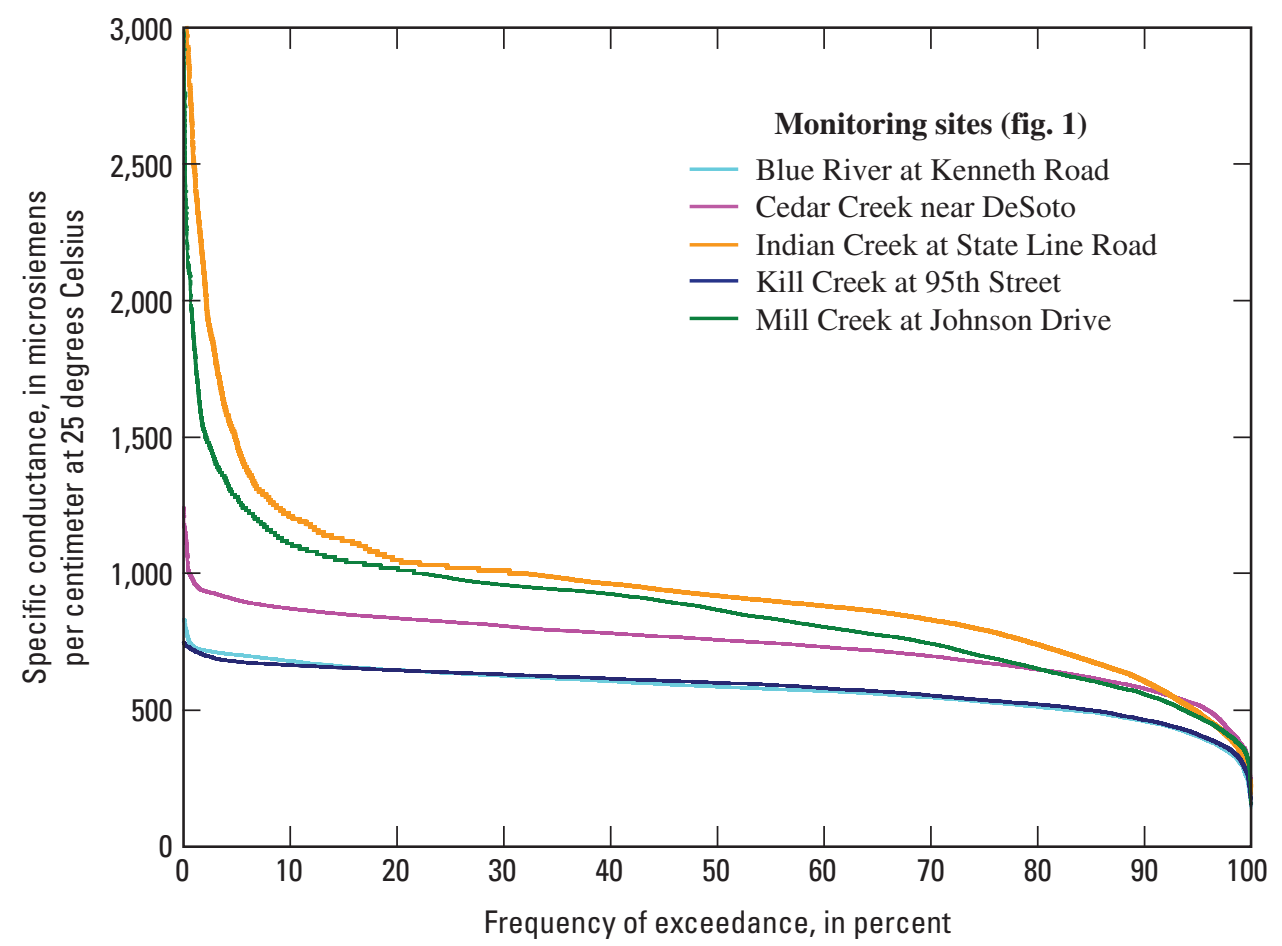

Figure 5. Duration curves for measured specific conductance at five monitoring sites in Johnson County, Kansas, March 2004 through December 2006.

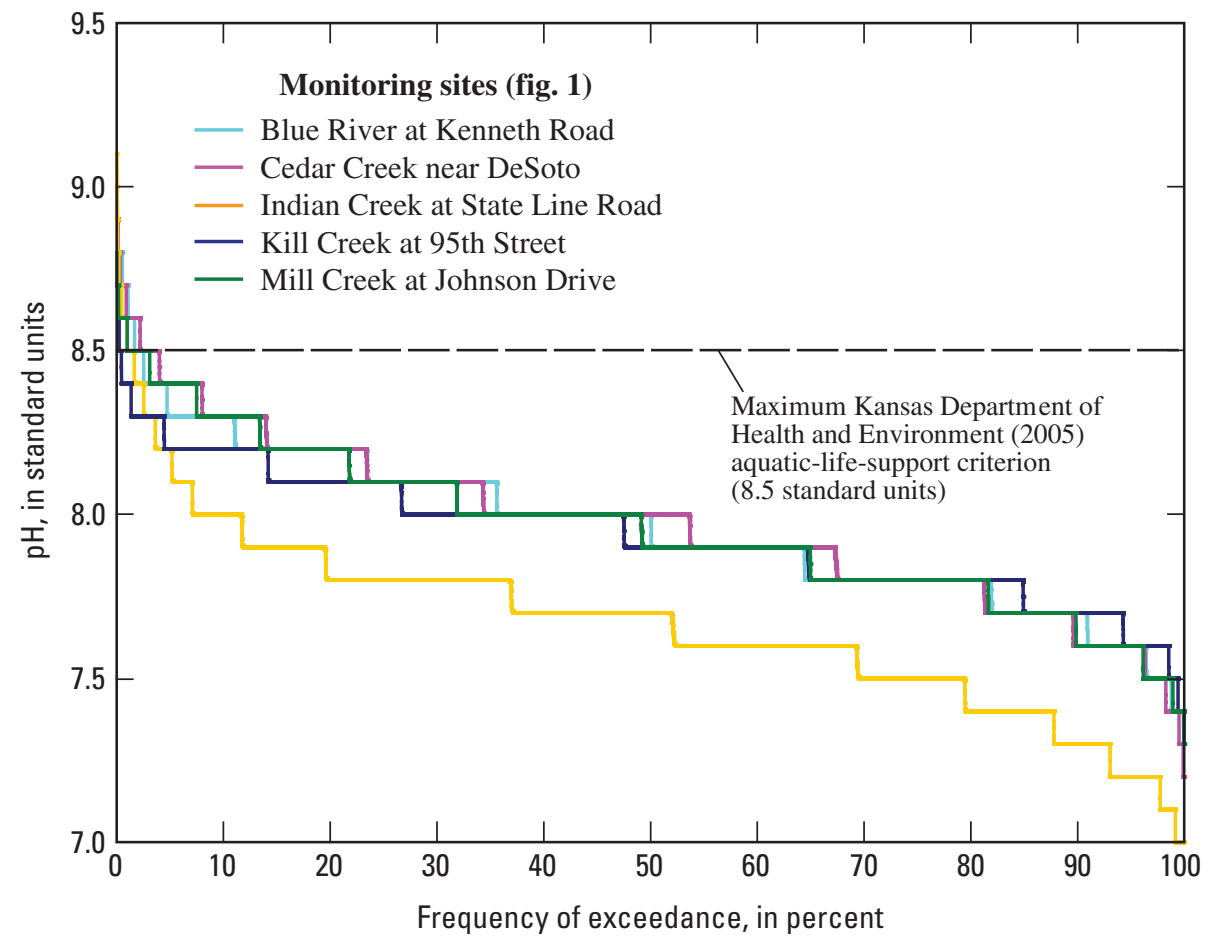

Figure 6. Duration curves for measured $\mathrm{pH}$ at five monitoring sites in Johnson County, Kansas, March 2004 through December 2006. 


\section{Water Temperature}

Water temperature has an important effect on the density of water, the solubility of constituents in water, specific conductance, $\mathrm{pH}$, the rate of chemical reactions, and biological activity in water (Wilde and others, 2006). Kansas water-quality criteria require that discharges to streams not raise the water temperature more than $3^{\circ} \mathrm{C}$ or raise the temperature above $32^{\circ} \mathrm{C}$ (Kansas Department of Health and Environment, 2005).

Water temperature ranged from about $0^{\circ} \mathrm{C}$ at all sites except Indian Creek to about $32^{\circ} \mathrm{C}$ at all sites (table 4). All the sites demonstrated similar water temperature conditions except Indian Creek. From March 2004 through 2006, the temperature of Indian Creek, the most urban site and the site most affected by WWTF discharge, exceeded that of the other sites about 60 percent of the time (fig. 7). The largest difference in water temperature between Indian Creek and the other less urban sites occurred at low temperatures (during winter months) when the temperature at the Indian Creek site was 2.5 to $3^{\circ} \mathrm{C}$ warmer than the other sites (table 4). Besides being affected by warmer wastewater discharges, increased water temperature in urban streams is caused by the decrease in streamside shade from loss of riparian habitat, heating of runoff from roads and parking lots, and generally warmer temperatures formed by cities (Galli, 1991; LeBlanc and others, 1997; Paul and Meyer, 2001).

\section{Turbidity}

Turbidity is caused by suspended and dissolved matter such as clay, silt, finely divided organic matter, plankton and other microscopic organisms, organic acids, and dyes (ASTM International, 2003; Anderson, 2005). Turbidity is affected by the amount of precipitation and runoff, intensity and duration of storms, slope of the river channel, geomorphic structure of the channel, origin of the water including point and nonpoint sources, and time of travel from the point of origin to the point of measurement. Biological activity, such as algal blooms, can increase turbidity. Particulates in water provide attachment sites for nutrients, pesticides, indicator bacteria, and other potential contaminants. Also, increased turbidity reduces light penetration and photosynthesis, smothers benthic habitats, and interferes with feeding activities. Very large values of turbidity for short periods of time may be less harmful than smaller values that persist (Wetzel, 2001). USEPA level III ecoregion 40 recommended criteria for turbidity is 15.5 nephelometric turbidity units (U.S. Environmental Protection Agency, 2003b). The instrument technology used in this study to measure turbidity in formazin nephelometric units (FNUs) is appropriate for comparison to the criteria, which are expressed in nephelometric turbidity units (NTUs).

Turbidity values ranged from less than 2 FNUs at all sites annually to about 2,000 FNUs at the Cedar and Mill Creek sites (table 4). During infrequent storms at the Mill and
Kill Creek monitoring sites (less than 1 percent of the time), turbidity exceeded the maximum value the sensor was capable of measuring; therefore, the absolute maximum turbidity at those sites is unknown. From March 2004 through 2006 turbidity values at the Blue River, Kill and Mill Creek sites were similar except within the 90- to 100-percent frequency range when the Kill Creek values dropped to nearly 0 (fig. 8). The Indian Creek site had the smallest turbidity most of the time (fig. 8), probably because of the high clarity of WWTF discharge, which dominates streamflow at that site most of the time (Lee and others, 2005). The largest turbidity measurements at all sites occurred during storm runoff. The USEPArecommended ecoregion criterion was exceeded 20 to 30 percent of the time (fig. 8).

\section{Dissolved Oxygen}

The dissolved oxygen (DO) concentration in surface water is related primarily to photosynthetic activity of aquatic plants, atmospheric reaeration, and water temperature (Lewis, 2006). Diffusion of oxygen across the air-water interface can be a major factor affecting DO concentrations for small, shallow streams with a high surface area to volume ratio (Huggins and Anderson, 2005). DO is an important factor in chemical reactions and the survival of aquatic organisms. Kansas aquatic-life- support criterion requires that DO concentrations are not less than $5.0 \mathrm{mg} / \mathrm{L}$ (Kansas Department of Health and Environment, 2005).

Continuous dissolved oxygen concentration ranged from about $1 \mathrm{mg} / \mathrm{L}$ at the Cedar Creek site in 2003 and the Indian and Mill Creek sites in 2006, to $24 \mathrm{mg} / \mathrm{L}$ at the Mill Creek site in 2004 (table 4). From March 2004 through December 2006, DO concentrations were less than the KDHE criterion of $5.0 \mathrm{mg} / \mathrm{L}$ less than about 10 percent of the time at all sites except Indian Creek, which was less than the criterion about 15 percent of the time (fig. 9A). Low DO at all sites generally coincided with higher water temperatures resulting in decreased oxygen solubility in water. More frequent low DO at Indian Creek likely was caused by WWTF discharges that contribute nutrients increasing growth of microorganisms that consume nutrients and reduce DO.

Low DO at all sites occurred during all three seasonal periods but most frequently at the Indian Creek site and during the August-October period (fig. 9B), corresponding with the lowest streamflow, warmest water temperatures, and likely high algal activity. Most DO values less than $5.0 \mathrm{mg} / \mathrm{L}$ at Blue, Cedar, and Kill also coincided with low-flow conditions during mid- to late summer. Streamflow reduced by irrigation withdrawals just upstream from the monitor may contribute to low DO values at the Blue River site during dry periods. Generally, larger DO concentrations were sustained at all sites during winter because the solubility of oxygen is greater in colder water (Hem, 1992). However, the largest DO concentrations (in excess of $20 \mathrm{mg} / \mathrm{L}$ at all sites except Blue River sometime during the monitoring period) occurred during 


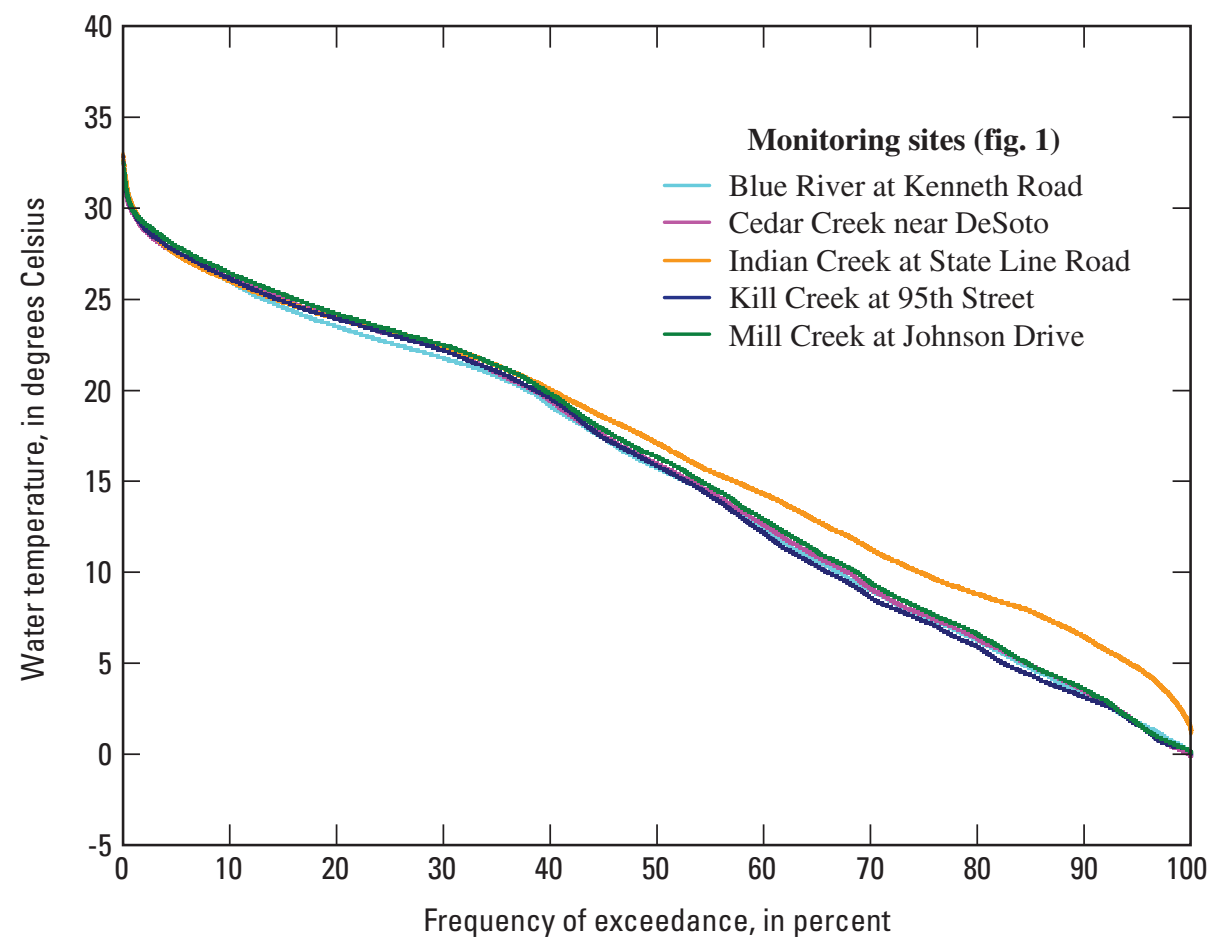

Figure 7. Duration curves for measured water temperature at five monitoring sites in Johnson County, Kansas, March 2004 through December 2006.

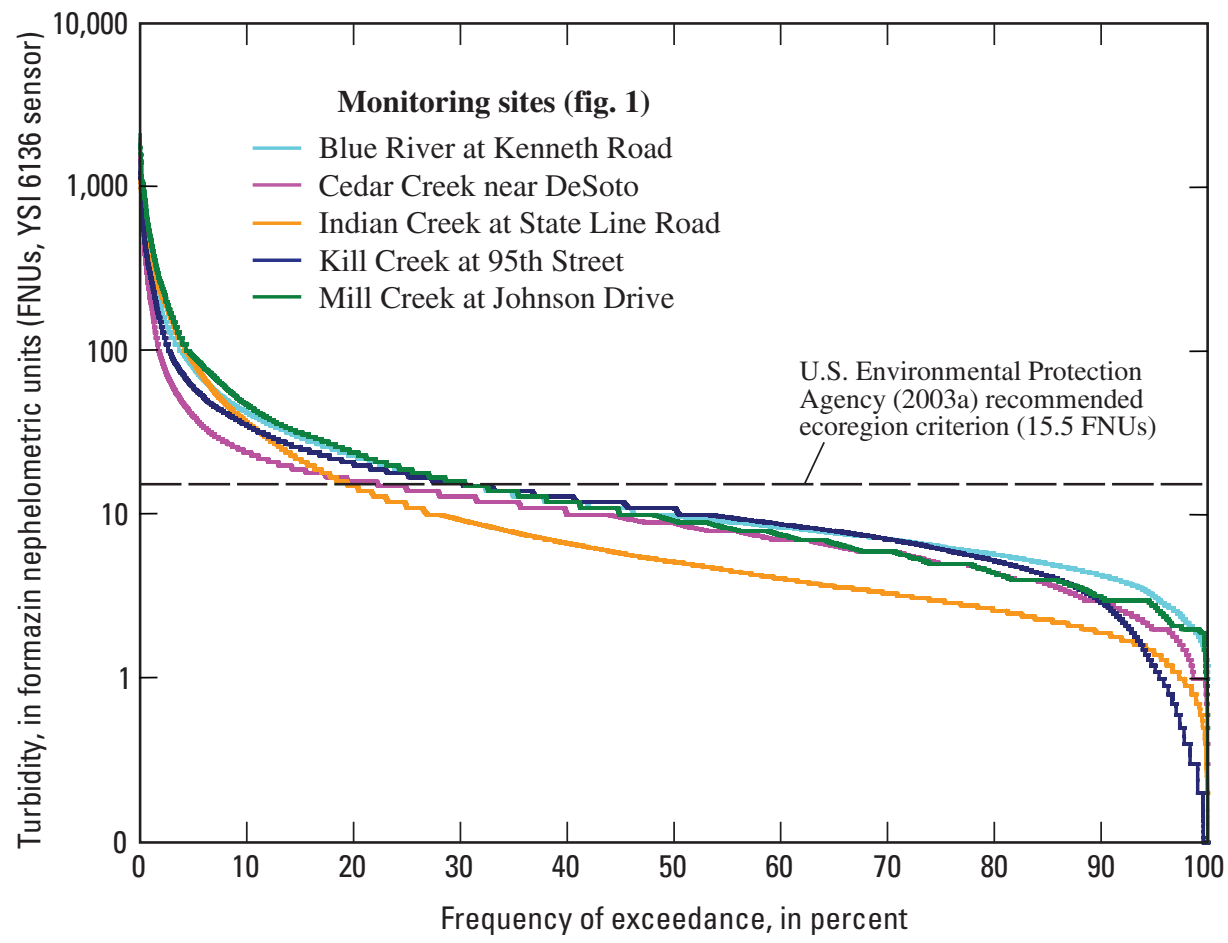

Figure 8. Duration curves for measured turbidity at five monitoring sites in Johnson County, Kansas, March 2004 through December 2006. 
(A) Measured dissolved oxygen at five monitoring sites in Johnson County, Kansas, March 2004-December 2006

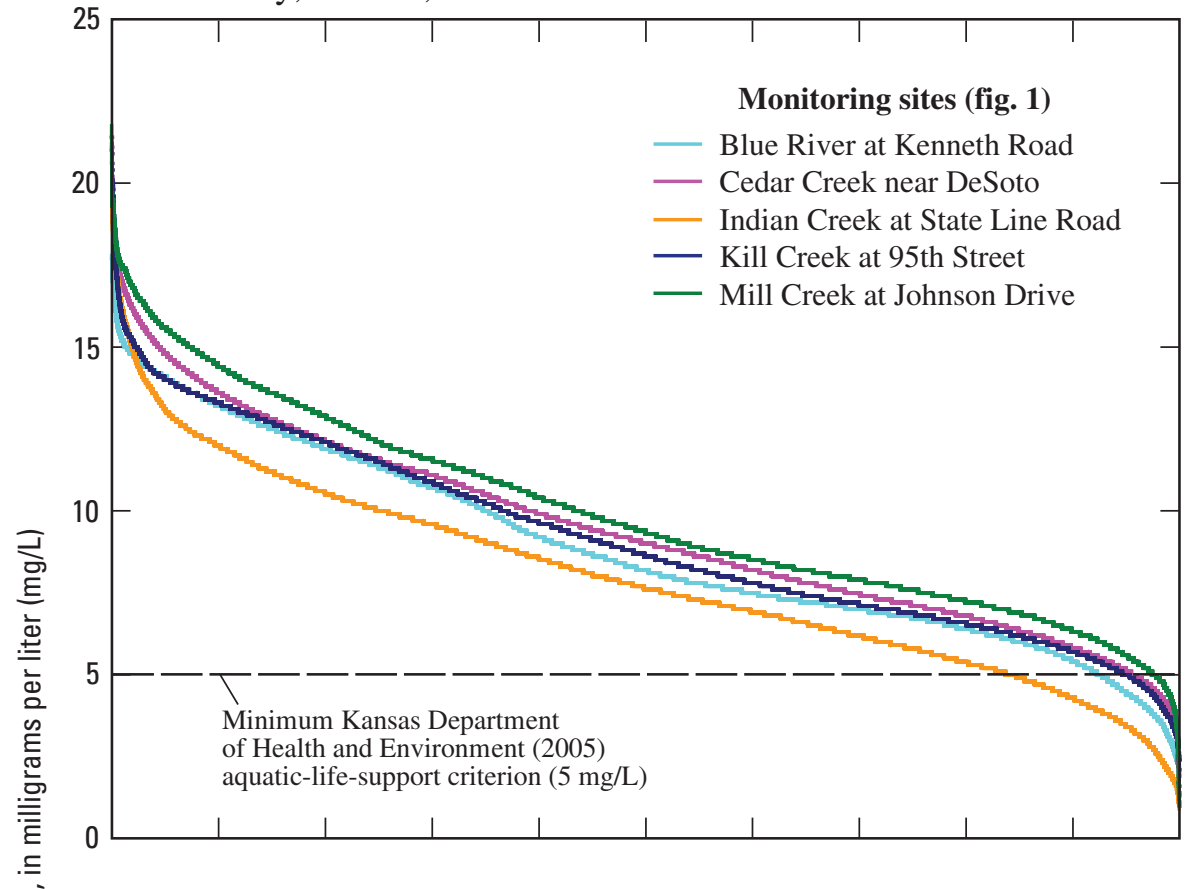

(B) Seasonal dissolved oxygen at Indian Creek at State Line Road (station 06893390, fig. 1), January 2005-December 2006

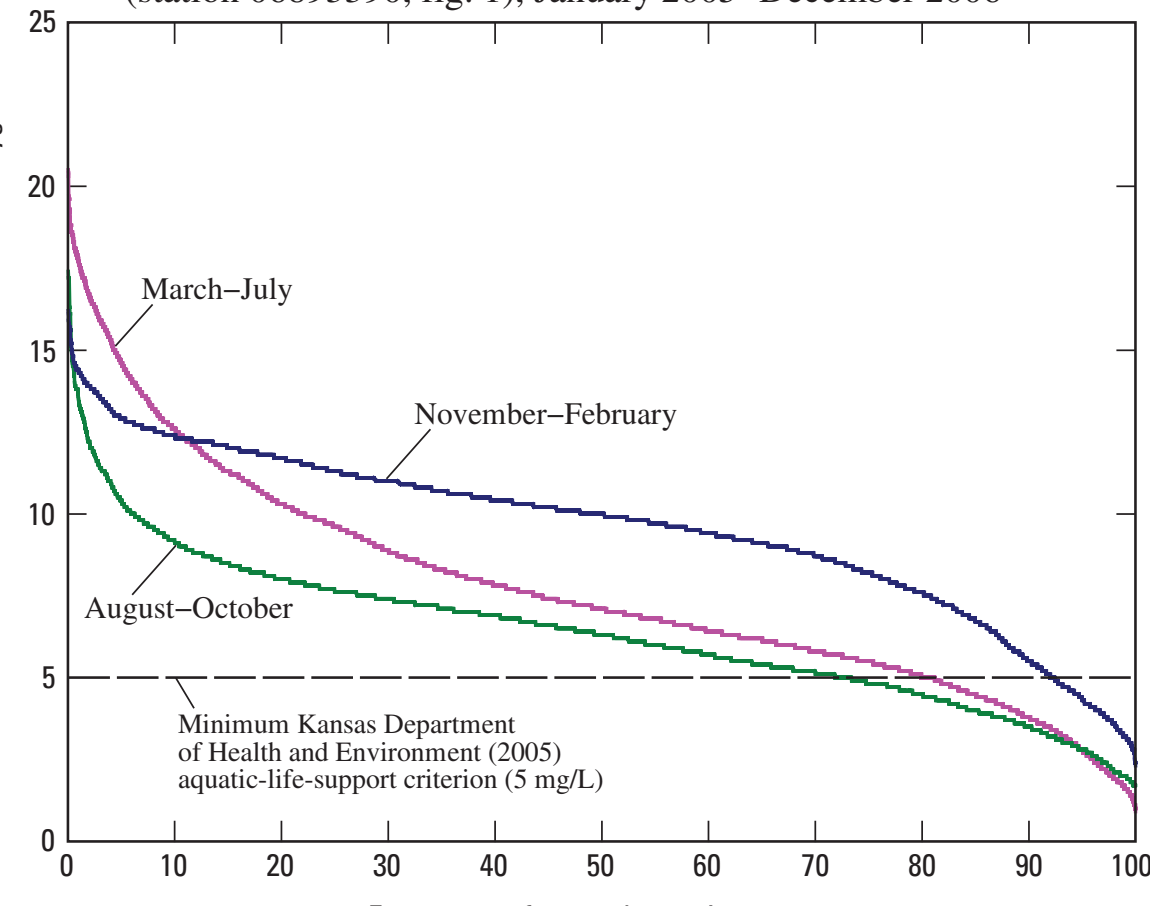

Figure 9. Duration curves for $(A)$ measured dissolved oxygen at five monitoring sites in Johnson County, Kansas from March 2004 through December 2006 and (B) seasonal dissolved oxygen at the Indian Creek monitoring site for January 2005 through December 2006. 
spring and summer when algal activity is high. For example, at the Indian Creek site during 2005-06, DO generally was largest during the winter months (November-February), but the largest measurements occurred during about 10 percent of the time during the March-July period (fig. 9B).

\section{Variability in Streamflow and Water-Quality Measurements}

A typical example of the water-quality variability that occurred in Johnson County streams is provided in figures $10 \mathrm{~A}$ and $10 B$ using August 2005 data from the Indian Creek monitoring site. Distinct daily fluctuations occurred in $\mathrm{pH}$, water temperature, and DO until changes in streamflow disturbed the patterns (fig. 10A). Daily variability in $\mathrm{pH}$ and $\mathrm{DO}$ is an indication of photosynthetic activity and is affected by availability of sunlight and nutrients (Wetzel, 2001). During the day, photosynthesis by aquatic plants increases the amount of oxygen dissolved in the water and decreases dissolved carbon dioxide, thus increasing $\mathrm{pH}$ during the daytime. Oxygen is consumed and carbon dioxide is released during respiration and decomposition, which occur throughout the day and night, resulting in lower $\mathrm{pH}$ and $\mathrm{DO}$ during the night. $\mathrm{pH}$ and $\mathrm{DO}$ fluctuations generally were more extreme at sites immediately downstream from WWTFs, like the Indian Creek site, because of increased algal activity from increased nutrient contributions from WWTFs. Increases in $\mathrm{pH}$ and water temperature result in an increase in the toxicity of ammonia for fish (Kansas Department of Health and Environment, 2005).

Rapid changes in specific conductance and turbidity associated with changes in streamflow occurred in Johnson County streams, as seen in data from the Indian Creek monitoring site (fig. 10B). Typically, specific conductance decreases and turbidity increases in response to storm runoff. Three different streamflow response sequences occurred in August 2005 as a result of precipitation and runoff. During runoff on August 19, 2005 , turbidity increased to about 1,100 FNUs when streamflow peaked at about $1,400 \mathrm{ft}^{3} / \mathrm{s}$. The following day, a much larger streamflow peak of more than $6,000 \mathrm{ft}^{3} / \mathrm{s}$ was accompanied by a much smaller turbidity peak of about 600 FNUs. A similar response occurred about a week later. This indicates that the magnitude of the streamflow peak does not necessarily determine the magnitude of the turbidity peak. In both cases, turbidity increased from less than 40 FNUs to more than 1,000 FNUs in less than 5 hours. Turbidity fluctuations are affected by the source of sediment (channel bank or bed, or overland erosion), distance from the source, rainfall intensity, and length of time since the last runoff occurrence. The two pairs of streamflow and turbidity peaks that occurred at the Indian Creek site August 19-20 (fig. 10B) likely represented runoff from the two primary watersheds upstream from the monitoring site (Indian and Tomahawk Creeks) arriving at different times.

\section{Relation Between Streamflow and Turbidity}

Correlations between continuously measured streamflow and turbidity values at each monitoring site (at the Cedar Creek site, for example, fig. 11) in 2005-06 are poor, with coefficients of determination $\left(\mathrm{R}^{2}\right)$ ranging from 0.39 to 0.55 (table 7). Although the largest turbidity values occurred during stormwater runoff, peak turbidity values most often do not coincide with peak streamflow values. Turbidity peaks can either precede or follow associated streamflow peaks. Effects of these differences in turbidity during the rising and falling limbs of streamflow peaks (hysteresis) can be seen in the curved pattern (red line) within the data plotted in figure 11. Because the relation between streamflow and turbidity is complex, alternative interpretive tools are useful.

Williams (1989) and Nistor and Church (2005) describe patterns of streamflow and suspended-sediment concentration and explain sediment sources and transport characteristics on the basis of observed patterns. According to Nistor and Church (2005), the most common pattern is the clockwise hysteresis loop (Type 2, fig. 12B), which indicates depletion of available sediment before the streamflow peak occurs. Counterclockwise hysteresis (Type 4, fig. 12C) indicates delayed sediment travel time resulting from the downstream distance of the measuring station from the sediment source (Williams, 1989). Single-line curves (Type 1, fig. 12A) occur when an unlimited supply of sediment is available throughout runoff resulting in simultaneous peaks in both suspended-sediment concentration and streamflow (Williams, 1989). Variations such as figureeight patterns and multiple loops (Type 2 or 4 , fig. 12D) occur because of bank collapses and tributary inflows, and these patterns also are affected by changes in precipitation and runoff rates, sediment availability, and rates and distances of travel (Williams, 1989). According to Asselman (1999), suspended sediment originating from the stream channel typically causes larger turbidity values during the rising limb of a streamflow peak (clockwise hysteresis), and sediment originating from more distant basin sources often causes larger turbidity values during the falling limb (counterclockwise hysteresis).

Streamflow and turbidity data from the monitoring sites in the study area were examined for hysteresis patterns during various runoff periods (fig. 13). Generally, large runoff resulted in clockwise hysteresis patterns (fig. 13A, for example), indicating sediment depletion during runoff (Nistor and Church, 2005) and substantial sediment contributions likely from the stream channel (Asselman, 1999). Small runoff, which occurred more frequently but resulted in smaller turbidity values compared to larger runoff, often resulted in counterclockwise hysteresis patterns (fig. 13B, for example) indicating sediment likely originated from more distant basin sources (Asselman, 1999; Nistor and Church, 2005). The Indian Creek site experienced more runoff periods showing single-line curve characteristics (fig. 13C) than any other site, indicating unlimited sediment supplies during several runoff periods that occurred that year. Characterizing turbidity changes during varying streamflow conditions leads to a 
(A) Variability in streamflow, $\mathrm{pH}$, water temperature, and dissolved oxygen
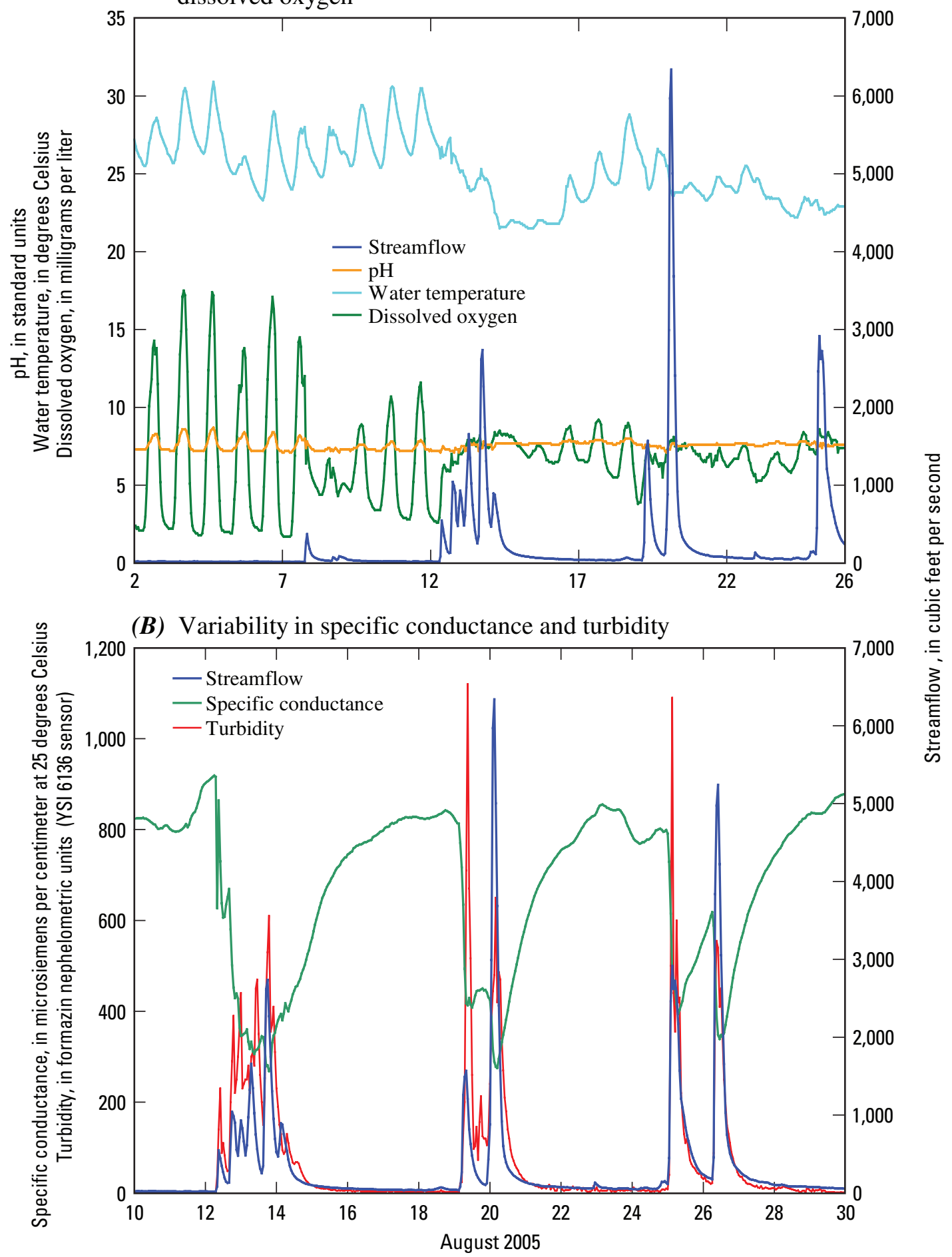

Figure 10. Variability in (A) streamflow, $\mathrm{pH}$, water temperature, and dissolved oxygen, and (B) specific conductance and turbidity at the Indian Creek monitoring site in Johnson County, Kansas, August 2005. 
Table 7. Relation between hourly streamflow (y) and turbidity $(\mathrm{x})$ measurements at five water-quality monitoring sites in Johnson County, northeast Kansas, 2005-06.

\begin{tabular}{lccc}
\hline \multicolumn{1}{c}{$\begin{array}{c}\text { Continuous monitoring site } \\
\text { (fig. 1) }\end{array}$} & $\begin{array}{c}\text { Station number } \\
\text { (fig. 1) }\end{array}$ & Equation & Coefficient of determination (R') \\
\hline Blue River at Kenneth Road & 06893100 & $\mathrm{y}=2.42 \mathrm{x}-11.2$ & 0.39 \\
Cedar Creek near DeSoto & 06892495 & $\mathrm{y}=1.80 \mathrm{x}+6.93$ & .48 \\
Indian Creek at State Line Road & 06893390 & $\mathrm{y}=4.13 \mathrm{x}+2.64$ & .47 \\
Kill Creek at 95th Street & 06892360 & $\mathrm{y}=2.41 \mathrm{x}-15.0$ & .50 \\
Mill Creek at Johnson Drive & 06892513 & $\mathrm{y}=1.95 \mathrm{x}-3.47$ & .55 \\
\hline
\end{tabular}

better understanding of concentration and loading properties for sediment and sediment-associated constituents like bacteria and some nutrients.

\section{Regression-Estimated Constituent Concentrations, Densities, Loads, and Yields}

Regression models for estimating selected waterquality constituents at the five continuous monitoring sites are presented and discussed in this section, followed by regression-estimated concentrations, densities, loads, and yields. Three constituents (suspended sediment, chloride, and
E. coli bacteria) are discussed in more detail than the others. These three particular constituents were selected for additional discussion because they represent three major categories of concern in Johnson County streams (sediment, major ions, and indicator bacteria) that have been identified as sources of water-quality impairment by KDHE (Kansas Department of Health and Environment, 2006a).

\section{Regression Models}

Regression models and summary statistics for estimating water-quality constituents in the five monitored streams in Johnson County are presented in table 8. Separate models were developed for each monitoring site. Models were included in table 8 if at least one significant ( $p$-value less

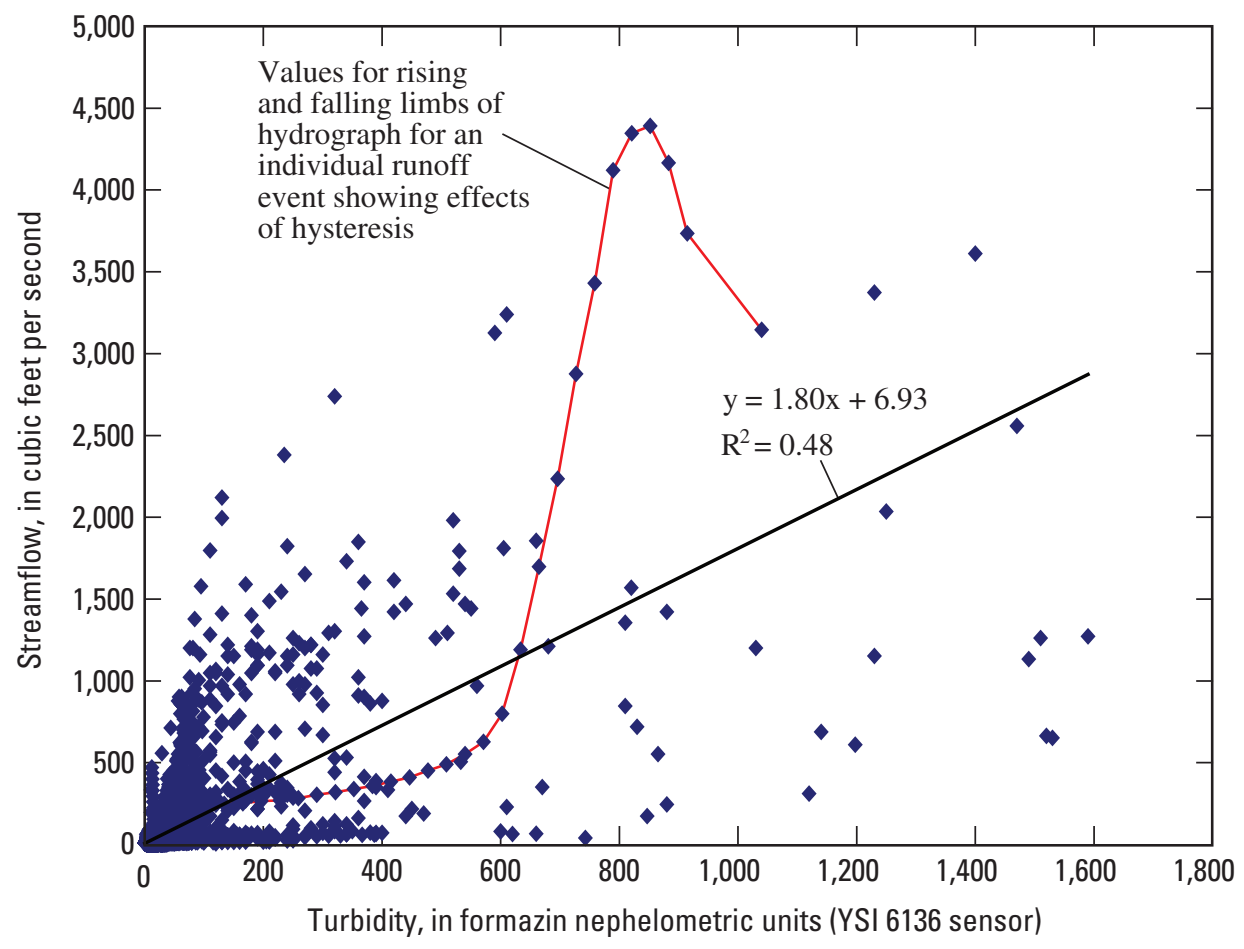

Figure 11. Comparison of continuously measured (hourly) streamflow and turbidity at the Cedar Creek monitoring site, Johnson County, Kansas, January 2005 through December 2006. 
(A)

Type 1 - Unlimited sediment supply

(B)

Type 2 - Limited sediment supply

(C)

Type 4 - Distant source of sediment, new source, or bank collapse

(D)

Type 2 or 4 Variation - New sediment source or bank collapse

\author{
Suspended-sediment \\ concentration $(\mathrm{C})$ \\ and streamflow $(\mathrm{Q})$ \\ over time
}

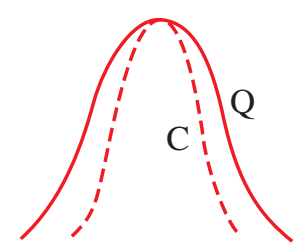

Suspended-sediment

concentration over

the storm hydrograph
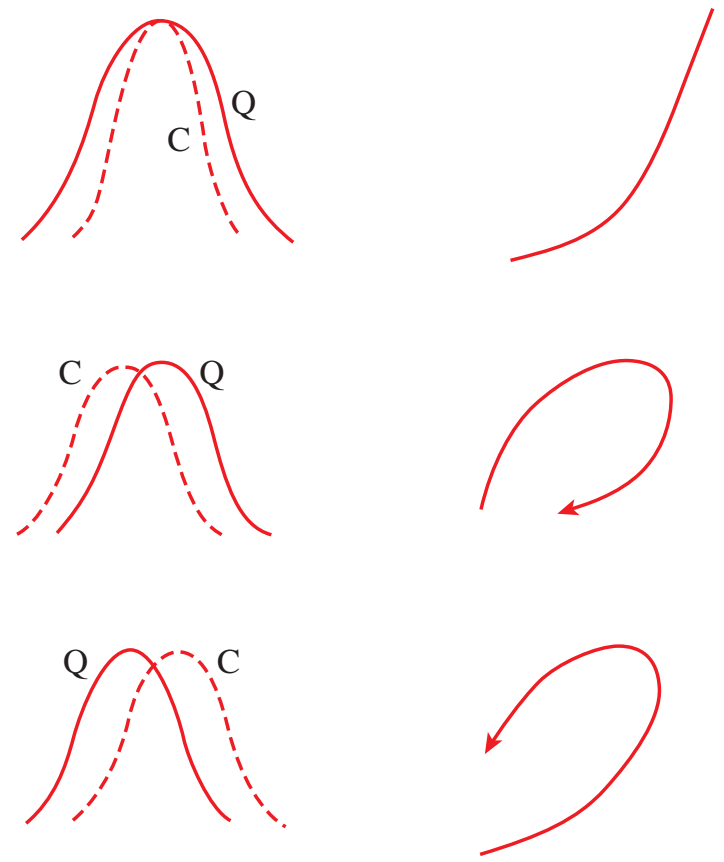

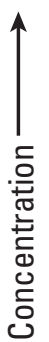

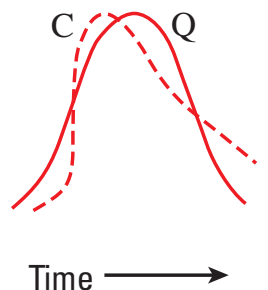

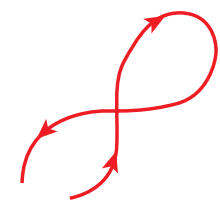

Streamflow $\longrightarrow$

Figure 12. Common streamflow and suspended-sediment hysteresis patterns, types, and sediment source explanations [adapted from Williams (1989) and Nistor and Church (2005)].

than 0.05 ) explanatory variable was found. Summaries of discrete-sample data in table 8 may not identically match summaries in other tables within this report because table 8 presents specific information for each site and constituent, and models require each discrete-sample data point (response variable) to be paired with available explanatory variable data.

Uncertainties associated with each model varied because of the number of samples collected, water-quality conditions at the time of sample collection including rapidly changing conditions, cross-section variability during sample collection, sampling and analytical error, and other factors affecting independent variables. Generally, for most constituents, models for the less urban sites (Blue River and Kill Creek) contained less variability than models for the more urban sites (Indian and Mill Creeks). This is because water quality in urban areas is more complex as a result of multiple sources and often altered pathways (Driver and Troutman, 1989).

Specific conductance and turbidity were the most common explanatory variables used in the models. Specific conductance is the primary explanatory variable for models estimating major ions because of the strong relation between specific conductance and dissolved ions. Turbidity was the primary explanatory variable for constituents associated with particulates, such as suspended-sediment concentration, unfiltered nutrient species, and fecal-indicator bacteria because these constituents attach to sediment particles. Most of the models include one of these two explanatory variables. However, some of the models also included streamflow as an explanatory variable, and several of the nutrient models included seasonal sine and cosine variables, indicative of the seasonal nature of some nutrient sources. 
(A) Cedar Creek near DeSoto (station 06892495, fig. 1)
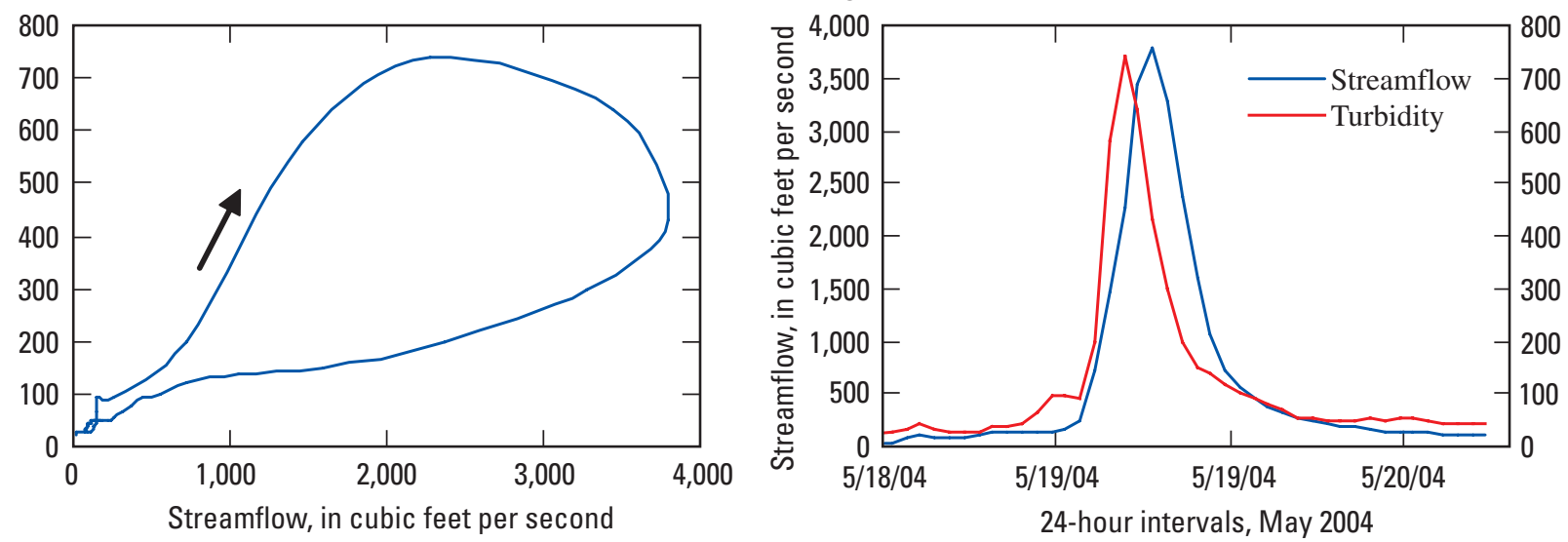

(B) Blue River at Kenneth Road (station 06893100, fig. 1)
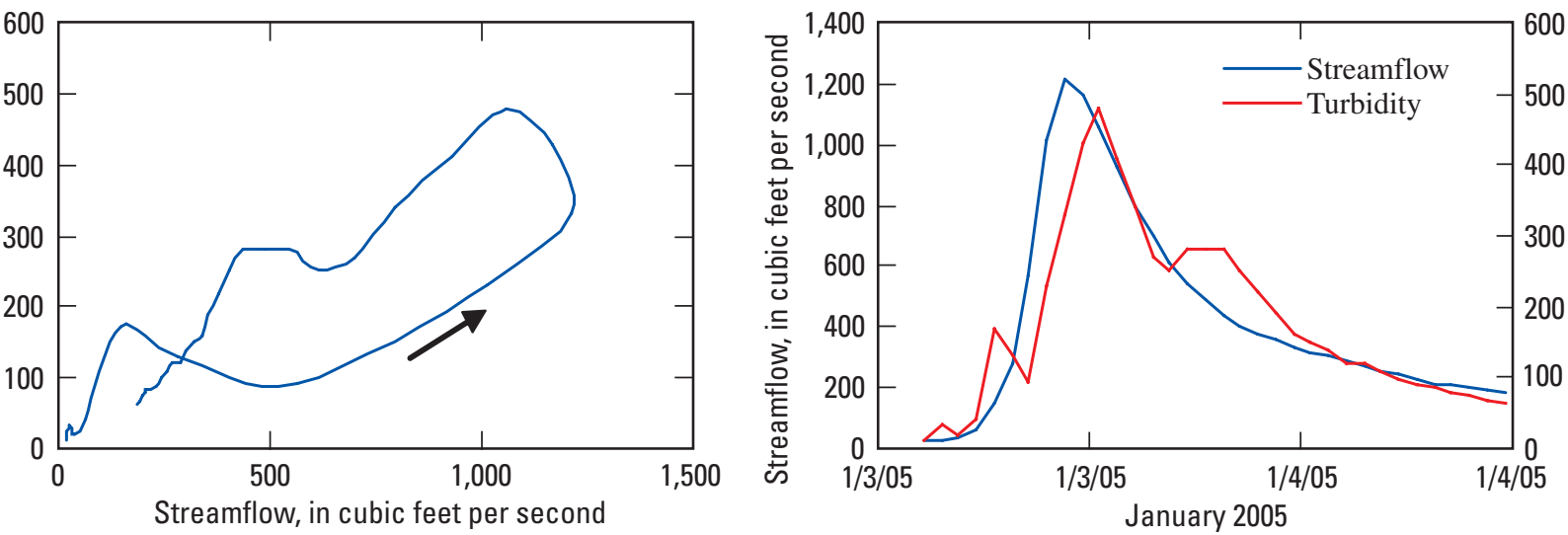

(C) Indian Creek at State Line Road (station 06893390, fig. 1)
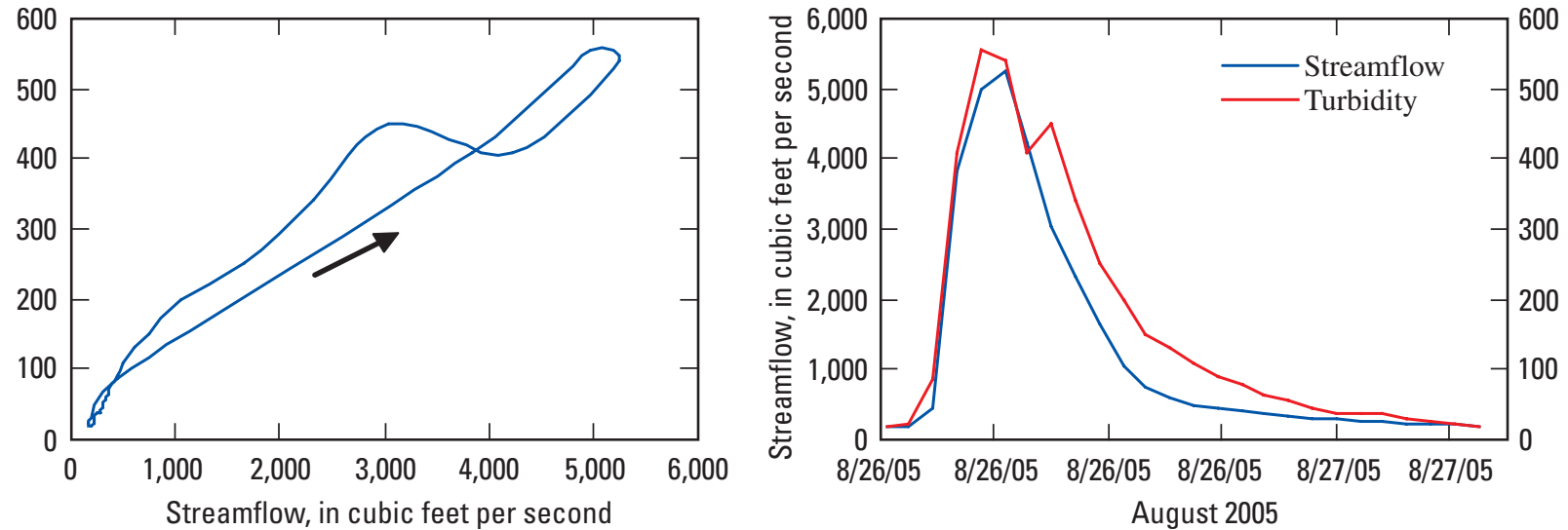

Figure 13. Examples of hysteresis patterns in streamflow and turbidity data from selected monitoring sites in Johnson County, northeast Kansas, 2005 (arrows indicate direction of hysteresis). 


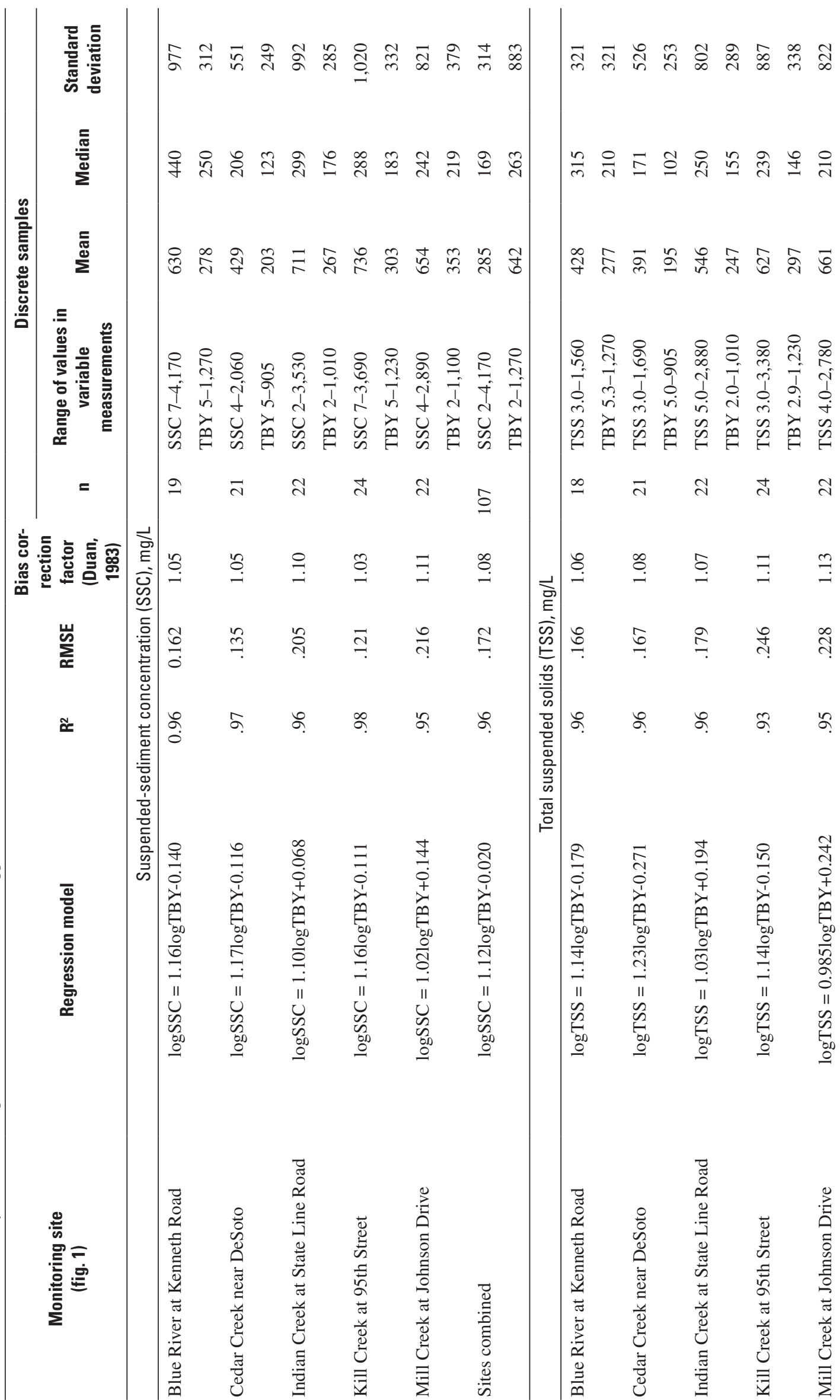




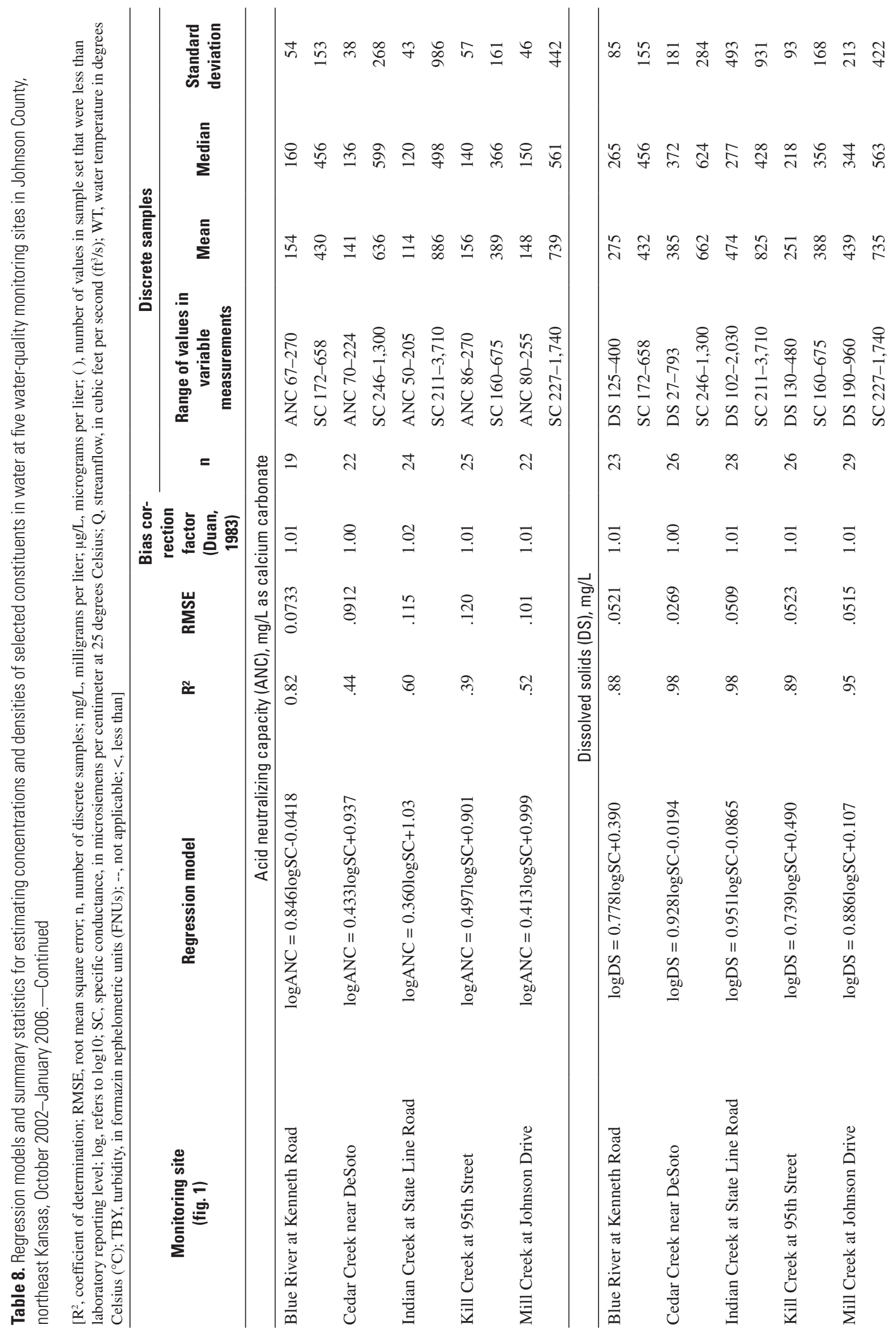




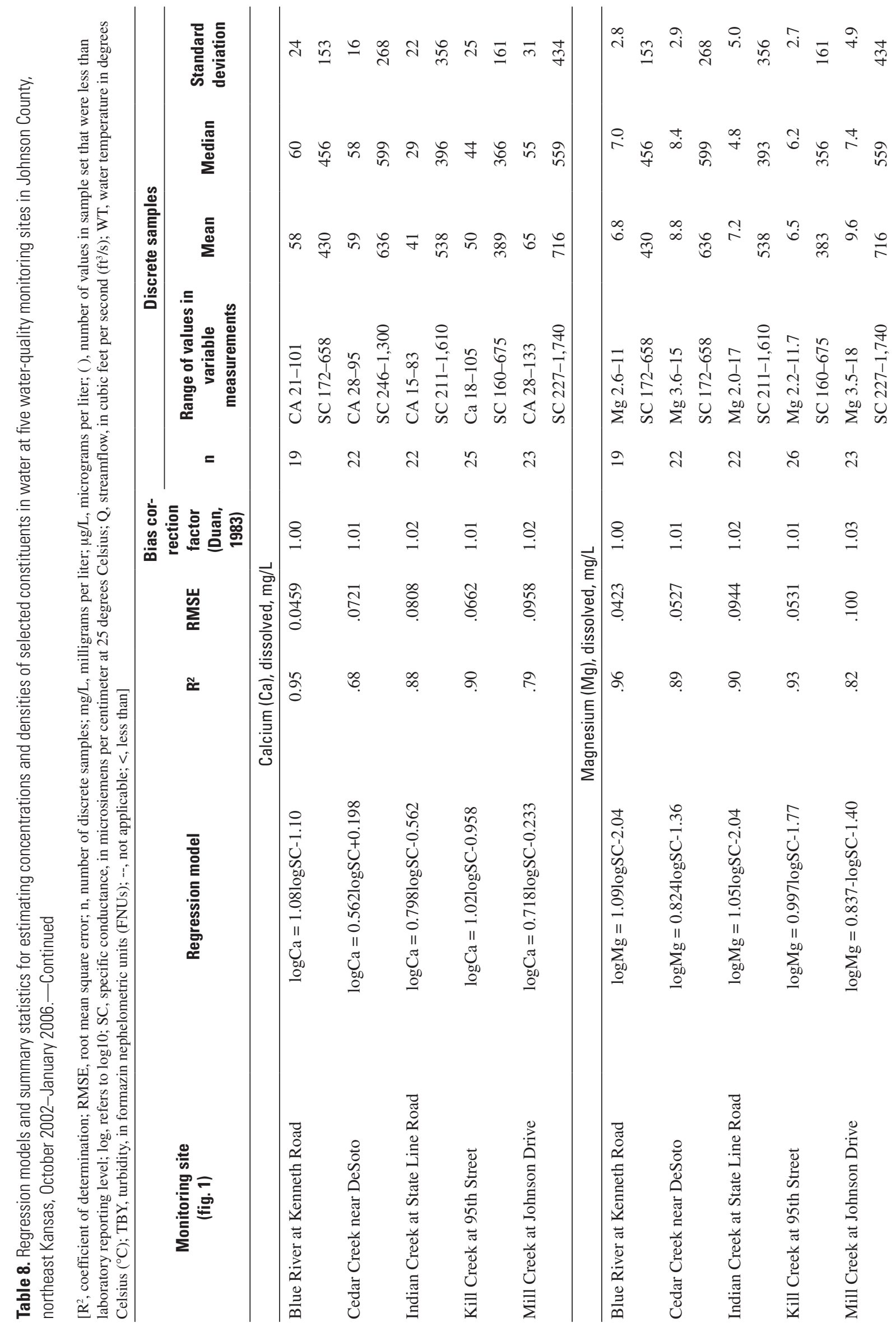




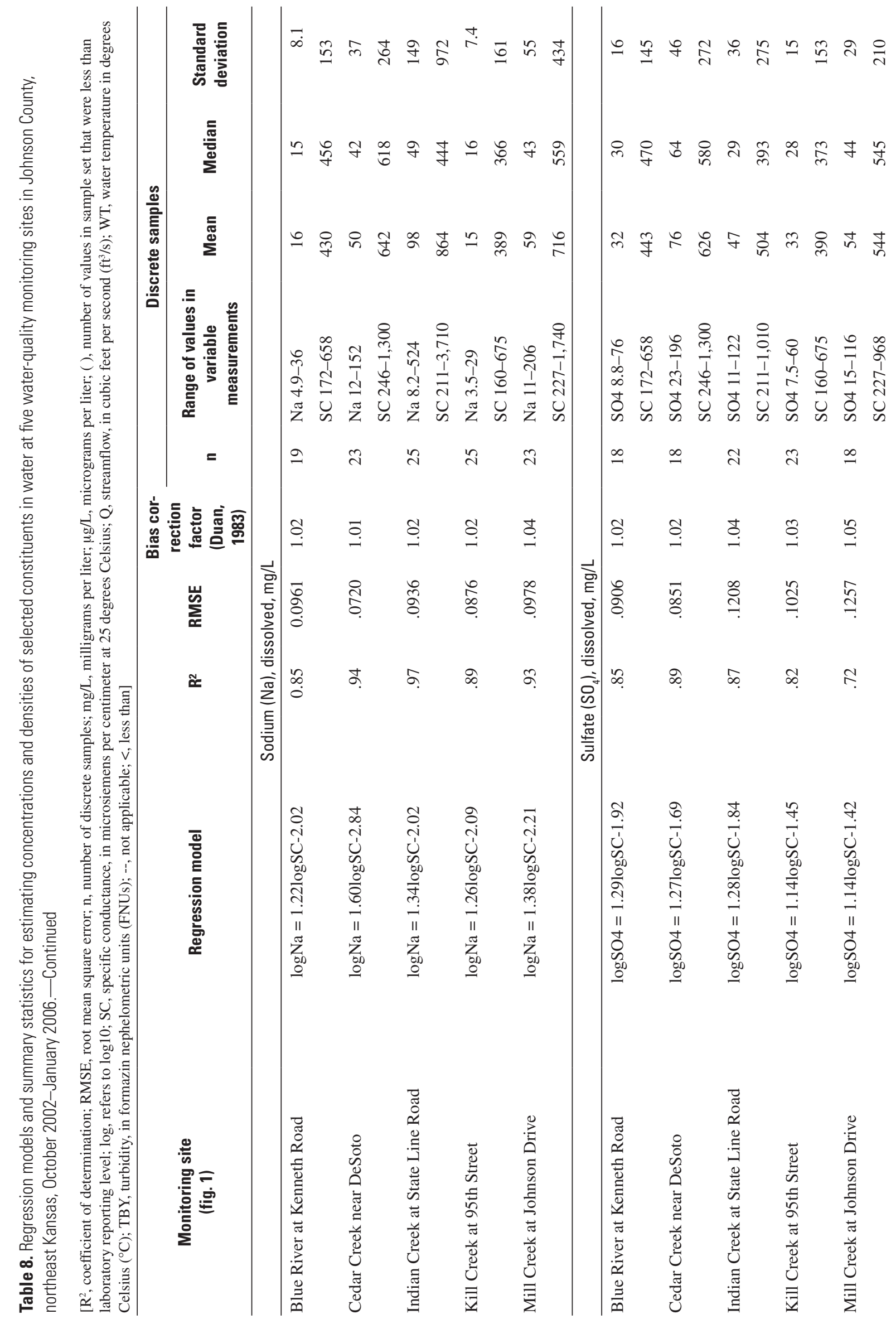




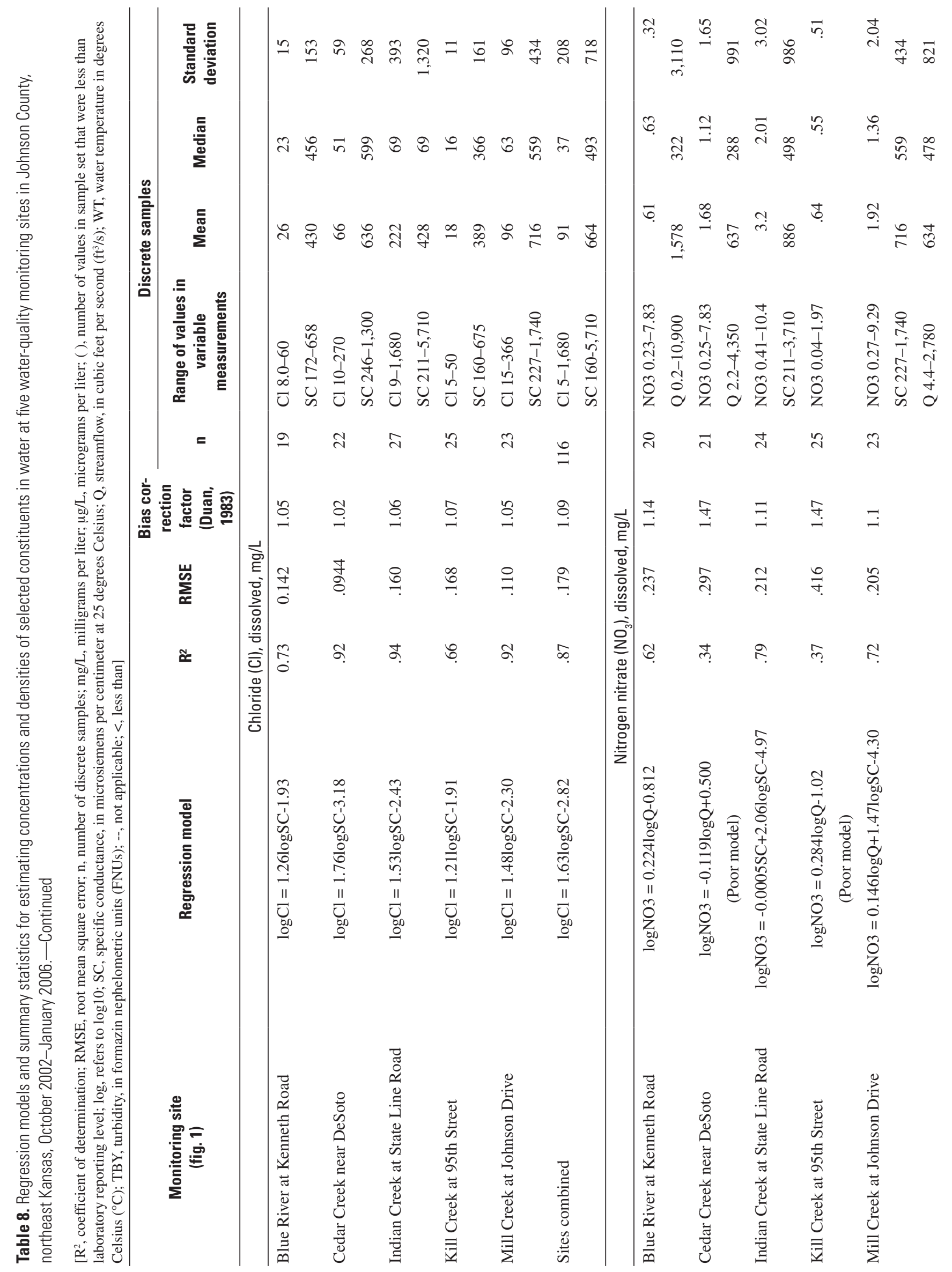




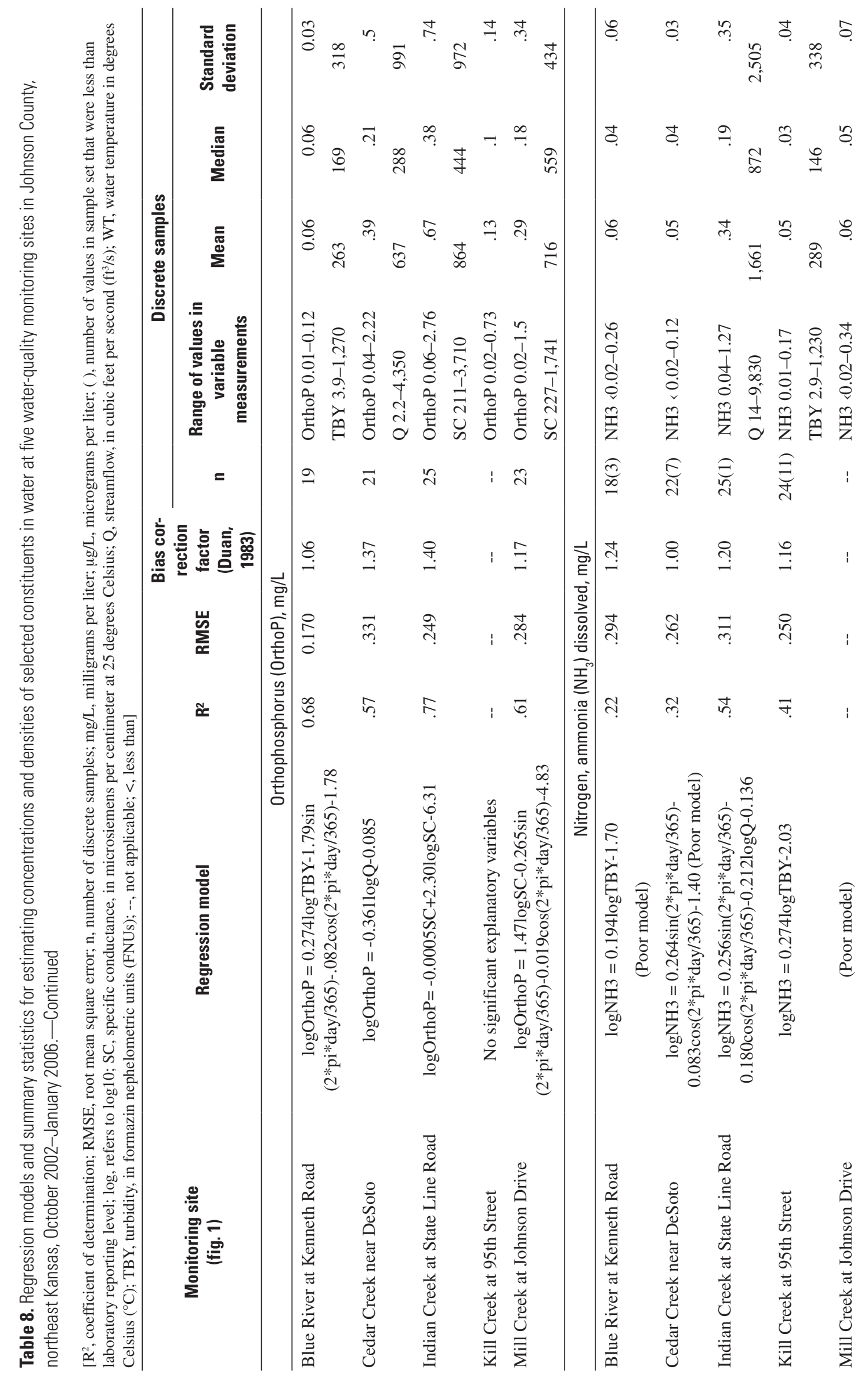




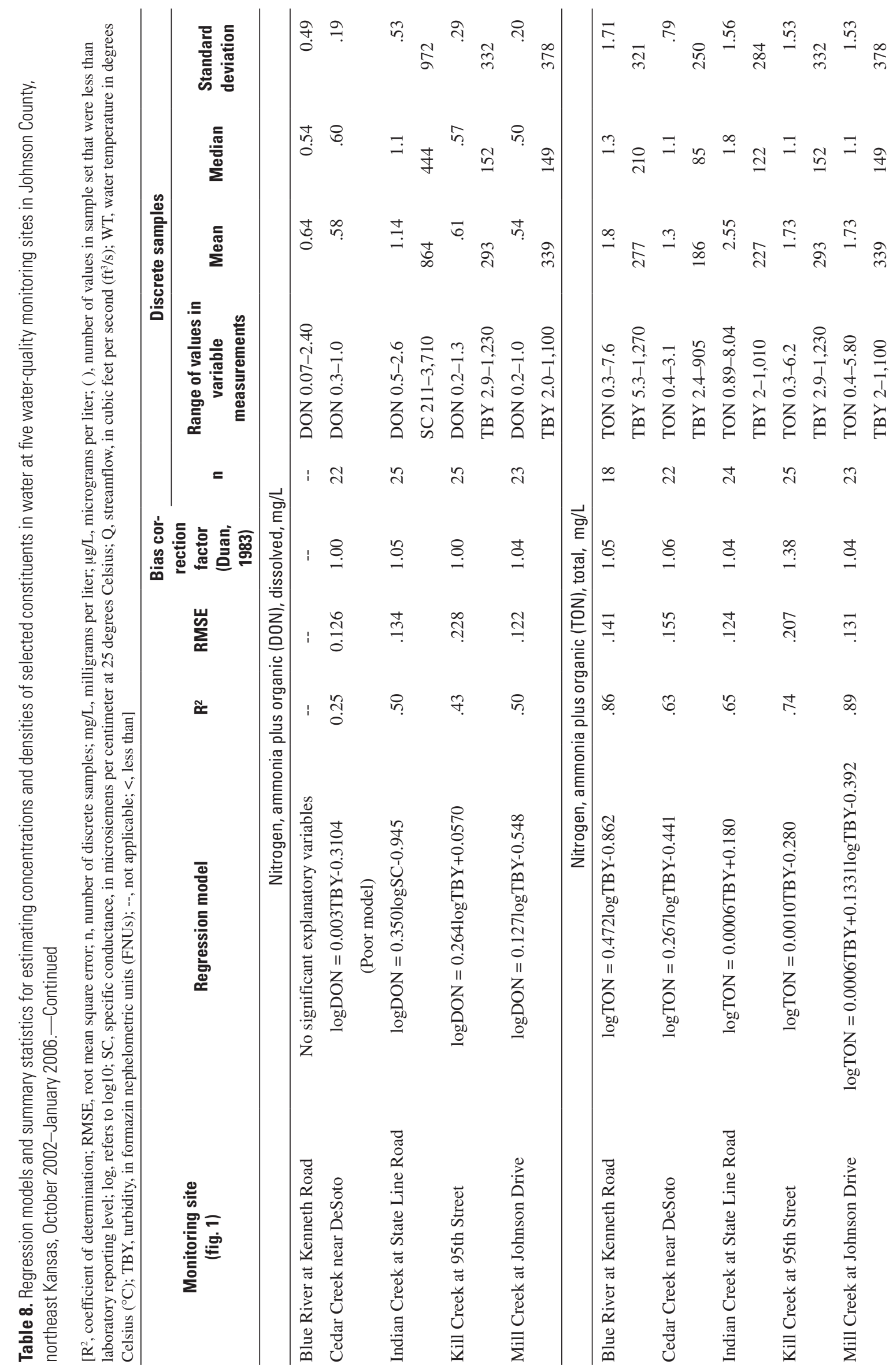




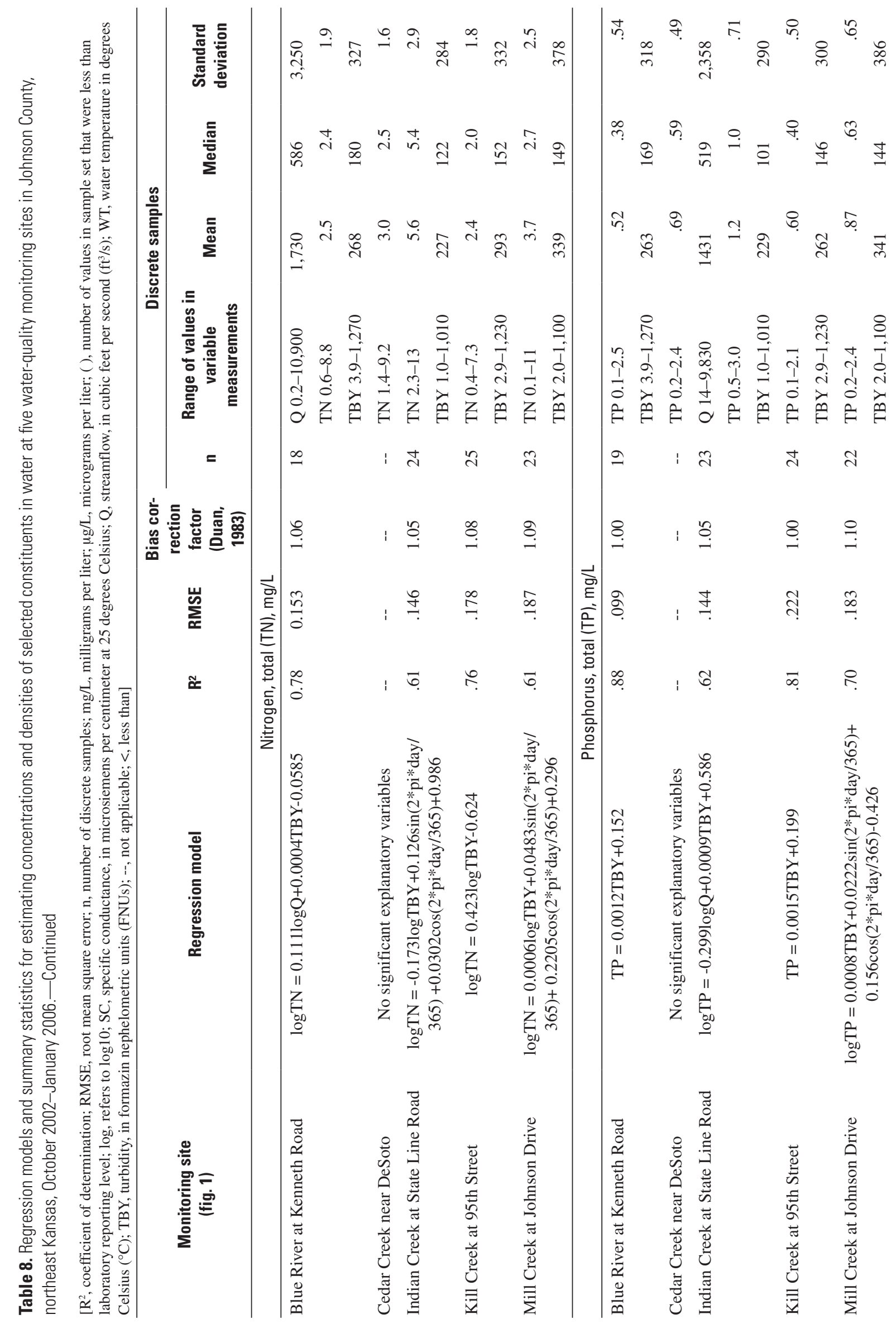




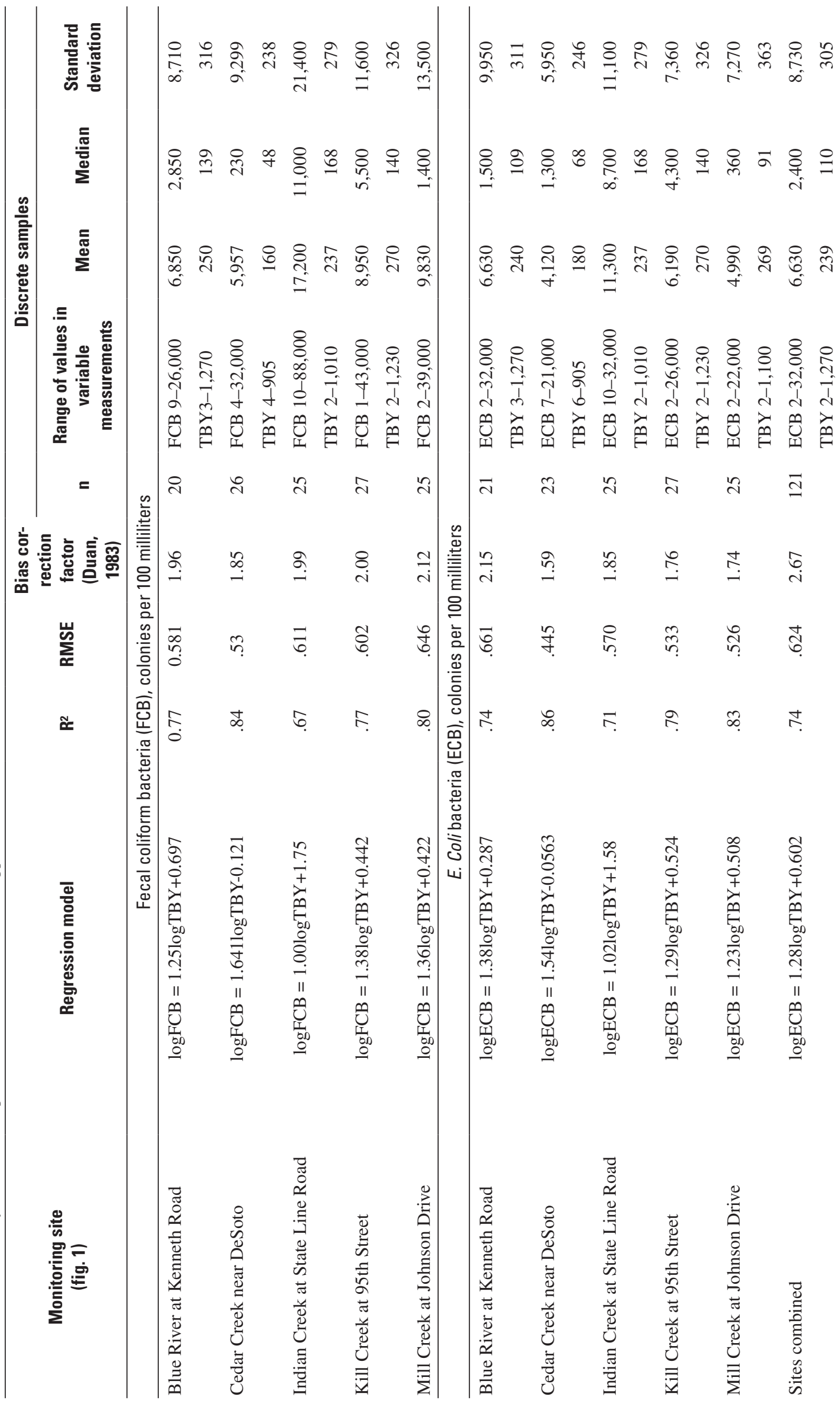




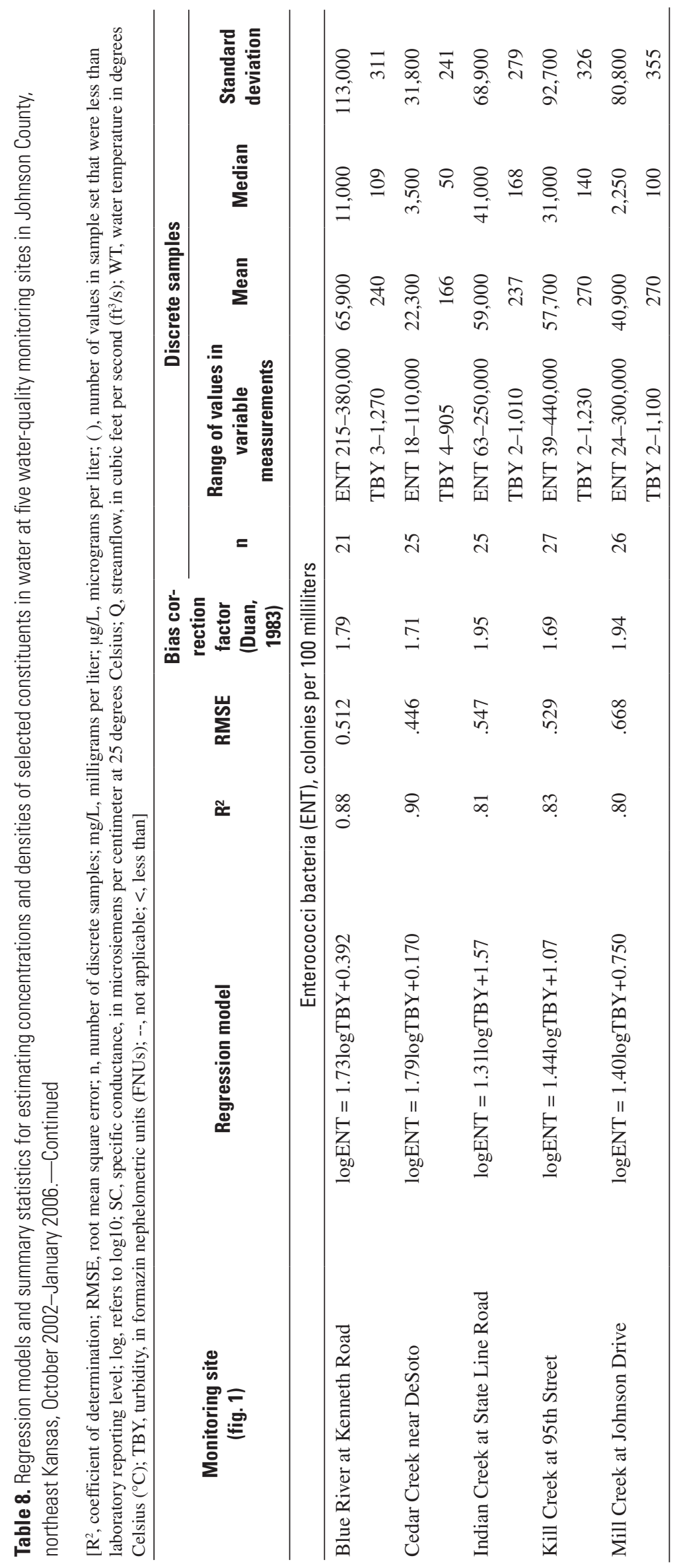


Regression models shown in table 9 demonstrate the statistical relations between suspended-sediment concentration and constituents often associated with particulates. Although strong relations exist for total suspended sediment and some indicator bacteria, relations with unfiltered (total) nutrients are weaker except at the Blue River site, and to a lesser extent the Kill Creek site, where nonpoint-source agricultural runoff is the primary source of nutrients. The trapping effects of impoundments may interfere with relations between sediment and nutrients in the Cedar Creek watershed. Nutrients originating from WWTFs at the Indian Creek site may result in poor relations with sediment at that site. These statistical relations have potential implications for implementation of BMPs demonstrating that if sediment concentrations are decreased, concentrations of sediment-associated constituents such as suspended solids, some nutrients, and bacteria also may decrease.

Graphs comparing the five site-specific models for suspended sediment, chloride, and E. coli indicator bacteria are shown in figure 14 and discussed in the relevant sections below. The 90-percent prediction intervals shown in figure 14 were calculated using a model with data from all sites combined; most of the model estimates fall within these boundaries.

\section{Regression-Estimated Constituents}

\section{Suspended Sediment and Total Suspended Solids}

Sediment in the water can reduce light penetration, smother benthic habitats, clog gill structures in fish, reduce photosynthesis, and interfere with water-treatment equipment (Devlin and McVay, 2001). Suspended sediment, particularly sediment composed of fine material (silt and clay), gives water a muddy appearance and provides attachment sites allowing accumulation and transport of nutrients, pesticides, and indicator bacteria (Jordan and Stamer, 1995). Sediment originates primarily from geology and surface soils, channel bank erosion, and streambed sediment re-suspended during stormflow. KDHE narrative criteria for suspended sediment state that artificial sources shall not interfere with aquatic life. Artificial sources include sources that result from human activities and may be minimized by construction of control structures, modification of operating practices, or restraint of activities (Kansas Department of Health and Environment, 2005).

Urbanization affects sediment supply and transport differently during construction and post-construction phases, as summarized by Paul and Meyer (2001). During the construction phases, erosion of exposed soils leads to larger sediment loads (Leopold, 1968). This effect intensifies in more sloped watersheds and generally occurs during a few large floods (Wolman, 1967). The increase in sediment supply leads to bed aggradation, and stream depths may decrease resulting in decreased channel capacity, larger floods, and overbank sediment deposition (Wolman, 1967). The aggradation phase is followed by an erosional phase, during which channel erosion is the largest source of sediment. Increases in impervious surface area substantially increase the frequency or volume of bankfull floods leading to a general deepening (incision) and widening of the channel (Booth, 1990). After incision, channels migrate laterally and bank erosion begins (Trimble, 1997). In developed urban streams, the majority of sediment being transported originates from channel erosion rather than hillside erosion (Trimble, 1997).

Suspended-sediment concentration (SSC) and total suspended solids (TSS) are the two terms typically used to quantify concentrations of suspended solid-phase material in surface water. Although the terms are sometimes used interchangeably, the laboratory analytical methods differ and may produce considerably different results, particularly when samples contain sand-sized material (Gray and others, 2000). The SSC method is preferred for quantifying solids in natural water samples because it has been found to be more reliable than the TSS method, which was originally designed for analysis of wastewater samples (Gray and others, 2000). However, TSS is sometimes used in regulatory applications such as TMDLs and NPDES permits. For example, the Mill Creek TMDL for biological impairment (Kansas Department of Health and Environment, 2007) identifies large sediment load and particularly TSS as a cause of biological impairment. The TMDL establishes a goal of 35 percent reduction in average TSS concentrations during the biologically active season. Although regression models were developed for both SSC and TSS (table 8), more emphasis is placed on the SSC models in this report.

Regression models for SSC (table 8) were among those with the least uncertainty, as indicated by $\mathrm{R}^{2}$ values equal to or larger than 0.95, RMSE values less than about 0.2, and evenly distributed residual plots (not shown). All SSC models used turbidity as the only explanatory variable. The regression lines are similar when compared between sites (fig. 14A) although the Mill Creek model has a slightly smaller slope than the other models indicating that sources of suspended sediment and turbidity might differ slightly from other sites. Different sources of sediment likely are caused by construction in urbanizing parts of the Mill Creek watershed. The models were developed using suspended-sediment concentrations in discrete samples ranging from less than $10 \mathrm{mg} / \mathrm{L}$ to greater than 2,000 $\mathrm{mg} / \mathrm{L}$ at each site with a maximum of $4,170 \mathrm{mg} / \mathrm{L}$ at the Blue River site (table 8). In-stream turbidity in regression models ranged from about 5 FNUs to greater than 1,000 FNUs at all sites except Cedar which had a maximum of 905 FNUs (table 8).

Continuous estimates of suspended-sediment concentration in 2005-06 ranged from a minimum of less than $3 \mathrm{mg} / \mathrm{L}$ at all sites, to a maximum of $4,600 \mathrm{mg} / \mathrm{L}$ at the Cedar Creek site in 2005 and the Blue River site in 2006 (table 10). The other sites may have had suspended-sediment concentrations as large as Cedar Creek, but 


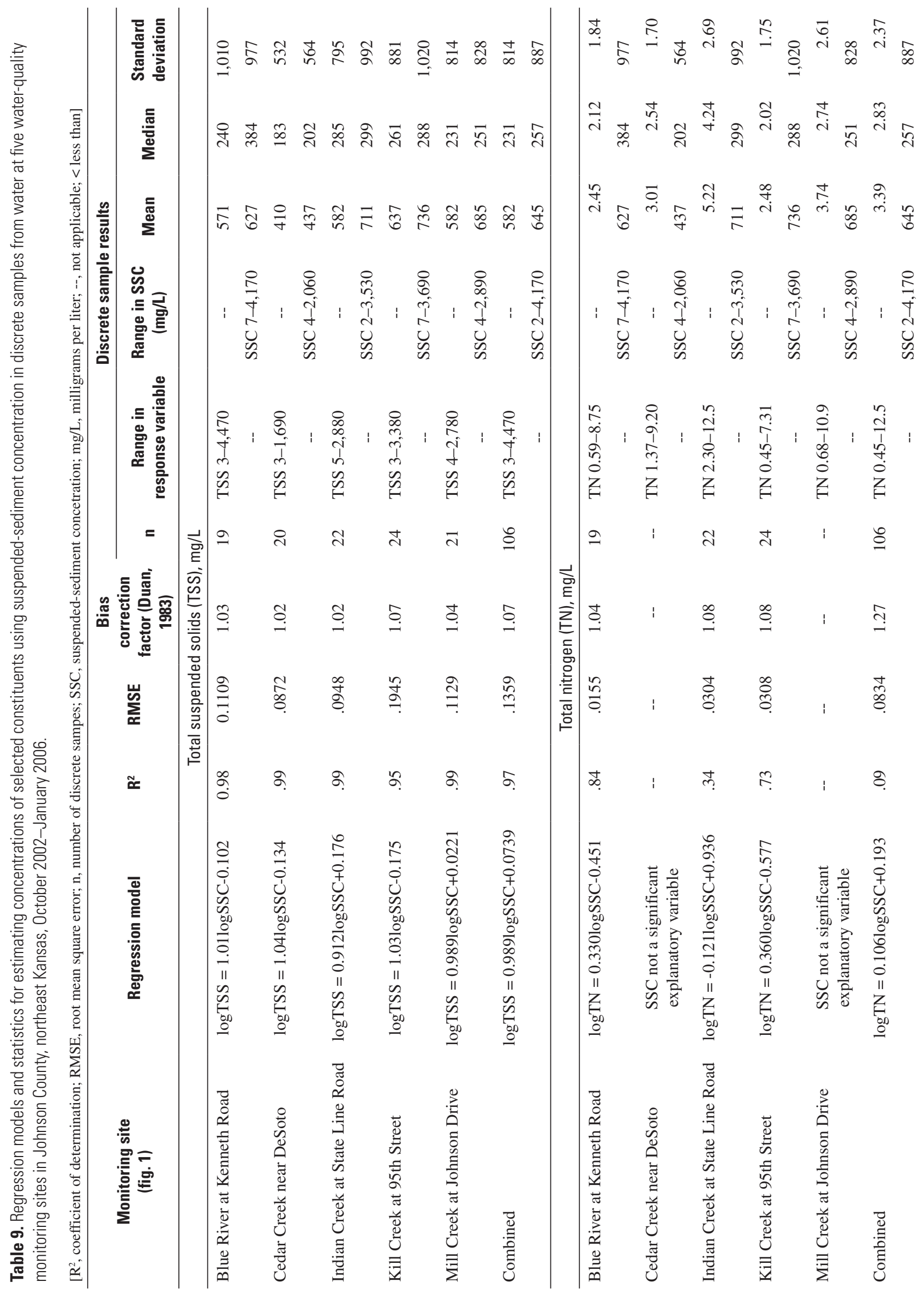




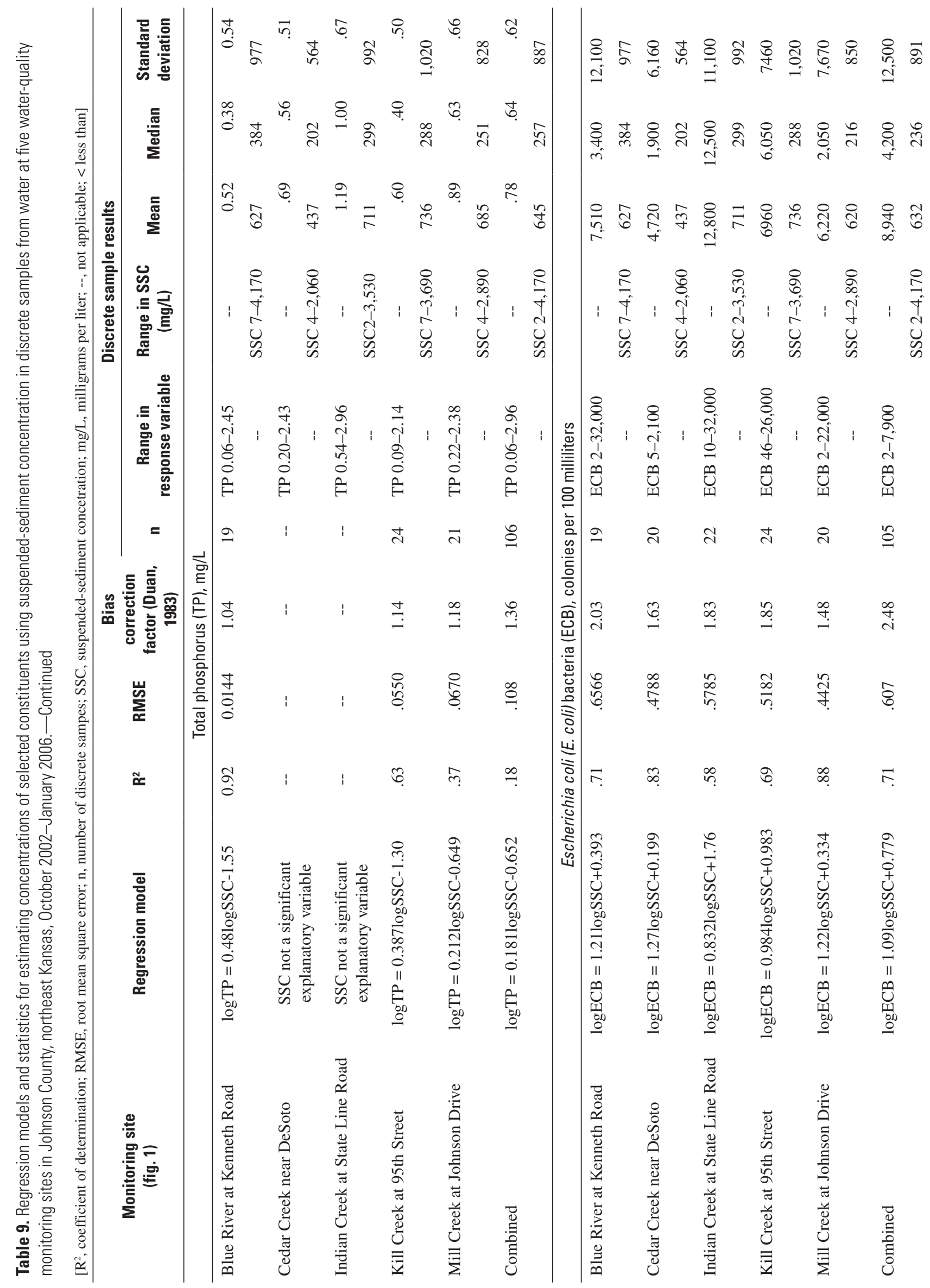




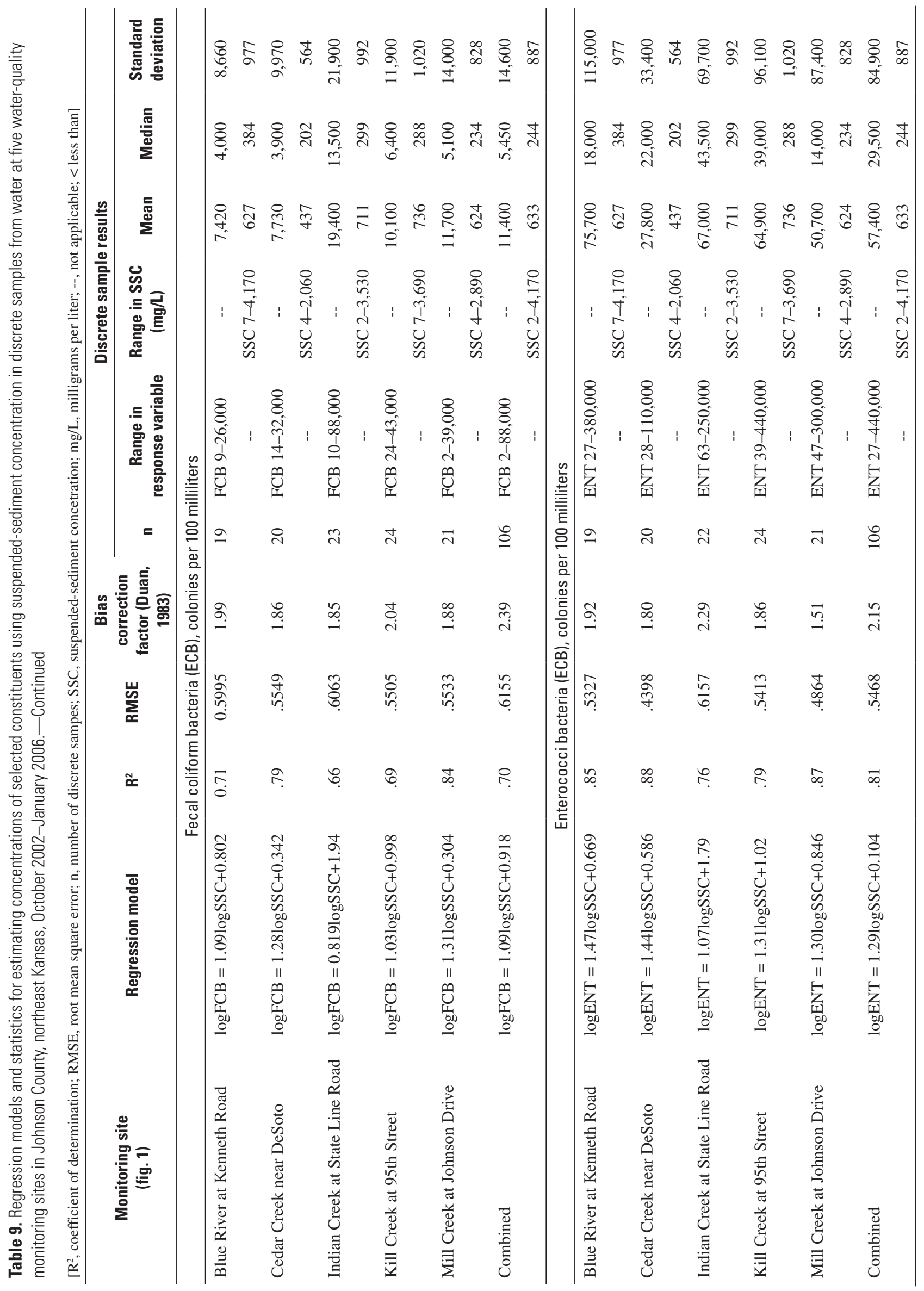




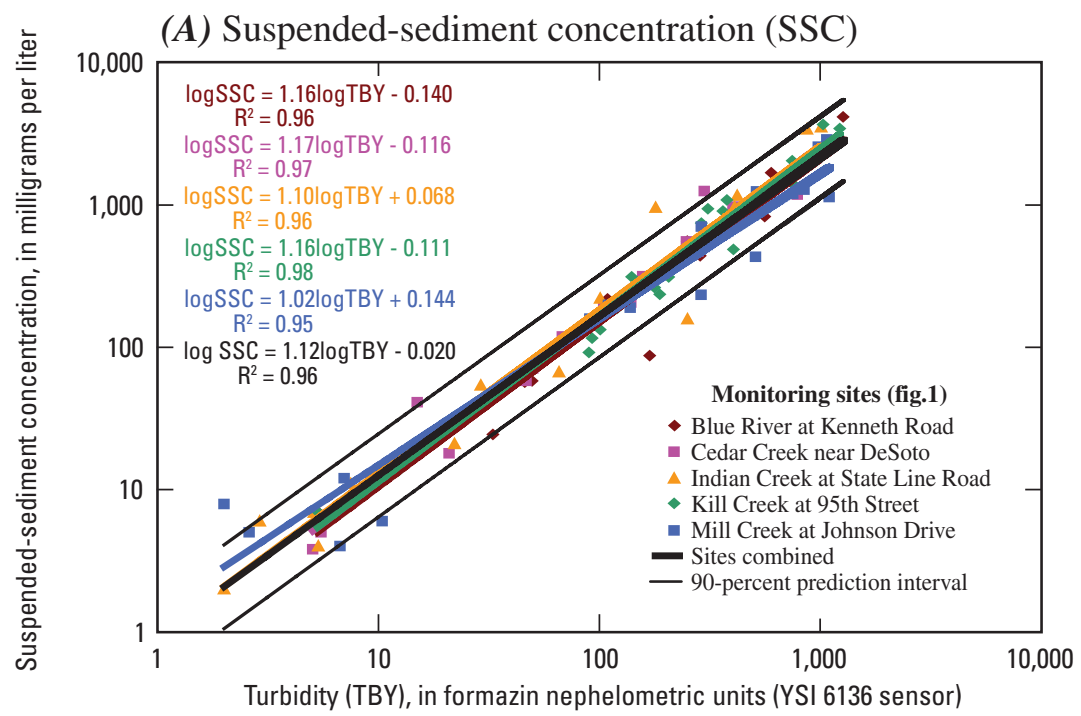

(B) Chloride $(\mathrm{Cl})$

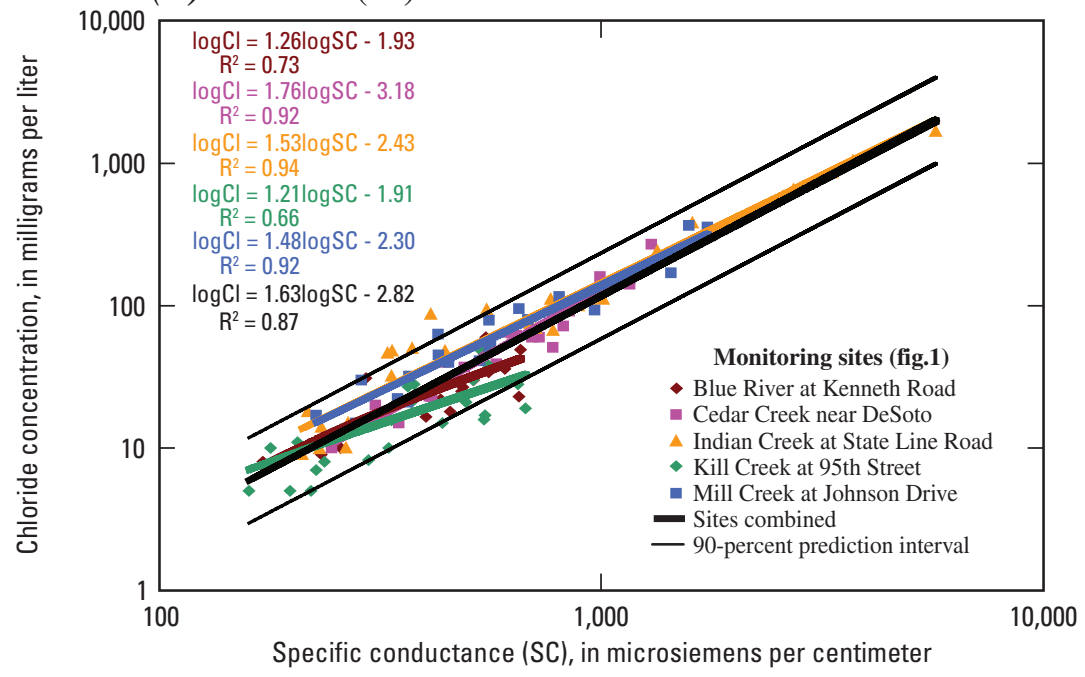

(C) Escherichia coli bacteria (ECB)

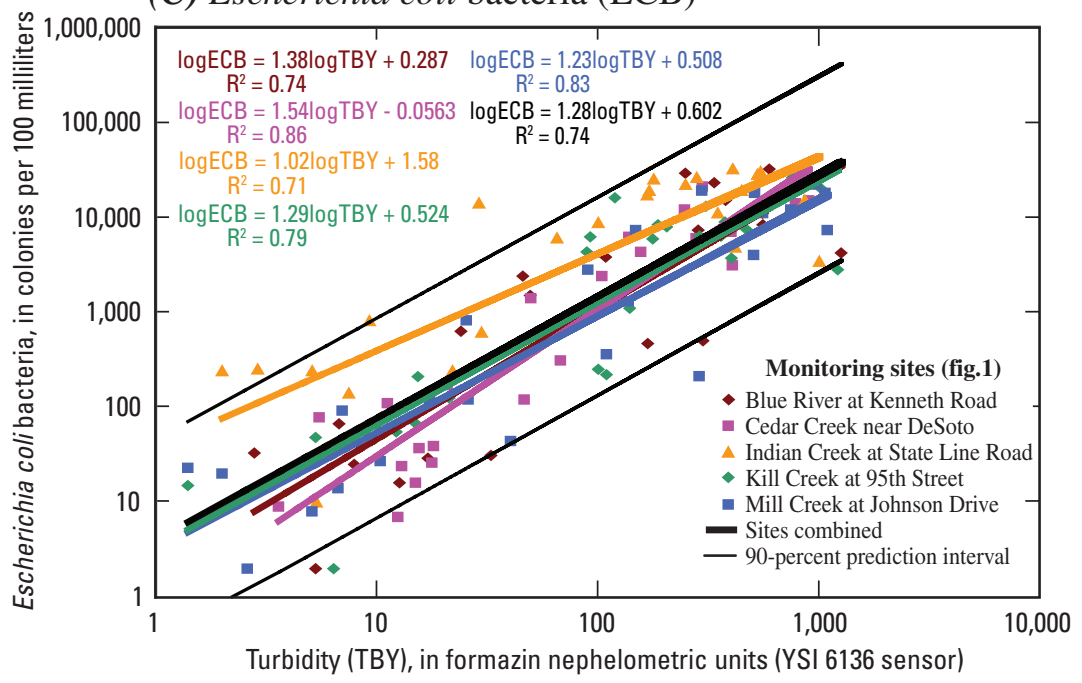

Figure 14. Comparison of explanatory ( $x$-axis) and response (y-axis) variables for selected water-quality constituent regression models for $(A)$ suspended-sediment concentration, (B) chloride, and (C) Escherichia coli bacteria. 


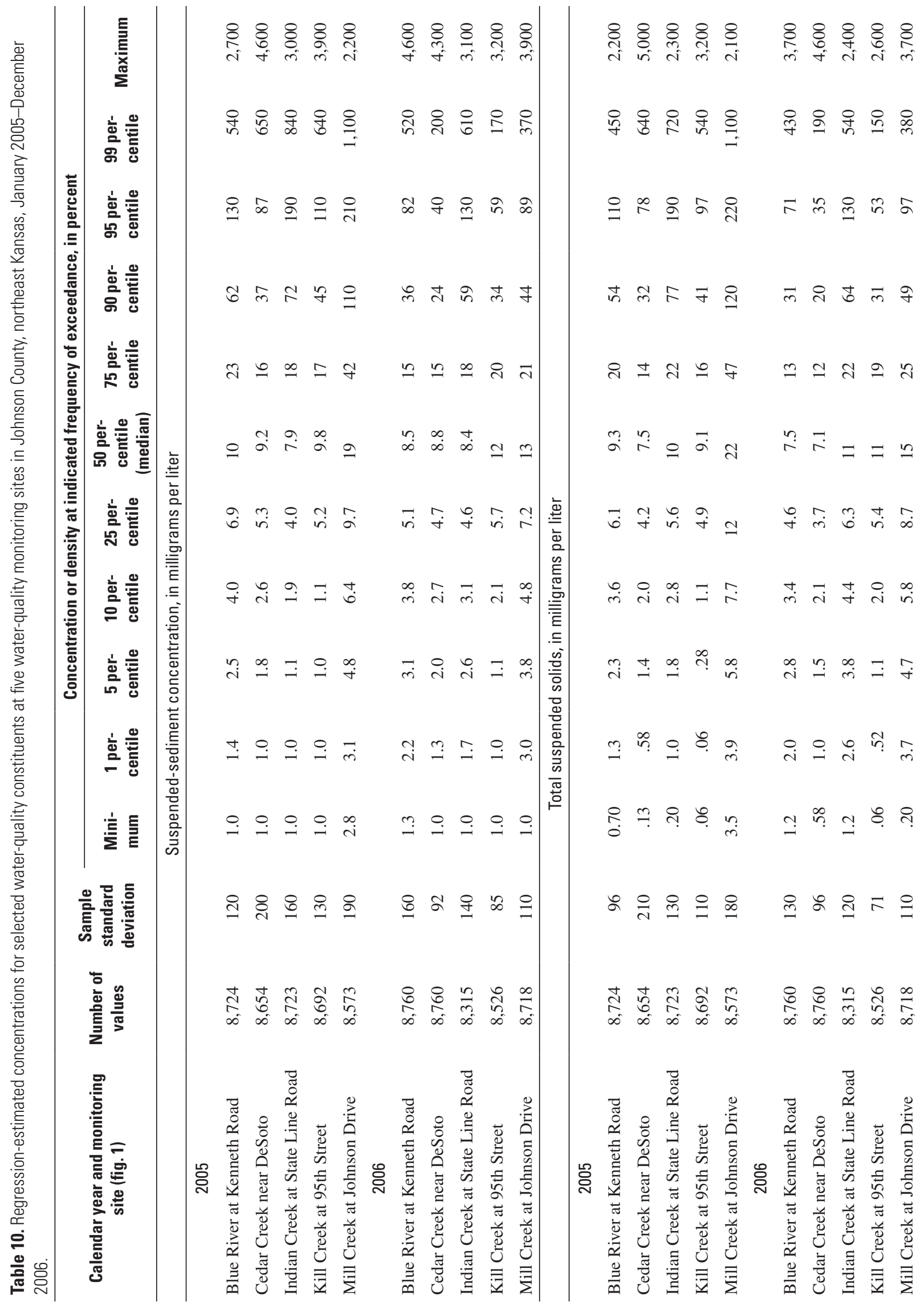




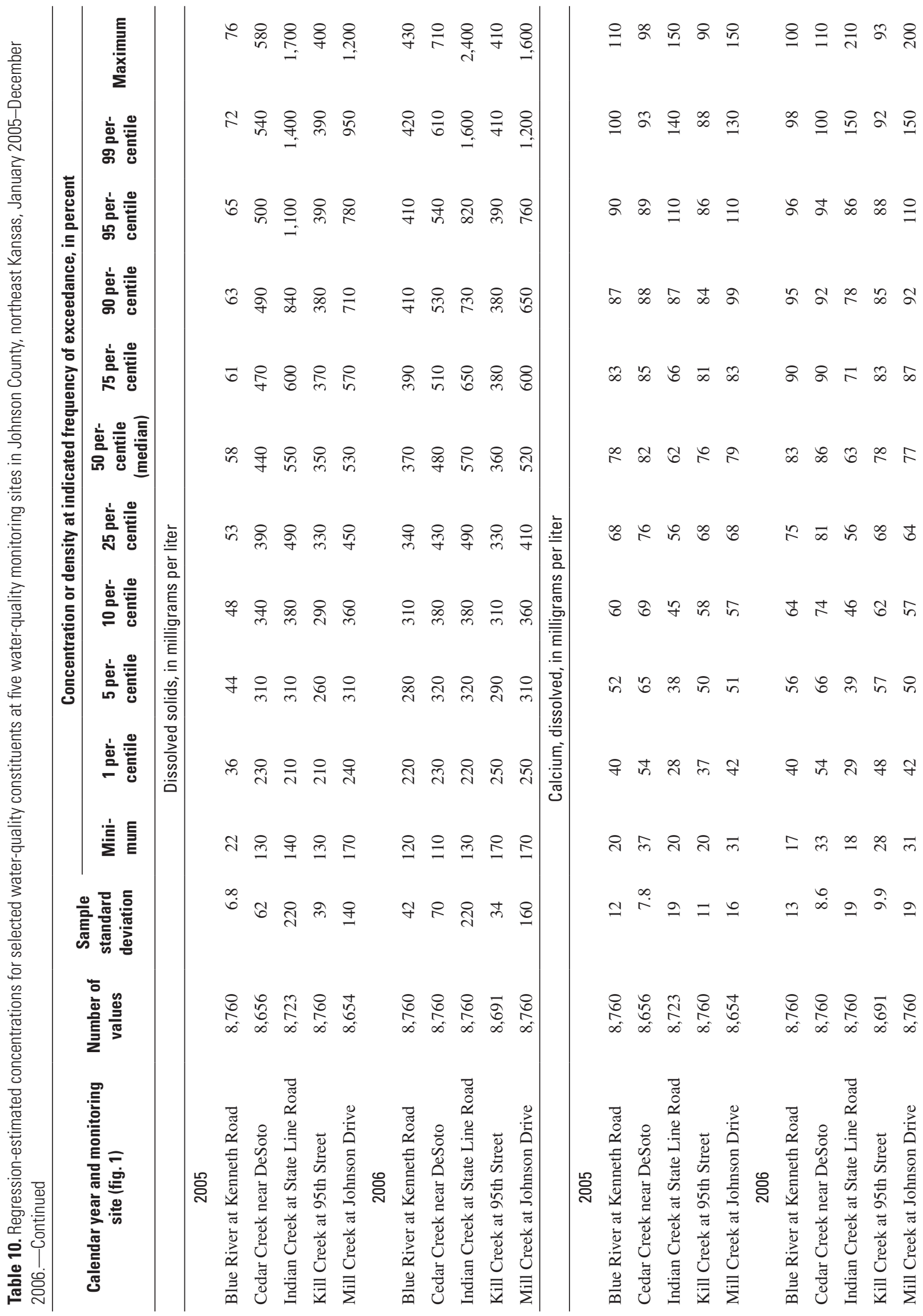




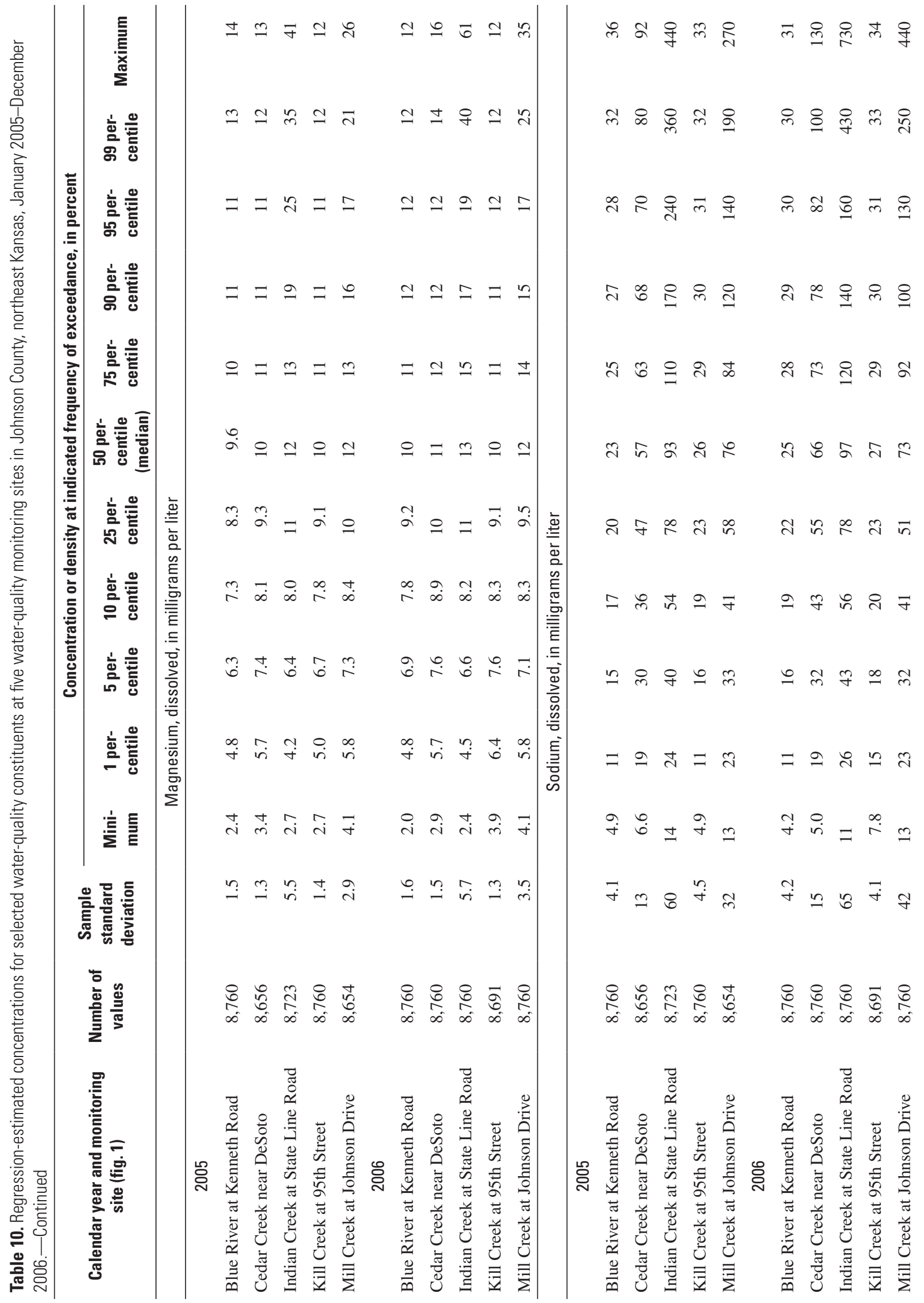




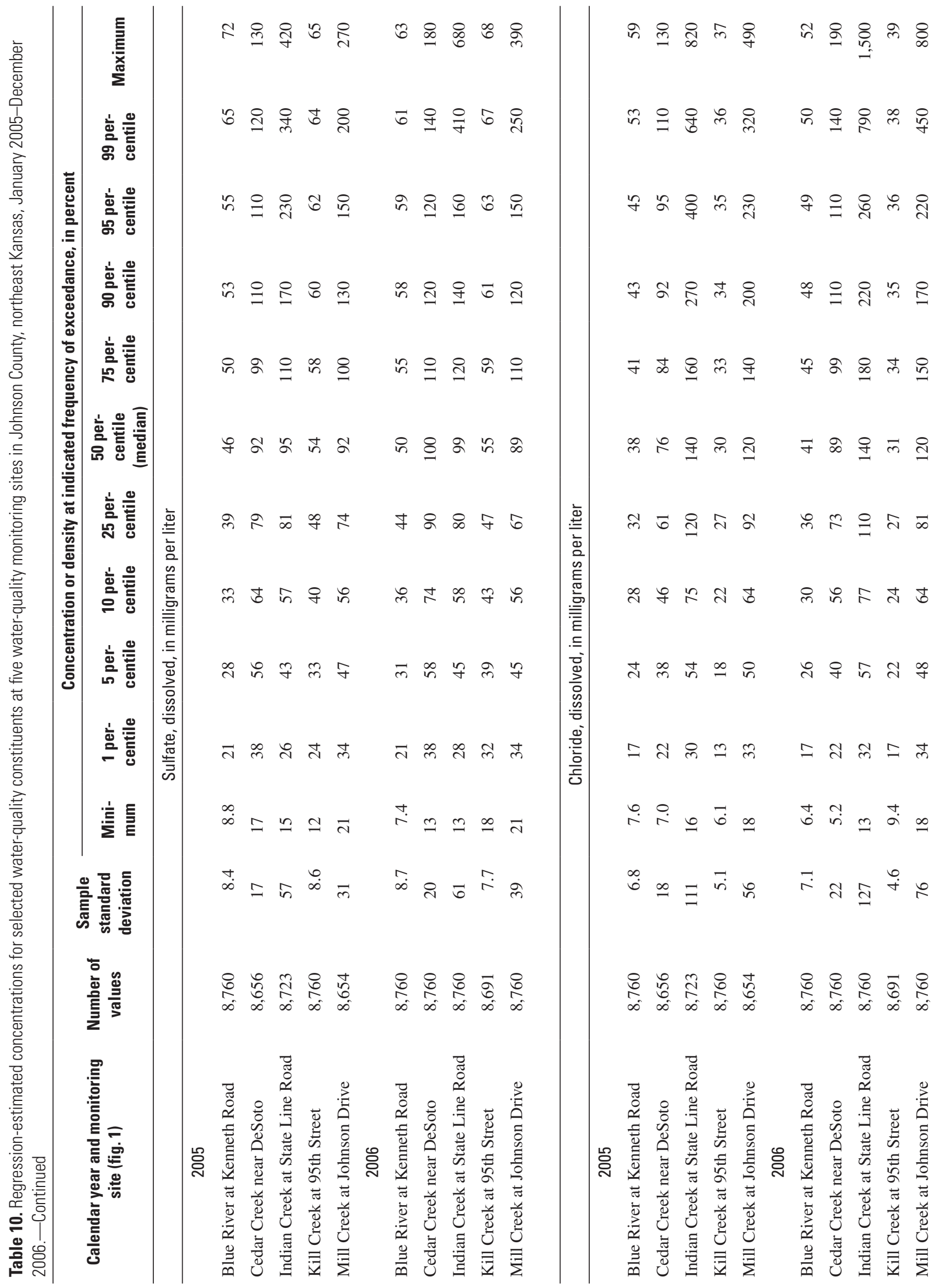




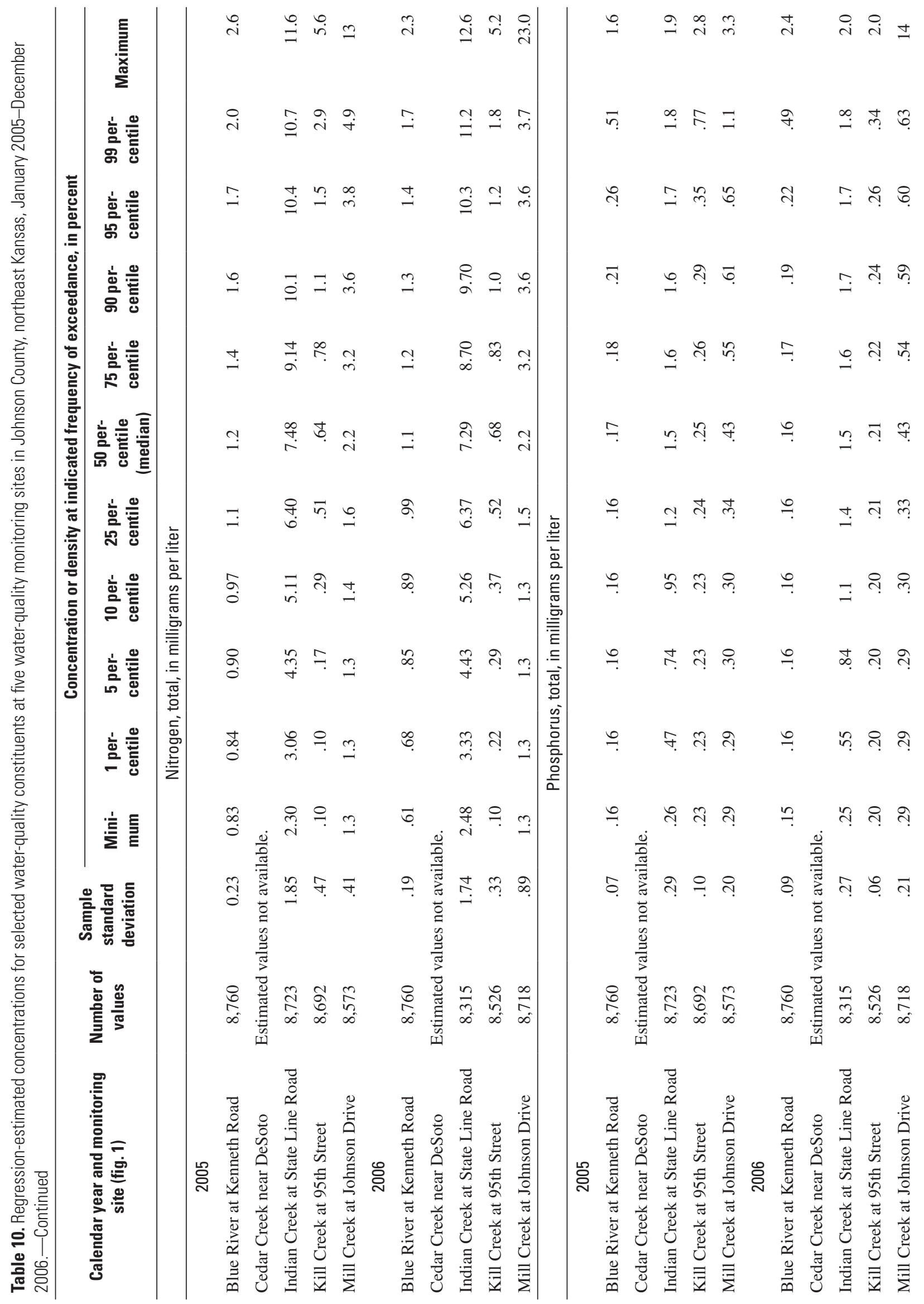




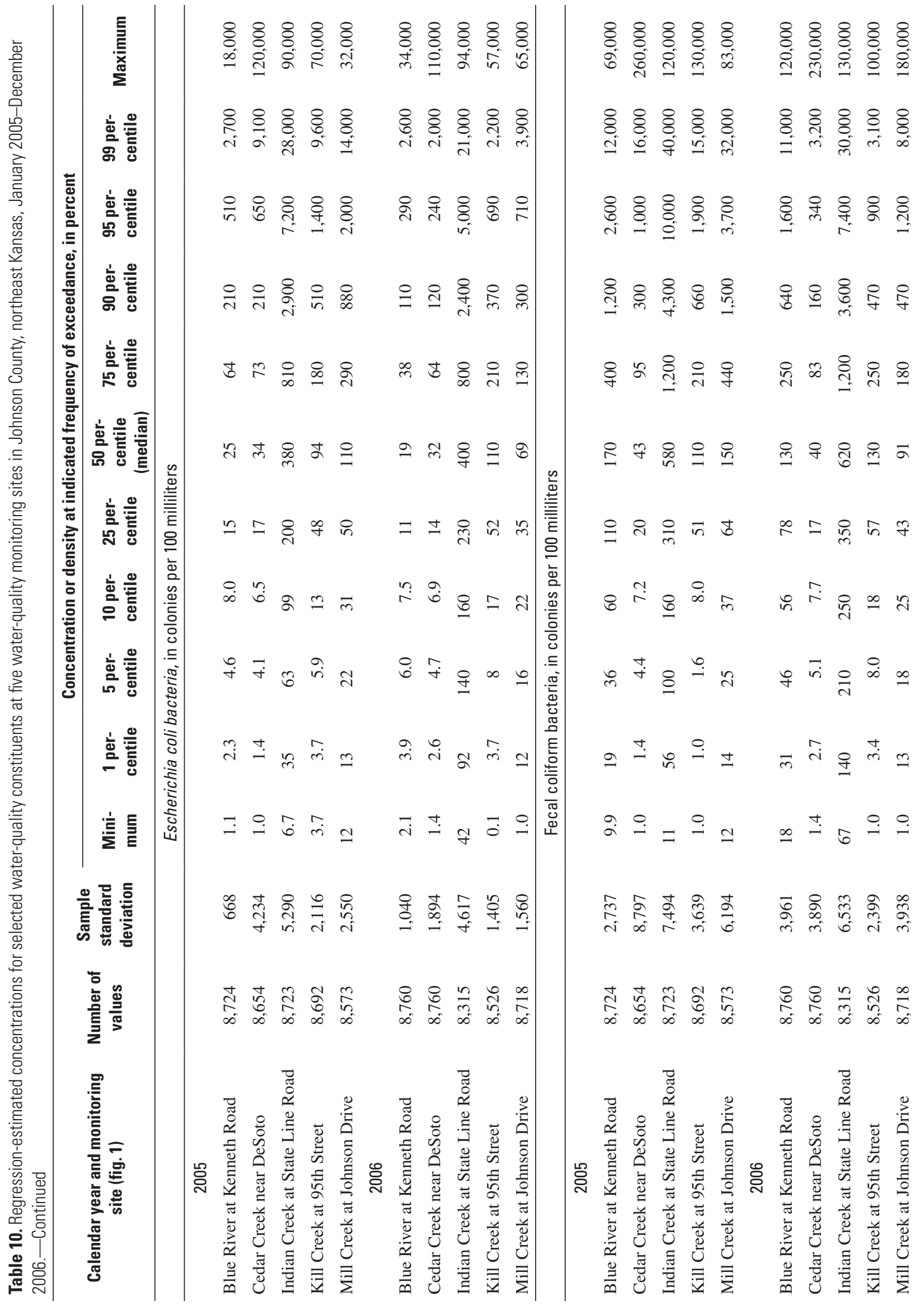




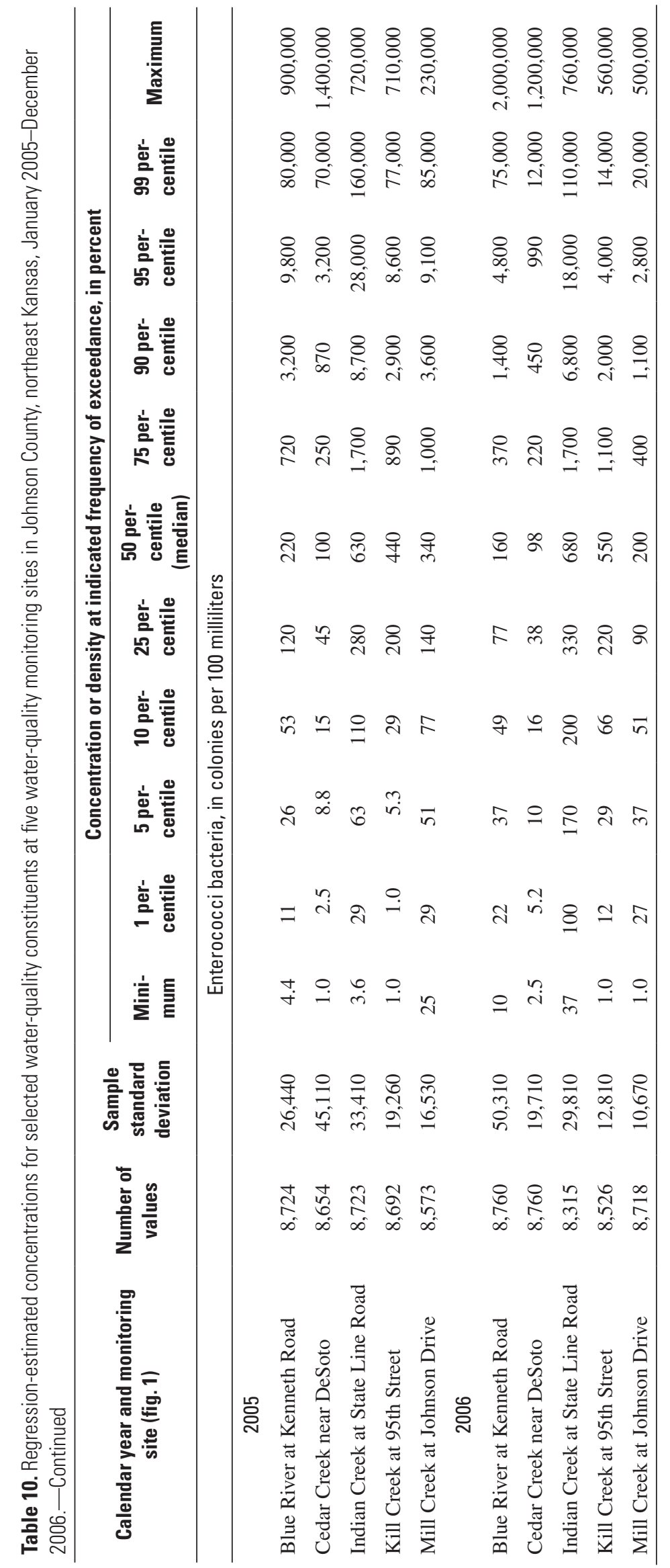


different maximum measurement on turbidity sensors may have prevented larger readings. The largest median concentration for any year occurred at the Mill Creek site in 2005 (19 mg/L) where the median was nearly double that of the other four sites (7.9-10 mg/L). Suspended-sediment concentration was nearly always largest at the Mill Creek site (fig. 15). The Mill Creek watershed is undergoing rapid development that likely is contributing to larger sustained sediment concentrations. About 70 percent of the time, the smallest sediment concentration occurred at the Indian Creek site (fig. 15), in part because most of the streamflow at this site originated from treated WWTF discharge just upstream (Lee and others, 2005).

Estimated annual suspended sediment loads and yields were largest at the Indian Creek site, and annual loads were smallest at the Kill Creek site (table 11, fig. 16). Most of the time between January 2005 and December 2006, the hourly sediment load was larger at the Indian and Mill Creek sites (fig. 17, table 12), which carry larger streamflow volumes. The estimated annual sediment load at all sites was larger in 2005 than in 2006 by 33 (Indian Creek) to 750 percent (Kill Creek; table 11). Annual differences can be attributed to differences in precipitation and streamflow both of which were larger in 2005 (table 6).

At least 90 percent of the total annual load in 2005-06 at all sites occurred during less than 2 percent of the time (fig. 18), generally corresponding with the largest streamflow.
The streamflow that was exceeded less than 2 percent of the time at the monitoring sites ranged from about $250 \mathrm{ft}^{3} / \mathrm{s}$ at the Cedar and Kill Creek sites to about $1,000 \mathrm{ft}^{3} / \mathrm{s}$ at the Indian Creek site (fig. 4). Therefore, management practices designed to control sediment during typical streamflows rather than infrequent large streamflow will have minimal effect on total annual loads. During the 3- to 4-year period of record for the five monitoring sites, streamflow has only slightly exceeded the estimated 2-year peak streamflow (Perry and others, 2004) at all sites except the Cedar and Kill Creek sites where streamflow has not exceeded the 2-year peak since monitoring began (fig. 19). Therefore, sediment load contributions when the 2-year streamflow is exceeded have not been well documented but are expected to be even larger than loads measured during this study period. Without continuous water-quality monitoring and load estimation, variations in loads corresponding with rapidly changing streamflow conditions would not be documented. Long-term monitoring makes it possible to assess both changes in streamflow and changes in sediment concentrations and loads and may make it possible to relate changes to implemented BMPs.

Individual runoff occurrences were examined for relative sediment load contributions and hysteresis patterns to improve characterization of sediment transport within each watershed. In June 2005, a single runoff period on the Blue River that included a peak streamflow of $9,840 \mathrm{ft}^{3} / \mathrm{s}$ (between the estimated 2-year peak streamflow of $6,570 \mathrm{ft}^{3} / \mathrm{s}$ and the 5-year

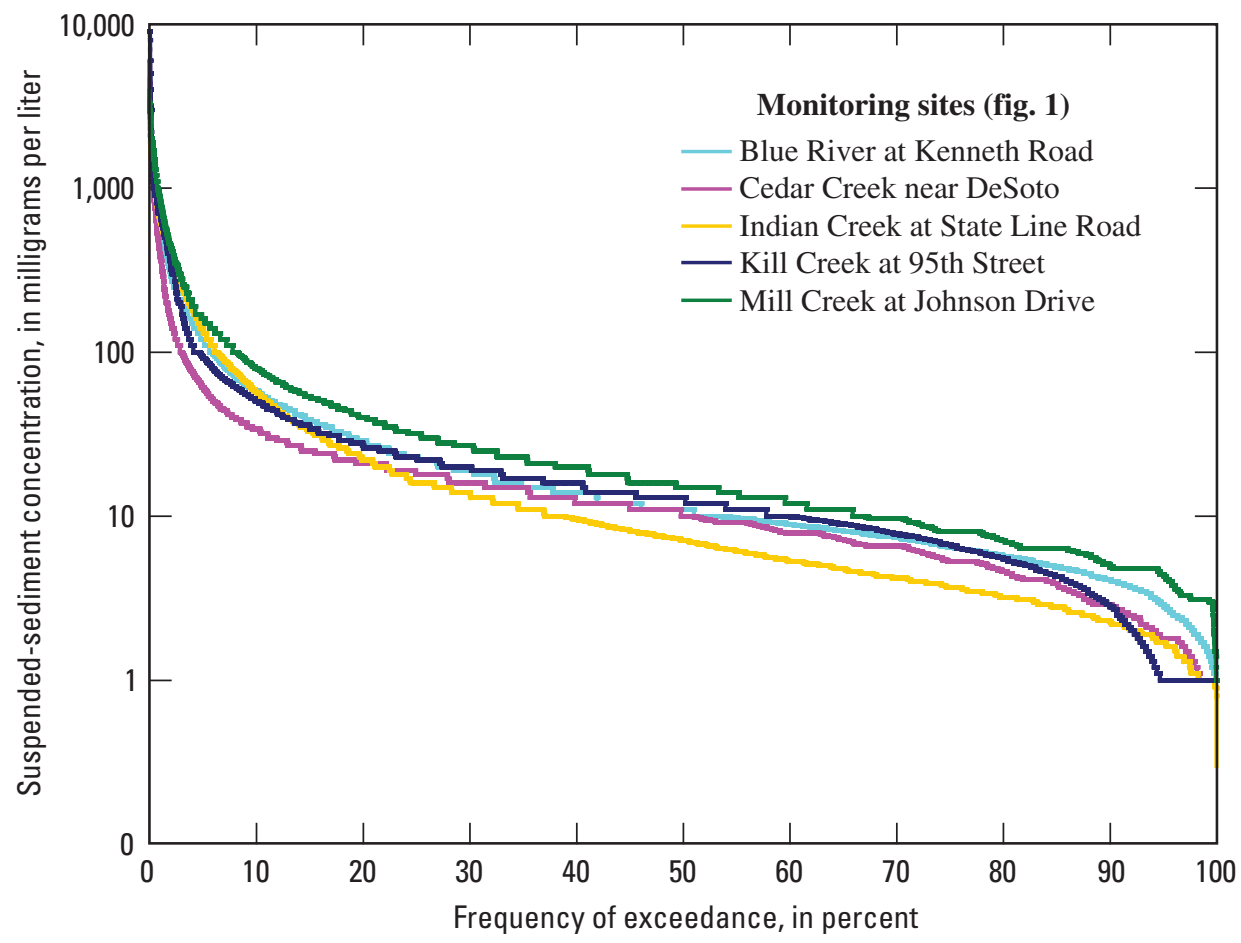

Figure 15. Duration curves for estimated suspended-sediment concentration at five water-quality monitoring sites in Johnson County, Kansas, March 2004-December 2006. 


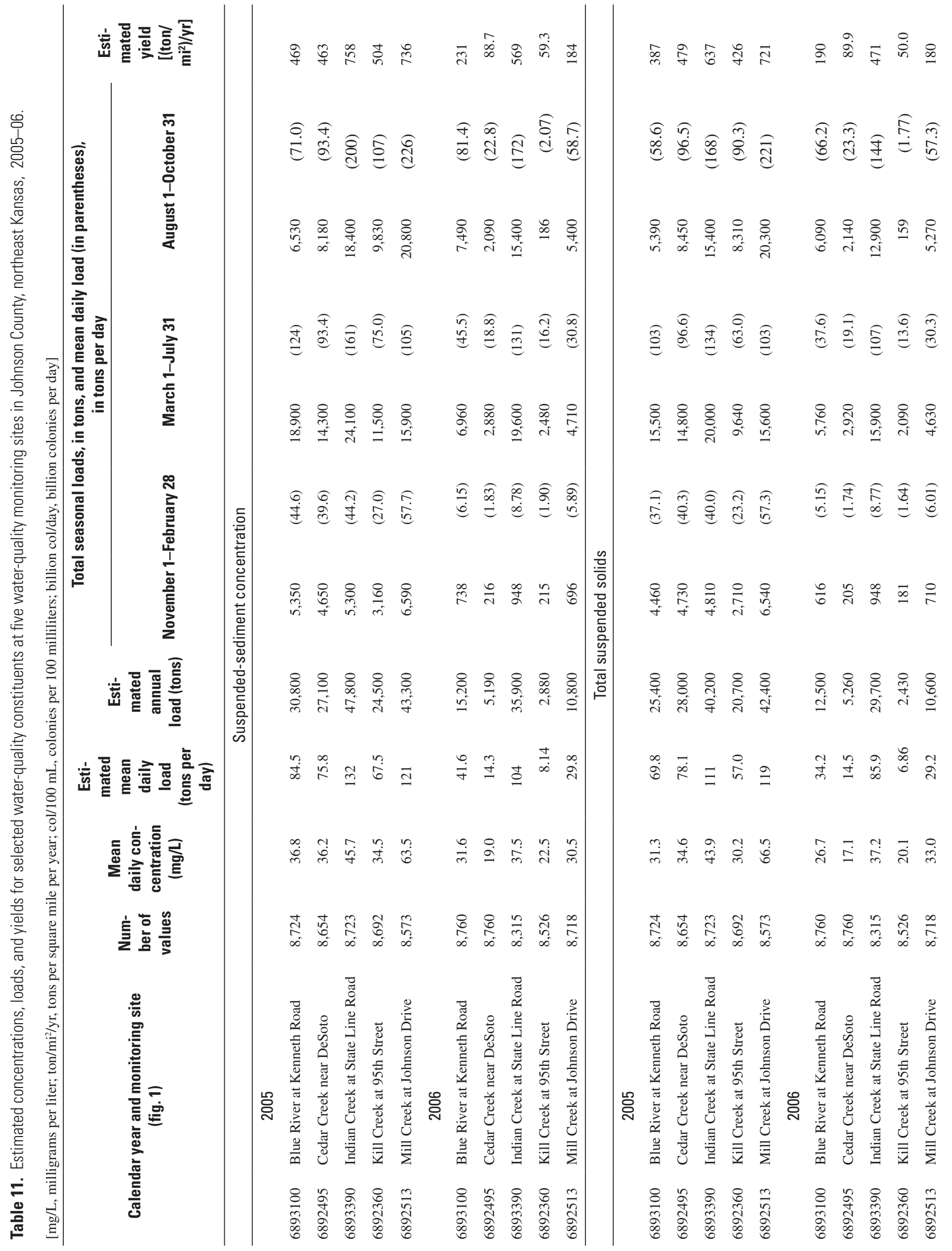




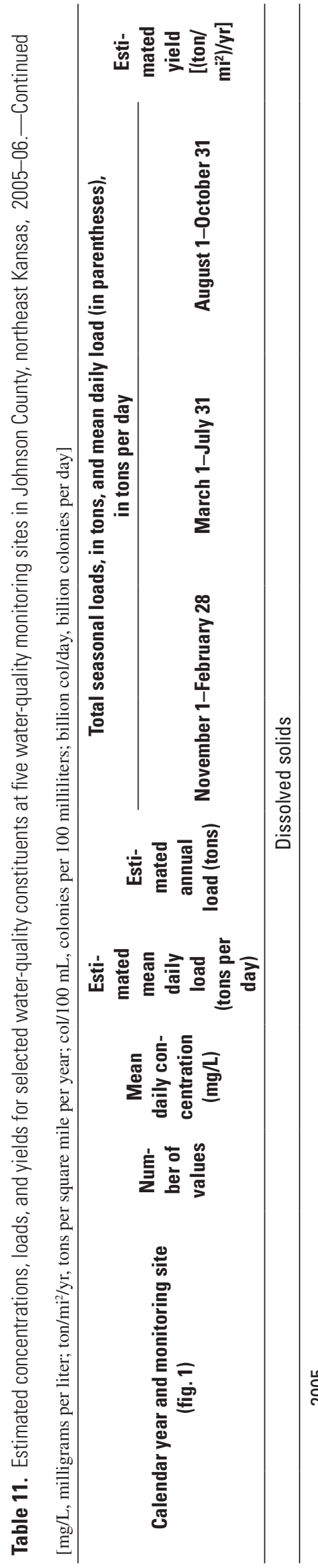

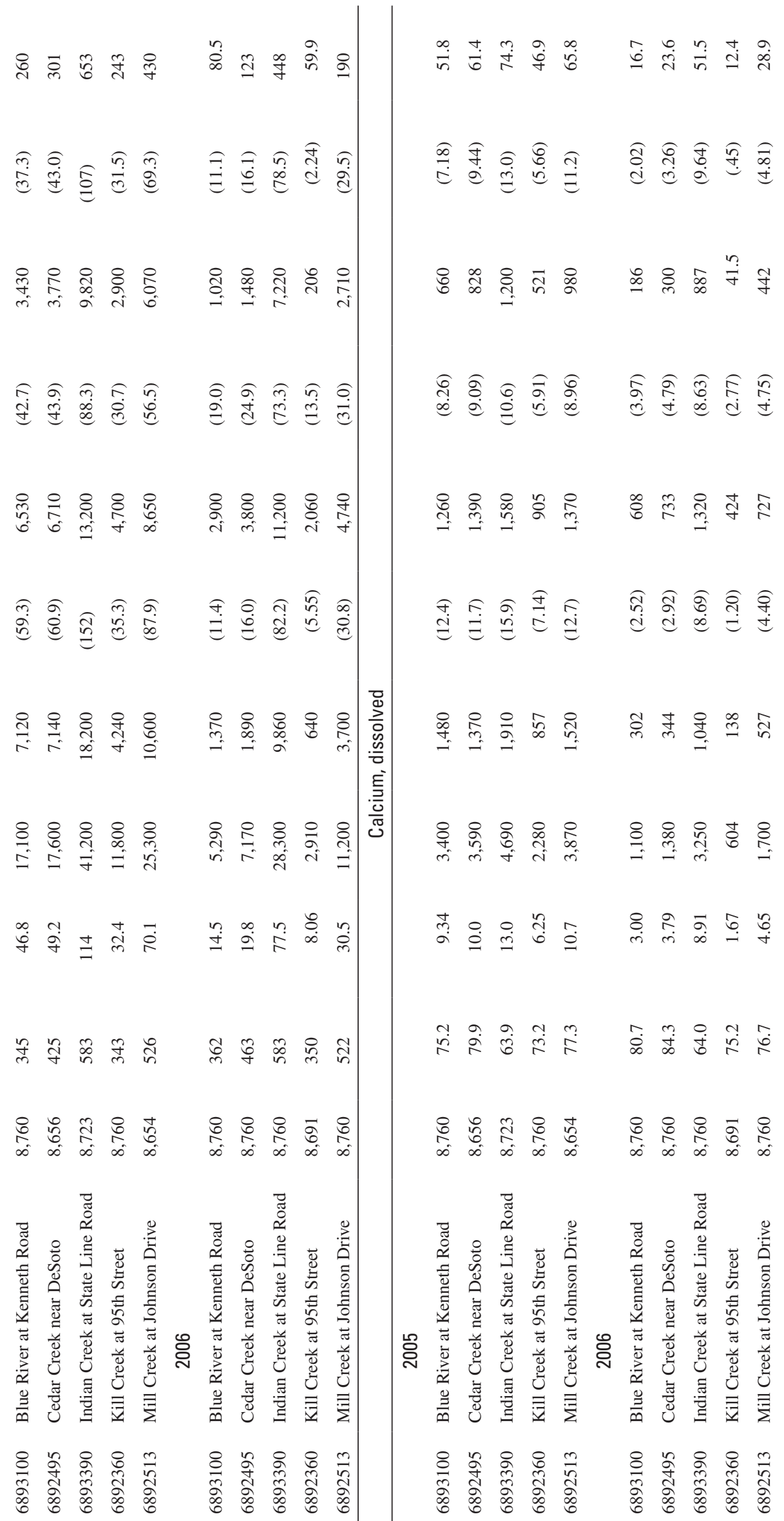




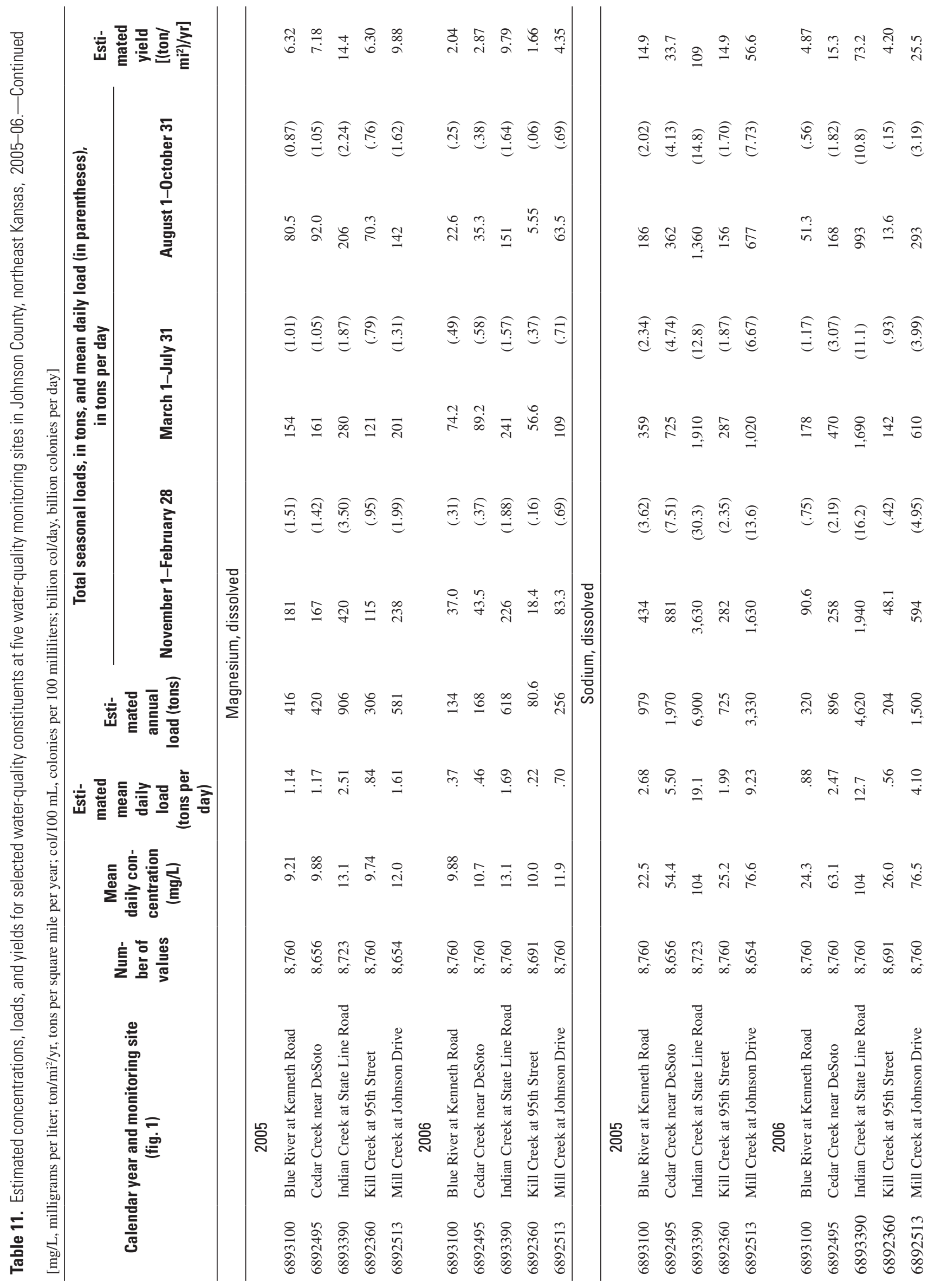




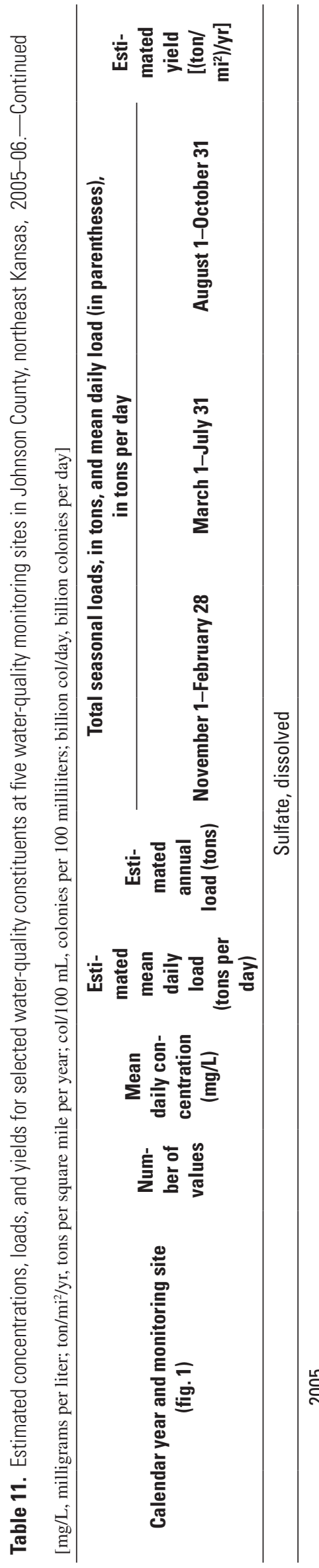

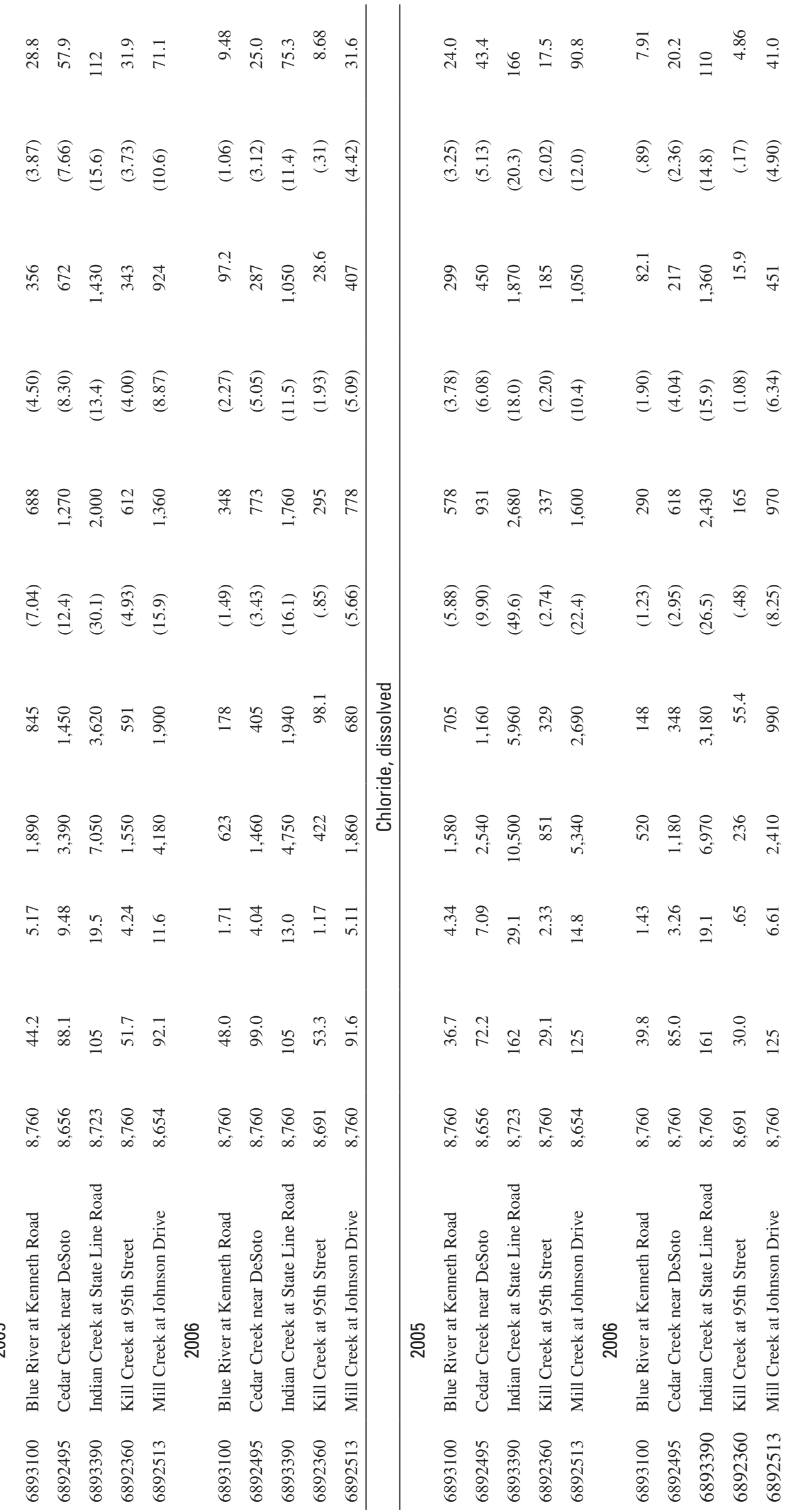




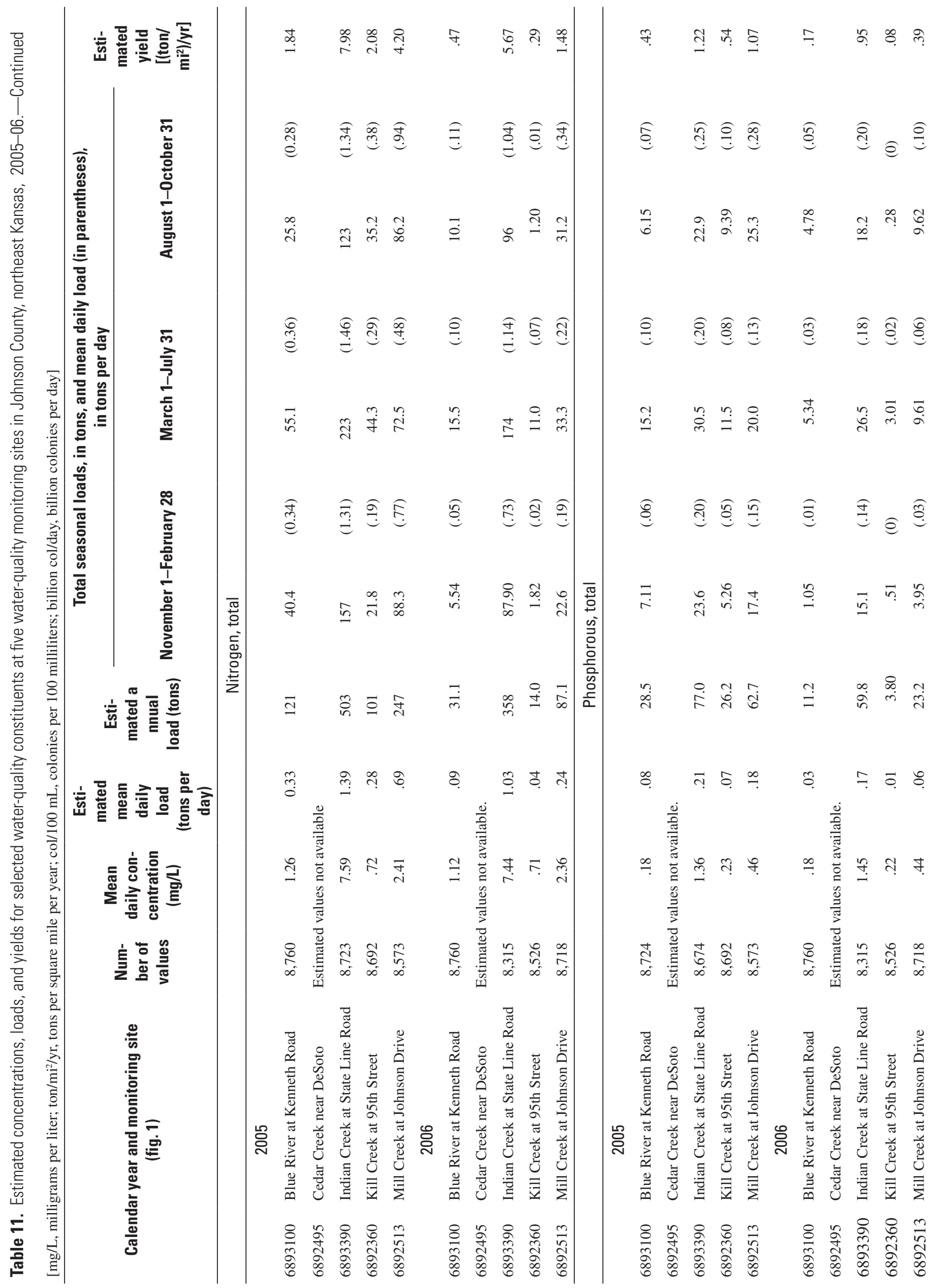




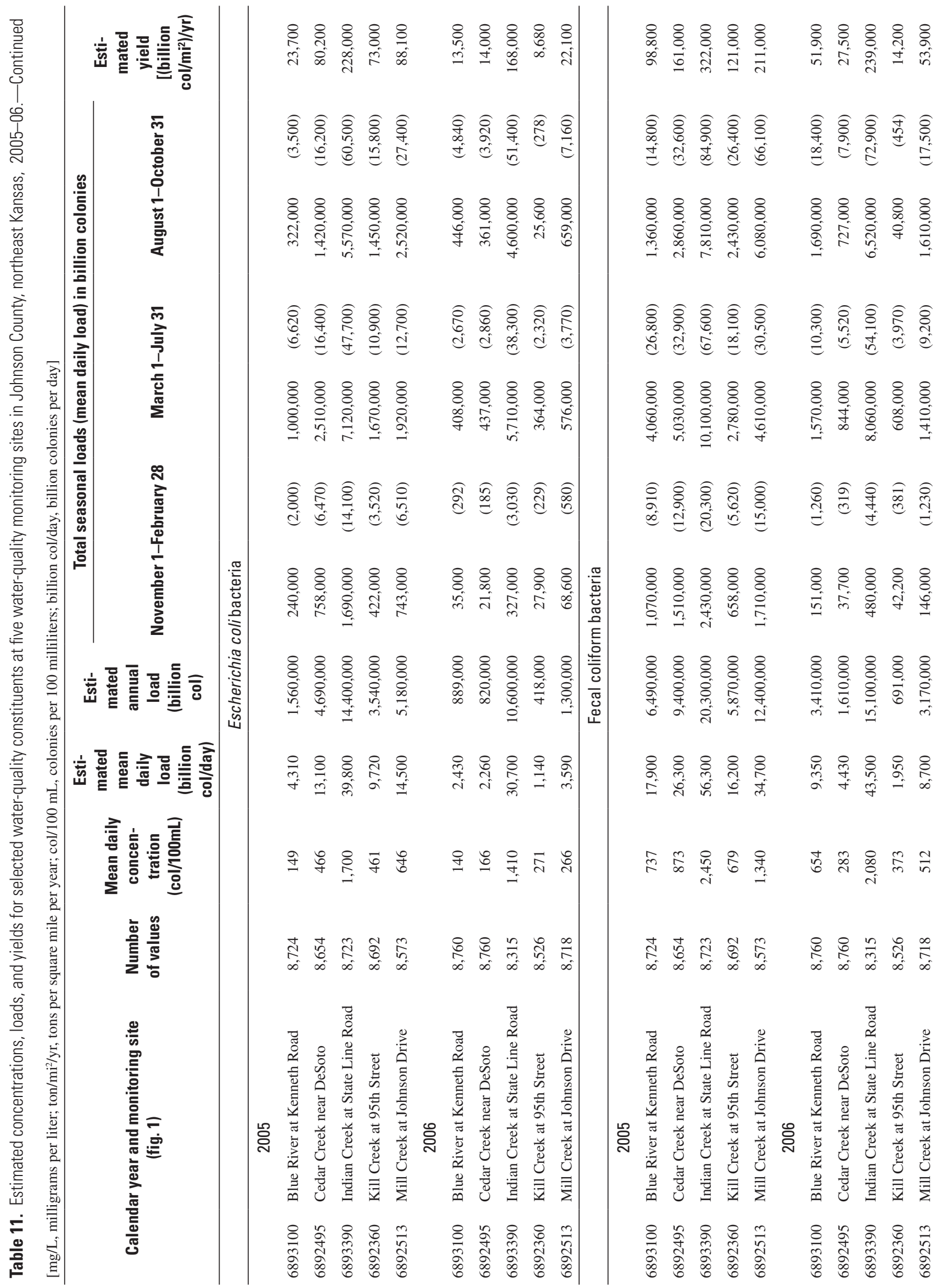




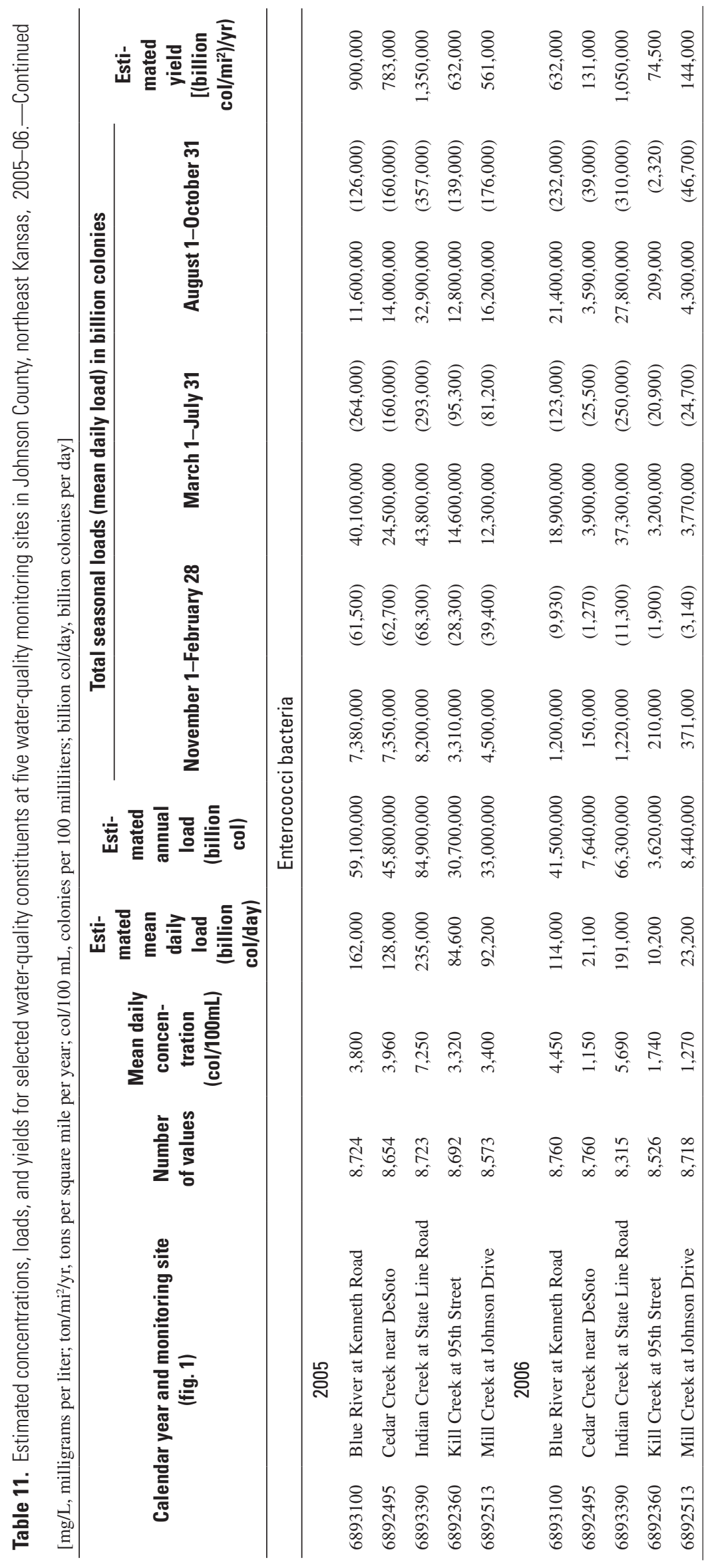



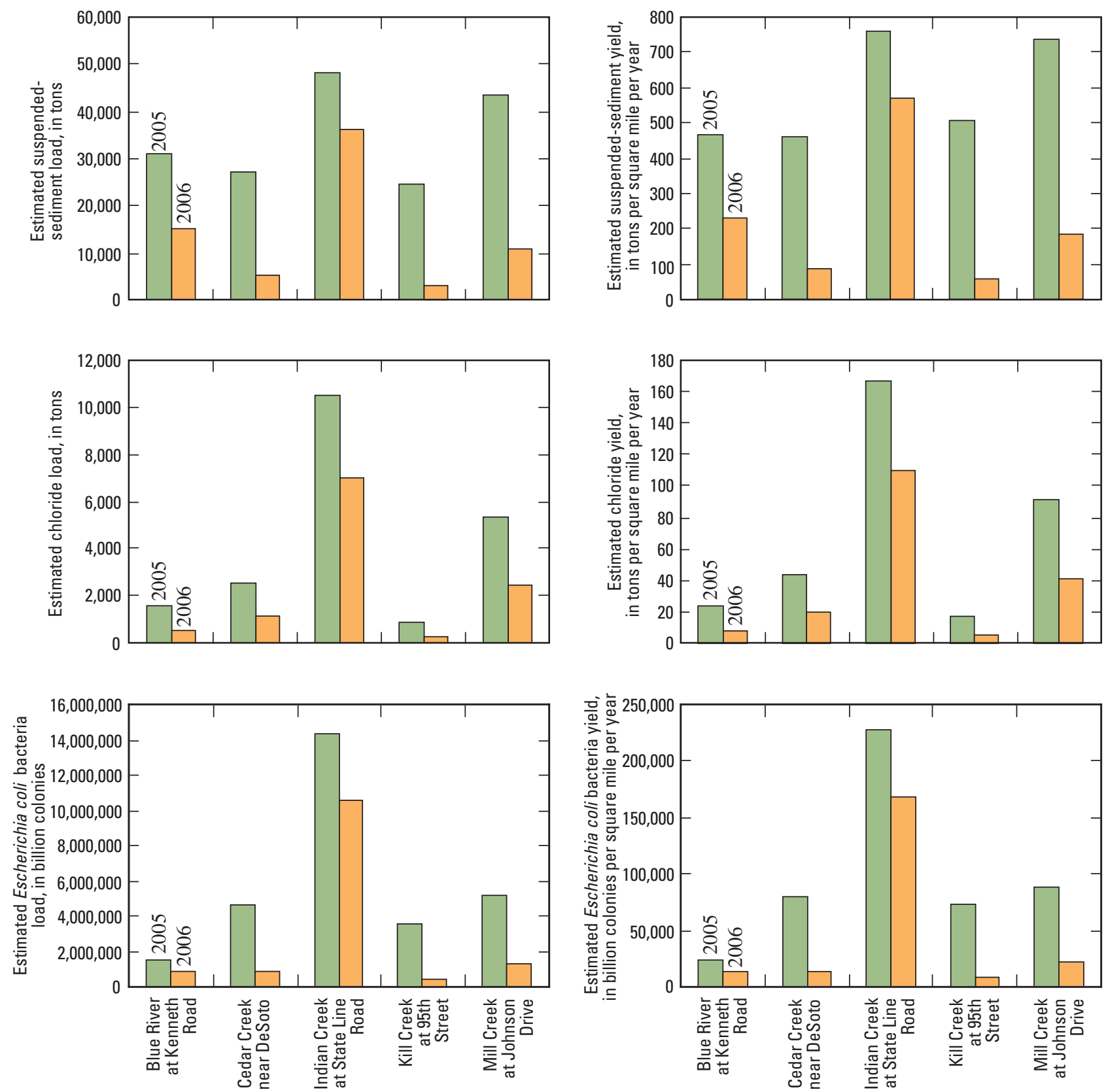

Monitoring sites (fig. 1)

Figure 16. Estimated annual loads and yields for suspended sediment, chloride, and Escherichia coli bacteria at five water-quality monitoring sites in Johnson County, Kansas, 2005-06. 


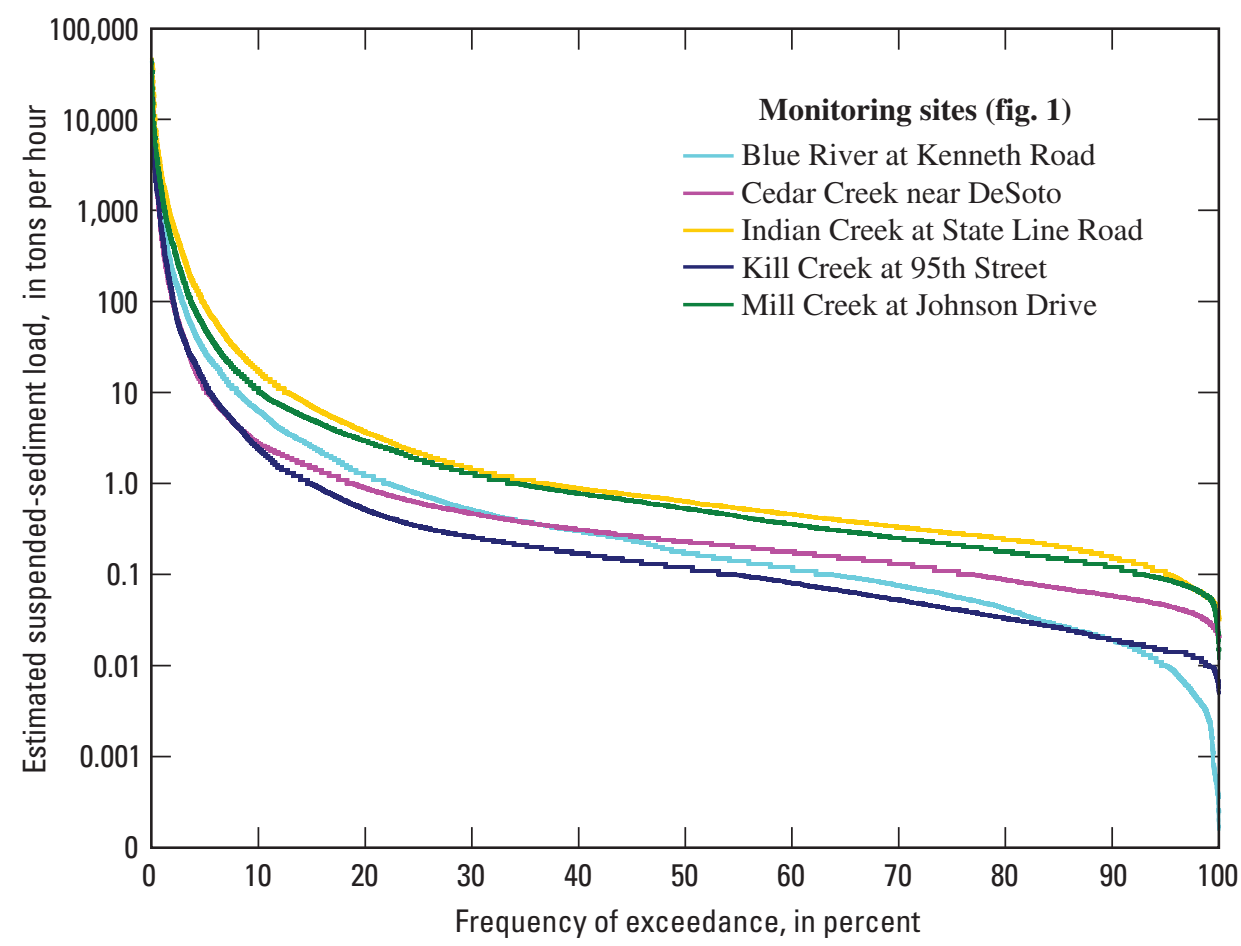

Figure 17. Duration curves for estimated suspended-sediment load at five water-quality monitoring sites in Johnson County, Kansas, January 2005-December 2006.

estimated peak streamflow of $11,600 \mathrm{ft}^{3} / \mathrm{s}$ ) on the Blue River lasted about 3 days but contributed more than 50 percent of the total annual suspended-sediment load (fig. 20, table 13). Therefore, about 50 percent of the 2005 sediment load at the Blue River site occurred during less than 1 percent of the time. Similarly, a June 2005 storm runoff lasting about 4 days on Kill Creek contributed 42 percent of the annual sediment load (table 13). The associated peak streamflow was $5,820 \mathrm{ft}^{3} / \mathrm{s}$, which was less than the estimated 2-year streamflow of $6,470 \mathrm{ft}^{3} / \mathrm{s}$. Approximately 80 percent of the total annual sediment load in 2005 at the Kill Creek site occurred during four periods of runoff totaling about 10 days. A 2.4-day runoff at the Indian Creek site in June 2005 contributed about 30 percent of the total annual suspended-sediment load while reaching a peak streamflow of $10,500 \mathrm{ft}^{3} / \mathrm{s}$, approximately equal to the estimated 5-year peak streamflow. Five of 10 runoff periods at the Indian Creek site that exceeded 1,000 ft $\mathrm{ft}^{3} / \mathrm{s}$ in 2005 showed single-line (Type 1) hysteresis characteristics, indicative of unlimited sediment supplies during runoff conditions. However, large peak streamflows at the Indian Creek site did not result in turbidity conditions or sediment loads as large as those that occurred at the other sites under similar streamflow conditions.

\section{Dissolved Solids, Chloride, and Other Major lons}

Dissolved solids in surface water primarily consist of the major ions calcium, magnesium, sodium, potassium, bicarbonate, sulfate, and chloride. These ions originate from the decomposition of soils and rocks (Hem, 1992). In addition, dissolved solids in stream water can increase as a result of sewage, industrial effluents, agricultural runoff, urban runoff, and atmospheric deposition (Maidment, 1993; Wetzel, 2001). The relative amount of different ions in surface water varies depending on the sources. Dissolved solids are used as an indicator for suitability of water for drinking, irrigation, and industrial use (Maidment, 1993).

All of the regression models for dissolved solids and major ions included specific conductance as the only explanatory variable (table 8), which is reasonable because specific conductance is an indirect measure of the ionized substances in water. Uncertainty in the regression models for dissolved solids (which is a measure of all the major ions combined) was minimal, as indicated by high $\mathrm{R}^{2}$ values ranging from 0.88 to 0.98 , and low RMSE values of 0.0523 or less (table 8 ). The ranges of specific conductance and dissolved solids at the Blue River and Kill Creek sites were smaller than the other sites (because of the larger percentage of nonurban land use upstream from the sites) which contributed to more uncertainty in the models. Uncertainty in models for individual ions varied. $\mathrm{R}^{2}$ values ranged from 0.66 for chloride at the Kill Creek site to 0.97 for sodium at the Indian Creek site. RMSE values ranged from 0.0423 for magnesium at the Blue River site to 0.168 for chloride at the Kill Creek site (table 8). A much smaller portion of dissolved solids at nonurban sites comes from chloride compared to urban sites. 


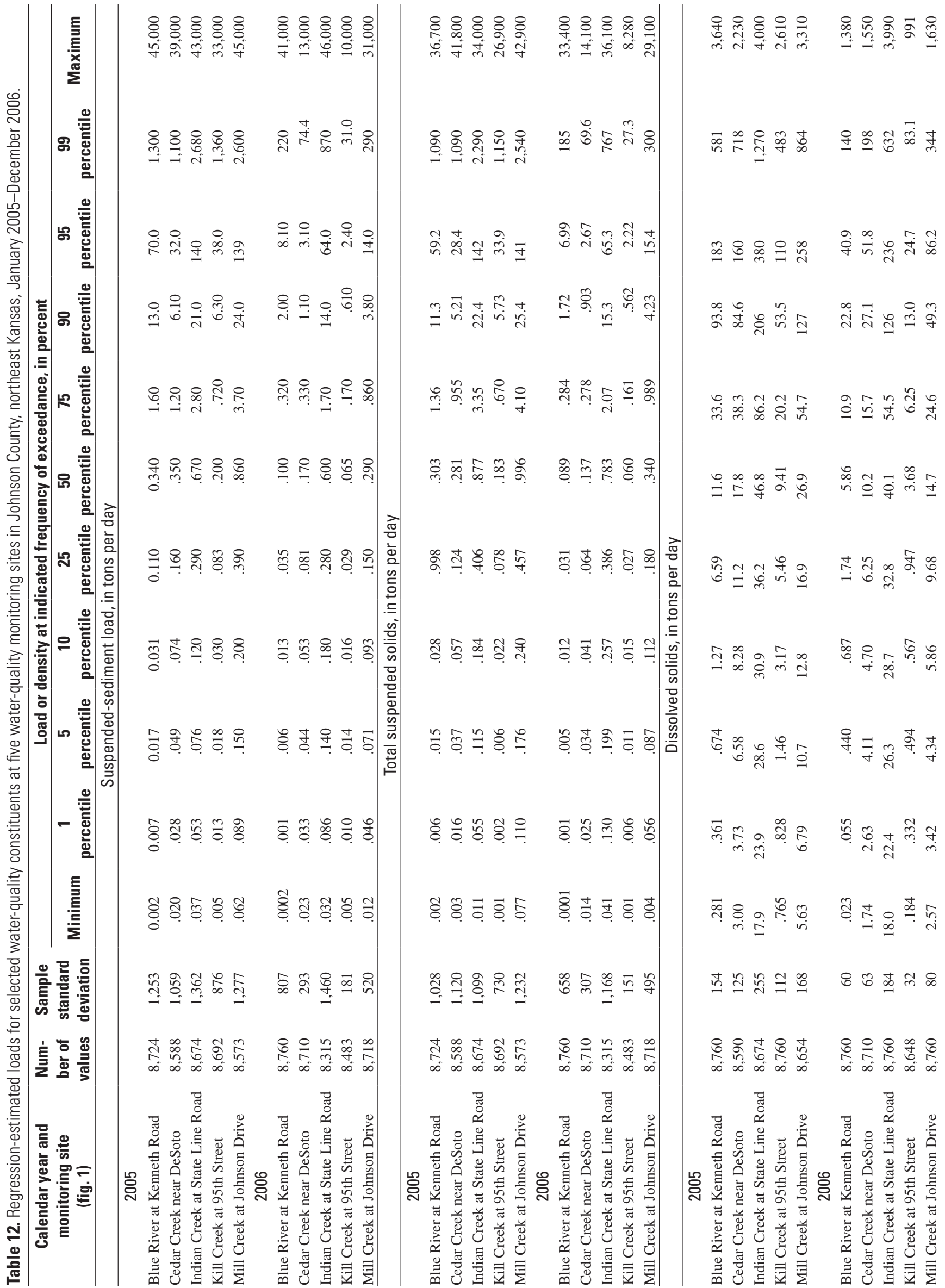




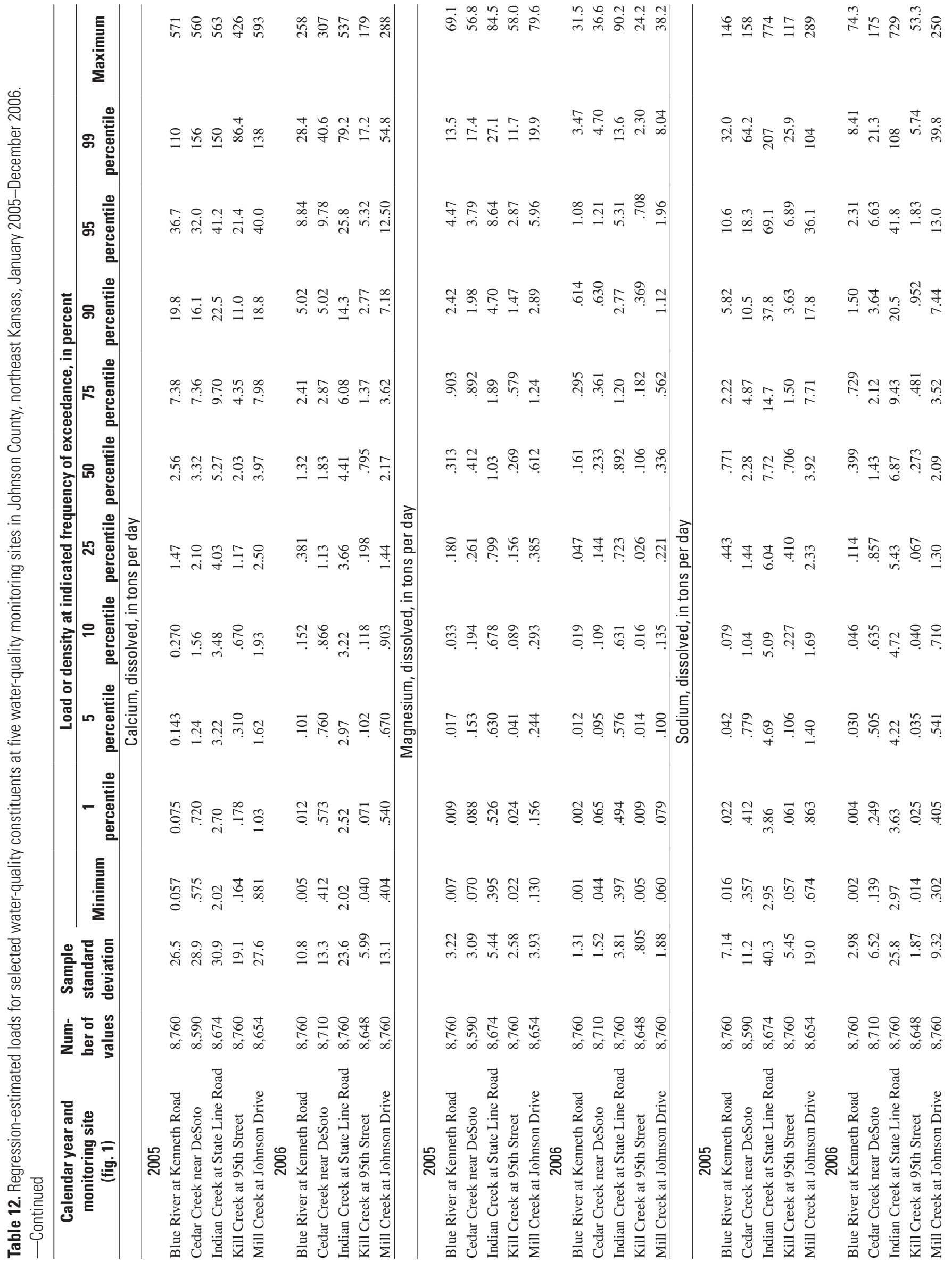




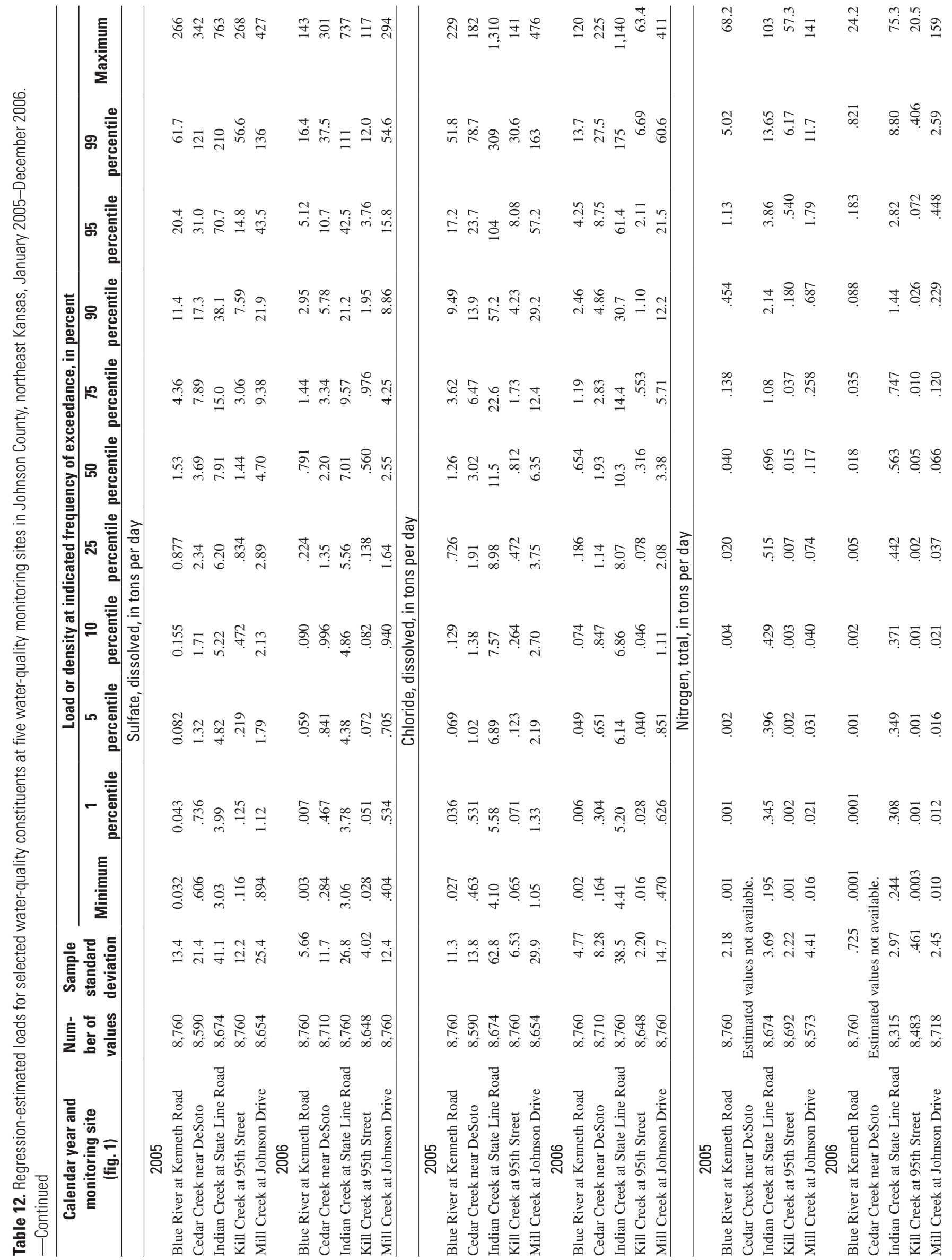




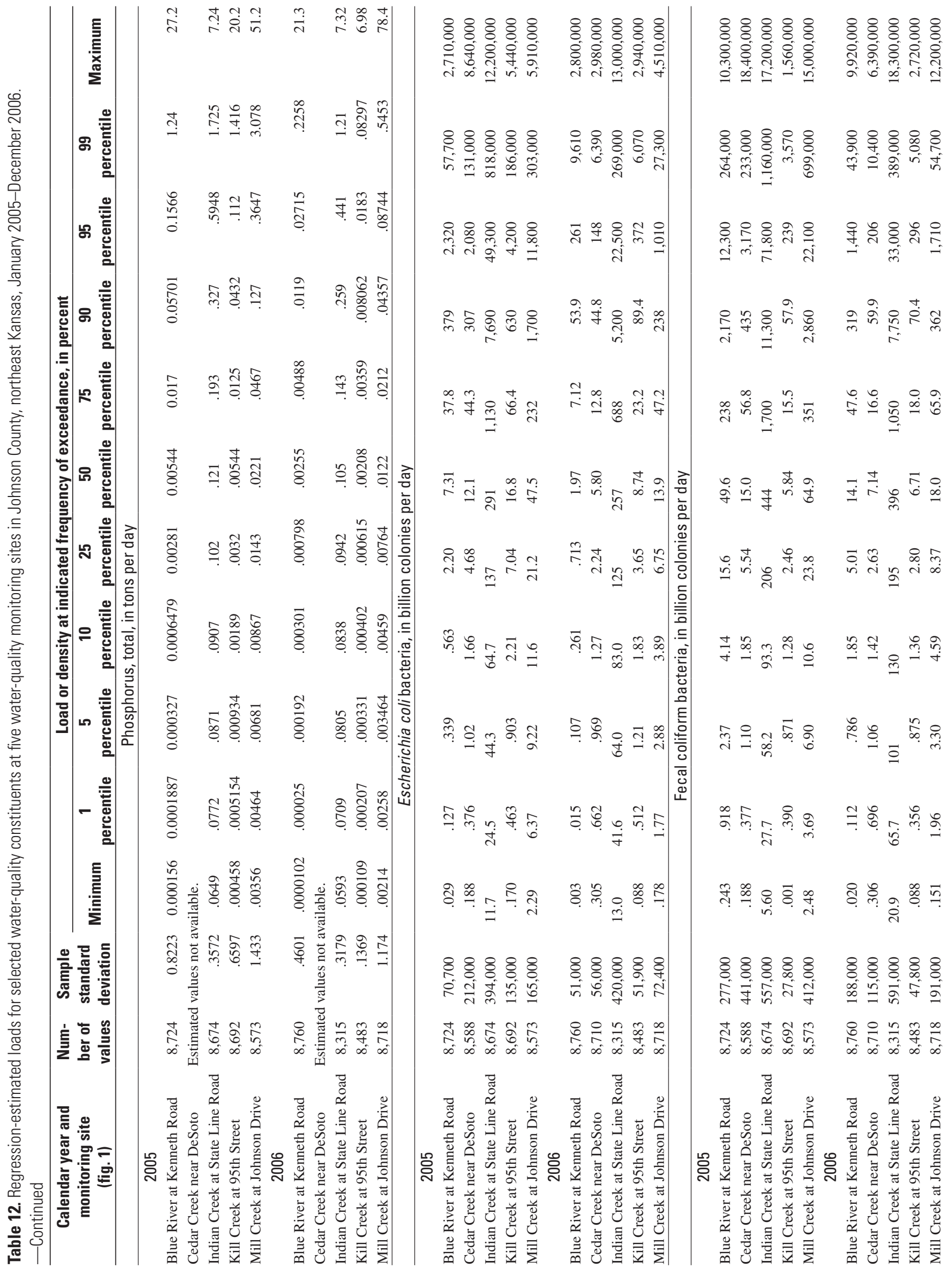




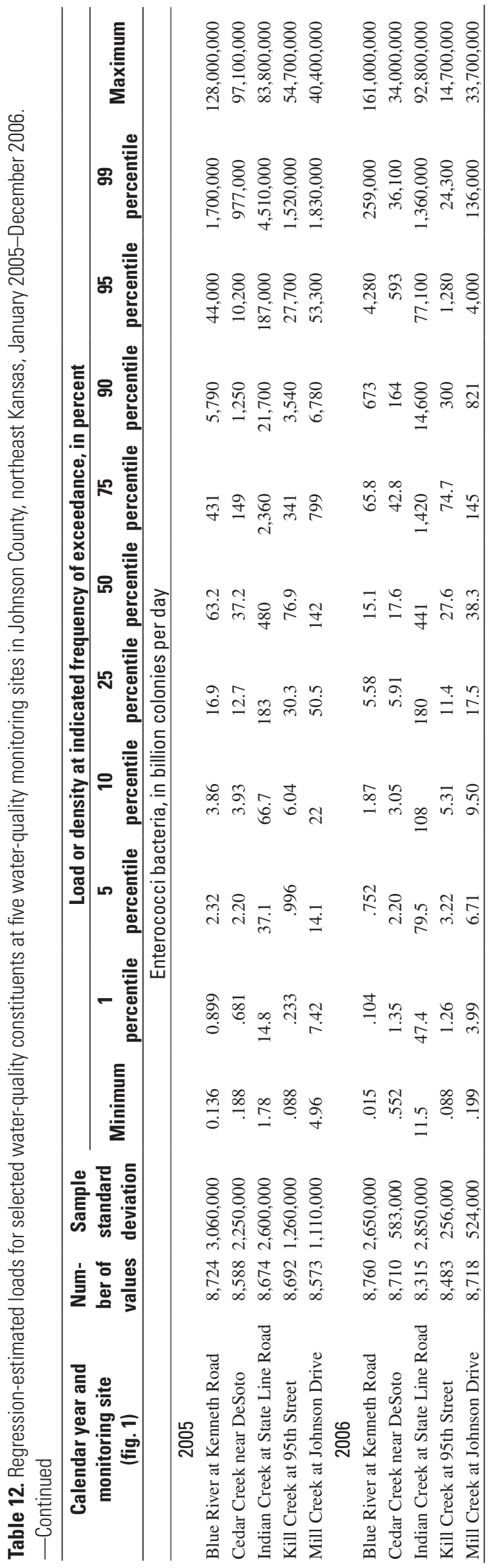




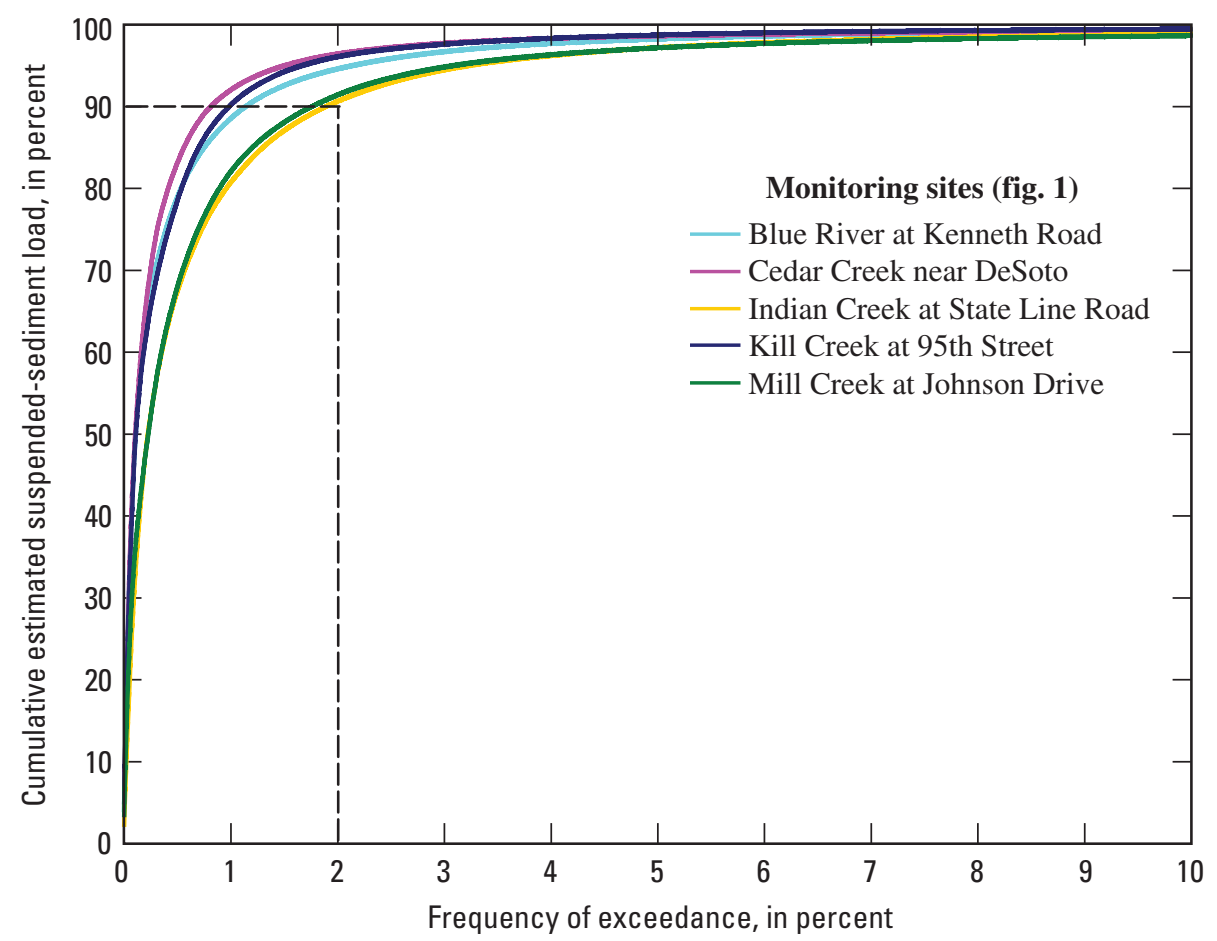

Figure 18. Cumulative estimated suspended-sediment loads and frequency of exceedance at five water-quality monitoring sites in Johnson County, Kansas, January 2005-December 2006.

In the category of dissolved solids and major ions, chloride was selected for additional evaluation and discussion in this report. Chloride, an ion of interest because of the aquatic-life criteria established by KDHE and USEPA, occurs naturally in various rock types. However, it generally occurs in low concentrations and is most likely to occur as an impurity (Hem, 1992). Potential sources include agricultural and industrial runoff, and WWTF discharges. In addition, chloride, in the form of sodium chloride $(\mathrm{NaCl})$, calcium chloride $(\mathrm{CaCl})$, and magnesium chloride $(\mathrm{MgCl})$, is a major component of road de-icers (U.S. Environmental Protection Agency, 2002a). KDHE has established an acute aquatic-life criterion of $860 \mathrm{mg} / \mathrm{L}$ for chloride (Kansas Department of Health and Environment, 2005). The USEPA-recommended chronic freshwater quality criterion for chloride is $230 \mathrm{mg} / \mathrm{L}$ (U.S. Environmental Projection Agency, 2002b). In this report chloride concentrations are compared to the acute aquaticlife criterion of $860 \mathrm{mg} / \mathrm{L}$ and to the Secondary Drinking Water Regulation of $250 \mathrm{mg} / \mathrm{L}$ (U.S. Environmental Protection Agency, 2003a) which also corresponds to the Kansas chloride criterion for domestic water supply at the point of water supply diversion (Kansas Department of Health and Environment, 2005).

Like the other major ions, the regression models for chloride include specific conductance as the only explanatory variable (table 8). Uncertainty in the models is small for the most urban sites (Indian and Mill Creeks). Uncertainty associated with the chloride models for the Blue River and Kill Creek sites is larger in part because the range in chloride concentrations is smaller at these two nonurban sites (table 8). In addition, chloride generally makes up a smaller proportion of dissolved solids at nonurban sites where dissolved solids would be expected to originate from natural sources. Chloride concentrations in discrete samples ranged from $5.0 \mathrm{mg} / \mathrm{L}$ at the Kill Creek site to $1,678 \mathrm{mg} / \mathrm{L}$ at the Indian Creek site (table 8). Two discrete samples, collected in January 2004 and January 2007 at the Indian Creek site and affected by road-salt application, exceeded the KDHE criterion of $860 \mathrm{mg} / \mathrm{L}$. Corresponding specific conductance in the discrete-sample dataset ranged from $160 \mu \mathrm{S} / \mathrm{cm}$ at the Kill Creek site to $5,710 \mu \mathrm{S} / \mathrm{cm}$ at the Indian Creek site.

The slopes of the chloride regression models are similar for the sites with comparable land use (fig. 14B). The slopes for the Blue River and Kill Creek regression models are similar, and the slopes for the Indian and Mill Creek models are similar, indicating similar chloride sources in the watersheds (predominantly agricultural sources in the first two watersheds and urban sources in the latter two watersheds). The steepest regression slope occurred in the Cedar Creek model, indicating larger chloride concentrations than at the other sites as specific conductance increased. The Cedar Creek watershed contains a larger percentage of industrial land use than the other four watersheds (table 1) which may result in varying principal sources of chloride possibly resulting in a different regression relation at this site.

Regression-estimated chloride concentrations were largest at the Indian and Mill Creek sites (fig. 21), the two most urban monitoring sites which also are affected by WWTFs. 
(A) Blue River at Kenneth Road (fig. 1)

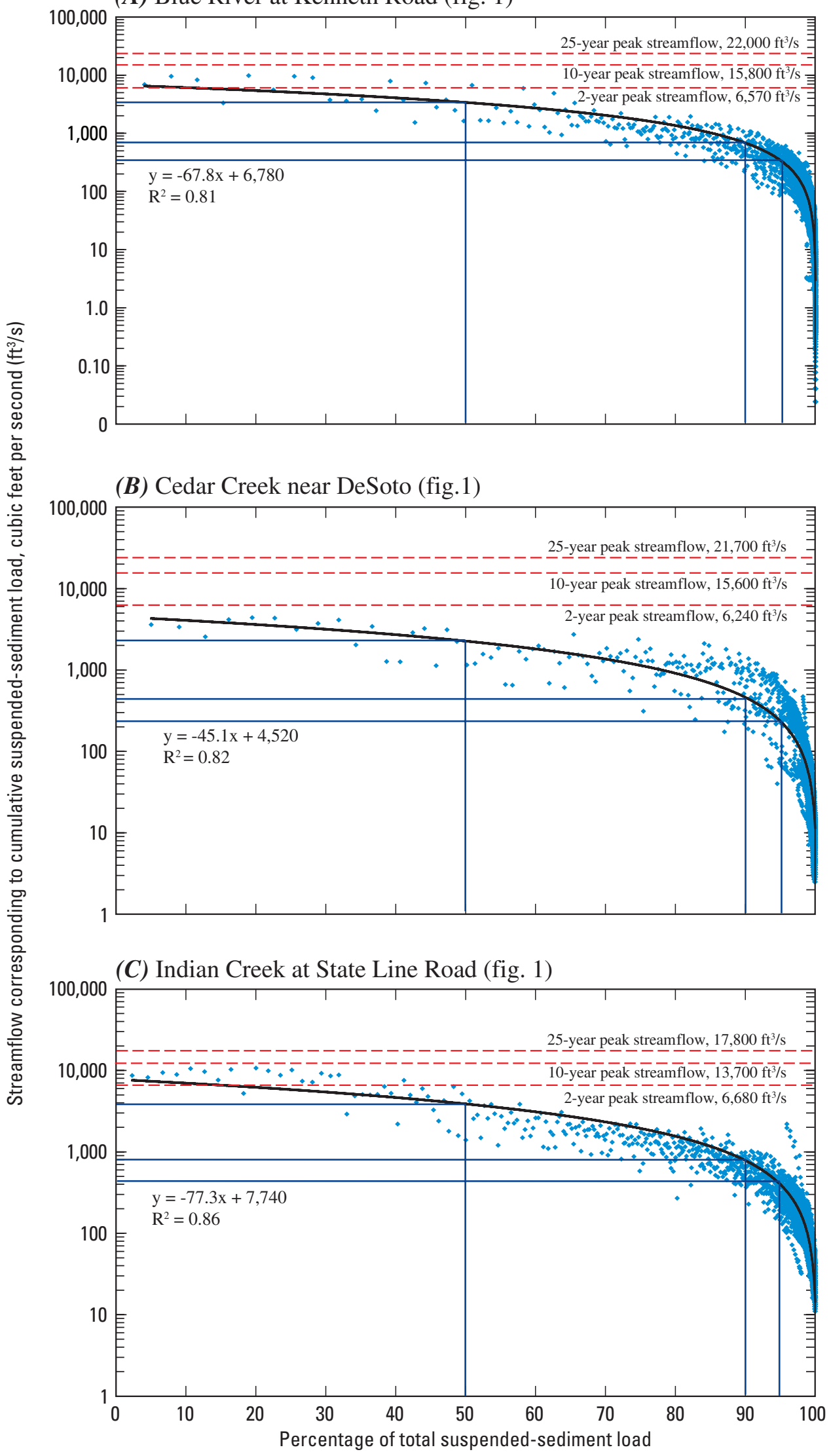

Figure 19. Streamflow and cumulative suspended-sediment load at five water-quality monitoring sites in Johnson County, Kansas, 2005-06. 
(D) Kill Creek at 95th Street (fig.1)

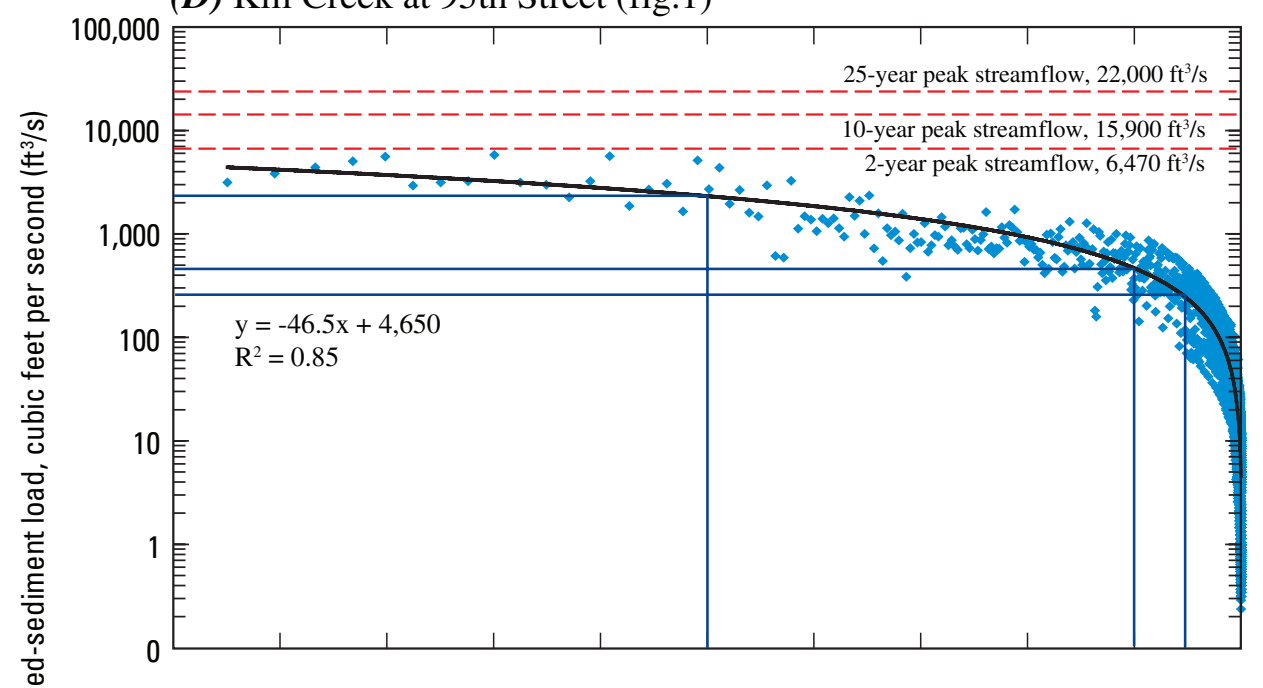

(E) Mill Creek at Johnson Drive (fig.1)

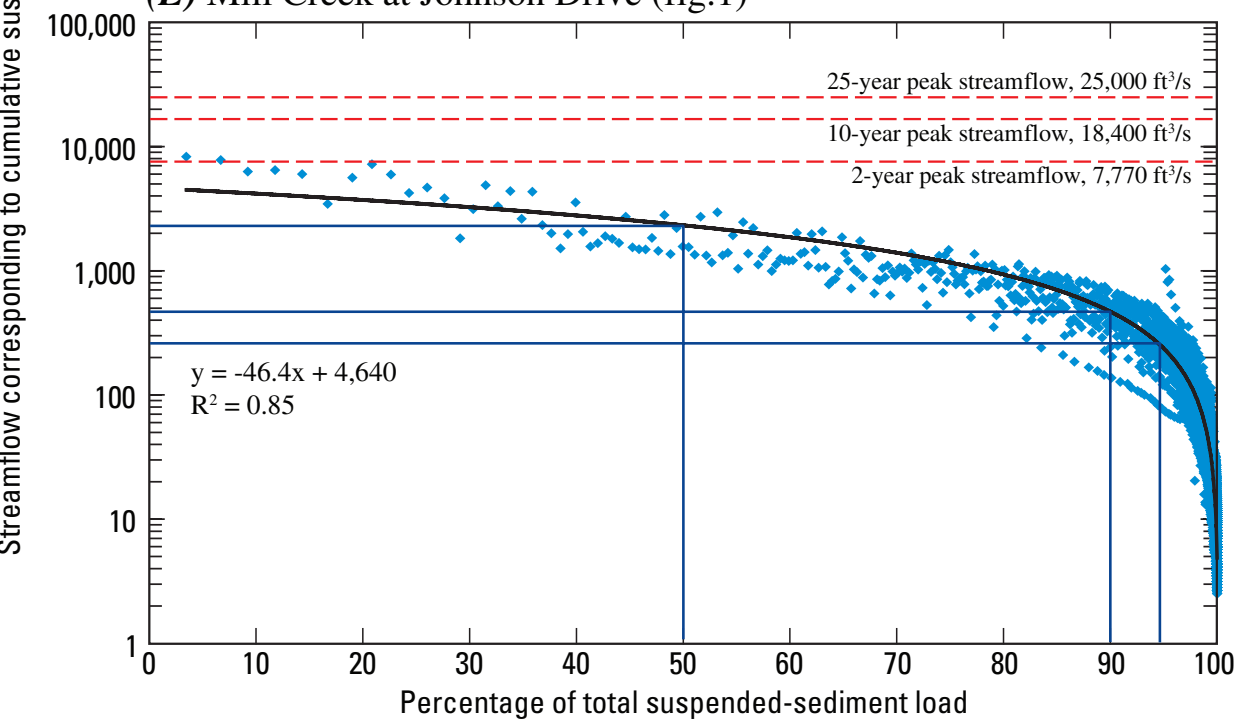

Figure 19. Streamflow and cumulative suspended-sediment load at five water-quality monitoring sites in Johnson County, Kansas, 2005-06.-Continued

Lee and others (2005) reported that during base flow, chloride concentrations in samples at or immediately downstream from WWTFs generally were the largest in each watershed. Estimated chloride concentrations ranged from about $5 \mathrm{mg} / \mathrm{L}$ at the Cedar Creek site in 2006 to $1,500 \mathrm{mg} / \mathrm{L}$ at the Indian Creek site in 2006 (table 10). The median chloride concentration at each site in 2005 was similar to that in 2006, even though the maximum chloride concentration at the Indian and Mill Creek sites in 2006 was nearly double the respective maximums in 2005. Generally, the median chloride concentration from January 2005 through December 2006 at the Indian Creek site was about four times the median at the Kill Creek site (table 10). The steep upward slopes in the duration curves for the Indian and Mill Creek sites are a result of road-salt application during winter months (fig. 21). About 10 percent of the time, the Indian and Mill Creek sites were noticeably affected by increased chloride concentrations as a result of road-salt runoff, while there were no major effects from roadsalt application at the Blue River and Kill Creek monitoring sites (fig. 21). The effect of accumulated road salt on ground water and base flow throughout the remainder of the year is unknown. Studies have shown that road salt can accumulate in soil and groundwater resulting in elevated chloride even when no salt is being applied (Kaushal and others, 2005).

At the Indian Creek site during 2005-06, there was a 50-percent probability of chloride concentration exceeding the 250-mg/L USEPA Secondary Drinking Water Regulation about 8 percent of the time, and exceeding the $860-\mathrm{mg} / \mathrm{L}$ KDHE acute aquatic-life criterion less than 1 percent of the time (fig. 22). Estimated annual chloride load at Indian Creek 


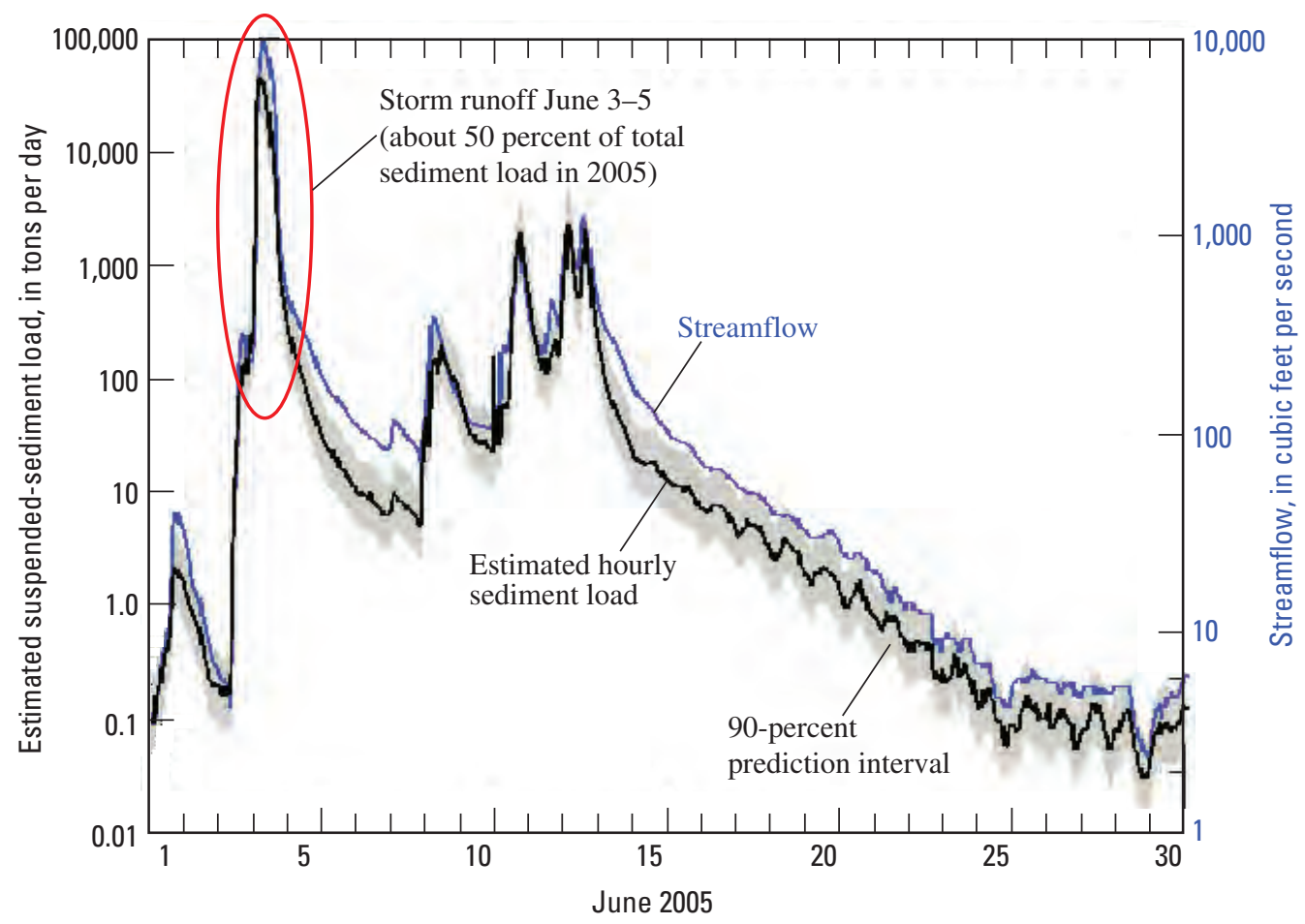

Figure 20. Estimated suspended-sediment load during June 2005 at the Blue River monitoring site, Johnson County, Kansas.

in 2006 was more than twice that of Mill Creek and more than 25 times the estimated annual load at Kill Creek (table 11). About 50 percent of the total chloride load during 2005-06 occurred in less than 10 percent of the time at all five monitoring sites (fig. 23). Estimated yield characteristics were similar to load in that the Indian Creek chloride yield in 2006 was more than double that of Mill Creek, and more than 20 times that of Kill Creek (table 11).

Seasonal differences in chloride concentration and loads occur because of differences in streamflow sources and effects of road-salt application. Winter chloride concentrations (November 1-February 28) generally were larger than other seasons at all monitoring sites in part because ground water is a natural source of chloride and during the winter streamflow originates primarily from ground water with minimal dilution effects from rainfall. At urban sites, very high chloride concentrations during the winter (fig. 24) were caused by application of deicing chemicals to keep roadways clear of snow and ice. Nationwide, the most commonly used and economical deicer is sodium chloride (salt), which is effective because it lowers the freezing point of water, preventing ice and snow from bonding to the pavement and allowing easy removal by snow plows (U.S. Environmental Protection Agency, 2002a). During two winter storms in December 2005, an estimated 2,550 tons of salt, 917 tons of salt/sand mix, and 8,000 gal of calcium chloride were applied to roadways in Overland Park, Kansas, (City of Overland Park, written commun., April 2005) which includes a large part of the Indian
Creek watershed. Deicing chemicals concentrate in runoff and enter surface and ground water, potentially causing problems for aquatic environments. The Indian and Mill Creek sites were most affected by road-salt application, and the maximum concentrations were larger during 2006 (table 11) when annual precipitation and streamflow were less than normal compared to 2005. In 2005, 39 percent (Kill Creek) to 57 percent (Indian Creek) of the total annual chloride load occurred during the winter (November 1 through February 28); in 2006, 23 percent (Kill Creek) to 46 percent (Indian Creek) of the total annual load occurred during the winter (table 11).

Two apparently similar chloride runoff occurrences resulting from road-salt application can nevertheless have different effects on stream chemistry, depending on rainfall, snowmelt, and runoff. Cedar, Indian, and Mill Creeks were affected by road-salt runoff in January and February 2005 (fig. 25). During that time at Indian Creek, for example, the first chloride increase, caused primarily by warming temperatures and gradual runoff from snowmelt, resulted in a 10-day period when chloride concentrations were larger than $250 \mathrm{mg} / \mathrm{L}$, and total chloride load during that period was 725 tons. The second chloride increase resulted in about 6 days when chloride concentration was larger than $250 \mathrm{mg} / \mathrm{L}$, but the chloride load was nearly double the load during the first chloride increase at 1,330 tons because of the larger associated streamflow. These two periods of runoff contributed 19 percent of the total chloride load in Indian Creek in 2005. 
Table 13. Percentage of annual suspended-sediment load that occurred during the single largest storm runoff for 2005 at five waterquality monitoring sites in Johnson County, northeast Kansas.

\begin{tabular}{|c|c|c|c|}
\hline $\begin{array}{l}\text { Continuous } \\
\text { in-stream } \\
\text { monitoring site } \\
\text { (fig. 1) }\end{array}$ & $\begin{array}{c}\text { Dates of } \\
\text { largest storm } \\
\text { runoff in } 2005\end{array}$ & $\begin{array}{l}\text { Peak stream- } \\
\text { flow, in } \\
\text { cubic feet per } \\
\text { second }\end{array}$ & $\begin{array}{l}\text { Percentage } \\
\text { of annual } \\
\text { suspended- } \\
\text { sediment load }\end{array}$ \\
\hline $\begin{array}{l}\text { Blue River at } \\
\text { Kenneth } \\
\text { Road }\end{array}$ & June $3-5$ & 9,840 & 52 \\
\hline $\begin{array}{l}\text { Cedar Creek } \\
\text { near DeSoto }\end{array}$ & June $3-6$ & 4,390 & 41 \\
\hline $\begin{array}{l}\text { Indian Creek } \\
\text { at State Line } \\
\text { Road }\end{array}$ & June $3-5$ & 10,500 & 31 \\
\hline $\begin{array}{l}\text { Kill Creek at } \\
\text { 95th Street }\end{array}$ & June 3-6 & 5,820 & 42 \\
\hline $\begin{array}{l}\text { Mill Creek } \\
\text { at Johnson } \\
\text { Drive }\end{array}$ & August 19-22 & 8,280 & 20 \\
\hline
\end{tabular}

\section{Fecal-Indicator Bacteria}

Fecal coliform, E. coli, and enterococci are the three most common types of bacteria used as indicators of pathogens in surface water. Indicator bacteria are used to evaluate the sanitary quality of water and its use as a public water supply and for recreational activities such as swimming, wading, boating, and fishing (American Public Health Association and others, 1995). The presence of $E$. coli indicates the possible presence of pathogens found in feces of warmblooded animals (Dufour, 1977). These indicator bacteria and pathogens may cause human diseases ranging from mild diarrhea to respiratory disease, septicemia, meningitis, and polio (Dufour, 1977).

Kansas water-quality criteria for $E$. coli bacteria require stream sites to be classified and regulated according to designated use and accessibility. Most segments of the Blue River and Cedar and Mill Creeks have been designated as Class C, indicating primary contact recreation not open to and accessible by the public. Most segments of Kill Creek are Class B, indicating primary contact recreation accessible by the public with landowner permission. Designated uses for Indian Creek have not been determined by the State (Kansas Department of Health and Environment, 2005). Primary contact recreational use criteria for $E$. coli state that for the three use classifications of water (Appendix 1), a geometric mean of five samples collected during separate 24-hour periods within a 30-day period cannot exceed 160, 262, and 427 colony-forming units per $100 \mathrm{~mL}$ of water from April through October each year. From November through March primary contact criteria for E. coli are 2,358 or $3,843 \mathrm{col} / 100 \mathrm{~mL}$ for the three use classes (Kansas Department of Health and Environment, 2005). Geometric means were not applied in this report because the data used are continuous rather than five discrete samples collected during separate 24-hour periods within 30-day periods, as described by the criteria. A direct comparison to the actual criteria values, however, is considered meaningful when evaluating continuous data.

All regression models for indicator bacteria included turbidity as the only explanatory variable (table 8). Indicator bacteria have been shown to be closely related to sediment because bacteria attach to sediment particles and because sediment concentration is closely related to turbidity (Rasmussen and Ziegler, 2003; Rasmussen and others, 2005). $\mathrm{R}^{2}$ values ranged from 0.67 for fecal coliform at the Indian Creek site to 0.90 at the Cedar Creek site for enterococci, and RMSE values ranged from 0.445 for E. coli at the Cedar Creek site to 0.668 for enterococci at the Mill Creek site (table 8). Some regression models for indicator bacteria are characterized by somewhat high variability in data (table 8) and in the relation between bacteria and sediment (table 9).

E. coli bacteria models for each site are shown in figure $14 C$. The models were developed using discrete samples ranging from less than 10 to greater than $20,000 \mathrm{col} / 100$ $\mathrm{mL}$ at each site and turbidity values ranging from less than 10 to greater than 900 FNUs (table 8). The relation between turbidity and E. coli bacteria at the Indian Creek site is different from the other sites (fig. 14C). The slope is less and the $\mathrm{y}$-intercept is larger, indicating that at small turbidity values, E. coli densities at the Indian Creek site are larger relative to the other sites. The Indian Creek site is located in the most urban watershed. Lee and others (2005) found larger indicator bacteria densities at stream sites in urban areas (upstream from WWTFs) than in nonurban areas. Urban sources, such as leaking sewage lines, pet waste, or regrowth in sediment, also may cause larger bacteria densities. In addition, the Indian Creek site is immediately downstream from a WWTF, which likely is affecting indicator bacteria densities. The small indicator bacteria densities found in the WWTF discharge may be enough to affect indicator bacteria densities at the Indian Creek monitoring site during low streamflow conditions. Lee and others (2005) found that resuspension of streambed sediment accounted for less than 1 percent of the bacteria density in stormflow samples.

$E$. coli density at the Indian Creek site was usually the largest of the five monitoring sites (fig. 26) with a median density more than double that of any other site, and at least 15 times the density at the Blue River site (table 10). At the Indian Creek site, the primary criterion $(262 \mathrm{col} / 100 \mathrm{~mL})$ was exceeded about 65 percent of the time, and the secondary criterion $(2,358 \mathrm{col} / 100 \mathrm{~mL})$ was exceeded about 10 percent of the time (fig. 26). The primary contact criterion was exceeded between about 8 and 25 percent of the time at the other monitoring sites. The secondary contact criterion was exceeded less than 5 percent of the time at the other sites. The Blue River and Cedar Creek sites had the smallest bacteria densities most of the time (fig. 26). In 2005-06, estimated densities at Indian Creek generally were largest during the winter, except during the 0-20 percent exceedance period (fig. 27A) compared to the other sites, which experienced the smallest concentrations 


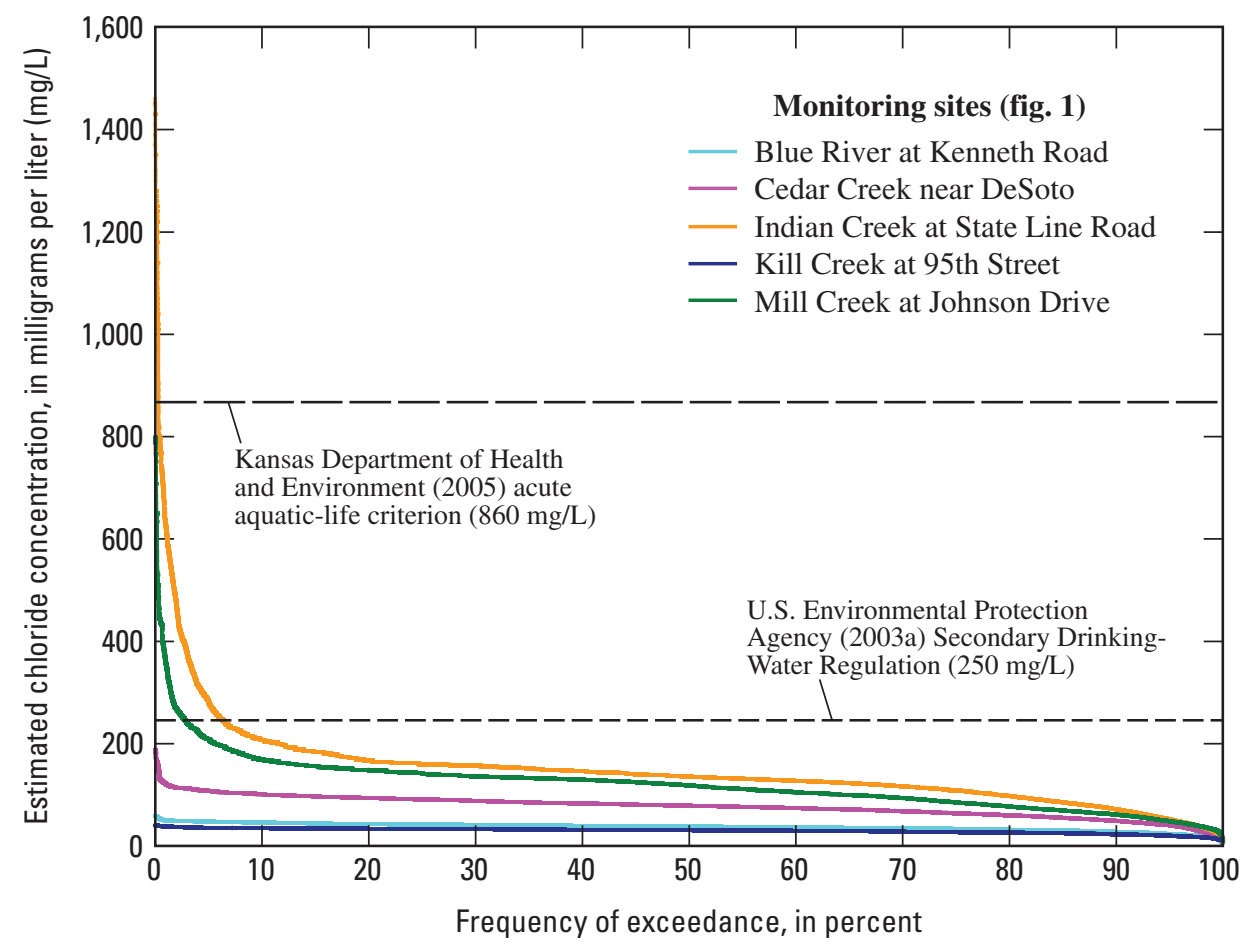

Figure 21. Duration curves for estimated chloride concentration at five water-quality monitoring sites in Johnson County, Kansas, March 2004-December 2006.

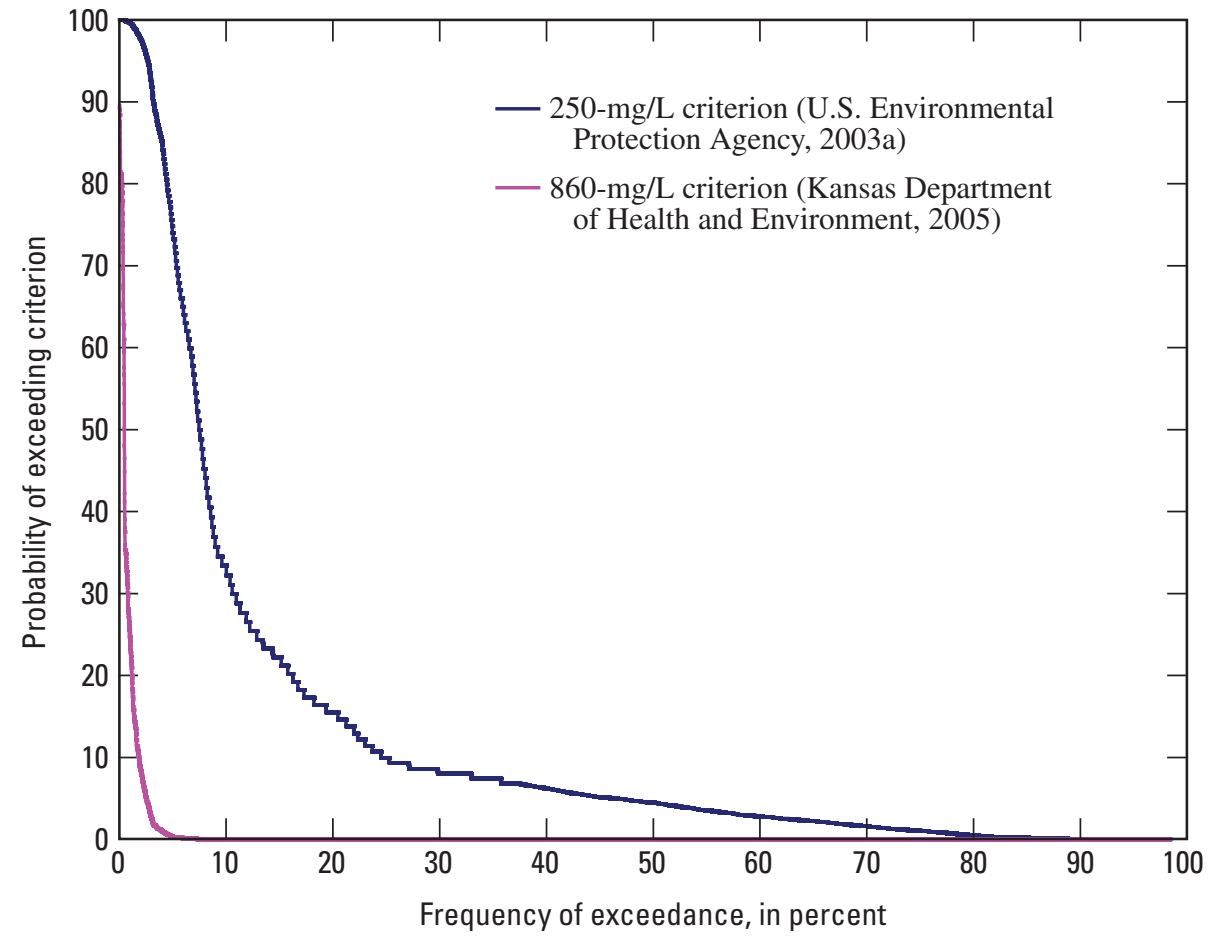

Figure 22. Frequency and probability of exceeding chloride criteria at the Indian Creek monitoring site, Johnson County, Kansas, January 2005-December 2006. 


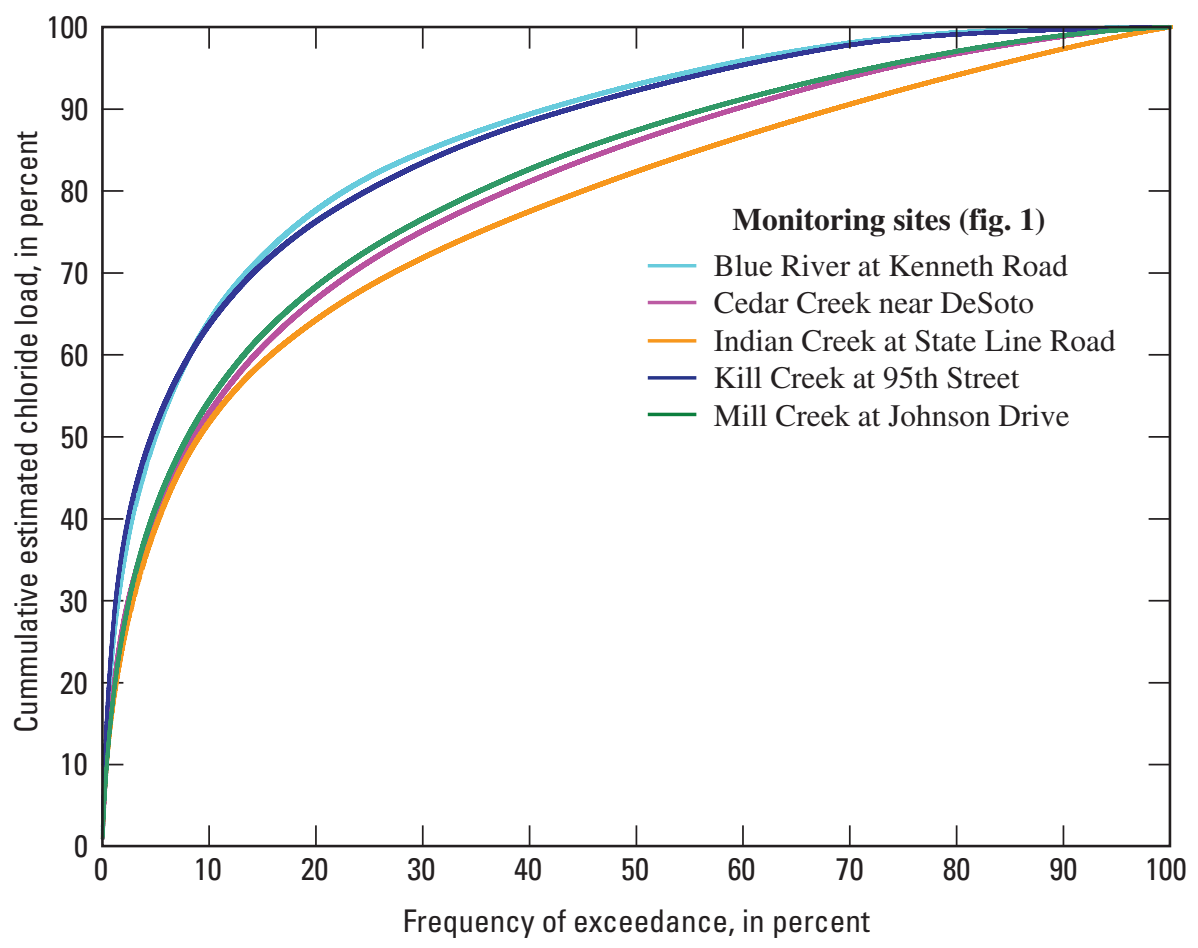

Figure 23. Cumulative estimated chloride loads and frequency of exceedance at five water-quality monitoring sites in Johnson County, Kansas, 2005-06.

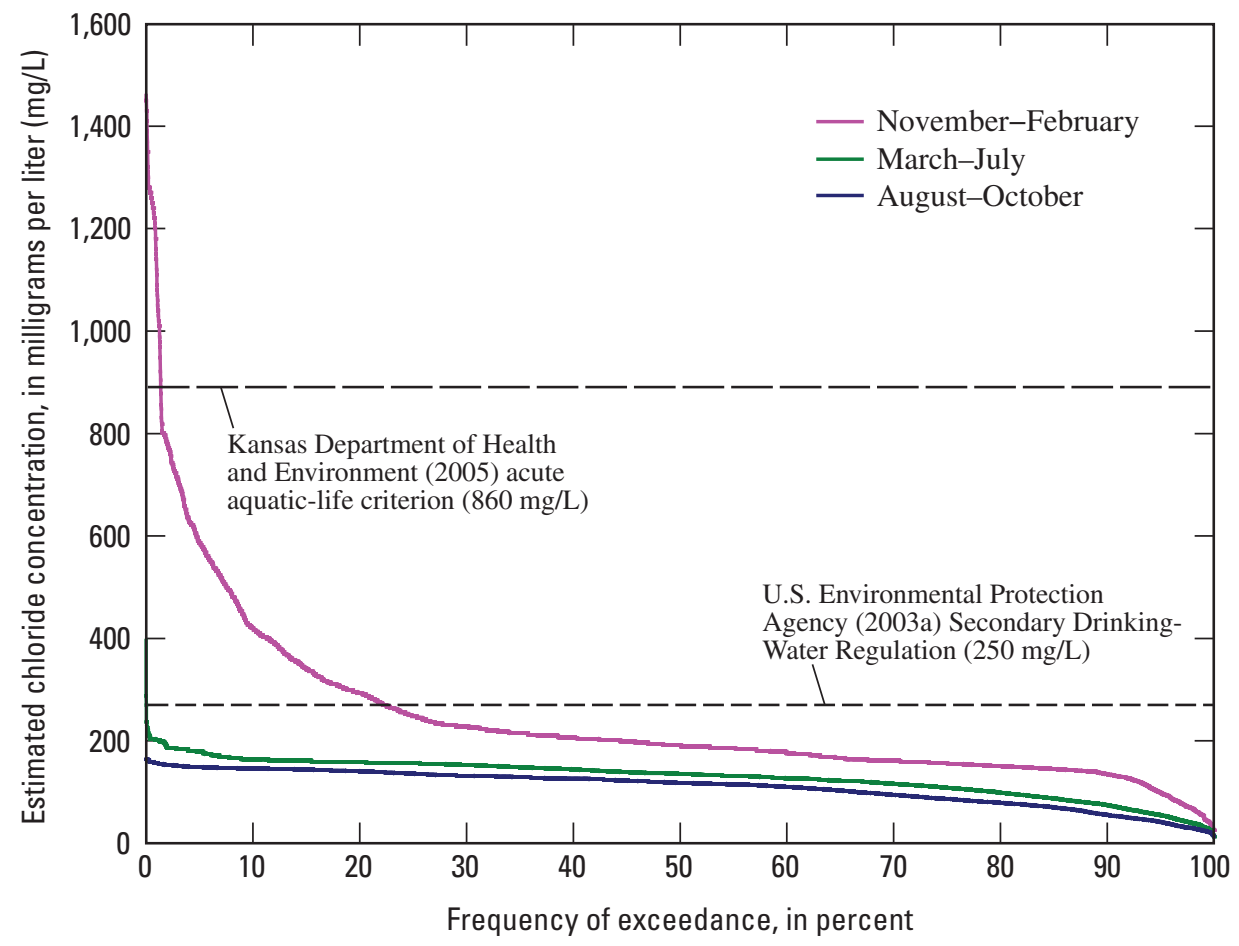

Figure 24. Seasonal chloride concentration duration curves at the Indian Creek monitoring site, Johnson County, Kansas, January 2005-December 2006. 


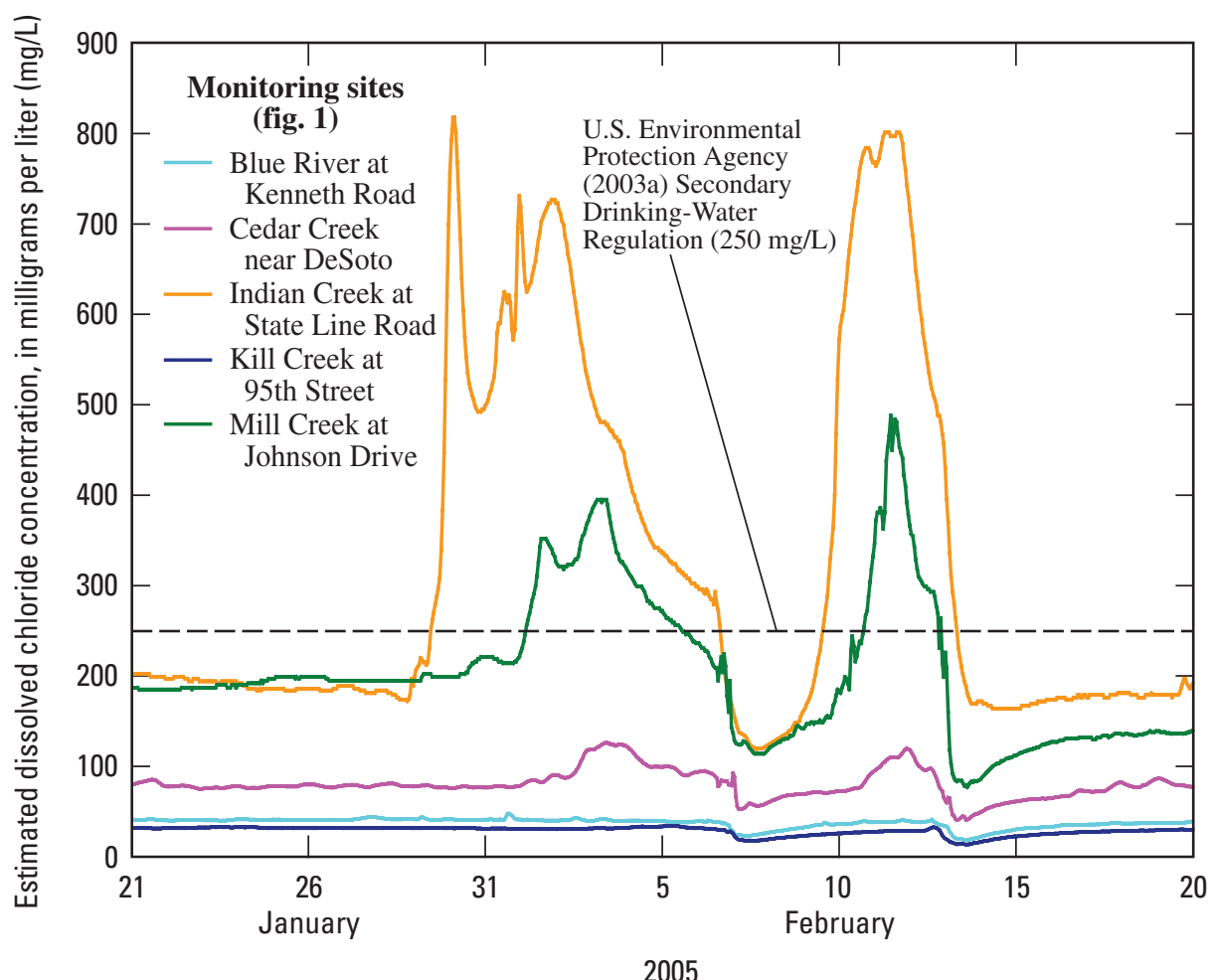

Figure 25. Elevated chloride concentrations during snowmelt as a result of road-salt application at five water-quality monitoring sites in Johnson County, Kansas, January-February 2005.

during the winter (Cedar, for example, in figure 27B). In 2005-06 at the Blue River site during April through October when water-quality criteria apply, there was a 50-percent probability of exceeding the primary criterion about 8 percent of the time and exceeding the secondary criterion 1 percent of the time (fig. 28A). At the Indian Creek site, there was a 50-percent probability of exceeding the primary criterion about 30 percent of the time and exceeding the secondary criterion 10 percent of the time (fig. 29B).

During 2005-06, the largest annual E. coli bacteria loads occurred at the Indian Creek site where the loads were at least double that of any other site (table 11). Also during 2005-06, more than 90 percent of the total E. coli bacteria load at the Cedar Creek site occurred in less than 1 percent of the time, generally during storm runoff, compared to the Indian Creek site where about 80 percent of the total E. coli load occurred less than 1 percent of the time (fig. 29). The largest annual bacteria yields occurred at the Indian Creek site as well (table 11). Potential urban sources of bacteria in Indian Creek include leaking sewer lines, pet waste, wildlife, WWTF discharges and bypasses, and unauthorized dumping. Total annual E. coli loads at the Cedar monitoring site, which is located in the downstream part of the watershed, in 2005 (4,690,000 billion colonies) and 2006 (820,000 billion colonies) bracketed the total annual $E$. coli loads in the upstream parts of the watershed reported by Mau and others (2004), in 2001 (3,900,000 billion colonies) and 2002 (1,400,000 billion colonies). Potential nonurban sources of bacteria in less urban watersheds include livestock, leaking septic systems, and wildlife waste. Permitted confined animal facilities located in the upstream part of the Blue River watershed have a combined animal count of about 1,500 animals, in the upstream part of Cedar and Kill Creeks, 250 and 950 animals, respectively, and in the downstream part of Mill Creek about 100 animals (Eileen Hack, Johnson County Stormwater Management Program, written commun., 2004).

E. coli bacteria densities at all sites increased by several orders of magnitude during storm runoff, indicating that bacteria in Johnson County streams originates primarily from nonpoint sources. This finding is consistent with results of previous studies. Lee and others (2005) reported that E. coli densities and loads were significantly larger (two to four orders of magnitude) in stormflow samples than base-flow samples. Wilkison and others (2006) found that bacteria densities in the Blue River Basin increased by several orders of magnitude during storms because most of the bacteria originated from nonpoint sources.

In addition, when fecal coliform bacteria load from the Blue River WWTF (calculated from data provided by D. Nolkemper, Johnson County Wastewater, written commun., September 2007), which discharges just downstream from the Blue River monitoring site, was added to the total load at the Blue River monitoring site (table 11), less than 1 percent of the total downstream Blue River fecal coliform bacteria load 


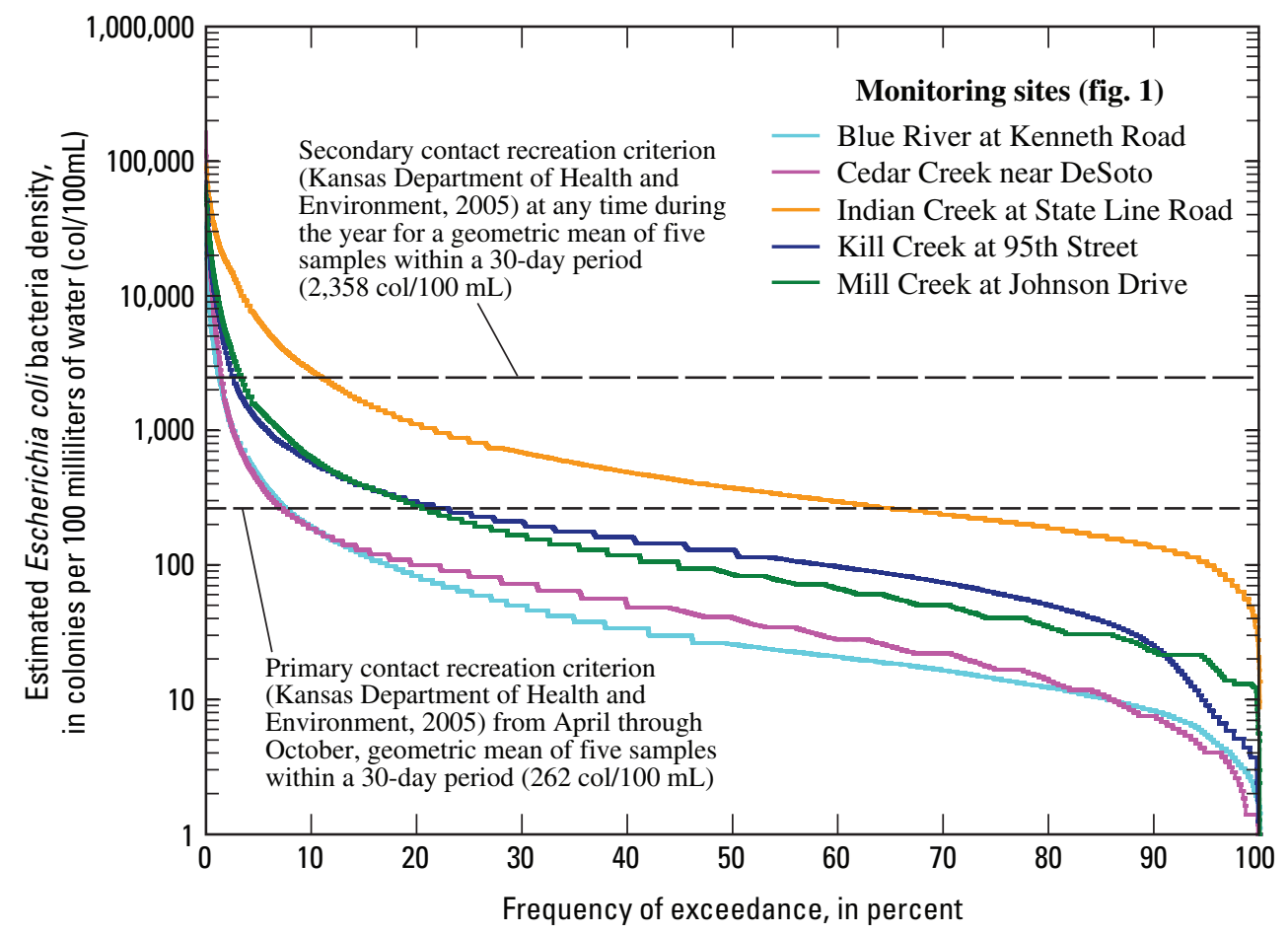

Figure 26. Duration curves for estimated Escherichia coli (E. coli) bacteria density at five water-quality monitoring sites in Johnson County, Kansas, March 2004-December 2006.

originated from the WWTF (fig. 30). The 2005 and 2006 load calculations for fecal coliform bacteria from the two WWTFs on Indian Creek indicated that less than 3 percent of the total fecal coliform bacteria load at the Indian Creek monitoring site originated from WWTFs and more than 97 percent of the load originated from nonpoint sources (fig. 30).

\section{Results of Selected Discrete-Sample Analysis}

All samples collected during this study were analyzed for nutrients and pesticides, and an attempt was made to develop regression models for them. However, because significant explanatory variables were not found for nutrients at all sites and because of large variability in some of the existing models, discrete data, rather than continuous data, are used in this report for making comparisons between the five watersheds.

\section{Nutrients}

Nutrients, including various forms of nitrogen and phosphorus, are essential for proper plant and animal growth but in excess can lead to eutrophication, algal blooms, fish kills, low dissolved oxygen, taste and odor problems, and other disruptions in aquatic ecosystems. Runoff from both urban and nonurban sources contributes to nutrient concentra- tions in streams. Typical nutrient sources include municipal wastewater discharge, fertilizers, and runoff from livestock operations (Masters, 1991). In addition, natural background concentrations of total nitrogen and total phosphorus in headwater streams within the study area have been estimated to be 0.15 to $0.30 \mathrm{mg} / \mathrm{L}$ and $0.06 \mathrm{mg} / \mathrm{L}$ or greater, respectively (Smith and others, 2003). Kansas has no numerical waterquality criteria for total nitrogen or total phosphorus but has set a goal of reducing export of these nutrients from the State by 30 percent (Kansas Department of Health and Environment, 2004b). USEPA Ecoregion IX, Level III subecoregion 40 (Central Irregular Plains which includes Johnson County) recommended criteria are $0.855 \mathrm{mg} / \mathrm{L}$ total nitrogen and $0.0925 \mathrm{mg} / \mathrm{L}$ for total phosphorus (U.S. Environmental Protection Agency, 2003b).

Regression models for nutrient species were developed when significant continuous explanatory variables were found (table 8). Generally, variability in total nutrient models was minimal at the two nonurban sites (Blue River and Kill Creek) compared to the sites where nutrient sources were more diverse (Mill and Indian Creeks). No significant explanatory variables were found for total nitrogen or total phosphorus at the Cedar Creek site. Because watershed comparisons are incomplete without including all sites, discussion of estimated nutrient values in this report is limited. However, duration estimates for estimated concentrations and loads are provided in tables 10 and 12 and continuous estimated data are available on the World Wide Web at http://ks.water.usgs.gov. 
(A) Indian Creek monitoring site (06893390, fig. 1)

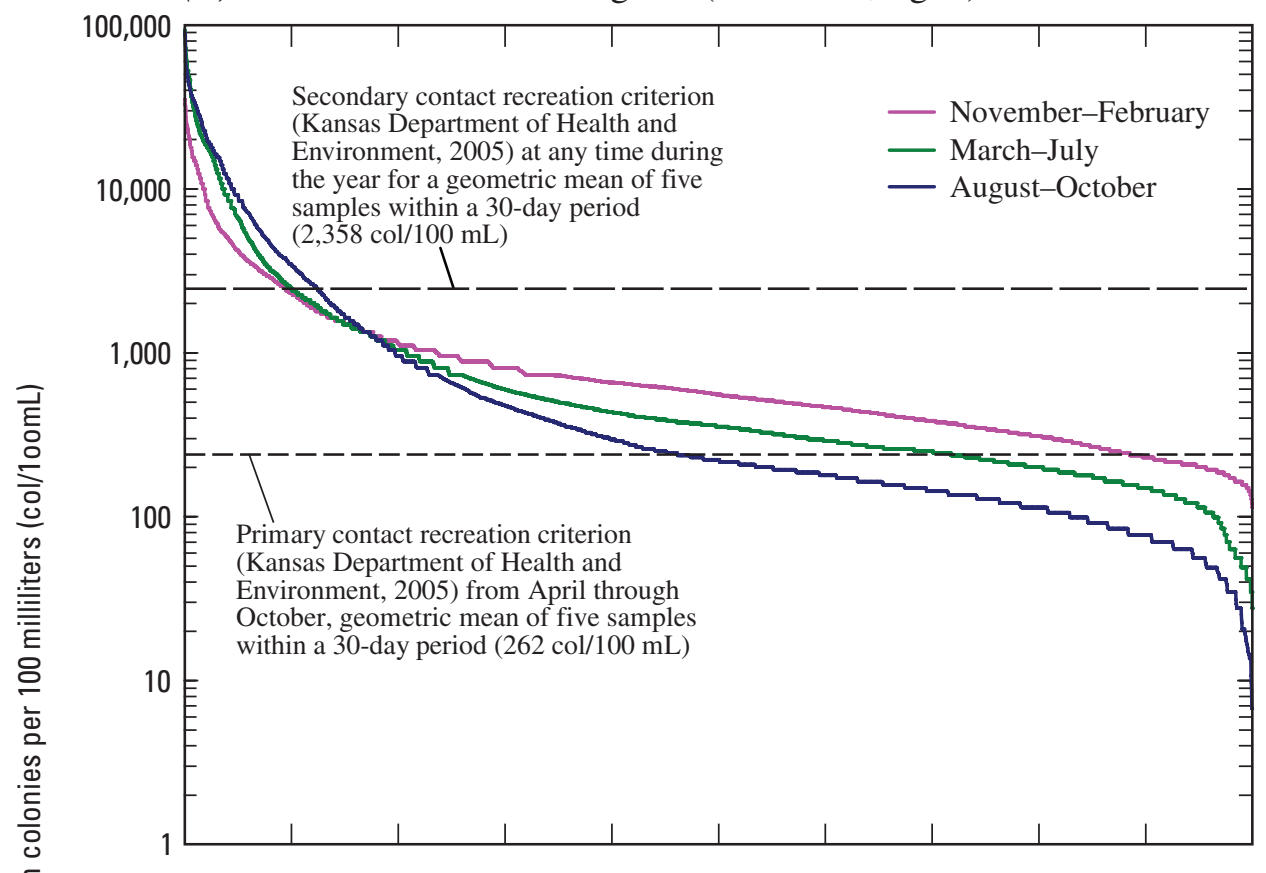

(B) Cedar Creek monitoring site (06892495, fig. 1)

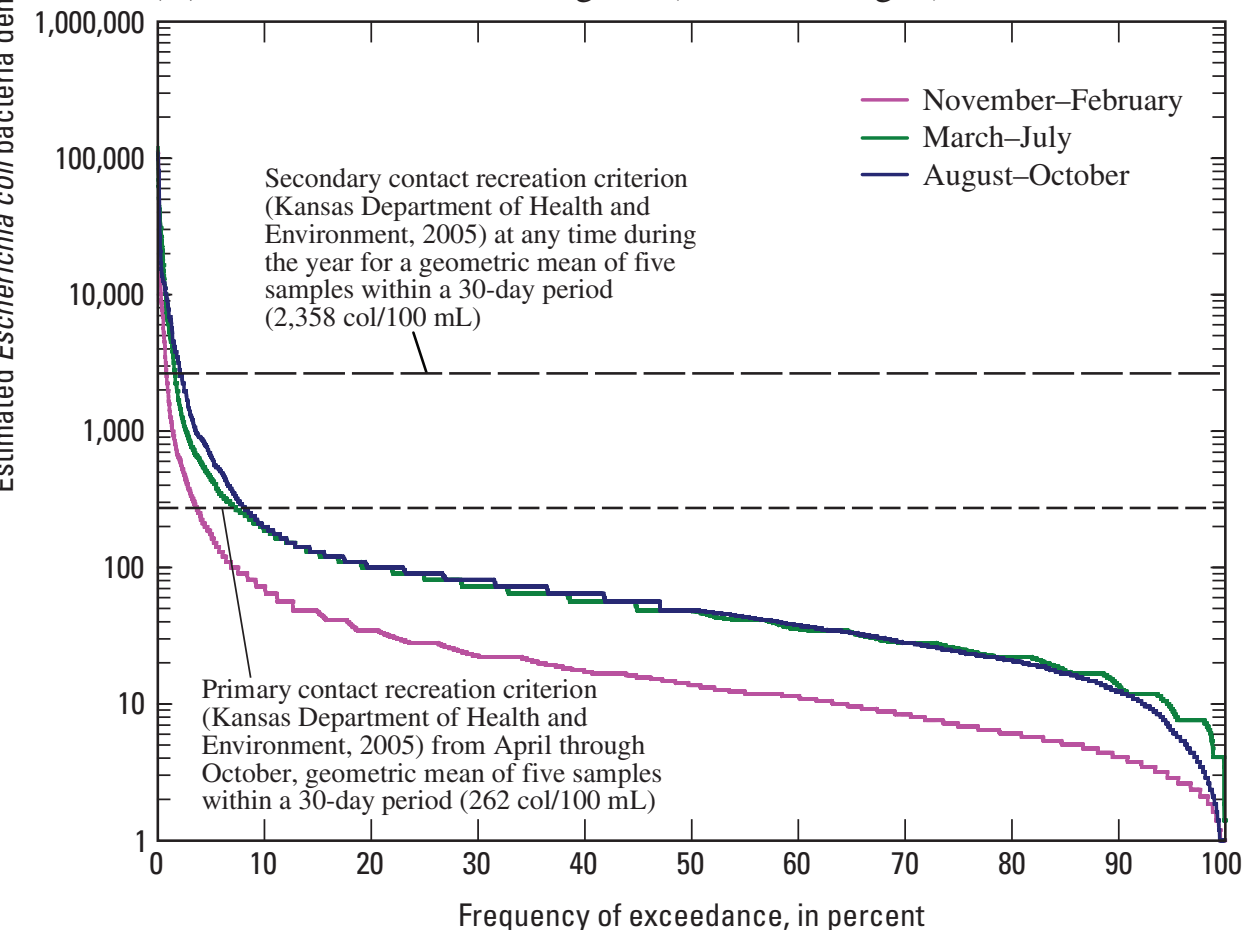

Figure 27. Seasonal duration curves for estimated Escherichia coli (E. coli) bacteria density at the (A) Indian Creek and (B) Cedar Creek water-quality monitoring sites, January 2005-December 2006. 
(A) Blue River monitoring site (06893100, fig.1)

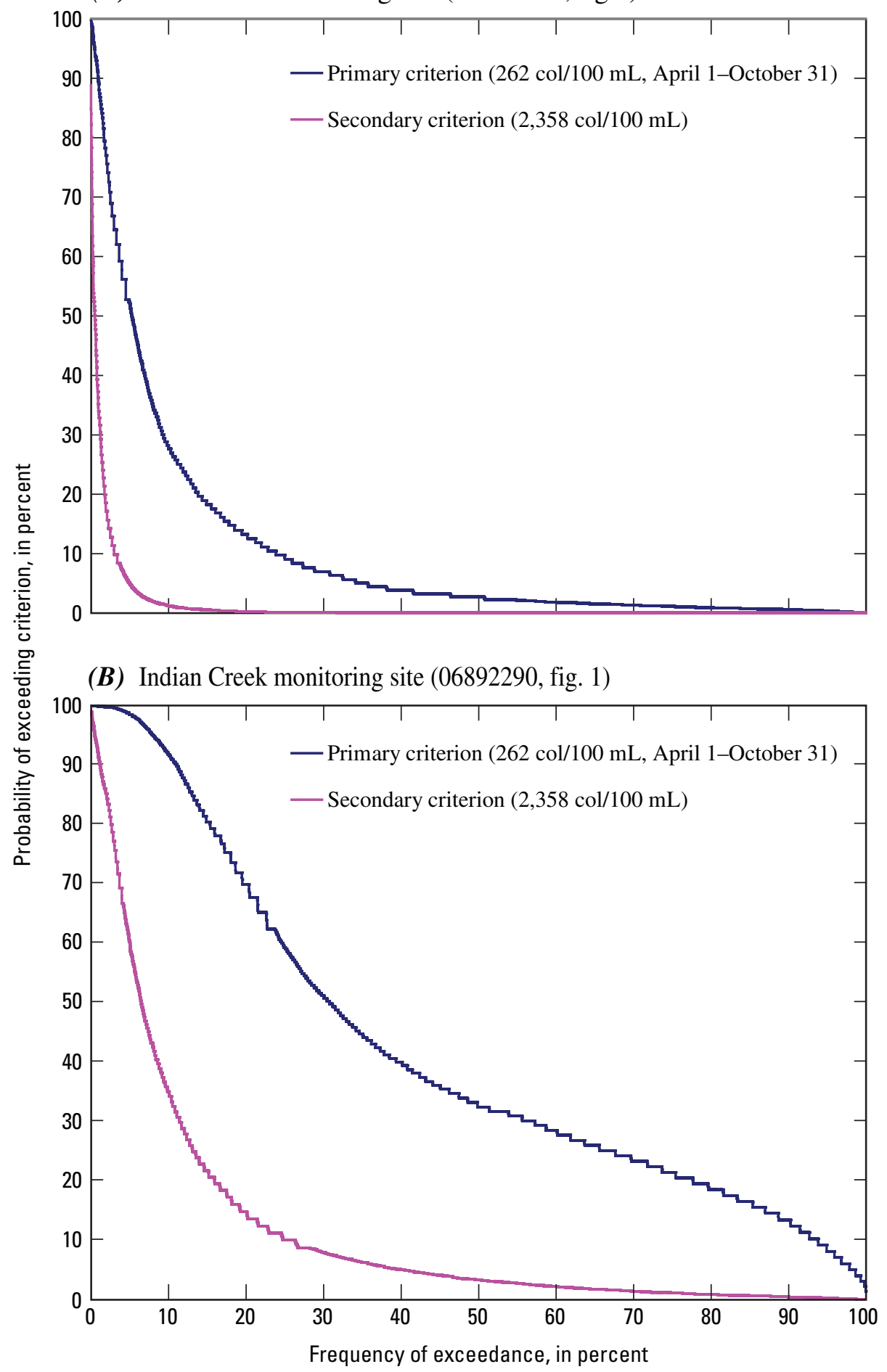

Figure 28. Probability of exceeding Escherichia coli bacteria criteria at the (A)Blue River and (B) Indian Creek water-quality monitoring sites, in Johnson County, Kansas, January 2005December 2006. Recreation criteria from Kansas Department of Health and Environment (2005). 


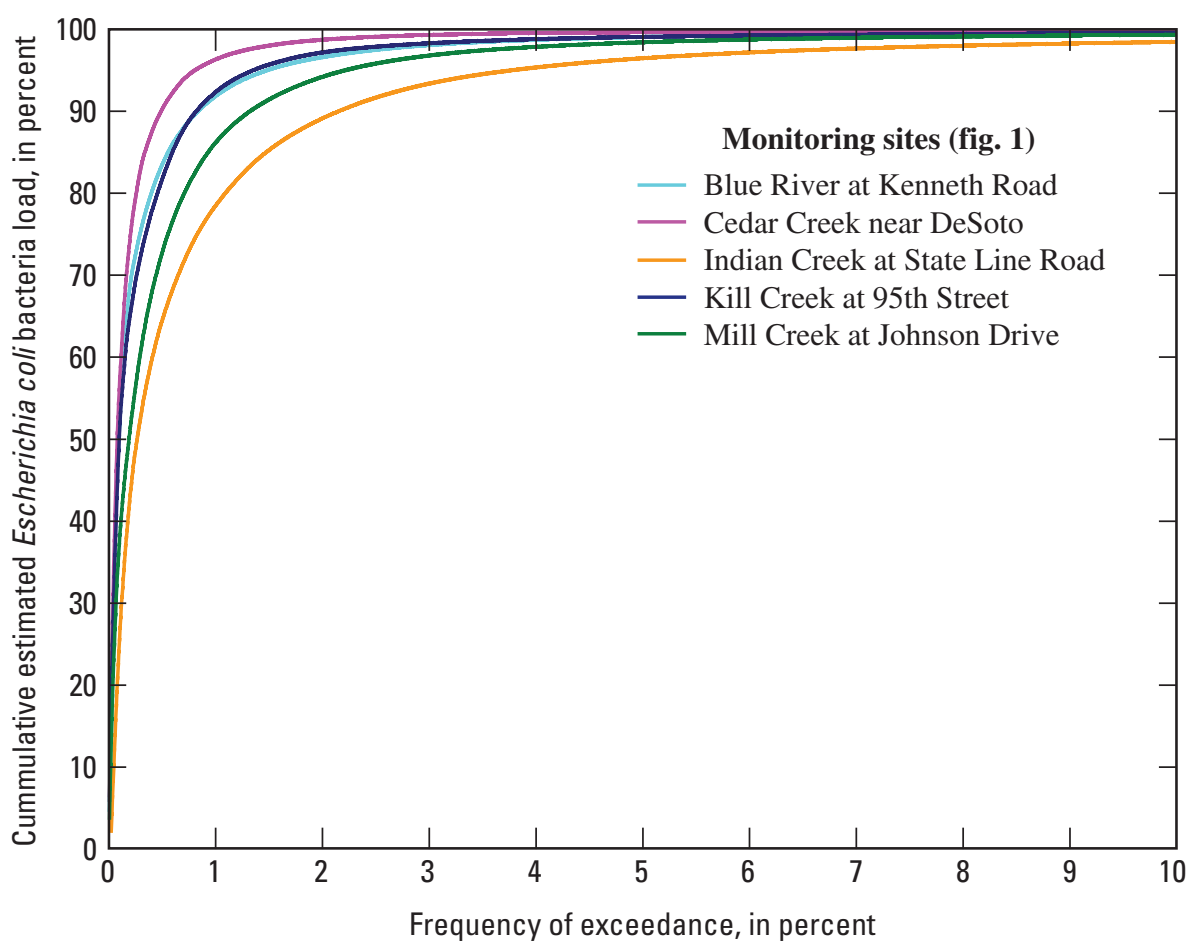

Figure 29. Cumulative estimated Escherichia coli (E. coli) bacteria loads and frequency of exceedance at five water-quality monitoring sites in Johnson County, Kansas, January 2005December 2006.

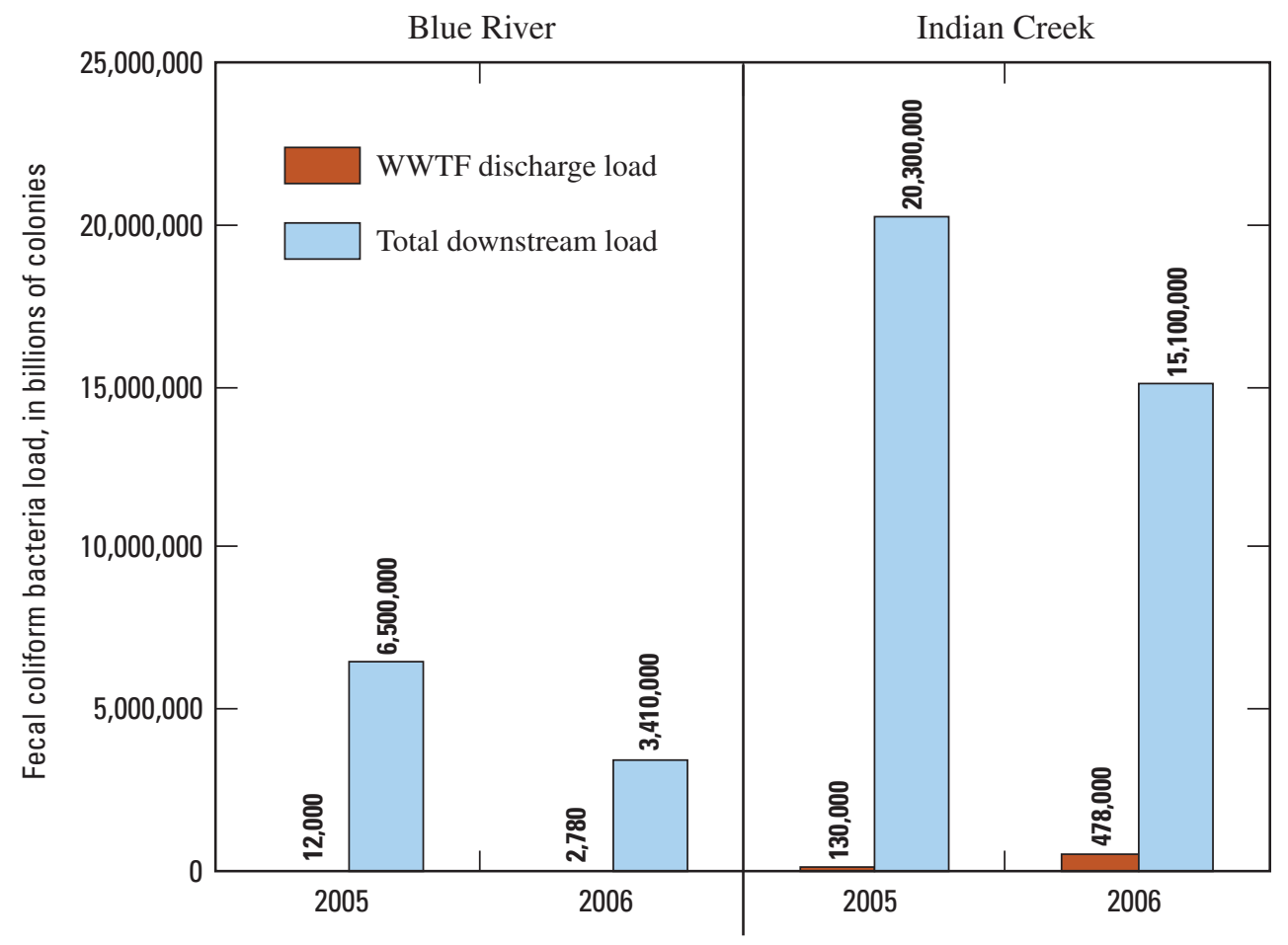

Figure 30. Total annual estimated fecal coliform bacteria loads and loads originating from wastewatertreatment-facility (WWTF) discharges to the Blue River and Indian Creek, Johnson County, Kansas, January 2005-06 (fecal coliform bacteria loads from WWTF discharges calculated from density and discharge data provided by D. Nolkemper, Johnson County Wastewater, written commun., September 2007). 
Turbidity was found to be a significant explanatory variable for total nitrogen and total phosphorus at all monitoring sites except the Cedar Creek site. The best models, as indicated by large $\mathrm{R}^{2}$ values and small RMSEs, were for the Blue River and Kill Creek sites, the two least urban watersheds and the two sites with the strongest correlations between suspended-sediment concentration and total nitrogen and phosphorus (table 9). The Cedar Creek watershed contains more impoundments than the other watersheds (indicated by the larger percentage of surface water compared to the other sites, table 1), which may interfere with relations between sediment and nutrients. By trapping sediment, impoundments also can trap nutrients that attach to sediment. Variability in the Indian Creek regression models for total nitrogen and total phosphorus likely is a result of the effects of WWTFs and changing predominant sources at that site during various streamflow conditions. Discrete-sample data indicated that the median total phosphorus concentrations at the Indian Creek site during the sample-collection period $(1.0 \mathrm{mg} / \mathrm{L}$, table 14$)$ was about 60 percent larger than median concentrations at the Cedar and Mill Creek sites (each about $0.6 \mathrm{mg} / \mathrm{L}$ ) and more than double those at the Kill Creek and the Blue River sites (each about $0.4 \mathrm{mg} / \mathrm{L})$ (table 14).

Concentrations of different nutrient species varied according to primary sources and streamflow conditions. Discrete samples collected during various streamflow conditions from October 2002 through January 2006 indicated that the largest total nitrogen concentrations occurred at the Indian Creek monitoring site during streamflows less than $200 \mathrm{ft}^{3} / \mathrm{s}$, with the exception of one sample from the Cedar Creek site and one sample from the Mill Creek site (fig. 31A). The largest proportion of nitrogen in those samples was nitrate (fig. 31B) indicating that WWTFs were likely a primary source of nitrogen during lower streamflow conditions. Ammonia, which can be toxic to aquatic life, occurred in the largest concentrations at the Indian Creek site during low flow. The largest total phosphorus concentrations at the Blue, Kill, and Mill Creek monitoring sites occurred during larger streamflows, whereas the largest total phosphorus concentrations at the Cedar and Indian Creek sites occurred during flow less than $200 \mathrm{ft}^{3} / \mathrm{s}$ (fig. 32). Larger total phosphorus concentrations during lower flows indicate WWTFs were a primary source, which is consistent with findings reported by Lee and others (2005). Larger concentrations of total nutrients during storm runoff at the Blue River and Kill Creek sites indicate that nonpoint sources are predominant in those primarily agricultural watersheds. Large concentrations of total nutrients during both base flow and storm runoff at the more urban sites indicate that the streams are affected by both point and nonpoint sources of nutrients.

Estimates indicate that about 40 percent of the total nitrogen load in 2005 and 70 percent of the total nitrogen load in 2006 originated from the WWTF discharges to the Blue River just downstream from the monitoring site. Nutrient loads from WWTFs were calculated using concentration and discharge data provided by D. Nolkemper, Johnson County Wastewater, written commun., September 2007. One-fourth (in 2005) to one-half (in 2006) of the downstream total phosphorus load in the Blue River originated from WWTF discharges. Total nitrogen load discharged from the two Indian Creek WWTFs was about 65 percent of estimated total nitrogen load at the downstream Indian Creek monitoring site in 2005 and 90 percent of the estimated downstream total nitrogen load in 2006 (fig. 33). Total phosphorus load from the Indian Creek WWTFs was 90 percent of the total phosphorus load at the downstream monitoring site in 2005 and 120 percent of the downstream total phosphorus load in 2006 (fig. 33).

Nutrient loads from the WWTFs were nearly the same in 2005 and 2006. However, because less precipitation occurred in 2006, nutrient loads originating from runoff were smaller compared to 2005. At Indian Creek, the total phosphorus load from the WWTFs exceeded the downstream total phosphorus load in 2006 primarily because of additional settling of nutrients along with sediment that occurred within the distance between the WWTF discharges and the monitoring sites, with less flushing from stormwater runoff. The largest of the two WWTFs on Indian Creek will be undergoing upgrades and is scheduled to begin biological nutrient removal in 2010 (D. Nolkemper, Johnson County Wastewater, written commun., September 2007).

\section{Pesticides}

In 2001, an estimated 1,203 million lbs of conventional pesticides were sold in the United States, the majority of which were herbicides (58 percent) and insecticides (28 percent) (Kiely and others, 2004). An estimated 76 percent of the total was used for agricultural purposes, 13 percent for commercial/industrial/government purposes, and 11 percent for home and garden purposes (Kiely and others, 2004). Nationwide studies indicate that pesticides and their degradates typically (at least 94 percent of the time) are present in water from streams throughout most of the year in both agricultural and urban watersheds (Gilliom and others, 2006). The agricultural pesticides detected most frequently and in largest concentrations were the herbicides acetochlor, alachlor, atrazine, cyanazine, and metolachlor. The most common urban pesticides were the herbicides 2,4-D, diurlon, prometon, simazine, and tebuthiuron, and the insecticides carbaryl, chlorpyrifos, and diazinon. Nationwide, pesticides seldom were found in concentrations large enough to affect humans, but often in concentrations that may have effects on aquatic life and fisheating wildlife (Gilliom and others, 2006).

Regression models for providing continuous estimates of pesticides in Johnson County streams were not developed because no continuously measured explanatory variables were found to be significant. Regression models for pesticides have been developed for other predominantly agricultural stream sites (Christensen and others, 2000; Rasmussen and others, 2005), but more mixed land uses in Johnson County watersheds likely contributed to large statistical variability in the relations between variables. 
Table 14. Results of analysis of nutrients in discrete samples collected at five continuous water-quality monitoring sites in Johnson County, northeast Kansas, October 2002 through January 2006.

[All concentrations are given in milligrams per liter; $\mathrm{N}$, nitrogen; $\mathrm{P}$, phosphorus; $<$, less than]

\section{Concentrations}

\begin{tabular}{|c|c|c|c|c|c|c|c|c|c|}
\hline $\begin{array}{c}\text { Nitrogen, } \\
\text { ammo- } \\
\text { nia, as } \mathbf{N}\end{array}$ & $\begin{array}{c}\text { Nitrogen, } \\
\text { nitrite, } \\
\text { as N }\end{array}$ & $\begin{array}{c}\text { Nitrogen, } \\
\text { nitrate, } \\
\text { as } \mathrm{N}\end{array}$ & $\begin{array}{l}\text { Nitrogen, } \\
\text { ammo- } \\
\text { nia plus } \\
\text { dissolved } \\
\text { organic } \\
\text { nitrogen, } \\
\text { as } \mathrm{N}\end{array}$ & $\begin{array}{c}\text { Nitrogen, } \\
\text { ammonia } \\
\text { plus total } \\
\text { organic } \\
\text { nitrogen, } \\
\text { as } \mathrm{N}\end{array}$ & $\begin{array}{c}\text { Nitrogen, } \\
\text { nitrite } \\
\text { plus } \\
\text { nitrate, } \\
\text { as N }\end{array}$ & $\begin{array}{c}\text { Total } \\
\text { nitrogen }\end{array}$ & $\begin{array}{c}\text { Phos- } \\
\text { phorus, } \\
\text { total }\end{array}$ & $\begin{array}{l}\text { Phos- } \\
\text { phorus, } \\
\text { dis- } \\
\text { solved }\end{array}$ & $\begin{array}{c}\text { Phospho- } \\
\text { rus, or- } \\
\text { thophos- } \\
\text { phate, } \\
\text { as } P\end{array}$ \\
\hline
\end{tabular}

\begin{tabular}{|c|c|c|c|c|c|c|c|c|c|c|}
\hline \multicolumn{11}{|c|}{ Blue River at Kenneth Road (fig. 1) } \\
\hline Number of samples & 17 & 20 & 20 & 20 & 20 & 20 & 20 & 20 & 20 & 20 \\
\hline Maximum value & .26 & .04 & 1.13 & 2.40 & 7.60 & 1.15 & 8.75 & 2.45 & .16 & .12 \\
\hline Mean & .07 & .02 & .61 & .64 & 1.84 & .63 & 2.47 & .51 & .08 & .06 \\
\hline Median & .04 & .02 & .62 & .54 & 1.52 & .64 & 2.19 & .38 & .08 & .06 \\
\hline Number of samples & 22 & 22 & 22 & 22 & 22 & 22 & 22 & 22 & 22 & 22 \\
\hline Maximum value & .12 & .08 & 7.83 & 1.00 & 3.10 & 7.90 & 9.20 & 2.43 & 2.27 & 2.22 \\
\hline Minimum value & $<.04$ & $<.02$ & .24 & .30 & .40 & .26 & 1.37 & .20 & .05 & .04 \\
\hline Mean & .06 & .03 & 1.65 & .58 & 1.30 & 1.67 & 2.97 & .69 & .41 & .38 \\
\hline Maximum value & 1.27 & .31 & 1.40 & 2.60 & 8.04 & 1.70 & 12.50 & 2.96 & 2.91 & 2.76 \\
\hline Minimum value & $<.04$ & $<.02$ & .41 & .50 & .89 & .43 & 2.30 & .54 & .07 & .06 \\
\hline Mean & .34 & .10 & 3.11 & 1.14 & 2.36 & 3.21 & 5.57 & 1.22 & .71 & .67 \\
\hline Median & .19 & .08 & 1.93 & 1.10 & 1.80 & 2.12 & 4.79 & 1.01 & .41 & .38 \\
\hline \multicolumn{11}{|c|}{ Kill Creek at 95th Street (fig. 1) } \\
\hline Number of samples & 22 & 25 & 25 & 25 & 25 & 25 & 25 & 25 & 25 & 25 \\
\hline Maximum value & .17 & .05 & 1.97 & 1.30 & 6.20 & 2.02 & 7.31 & 2.14 & .76 & .73 \\
\hline Minimum value & $<.04$ & $<.02$ & .03 & .20 & .30 & $<.05$ & .35 & .09 & .03 & .02 \\
\hline Mean & .07 & .03 & 1.91 & .54 & 1.73 & 1.94 & 3.67 & .85 & .32 & .29 \\
\hline Median & .05 & .02 & 1.35 & .50 & 1.10 & 1.37 & 2.74 & .62 & .19 & .18 \\
\hline
\end{tabular}


(A) Total nitrogen

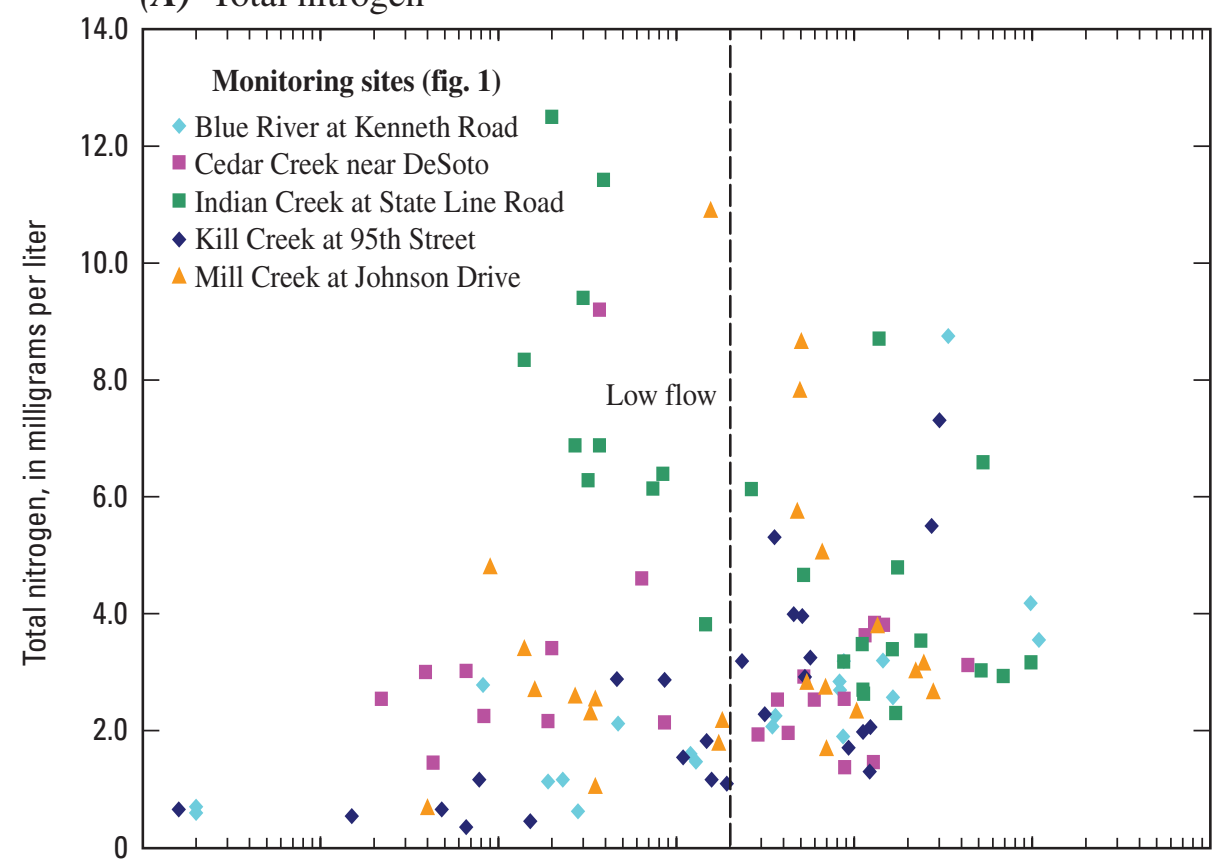

(B) Nitrate as nitrogen

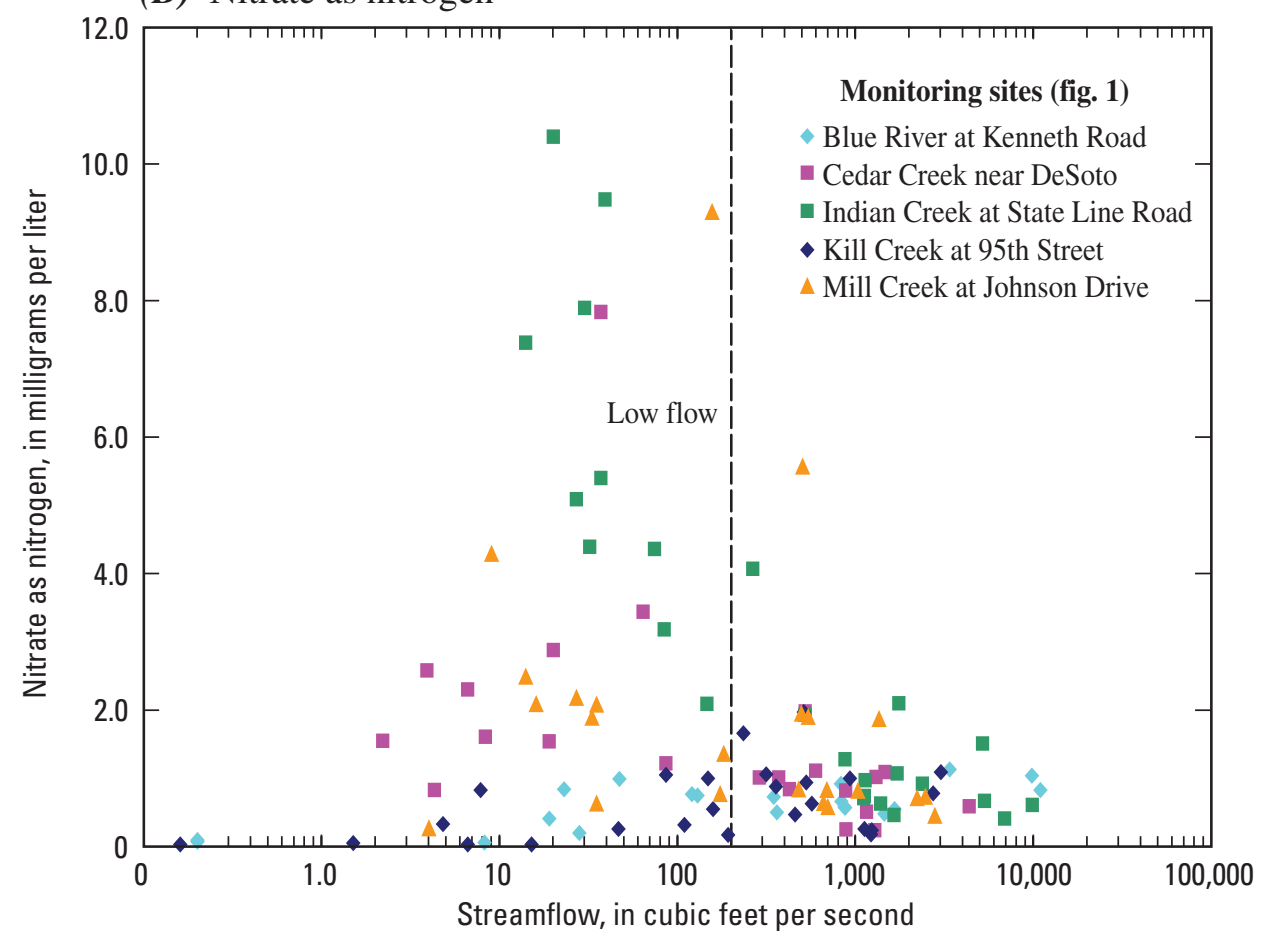

Figure 31. Concentrations of $(A)$ total nitrogen and $(B)$ nitrate in relation to streamflow at five waterquality monitoring sites in Johnson County, Kansas, October 2002-January 2006. 


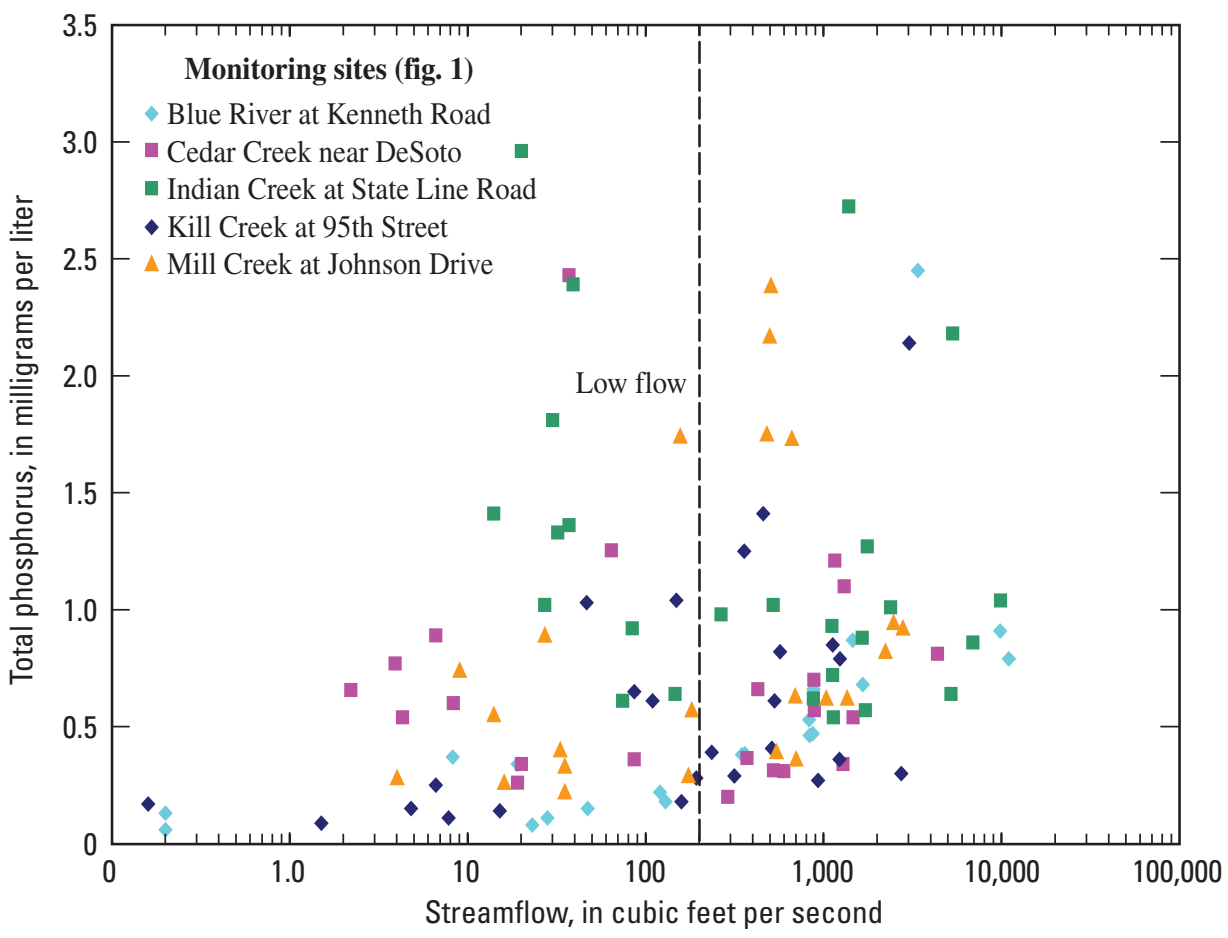

Figure 32. Concentrations of total phosphorus in relation to streamflow at five water-quality monitoring sites in Johnson County, Kansas, October 2002-January 2006.

Discrete samples collected for the study described in this report indicated that many of the same pesticides frequently found nationwide also were most common in Johnson County streams (table 15). Atrazine (an herbicide often used in crop production) was common at all monitoring sites. Prometon (an extensively used urban herbicide) also was detected in more than 90 percent of samples at each site. Metolachlor (a common agricultural herbicide) was found in the majority of samples at all sites except Kill Creek, where it was detected in about two-thirds of the samples. Simazine (another extensively used herbicide usually associated with urban uses) was found in all samples from all five sites but was detected most frequently in samples from the Cedar Creek site. The largest concentrations of all pesticides occurred in samples collected during storm runoff, usually in the spring.

Atrazine was the most commonly detected pesticide at all five monitoring sites. However, concentrations in the more agricultural watersheds (Blue River, Cedar Creek, and Kill Creek) were largest, exceeding the KDHE aquatic-life criterion of $3.0 \mu \mathrm{g} / \mathrm{L}$ in one sample from the Blue River, two samples from Cedar Creek, and three samples from Kill Creek. Each exceedance occurred during storm runoff in April, May, or June. Larger concentrations of atrazine in Indian Creek samples collected during base flow compared to stormflow indicated that a major source of atrazine in that watershed is wastewater discharge, likely originating from municipal water supply, as first proposed by Lee and others (2005). The primary sources of drinking water in Johnson County are the Kansas and Missouri Rivers, both of which drain large agricultural watersheds and are known to contain atrazine most of the year (Goolsby and Battaglin, 1993; Rasmussen and others, 2005). Treated water contained atrazine concentrations ranging from 0.2 to $0.6 \mu \mathrm{g} / \mathrm{L}$ (Water-One, 2004). In addition, studies have found atmospheric transport from agricultural areas can be a notable source of atrazine in streams (Cromwell and Thurman, 2000; Hampson and others, 2000).

\section{Watershed Characteristics Affecting Water Quality in Johnson County Streams}

Hydrologic conditions, land use, contaminant sources, and human activity are the most important factors affecting water quality in Johnson County streams. Watershed characteristics, including geology, soils, and topography also affect water quality. Hydrologic conditions determine streamflow during storm runoff and affect both point and nonpoint contaminants in streams. Streamflow is the transport mechanism for delivering and moving water-quality constituents in streams. Streamflow characteristics affect constituent concentrations, rate of delivery and transport (volume and velocity), and constituent loads (volume). Precipitation, primarily the amount, frequency, and intensity of rainfall, is the fundamental factor contributing to streamflow and affecting 


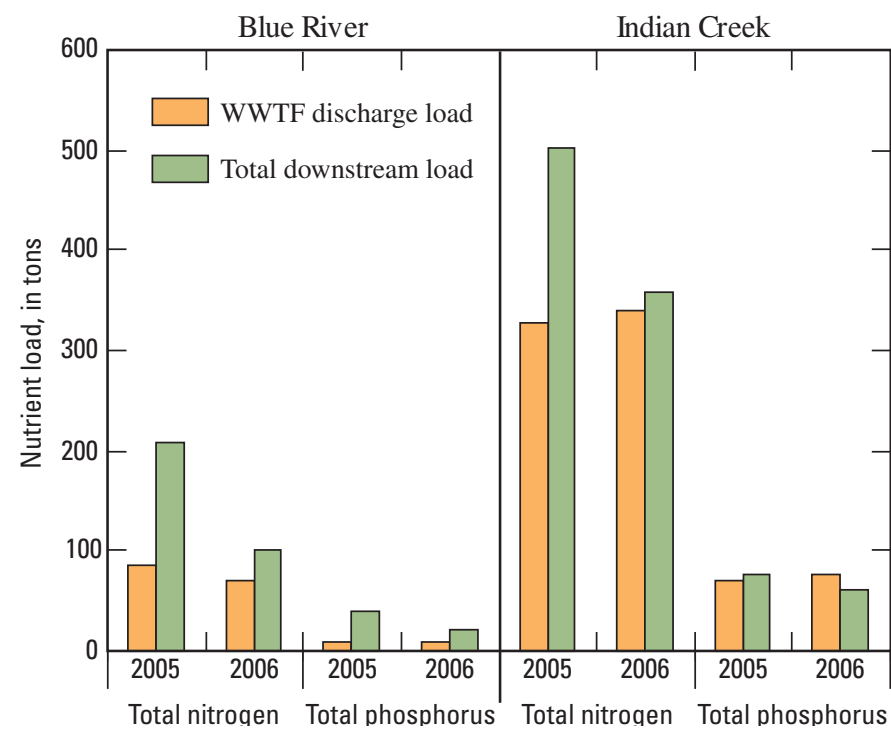

Figure 33. Annual estimated total nitrogen and total phosphorus loads and loads originating from wastewater-treatment facility (WWTF) discharges to the Blue River and Indian Creek, Johnson County, Kansas, 2005-06 (nutrient loads from wastewater-treatment facility discharges calculated from concentration and discharge data provided by D. Nolkemper, Johnson County Wastewater, written commun., September 2007).

transport of nonpoint contaminant sources. Because just two complete calendar years (2005 and 2006) of continuous data have been collected at all five Johnson County monitoring sites to date, and four complete calendar years (2003, 2004, $2005,2006)$ of continuous data have been collected at two sites (Cedar and Mill Creeks), thorough analysis of the effects of hydrologic variability on stream-water quality depends on additional data collection and interpretation. However, data collected in 2004 and 2005 indicate that just a few large storm runoffs lasting a few days can account for more than 50 percent of constituent loads in streams, particularly for sediment, chloride from road-salt runoff, and bacteria.

Besides precipitation, the other major source of streamflow in Johnson County is wastewater effluent. WWTFs play an important role in streamflow by sustaining base flow. The Indian Creek monitoring site is less than $1.4 \mathrm{mi}$ downstream from the largest quantity of WWTF discharge of the five sites monitored. Lee and others (2005) found that during base flow, the majority of streamflow at three of the continuously monitored sites (Cedar, Indian, and Kill Creeks) originated from WWTF discharges as far as 13 mi upstream, and streamflow at the Mill Creek monitoring site also may often consist primarily of WWTF discharge, but rainfall during data collection may have affected estimates. At the Cedar, Indian, Kill, and Mill Creek sites, it is likely that streamflow was affected by WWTF discharge during normal flow as well. Normal flow could be considered that flow within the 25th and 75th percentile (fig. 4; http://water.usgs.gov/waterwatch). In this study, only the Blue River site was unaffected by WWTF discharge at the monitoring site. However, wastewater does discharge into the Blue River just downstream from the monitoring site, and therefore, water quality is expected to be different downstream from the monitoring site.

A number of factors associated with urbanization can affect water quality. Urban runoff and treated wastewater may have increased concentrations of nutrients, pesticides, metals, organic compounds, and dissolved ions (Heany and Huber, 1984; Zampella, 1994; Paul and Meyer, 2001). Lower infiltration capacity of watersheds in urban environments with greater amounts of impervious surfaces may inhibit the ability of streams to sustain base flow (Finkenbine and others, 2000; Dodds, 2002). Urbanization affects sediment supply and transport differently during the construction phase and postconstruction phase, as summarized by Paul and Meyer (2001). During the construction phase, erosion of exposed soils leads to larger sediment loads (Leopold, 1968). This effect intensifies in more sloped watersheds and generally occurs during a few large floods (Wolman, 1967). The increase in sediment supply leads to bed aggradation, and stream depths may decrease resulting in decreased channel capacity, larger floods, and overbank sediment deposition (Wolman, 1967). The aggradation phase is followed by an erosional phase, during which channel erosion is the largest source of sediment. Increases in impervious surface area substantially increase the frequency or volume of bankfull floods leading to a general deepening (incision) and widening of the channel (Booth, 1990). After incision, channels migrate laterally and bank erosion begins (Trimble, 1997). In developed urban streams, the majority of sediment being transported originates from channel erosion rather than hillside erosion (Trimble, 1997).

Impervious surfaces produce overland flow and large quantities of runoff even at moderate rainfall intensities (Arnold and Gibbons, 1996). Impervious surface area also has been found to be highly correlated with urban intensity and a good integrator of urban land-use conditions (McMahon and Cuffney, 2000), making it a useful surrogate for urban intensity.

In Johnson County, as impervious surface area increased, so did total annual yield for most water-quality constituents in 2005 and 2006. Examining suspended-sediment, chloride, and E. coli bacteria yields (fig. 34), the three monitoring sites with less than 4 percent impervious surface area (table 1) clustered together with smaller yields, and Indian Creek with 24 percent impervious surface area, had considerably larger yields. Suspended sediment may increase in urban areas because of more exposed soils at construction sites, increased streamflow velocities contributing to more streambed and bank erosion, lack of riparian habitats for protecting soils from erosion, and settling sediment from water. Urban sources of chloride (road-salt runoff, WWTF discharge, industrial runoff) contributed more than nonurban sources (geology). Urban sources of E. coli bacteria (leaky sewer lines, pet waste, wildlife, WWTF discharges and bypasses, and unauthorized dumping) also generally contributed more than nonurban sources (livestock, leaky septic systems, and wildlife). 
Table 15. Results of analysis of pesticides in discrete samples collected at five continuous water-quality monitoring sites in Johnson County, northeast Kansas, October 2002 through January 2006.

[( ), laboratory reporting level; <, less than; E, estimated; --, not calculated because more than half of the values were less than the detection limit]

\begin{tabular}{|c|c|c|c|c|c|c|c|c|}
\hline $\begin{array}{c}\text { Monitoring site } \\
\text { (fig. 1) and summary } \\
\text { statistics }\end{array}$ & $\begin{array}{c}\text { 1-Naphthol, } \\
\text { water, filtered } \\
\text { (0.7-micron } \\
\text { glass-fiber } \\
\text { filter), } \\
\text { recoverable, } \\
\text { micrograms } \\
\text { per liter }(0.04)\end{array}$ & $\begin{array}{c}\text { 2-Chloro- } \\
\text { 2',6'-diethy- } \\
\text { lacetanilide, } \\
\text { water, filtered, } \\
\text { recoverable, } \\
\text { micrograms } \\
\text { per liter (0.01) }\end{array}$ & $\begin{array}{c}\text { 2-Chloro- } \\
\text { 4-isopropylam- } \\
\text { ino-6-amino- } \\
\text { s-triazine, } \\
\text { water, filtered, } \\
\text { recoverable, } \\
\text { micrograms } \\
\text { per liter }(0.06)\end{array}$ & $\begin{array}{c}\text { 2-Ethyl-6- } \\
\text { methylani- } \\
\text { line, water, } \\
\text { filtered, } \\
\text { recoverable, } \\
\text { micrograms } \\
\text { per liter } \\
(0.01)\end{array}$ & $\begin{array}{l}\text { 3,4-Dichloro- } \\
\text { aniline, } \\
\text { water, } \\
\text { filtered, } \\
\text { recoverable, } \\
\text { micrograms } \\
\text { per liter } \\
(0.006)\end{array}$ & $\begin{array}{c}\text { 4-Chloro-2- } \\
\text { methylphe- } \\
\text { nol, water, } \\
\text { filtered, } \\
\text { recoverable, } \\
\text { micrograms } \\
\text { per liter } \\
(0.005)\end{array}$ & $\begin{array}{l}\text { Acetochlor, } \\
\text { water, } \\
\text { filtered, } \\
\text { recover- } \\
\text { able, } \\
\text { micrograms } \\
\text { per liter } \\
(0.006)\end{array}$ & $\begin{array}{c}\text { Alachlor, } \\
\text { water, } \\
\text { filtered, } \\
\text { recoverable, } \\
\text { micrograms } \\
\text { per liter } \\
(0.006)\end{array}$ \\
\hline \multicolumn{9}{|c|}{ Blue River at Kenneth Road } \\
\hline Number of samples & 21 & 21 & 21 & 21 & 20 & 21 & 21 & 21 \\
\hline Number of detections & 1 & 1 & 21 & 0 & 9 & 9 & 13 & 10 \\
\hline Maximum value & $<.088$ & .018 & E.122 & $<.010$ & .096 & E.010 & .325 & .731 \\
\hline Minimum value & E. .017 & $<.005$ & E.006 & $<.005$ & E.003 & E.002 & E.005 & E.004 \\
\hline Mean value & -- & -- & .047 & -- & -- & -- & .043 & -- \\
\hline Number of detections & 1 & 0 & 21 & 0 & 18 & 0 & 9 & 3 \\
\hline Maximum value & $<.088$ & $<.007$ & E.222 & $<.010$ & E.075 & E.009 & .401 & $<.008$ \\
\hline Minimum value & E. .017 & $<.005$ & $<.010$ & $<.005$ & $<.005$ & E.003 & $<.006$ & $<.005$ \\
\hline Mean value & -- & -- & .077 & -- & .028 & -- & -- & -- \\
\hline Median value & -- & -- & .050 & -- & .029 & -- & -- & -- \\
\hline \multicolumn{9}{|c|}{ Indian Creek at State Line Road } \\
\hline Number of samples & 23 & 23 & 23 & 23 & 22 & 23 & 23 & 23 \\
\hline Number of detections & 6 & 0 & 18 & 0 & 18 & 9 & 9 & 7 \\
\hline Maximum value & $<.088$ & $<.007$ & Е .092 & $<.010$ & .146 & E .017 & .202 & .058 \\
\hline Minimum value & E.006 & $<.005$ & E.002 & $<.005$ & $<.005$ & E. .004 & $<.006$ & $<.005$ \\
\hline Minimum value & E.003 & $<.005$ & E.010 & $<.005$ & E.003 & $<.005$ & $<.006$ & $<.005$ \\
\hline Mean value & -- & -- & .063 & -- & -- & -- & -- & -- \\
\hline Median value & -- & -- & .030 & -- & -- & -- & -- & -- \\
\hline \multicolumn{9}{|c|}{ Mill Creek at Johnson Drive } \\
\hline Number of samples & 21 & 21 & 22 & 21 & 21 & 21 & 22 & 22 \\
\hline Number of detections & 5 & 0 & 18 & 0 & 13 & 9 & 8 & 7 \\
\hline Maximum value & $<.088$ & $<.007$ & E.066 & $<.010$ & .513 & E.018 & .147 & .037 \\
\hline Minimum value & E.005 & $<.005$ & $<.006$ & $<.005$ & $<.005$ & E.002 & E.004 & $<.005$ \\
\hline Mean value & -- & -- & .027 & -- & .054 & -- & -- & -- \\
\hline Median value & -- & -- & .022 & -- & .014 & -- & -- & -- \\
\hline
\end{tabular}


Table 15. Results of analysis of pesticides in discrete samples collected at five continuous water-quality monitoring sites in Johnson County, northeast Kansas, October 2002 through January 2006._-Continued

[( ), laboratory reporting level; <, less than; E, estimated; --, not calculated because more than half of the values were less than the detection limit]

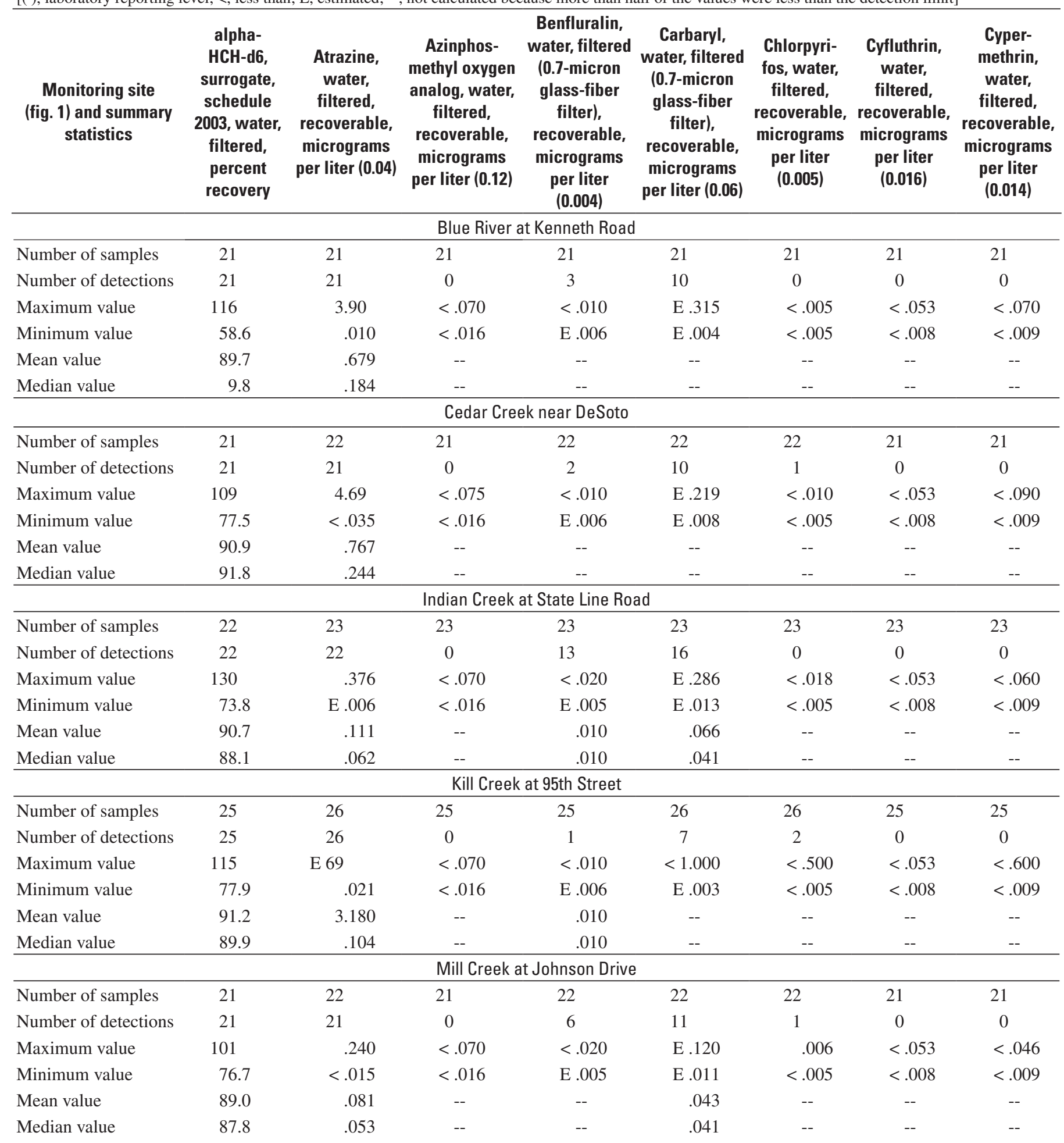


Table 15. Results of analysis of pesticides in discrete samples collected at five continuous water-quality monitoring sites in Johnson County, northeast Kansas, October 2002 through January 2006.-Continued

[( ), laboratory reporting level; <, less than; E, estimated; --, not calculated because more than half of the values were less than the detection limit]

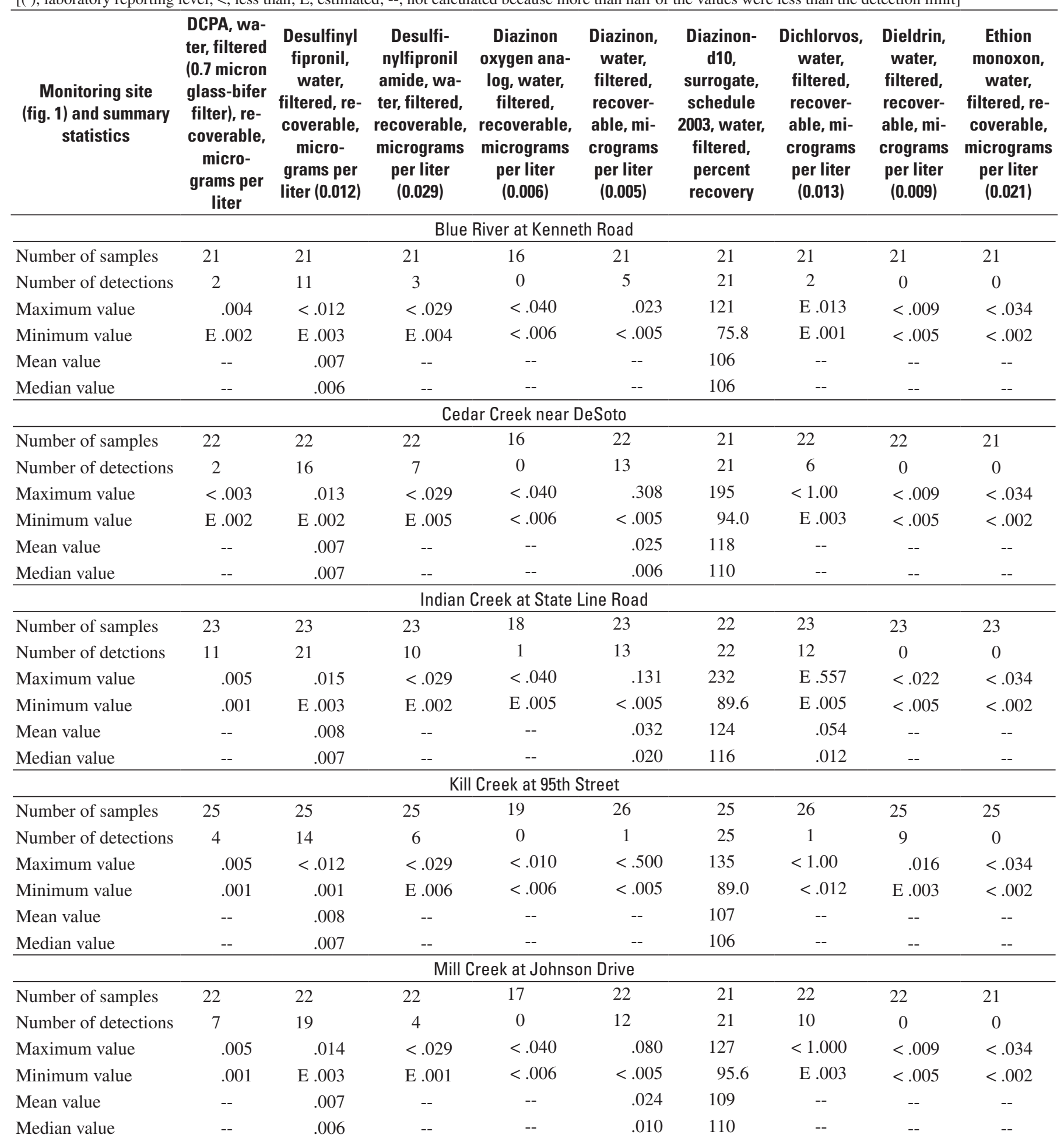


Table 15. Results of analysis of pesticides in discrete samples collected at five continuous water-quality monitoring sites in Johnson County, northeast Kansas, October 2002 through January 2006._-Continued

[( ), laboratory reporting level; <, less than; E, estimated; --, not calculated because more than half of the values were less than the detection limit]

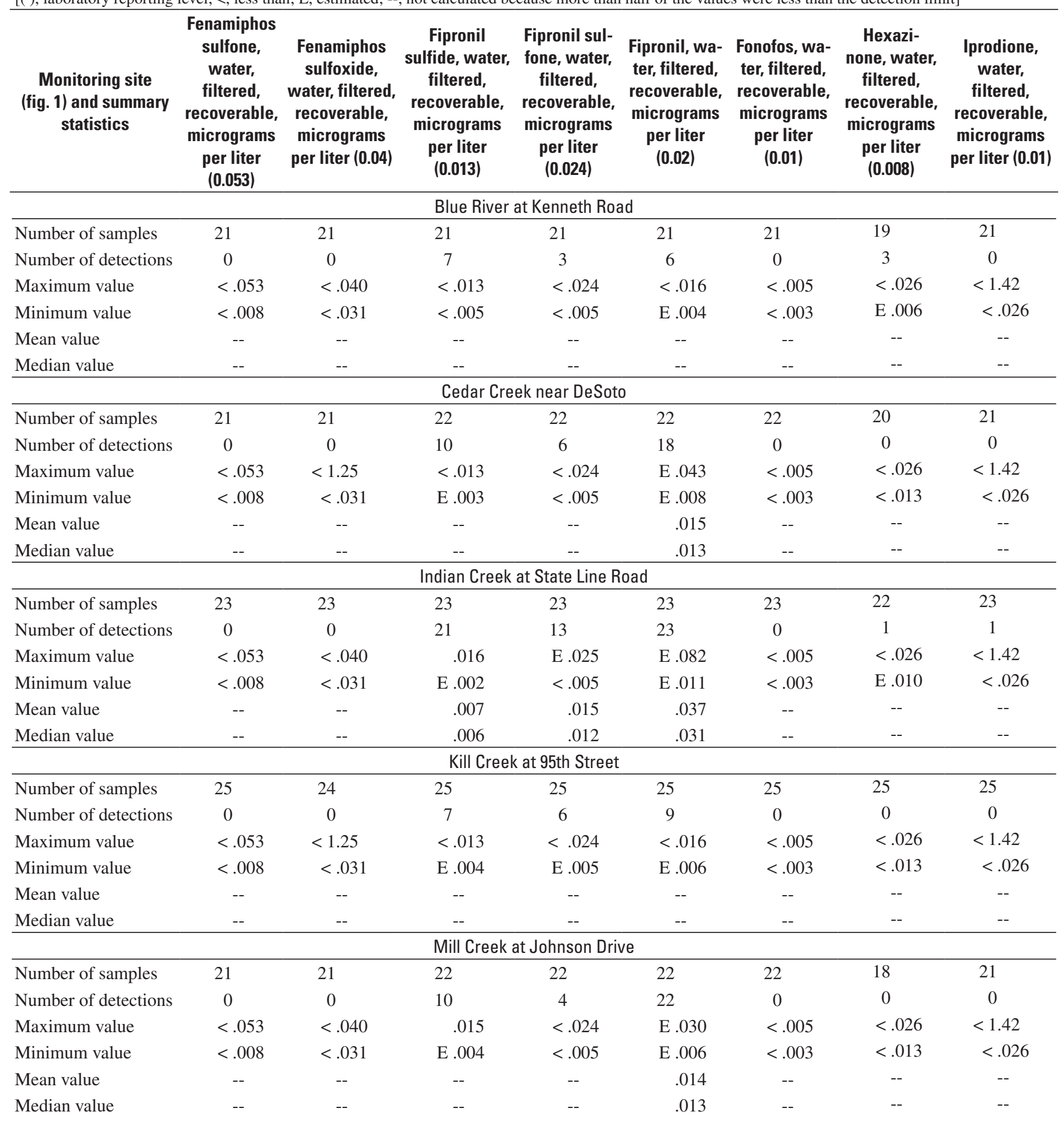


Table 15. Results of analysis of pesticides in discrete samples collected at five continuous water-quality monitoring sites in Johnson County, northeast Kansas, October 2002 through January 2006.-Continued

[( ), laboratory reporting level; <, less than; E, estimated; --, not calculated because more than half of the values were less than the detection limit]

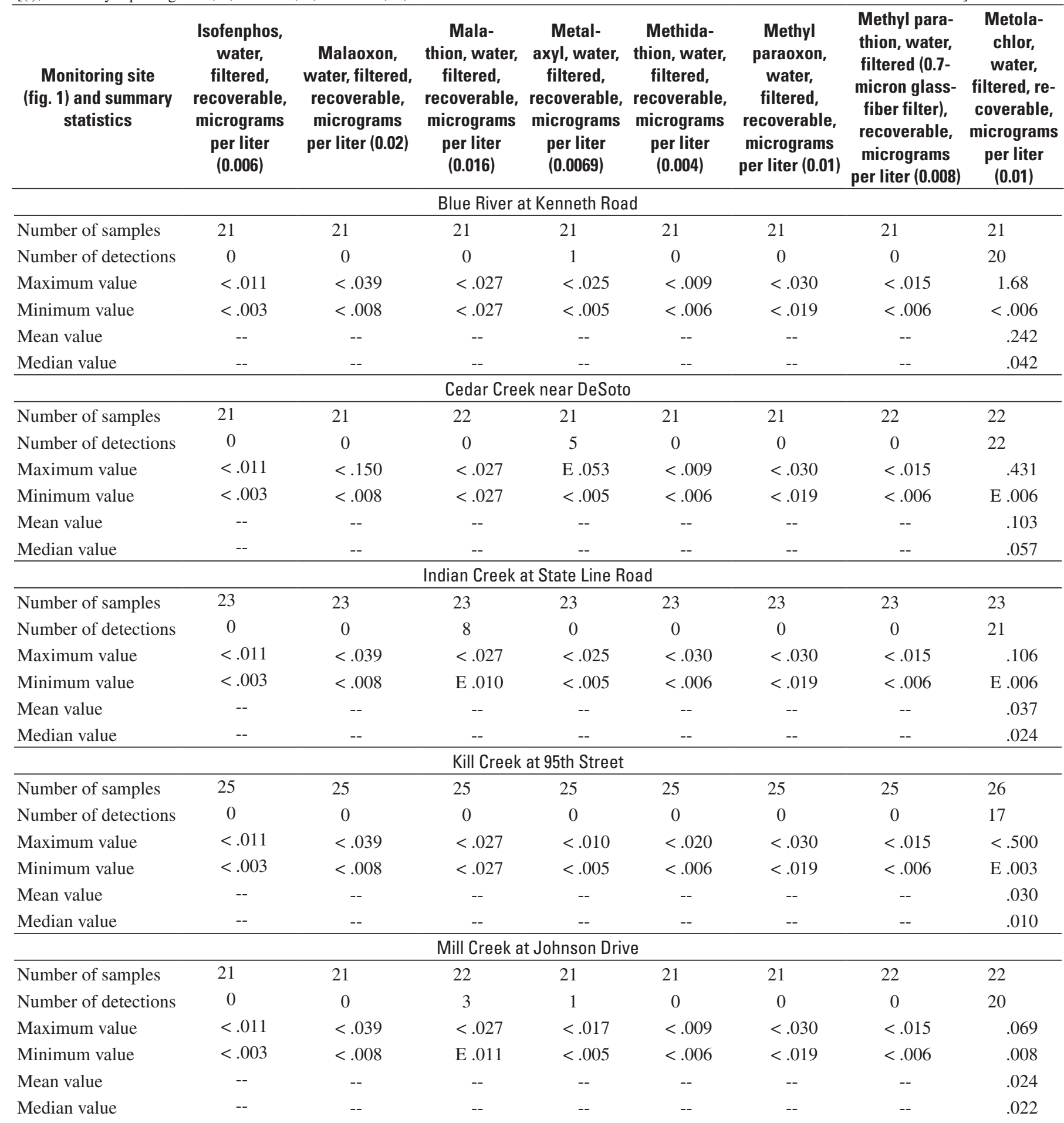


Table 15. Results of analysis of pesticides in discrete samples collected at five continuous water-quality monitoring sites in Johnson County, northeast Kansas, October 2002 through January 2006._-Continued

[( ), laboratory reporting level; <, less than; E, estimated; --, not calculated because more than half of the values were less than the detection limit]

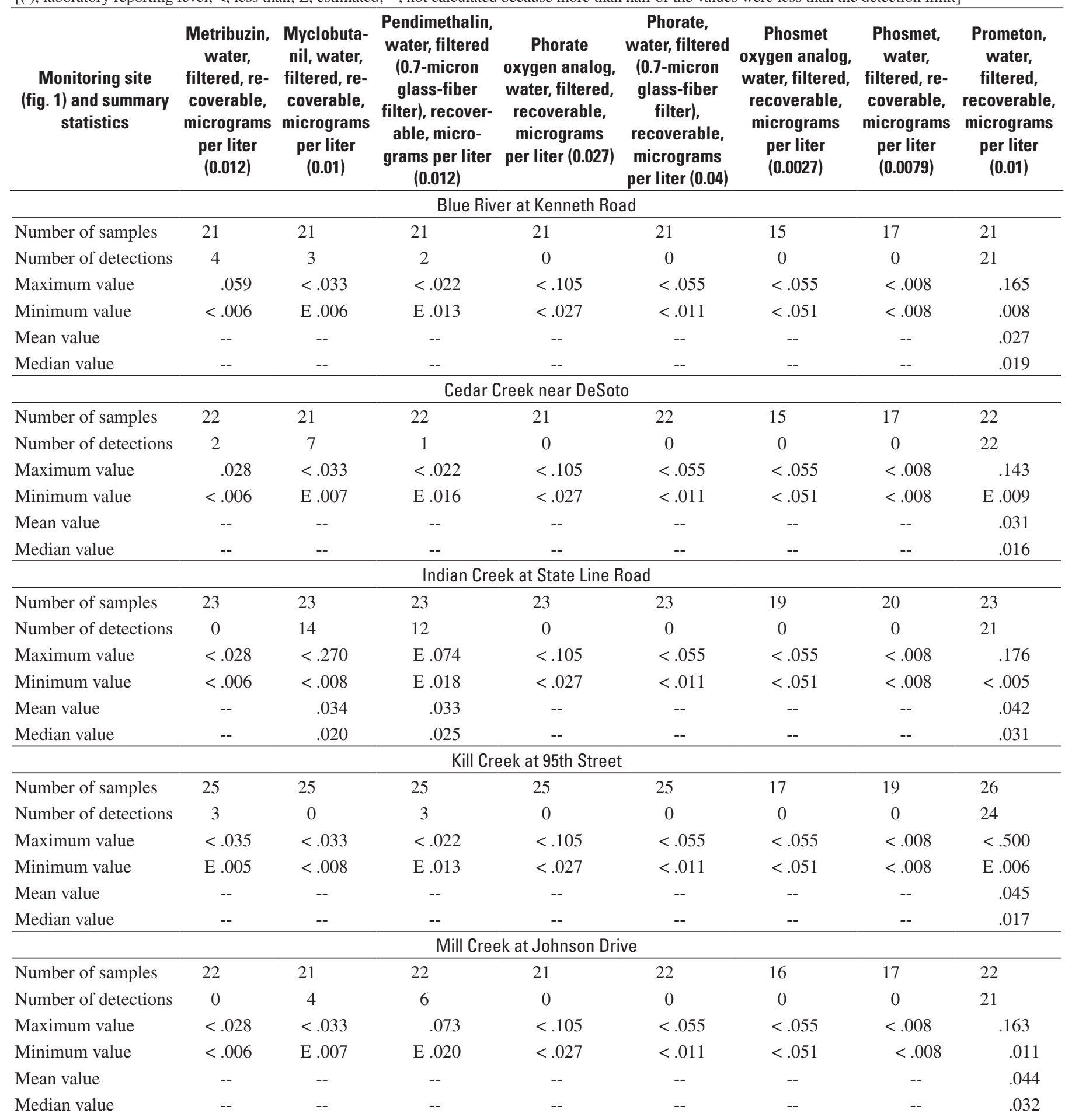


Table 15. Results of analysis of pesticides in discrete samples collected at five continuous water-quality monitoring sites in Johnson County, northeast Kansas, October 2002 through January 2006.—Continued

[( ), laboratory reporting level; <, less than; E, estimated; --, not calculated because more than half of the values were less than the detection limit]

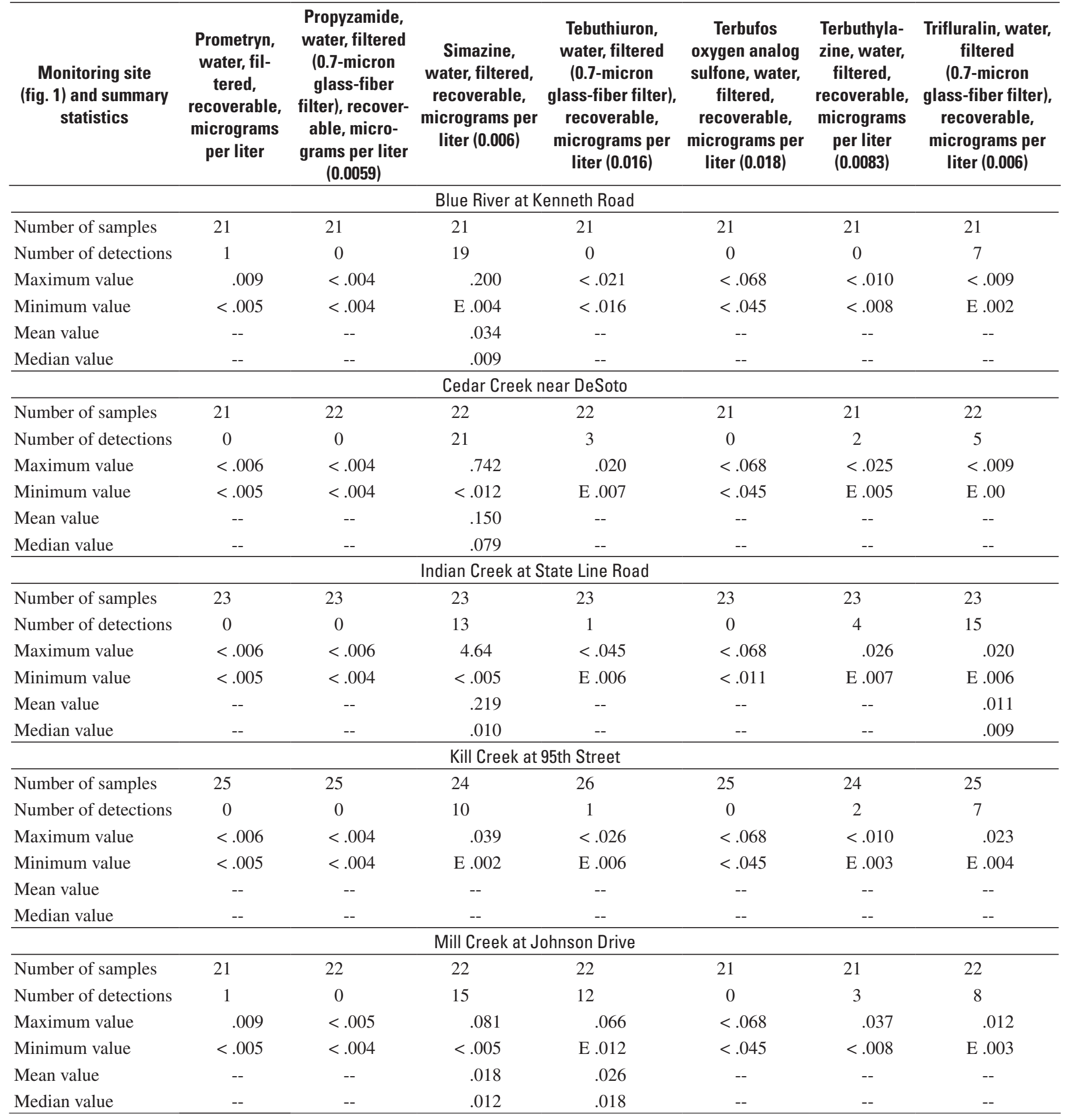



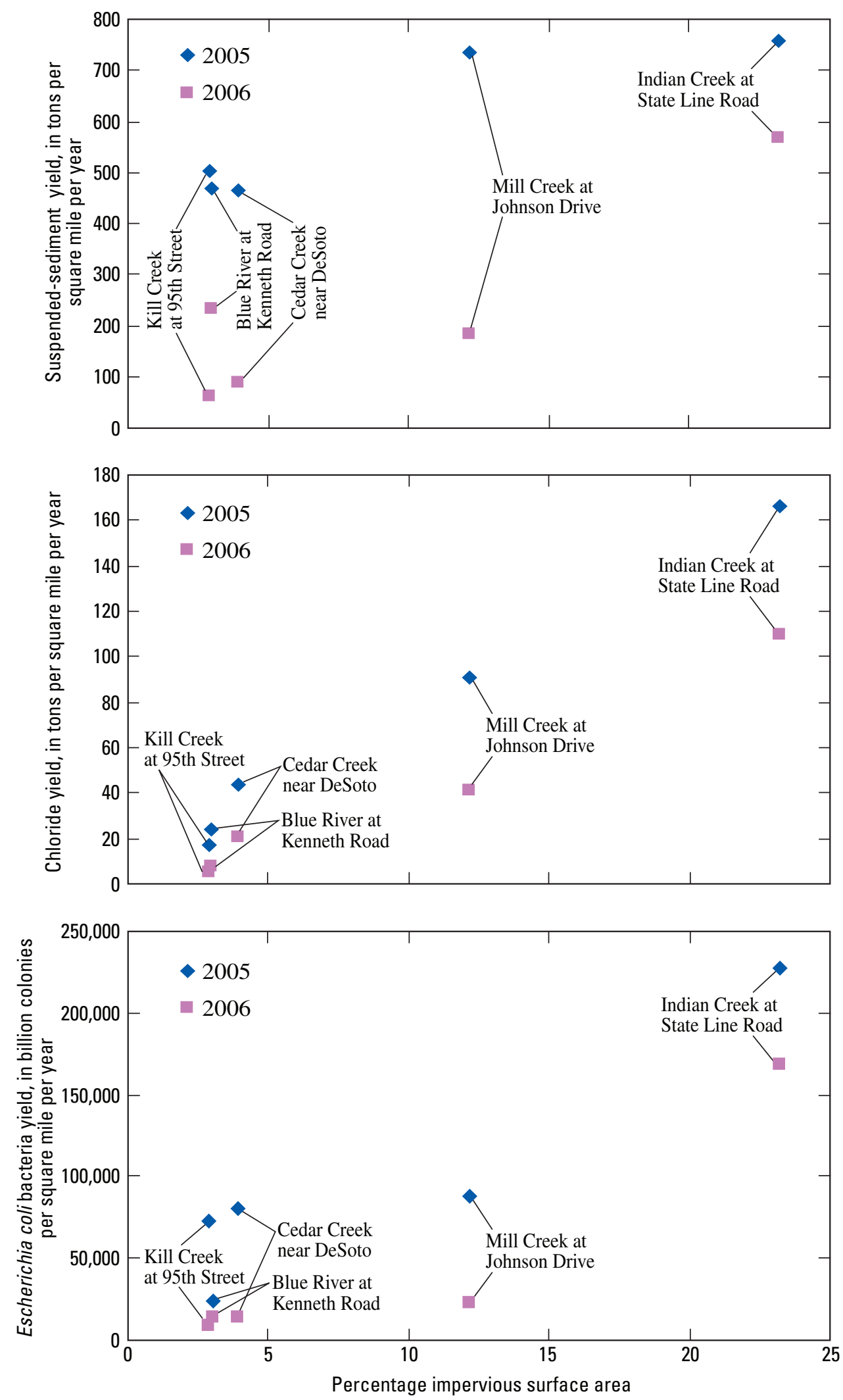

Figure 34. Constituent yields and impervious surface area at five water-quality monitoring sites in Johnson County, Kansas, 2005-06. 
Most measured contaminants in Johnson County streams, including suspended sediment, indicator bacteria, some nutrients, and most pesticides, originate primarily from nonpoint sources, primarily overland flow during storm runoff. Each can be expected to increase in concentration substantially during storm runoff and decrease again some time after streamflow recedes. Although concentrations in the water column decrease following storms, contaminants can remain in the stream and accumulate in streambed sediment (Lee and others, 2005).

Atmospheric deposition may be another important nonpoint source for some water-quality constituents in Johnson County streams. Nationwide, the most common air pollutants that degrade water quality are nitrogen compounds, mercury and other metals, pesticides, and industrial emissions such as dioxins, furans, polycyclic aromatic hydrocarbons (PAHs) and polychlorinated biphenyls (PCBs) (U.S. Environmental Protection Agency, 2004a). In 2004, an estimated 12 lb/acre of nitrogen from nitrate and ammonium was deposited in precipitation over eastern Kansas (National Atmospheric Deposition Program, 2005).

WWTFs are a primary point source of some contaminants in Johnson County streams, and their discharges affect streams most during base flow (Lee and others, 2005). Generally, wastewater discharges affect receiving streams by introducing oxygen-demanding substances, pathogens, nutrients, and organic chemicals to the stream (U.S. Environmental Protection Agency, 2004b). Oxygen-demanding substances, such as organic matter and ammonia, consume natural supplies of dissolved oxygen in the stream, and can result in insufficient supplies to support fish and other aquatic life. Dissolved oxygen at the Indian Creek monitoring site, which is most affected by WWTFs discharge, was less than the KDHE aquatic-life criterion of $5.0 \mathrm{mg} / \mathrm{L}$ about 20 percent of the time and more than any other site (fig. 9A), indicating that WWTF discharge likely was affecting aquatic life at that site. E. coli bacteria densities were largest at the Indian Creek site compared to other sites (fig. 26). In addition, nutrients including total phosphorus were largest at that site (table 14).

Contaminants in streams that originate from WWTFs, including some nutrients and wastewater compounds (Lee and others, 2005), generally decrease during storm runoff as a result of dilution. Exceptions may occur during storms when large volumes of water exceed the WWTF's treatment capacity, resulting in temporary discharge of effluent that has not been fully treated. Although WWTFs contribute a relatively small portion of the total load of water-quality constituents, the primary concern to aquatic environments is large concentrations during base and normal flow that may extend for long periods of time.

Although urbanization falls into the general category of human activity, additional types of human activities also can affect water quality. Physical alterations (such as channelization, impoundments, irrigation), chemical alterations (such as application of fertilizers and pesticides, septic systems), and biological alterations (such as forest and agricultural management, import of exotic species) change the hydrologic cycle and water-quality characteristics of streams (Peters and Meybeck, 2000). One example of a human activity in Johnson County that is not exclusively associated with urbanization but has a notable effect on water quality is the seasonal application of pesticides. The largest concentrations of all pesticides occurred in samples collected during storm runoff, usually in the spring.

Johnson County has developed a stormwater management plan that describes implementation of BMPs to reduce adverse effects of stormwater runoff on water quality as required by the NPDES program. BMPs can improve stormwater quality by reducing or removing sediment, metals, bacteria, nutrients, organic compounds and other substances. BMPs can be nonstructural, such as maintaining native areas and flood-plain vegetation for filtering runoff, or structural, such as constructing ponds, wetlands, and infiltration devices (Mid-America Regional Council and American Public Works Association, 2003). In addition, TMDLs developed by the Kansas Department of Health and Environment describe recommended actions to address water-quality impairments. Activities recommended in Johnson County TMDLs include installing grass buffer strips, maintaining riparian areas, and reducing peak streamflows and associated sediment and nutrient loads (Kansas Department of Health and Environment, 2007), as well as upgrading nutrient treatment in wastewater facilities and repairing faulty septic systems (Kansas Department of Health and Environment, 2006b). Implementation of BMPs is expected to affect water quality of Johnson County streams over time.

\section{Summary and Conclusions}

Johnson County is one of the most rapidly developing counties in Kansas. According to the U.S. Census Bureau, population increased by about 90 percent in the last 25 years, from 270,269 in 1980 to an estimated 516,731 in 2006. Population growth and expanding urban land use affect the quality of county streams, which are important for human and environmental health, water supply, recreation, and aesthetic value. Urbanization generally affects streams by altering hydrology, geomorphology, chemistry, and biology.

Continuous water-quality monitors and streamflowgaging stations were installed on five different streams in Johnson County, northeast Kansas, to estimate water-quality constituent concentrations, densities, loads, and yields using continuous in-stream sensor measurements and to characterize differences relative to hydrologic conditions, contributing drainage area, land use, point and nonpoint sources, and human activity. Monitoring sites were located as far downstream as possible in the largest watersheds in the county and designed to represent urban, urbanizing, and nonurban land uses. Two of the sites, Cedar Creek near DeSoto and Mill Creek at Johnson Drive, were installed in October 2002, and 
three sites, Blue River at Kenneth Road, Indian Creek at State Line Road, and Kill Creek at 95th Street, were installed in March 2004. All sites were operated through December 2006.

Each site was equipped with a water-quality monitor that provided continuous in-stream measurements of specific conductance, $\mathrm{pH}$, water temperature, turbidity, and dissolved oxygen. The data are available in real time on USGS Web pages (http:// ks.water.usgs.gov/Kansas/rtqw/ and http://waterdata.usgs.gov/ks/nwist). In addition to continuous monitoring, discrete water samples were collected manually from each site. Samples were analyzed for nutrients, indicator bacteria, sediment, pesticides, and other constituents. Regression analysis was used to develop relations between the continuous sensor measurements, streamflow, time, and discretely sampled constituent concentrations. Continuous (hourly) constituent concentrations were estimated using equations from the regression models. Constituent loads and yields were estimated from continuous concentration estimates, continuous streamflow data, and respective drainage-basin area. Most siteto-site comparisons were made using the period March 2004 through December 2006 when monitors were operating at all five sites simultaneously. Estimated annual loads and yields were evaluated for January 2005 through December 2006.

In-stream measurements of streamflow, specific conductance, $\mathrm{pH}$, water temperature, turbidity, and dissolved oxygen (DO) varied with precipitation, season, time of day, and contributing sources. Hourly streamflow ranged from less than $1 \mathrm{ft}^{3} / \mathrm{s}$ in Kill Creek (2004, 2005, and 2006) and the Blue River (2005 and 2006) to $19,200 \mathrm{ft}^{3} / \mathrm{s}$ in the Blue River (2004). The largest median streamflow from March 2004 through 2006 occurred in Indian Creek, which is the second largest drainage basin $\left(63.1 \mathrm{mi}^{2}\right)$ and the most urban of the five monitored basins. Kill Creek, the smallest and least urban of the monitored basins $\left(48.6 \mathrm{mi}^{2}\right)$, generally had the smallest streamflow except during base flows when Blue River streamflow was smallest. Annual differences in streamflow can be attributed to differences in precipitation. Average annual precipitation in 2004 and 2005 was close to the historical mean annual precipitation of 40 in. Precipitation in 2006 was less than normal, ranging from about 30 to $35 \mathrm{in}$.

Rapid changes in specific conductance and turbidity associated with changes in streamflow occurred in Johnson County streams. From March 2004 through 2006, specific conductance was nearly always largest at the Indian Creek site, followed by the Mill Creek site, the two most urban sites and the two sites with the largest WWTF contribution. Both sites showed sharp increases in specific conductance during 15 percent of the time, as a result of road-salt application. Turbidity ranged from less than 2 FNUs at all sites annually to about 2,000 FNUs at the Cedar and Mill Creek sites. Mill Creek is in the most rapidly developing of the monitored watersheds, which may result in increased sediment runoff in the basin contributing to elevated turbidity. The Indian Creek site had the smallest turbidity most of the time because of the high clarity of WWTF discharge. Most of the time, $\mathrm{pH}$ and DO remained lower and water temperature higher at the Indian
Creek site compared to the other Johnson County monitoring sites because of WWTF discharges. From March 2004 through December 2006, DO concentrations were less than the Kansas aquatic-life-support criterion of $5.0 \mathrm{mg} / \mathrm{L}$ less than 10 percent of the time at all sites except Indian Creek, which had DO concentrations less than the criterion about 15 percent of the time.

Continuous data for three water-quality constituents (suspended sediment, chloride, and E. coli bacteria) were evaluated thoroughly in this report. These particular constituents were selected for additional discussion because they represent three major categories of concern in Johnson County streams (sediment, major ions, and bacteria) that have been identified as sources of water-quality impairment by KDHE. Regression models for nutrients, a fourth category of concern in Johnson County, generally had more variability than models for suspended sediment, chloride, and E. coli bacteria because of the larger variability in sources, fate, and transport in streams. Generally for most constituents, models for the less urban sites (Blue River and Kill Creek) contained less variability than models for the more urban sites (Indian and Mill Creeks). This is because water quality in urban areas is more complex because of multiple sources and often altered pathways. Sediment is statistically related to other water-quality constituents, and these relations have potential implications for implementation of best management practices (BMPs) in that if sediment concentrations decrease, concentrations of sediment-associated constituents such as suspended solids, some nutrients, and bacteria also will decrease.

Estimated concentrations of suspended sediment in 2005-06 ranged from a minimum of less than $3 \mathrm{mg} / \mathrm{L}$ at all five monitoring sites to a maximum of $4,600 \mathrm{mg} / \mathrm{L}$ at the Cedar Creek site in 2005 and the Blue River site in 2006. From March 2004 through December 2006, suspendedsediment concentration was nearly always largest at the Mill Creek site. The Mill Creek watershed is undergoing rapid development that likely is contributing to larger sustained sediment concentrations. About 70 percent of the time, the smallest sediment concentration occurred at the Indian Creek site, likely because most of the streamflow originated from treated WWTF discharge just upstream from the monitoring site. Estimated annual suspended-sediment loads and yields were largest annually at the Indian Creek site and annual loads were smallest at the Kill Creek site. At least 90 percent of the total annual load in 2005-06 at all five sites occurred during less than 2 percent of the time, generally associated with large storm runoff. The streamflow that was exceeded less than 2 percent of the time at the monitoring sites ranged from about $250 \mathrm{ft}^{3} / \mathrm{s}$ at the Cedar and Kill Creek sites to about 1,000 $\mathrm{ft}^{3} / \mathrm{s}$ at the Indian Creek site. About 50 percent of the 2005 sediment load at the Blue River site occurred during a 3-day storm, the equivalent of less than 1 percent of the time. The implication is that management practices designed to control sediment during small streamflows will have minimal effect on annual loads. During the 3- to 4-year period of record for the five monitoring sites, streamflow has only slightly exceeded the 
estimated 2-year peak streamflow at all sites except the Cedar and Kill Creek sites where streamflow has not exceeded the 2-year peak since monitoring began. Therefore, sediment load contributions when the 2-year streamflow is exceeded have not been well documented but are expected to be substantial.

Chloride concentrations from March 2004 through December 2006 were largest at the Indian and Mill Creek sites, the two most urban monitoring sites which also are most affected by road-salt runoff and WWTF discharges. Estimated chloride concentrations ranged from about $5 \mathrm{mg} / \mathrm{L}$ at the Cedar Creek site in 2006 to $1,500 \mathrm{mg} / \mathrm{L}$ at the Indian Creek site in 2006. About 10 percent of the time, the Indian and Mill Creek sites were noticeably affected by increased chloride concentrations as a result of road-salt runoff, while the Blue River and Kill Creek sites experienced no major effects from road-salt application. At the Indian Creek site during 2005-06, there was a 50-percent probability of chloride concentration exceeding the 250-mg/L USEPA Secondary Drinking-Water Regulation about 8 percent of the time, and exceeding the 860$\mathrm{mg} / \mathrm{L} \mathrm{KDHE}$ acute aquatic-life criterion less than 1 percent of the time. The effect of accumulated road salt on ground water and base flow throughout the remainder of the year is unknown. About 50 percent of the total chloride load during 2005-06 occurred in less than 10 percent of the time at all five monitoring sites. Two chloride runoff occurrences in JanuaryFebruary 2005 accounted for 19 percent of the total chloride load in Indian Creek in 2005.

From March 2004 through December 2006, E. coli density at the Indian Creek site was nearly always largest with a median density more than double that of any other monitoring site, and at least 15 times the density at the Blue River site. The KDHE primary contact criterion for recreation $(262 \mathrm{col} / 100 \mathrm{~mL})$ was exceeded about 65 percent of the time at the Indian Creek site, and the secondary criterion $(2,358 \mathrm{col} / 100 \mathrm{~mL})$ was exceeded about 10 percent of the time. At the other monitoring sites, the primary contact criterion was exceeded between about 8 and 25 percent of the time, and the secondary contact criterion was exceeded less than 5 percent of the time. The Blue River and Cedar Creek sites had the smallest bacteria densities most of the time. During 2005-06, more than 90 percent of the total E. coli bacteria load at the Cedar Creek site occurred in less than 1 percent of the time, generally associated with storm runoff, compared to the Indian Creek site where about 80 percent of the total E. coli load occurred during less than 1 percent of the time. The largest annual bacteria yields occurred at the Indian Creek site as well. Potential urban sources of bacteria in Indian Creek include leaky sewer lines, pet waste, wildlife, WWTF discharges and bypasses, and unauthorized dumping. Potential nonurban sources of bacteria in less urban watersheds include livestock, leaky septic systems, and wildlife. Fecal coliform loads originating from two WWTFs on Indian Creek contributed less than 3 percent of the downstream estimated fecal coliform bacteria load at the Indian Creek monitoring site. When fecal coliform bacteria load from the Blue River WWTF, which discharges just downstream from the Blue River monitoring site, was added to the total load at the Blue River monitoring site, less than 1 percent of the total downstream Blue River fecal coliform bacteria load originated from the WWTF. More than 97 percent of the fecal coliform bacteria load in Indian Creek and the Blue River originated from nonpoint sources.

Although nutrients originated from both point and nonpoint sources, the largest total nitrogen concentrations in discrete samples generally occurred at the Indian Creek monitoring site during streamflows less than $200 \mathrm{ft}^{3} / \mathrm{s}$ and were primarily in the form of nitrate, indicating that WWTFs were likely the primary source. Total nitrogen discharged from the two Indian Creek WWTFs accounted for about 65 percent of estimated total nitrogen load at the downstream Indian Creek monitoring site in 2005 and 90 percent of the downstream estimated total nitrogen load in 2006 when stormwater runoff was less. Total phosphorus load from the Indian Creek WWTFs was at least 90 percent of the total phosphorus load at the downstream monitoring site in 2005 and 2006. Larger concentrations of nutrients in stormwater at nonurban sites, including the Blue River and Cedar and Kill Creek sites, indicated the nonpoint sources are predominant. However, downstream from the Blue River monitoring site where the WWTF discharges to the river, about 40 percent of the total nitrogen load in 2005 and 70 percent of the total nitrogen load in 2006 originated from the WWTF. One-fourth (in 2005) to one-half (in 2006) of the downstream total phosphorus load in the Blue River originated from WWTF discharges.

Regression models for providing continuous estimates of pesticides in Johnson County streams were not developed because no continuously measured explanatory variables were found to be significant. Mixed land uses and complex sources and pathways in Johnson County watersheds likely contributed to large statistical variability in the relations between variables. Discrete-sample analysis indicated that many of the same pesticides frequently found nationwide also were most common in Johnson County streams. Atrazine (an herbicide often used in crop production) and its degradates were common at all monitoring sites. Prometon (an extensively used urban herbicide) also was detected in the majority of samples at each site. Metolachlor (a common agricultural herbicide) was found in the majority of samples at all sites except Kill Creek, where it was detected in about one-half of the samples. Simazine (another extensively used herbicide usually associated with urban uses) was found in samples from all five sites but was detected most frequently and generally in the largest concentrations in samples from the Cedar Creek site. The largest concentrations of all pesticides occurred in samples collected during storm runoff, usually in the spring.

Water-quality conditions at the five monitoring sites generally depended on hydrologic conditions, land use, percentage of urbanization, and relative contributions from point and nonpoint constituent sources. Precipitation, primarily the amount, frequency, and intensity of rainfall, is the fundamental factor contributing to streamflow and affecting transport of nonpoint contaminants. WWTF discharge is the primary 
source of streamflow during base flow. In Johnson County, generally as impervious surface area increased, so did total annual yield for many water-quality constituents in 2005 and 2006. Most contaminants in Johnson County streams, including suspended sediment, indicator bacteria, some nutrients, and most pesticides, originate primarily from nonpoint sources, primarily overland flow during storm runoff.

Continuous in-stream water-quality monitoring of Johnson County streams provided the foundation for a comprehensive evaluation of variability and chemical-loading characteristics for water-quality constituents including suspended sediment, selected major ions, indicator bacteria, and some nutrient species. The results presented in this report may be used to better understand constituent concentration and load fluctuations, range, and variability during changing seasonal and flow conditions and to assess water-quality conditions relative to TMDLs, NPDES requirements, and water-quality standards. The baseline information also will be useful for evaluating future changes in land use and effectiveness of implemented BMPs.

\section{References Cited}

American Public Health Association, American Water Works Association, and Water Environment Association, 1995, Standard methods for the examination of water and wastewater (18th ed): Washington, D.C., American Public Health Association, 905 p.

Anderson, C.W., 2005, Turbidity, in National field manual for the collection of water-quality data: U.S. Geological Survey Techniques of Water-Resources Investigations, book 9, chap. 6.7, p. 1-59.

Arnold, C.A, and Gibbons, J.C., 1996, Impervious surface coverage - the emergence of a key environmental indicator: Journal of the American Planning Association, v. 22, no. 2, p. 243-257.

Asselman, N.E.M., 1999, Suspended sediment dynamics in a large basin - the Rhine River: Hydrologic Processes, v. 13, p. $1437-1450$.

Buchanan, T.J., and Somers, W.P., 1969, Discharge measurements at gaging stations: U.S. Geological Survey Techniques of Water-Resources Investigations, book 3, chap. A8, $65 \mathrm{p}$.

ASTM International, 2003, D1889-00 standard test method for turbidity of water, in ASTM International, Annual book of ASTM standards, water and environmental technology: West Conshohocken, Pennsylvania, American Society for Testing and Materials, v. 11.01, 6 p.
Blevins, D.W., 1986, Quality of stormwater runoff in the Blue River basin, Missouri and Kansas, July-October 1981 and April-July 1982: U.S. Geological Survey Water-Resources Investigations Report 84-4226, 131 p.

Booth, D.B., 1990, Stream channel incision following drainage-basin urbanization: Water Resources Bulletin, v. 26, p. $407-17$.

Christensen, V.G., Jian, X., and Ziegler, A.C., 2000, Regression analysis and real-time water-quality monitoring to estimate constituent concentrations, loads, and yields, in the Little Arkansas River, south-central Kansas, 1995-99: U.S. Geological Survey Water-Resources Investigations Report 00-4126, 36 p.

Cohn, T.A., DeLong, L.L., Gilroy, E.J., Hirsch, R.M., and Wells, D., 1989, Estimating constituent loads: Water Resources Research, v. 25, no. 5, p. 937-942.

Cromwell, A.E., and Thurman, E.M., 2000, Atmospheric transport, deposition, and fate of triazine herbicides and their metabolites in pristine areas at Isle Royale National Park: Environmental Science and Technology, v. 34, p. 3079-3085.

Devlin, D.L., and McVay, K.A., 2001, Suspended solids-a water quality concern for Kansas: Kansas State University Agricultural Experiment Station and Cooperative Extension Service, TMDL Fact Sheet No. 6, 2 p.

Dodds, W.K., 2002, Freshwater ecology: San Diego, Academic Press, p. 69-111.

Driver, N.E., and Troutman, B.M., 1989, Regression models for estimating urban storm runoff quality and quantity in the United States: Journal of Hydrology, v. 109, no. 3/4, p. 221-236.

Duan, N., 1983, Smearing estimate-a nonparametric retransformation method: Journal of the American Statistical Association, v. 78, p. 605-610.

Dufour, A.P., 1977, Escherichia coli-fecal coliform, in Hoadley, A.W., and Dutka, B.J., eds., Bacterial indicator/health hazards associated with water, 1977: American Society for Testing and Materials, ASTM STP 635, p. 48-58.

Dunne, T., and Leopold, L.B., 1978, Water in environmental planning: San Francisco, Freeman and Company, 818 p.

Edwards, K.E., and Glysson, G.D., 1999, Field methods for measurement of fluvial sediment: U.S. Geological Survey Techniques of Water-Resources Investigations, book 3, chap. C2, 89 p. 
Faires, L.M., 1993, Methods of analysis by the U.S. Geological Survey National Water-Quality Laboratory-determination of metals in water by inductively coupled plasmamass spectrometry: U.S. Geological Survey Open-File Report 92-634, 28 p.

Finkenbine, J.K., Atwater, J.W., and Mavinic, D.S., 2000, Stream health after urbanization: Journal of the American Water Resources Association, v. 36, p. 1149-1160.

Fishman, M.J., ed., 1993, Methods of analysis by the U.S. Geological Survey National Water-Quality Laboratorydetermination of inorganic and organic constituents in water and fluvial sediments: U.S. Geological Survey Open-File Report 93-125, 217 p.

Fishman, M.J., and Friedman, L.C., 1989, Methods for determination of inorganic substances in water and fluvial sediments: U.S. Geological Survey Techniques of WaterResources Investigations, book 5, chap. A1, 545 p.

Francy, D.S., and Darner, R.A., 2006, Procedures for developing models to predict exceedances of recreational waterquality standards at coastal beaches: U.S. Geological Survey Techniques and Methods 6-B5, 34 p.

Galli, F.J., 1991, Thermal impacts associated with urbanization and stormwater management best management practices: Washington, D.C., Metropolitan Washington Council of Governments, p. 123-141.

Gilliom, R.J., Barbash, J.E., Crawford, C.G., Hamilton, P.A., Martin, J.D., Nakagaki, N., Nowell, L.H., Scott, J.C., Stackelberg, P.E., Thelin, G.P., and Wolock, D.M., 2006, The quality of our Nation's waters-pesticides in the Nation's streams and ground water, 1992-2001: U.S. Geological Survey Circular 1291, 172 p.

Goolsby, D.A., and Battaglin, W.A., 1993, Occurrence, distribution and transport of agricultural chemicals in surface waters of the Midwestern United States, in Goolsby, D.A., Boyer, L.L., and Mallard, G.E., eds., Selected papers on agricultural chemicals in water resources of the Midcontinental United States: U.S. Geological Survey Open-File Report 93-418, p. 1-25.

Gray, J.R., Glysson, G.D., Turcios, L.M., and Schwarz, G.E., 2000, Comparability of suspended-sediment concentration and total suspended solids data: U.S. Geological Survey Water-Resources Investigations Report 00-4191, 14 p.

Guy, H.P., 1969, Laboratory theory and methods for sediment analysis: U.S. Geological Survey Techniques of WaterResources Investigations, book 5, chap. C1, 58 p.

Hampson, P.S., Treece, M.W., Jr., Johnson, G.C., Ahlstedt, S.A., and Connell, J.F., 2000, Water quality in the upper Tennessee River Basin, North Carolina, Virginia, and Georgia, 1994-98: U.S. Geological Survey Circular 1205, 32 p.
Heaney, J.P., and Huber, W.C., 1984, Nationwide assessment of urban runoff on receiving water quality: Water Resources Bulletin, v. 20, p. 35-42.

Helsel, D.R., and Hirsch, R.M., 2002, Statistical methods in water resources-hydrologic analysis and interpretation: Techniques of Water-Resources Investigations of the U.S. Geological Survey, chap. A3, book 4, 510 p.

Hem, J.D., 1966, Chemical controls of irrigation drainage water composition: American Water Resources Conference, 2d, Chicago 1966, Proceedings, p. 64-77.

Hem, J.D., 1992, Study and interpretation of chemical characteristics of natural water (3d ed.): U.S. Geological Survey Water-Supply Paper 2254, 263 p.

Hirsch, R.M., Helsel D.R., Cohn, T.A., and Gilroy, E.J., 1993, Statistical analysis of hydrologic data, in Maidment, D.R., ed., Handbook of hydrology: New York, McGraw-Hill, Inc., p. 17.1-17.55.

Hirsch, R.M., Walker, J.F., Day, J.C., and Kallio, R., 1990, The influence of man on hydrologic systems, in Riggs, H.C., and Wolman, M.G., eds., Surface water hydrology-the geology of America, volume O-1: Boulder, Colorado, Geological Society of America, pp. 329-359.

Huggins, D.G., and Anderson, J., 2005, Dissolved oxygen fluctuation regimes in streams of the western corn belt plains ecoregion: Kansas Biological Survey Report No. 130, $56 \mathrm{p}$.

Johnson County Stormwater Management Program, 2007, Stormwater Management Advisory Council, Information available on Web, accessed October 30, 2007, at http://stormwater.jocogov.org/AboutSMP/smac.shtml

Jordan, P.R., and Stamer, J.K., eds., 1995, Surface-water-quality assessment of the lower Kansas River Basin, Kansas and Nebraska, analysis of data through 1986: U.S. Geological Survey Water-Supply Paper 2352-B, 161 p.

Kansas Department of Health and Environment, 2004a, Basics of TMDLs: Information available on Web, accessed July 30, 2004, at http://www.kdhe.state.ks.us/tmdl/ basic.htm

Kansas Department of Health and Environment, 2004b, Surface Water Nutrient Reduction Plan, December 2004: Information available on Web, accessed February 9, 2005, at $h t t p: / / w w w . k d h e . s t a t e . k s . u s / w a t e r / d o w n l o a d /$ ks_nutrient_reduction_plan_12_29_final.pdf

Kansas Department of Health and Environment, 2005, Kansas Administrative Regulations (KAR), Title 28, Article 16, Surface water quality standards 2005: Topeka, Kansas, Secretary of State, multiple pagination. 
Kansas Department of Health and Environment, 2006a, Kansas section 303(d) list of impaired surface waters: Information available on Web, accessed April 2007 at http://www.kdheks.gov/tmdl/methodology.htm

Kansas Department of Health and Environment, 2006b, Kansas-Lower Republican Basin total maximum daily load, waterbody-Cedar Creek watershed, water quality impairment-nitrate: Information available on Web, accessed May 2007 at http://www.kdheks.gov/tmdl/2006/ new_cedar_creek_nitrate_tmdl.pdf

Kansas Department of Health and Environment, 2007, KansasLower Republican Basin total maximum daily load, waterbody-Mill Creek watershed, water quality impairmentbiology: Information available on Web, accessed May 2007 at http://www.kdheks.gov/tmdl/2006/ new_mill_creek_bio_tmdl.pdf

Kaushal, S.S., Groffman, P.M., Likens, G.E., Belt, K.T., Stack, W.P., Kelly, W.K., Band, L.E., and Fisher, G.T., 2005, Increased salinization of fresh water in the northeastern United States: Proceedings of National Academy of Sciences, v. 102, p. 13517-13520.

Kiely, T., Donaldson, D., and Grube, A., 2004, Pesticides industry sales and usage, 2000 and 2001 market estimates: Information available on Web, accessed January 24, 2005, at http://www.epa.gov/oppbead1/pestsales/01pestsales/ market_estimates2001.pdf

LeBlanc, R.T., Brown, R.D., and Fitzgibbon, J.E., 1997, Modeling the effects of land use change on water temperature in unregulated urban streams: Journal of Environmental Monitoring, v. 49, p. 445-469.

Lee, C.J., Mau, D.P., and Rasmussen, T.J., 2005, Effects of point and nonpoint sources on water quality and relation to land use in Johnson County, northeastern Kansas, October 2002 through June 2004: U.S. Geological Survey Scientific Investigations Report 2005-5144, 104 p.

Leopold, L.B., 1968, Hydrology for urban land planning-a guidebook on the hydrologic effects of urban land use: U.S. Geological Survey Circular 554, 18 p.

Lewis, M.E., 2006, Dissolved oxygen: U.S. Geological Survey Techniques of Water Resources Investigations, book 9, chap. A6, section 6.2, accessed February 2007 from http://pubs.water.usgs.gov/twri9A6

Maidment, 1993, Handbook of hydrology: New York, McGraw-Hill, Inc., variously paged.

Masters, G.M., 1991, Introduction to environmental engineering and science: Englewood Cliffs, New Jersey, Prentice Hall, p. 110-111.
Mau, D.P., Ziegler, A.C., Porter, S.D., and Pope, L.M., 2004, Surface-water-quality conditions and relation to taste-andodor occurrences in the Lake Olathe watershed, northeast Kansas, 2000-02: U.S. Geological Survey Scientific Investigations Report 2004-5047, 95 p.

McMahon, G., and Cuffney, T.F., 2000, Quantifying urban intensity in drainage basins for assessing stream ecological condition: Journal of the American Water Resources Association, v. 36, no. 6, p. 1247-1261.

Mid-America Regional Council, 2002, Long-range forecast for the Kansas City metropolitan area, 2002: Information available on Web, accessed December 17, 2004, at

http://www.metrodataline.org/Forecasts 2002\%20Long\%20Range\%20Forecasts.xls

Mid-America Regional Council and American Public Works Association, 2003, Manual of best management practices for stormwater quality: Information available on Web, accessed May 24, 2007, at http://www.marc.org/ Environmental/Water/pdfs/bmp_manual/

Mid-America Regional Council and F.X. Browne and Associates, Inc., 1983, Nationwide Urban Runoff Program-Kansas City area project-executive and technical summaries: Kansas City, Missouri, Mid-America Regional Council, 16 p.

National Atmospheric Deposition Program, 2005, National atmospheric deposition program 2004 annual summary: NADP Data Report 2005-01, 16 p.

National Oceanic and Atmospheric Administration, 1966-98, Climatological data annual summary-east-central Kansas: Asheville, North Carolina, National Weather Service Climatic Data Center, published monthly.

Nistor, C.J., and Church, M., 2005, Suspended sediment transport regime in a debris-flow gully on Vancouver Island, British Columbia: Hydrological Processes, v. 19, p. 861-885.

Oberg, K.A., Morlock, S.E., and Caldwell, W.S., 2005, Quality-assurance plan for discharge measurements using Acoustic Doppler Current Profilers: U.S. Geological Survey Scientific Investigations Report 2005-5183, 35 p.

O’Connor, H.G., 1971, Johnson County geohydrology: Kansas Geological Survey, information available on Web, accessed June 25, 2007, at http://www.kgs.ku.edu/General/Geology/ Johnson/index.html

Paul, M.J., and Meyer, J.L., 2001, Streams in the urban landscape: Annual Review of Ecological Systems, v. 32, p. 333-65.

Perry, C.A., Wolock, D.M., and Artman, J.A., 2004, Estimates of flow duration, mean flow, and peak-discharge frequency values for Kansas stream locations: U.S. Geological Survey Scientific Investigations Report 2004-5033, 219 p. 
Peters, N.E., and Meybeck, M., 2000, Water quality degradation effects on freshwater availability-impacts of human activities: International Water Resources Association, Water International, v. 25, no. 2, p. 185-193.

Plinsky, R.O., Zimmerman, J.L., Dickey, H.P., Jorgensen, G.N., Fenwick, R.W., and Roth, W.E., 1975, Soil survey of Johnson County, Kansas: U.S. Department of Agriculture, Soil Conservation Service, 93 p.

Pope, L.M., and Putnam, J.E., 1997, Effects of urbanization on water quality in the Kansas River, Shunganunga Creek Basin and Soldier Creek, Topeka, Kansas, October 1993 through September 1995: U.S. Geological Survey WaterResources Investigations Report 97-4045, 84 p.

Porcella, D.B., and Sorensen, D.L., 1980, Characteristics of non-point source urban runoff and its effects on stream ecosystems: Washington, D.C., U.S. Environmental Protection Agency, EPA-600/3-80-032, 99 p.

Poulton, B.P., Rasmussen, T.J., and Lee, C.J., 2007, Assessment of biological conditions at selected stream sites in Johnson County, Kansas, and Cass and Jackson Counties, Missouri, 2003 and 2004: U.S. Geological Survey Scientific Investigations Report 2007-5108, 68 p.

Putnam, J.E., 1997, Occurrence of phosphorus, other nutrients, and triazine herbicides in water from the Hillsdale Lake Basin, northeast Kansas, May 1994 through May 1995: U.S. Geological Survey Water-Resources Investigations Report 97-4019, 66 p.

Radtke, D.B., Davis, J.V., and Wilde, F.D., 2005, Specific electrical conductance: U.S. Geological Survey Techniques of Water Resources Investigations, book 9, chap. A6, section 6.3, accessed October 2007 at http://pubs.water.usgs. gov/twri9A9/

Rasmussen, P.P., and Ziegler, A.C., 2003, Comparison and continuous estimates of fecal coliform and Escherichia coli bacteria in selected Kansas streams, May 1999 through April 2002: U.S. Geological Survey Water-Resources Investigations Report 03-4056, 80 p.

Rasmussen, T.J., Ziegler, A.C., and Rasmussen, P.P., 2005, Estimation of constituent concentrations, densities, loads, and yields in lower Kansas River, northeast Kansas, using regression models and continuous water-quality monitoring, January 2000 through December 2003: U.S. Geological Survey Scientific Investigations Report 2005-5165, 117 p.

Ritter, M.E., 2006, The physical environment: an introduction to physical geography: Information found on the Web, accessed July 31, 2007 at http://www.uwsp.edu/geo/faculty/ ritter/geog101/ textbook/

Schoewe, W.H., 1949, The geography of Kansas: Transactions of the Kansas Academy of Science, v. 52, no. 3, p. 261-333.
Seaburn, G.E., 1969, Effects of urban development on direct runoff to East Meadow Brook, Nassau County, New York: U.S. Geological Survey Professional Paper 627-B, 14 p.

Searcy, J.K., 1959, Flow duration curves, manual of hydrology, part 2, low flow techniques: U.S. Geological Survey Water Supply Paper 1542-A, 33 p.

Smith, R.A., Alexander, R.B., and Schwartz, G.E., 2003, Natural background concentrations of nutrients in streams and rivers of the conterminous United States: Environmental Science and Technology, v. 37, no. 14, p. 3039-3047.

Trimble, S.J., 1997, Contribution of stream channel erosion to sediment yield from an urbanizing watershed: Science, v. 278 , p. $1442-1444$.

University of Kansas, 2006, Kansas statistical abstract 2005 (40th ed.), Lawrence, Kansas, Institute for Policy and Social Research, available on Web accessed June 18, 2007 at http:/www.ipsr.ku.edu/ksdata/ksaht.

U.S. Census Bureau, 2007, State and county quickfacts: Information available on Web accessed June 18, 2007, at http://quickfacts.census.gov/qfd/states/20000.html .

U.S. Environmental Protection Agency, 2002a, Source Water Protection Practices Bulletin-Managing highway deicing to prevent contamination of drinking water: Washington, D.C., EPA 816-F-02-019, 7 p.

U.S. Environmental Protection Agency, 2002b, List of drinking water contaminants \& MCLs, July 2002: Washington, D.C., EPA-816-F-02-013, information available on Web, accessed July 12, 2004, at http://www.epa.gov/safewater mcl.htm

U.S. Environmental Protection Agency, 2003a, National drinking-water standards, June 2003: Washington D.C., Report EPA-816-F-03-016, information available on Web, accessed July 12, 2004, at http://www.epa.gov/safewater mcl.html

U.S. Environmental Protection Agency, 2003b, Ecoregional nutrient criteria: Information available on Web, accessed July 9, 2003, at http://www.epa.gov/waterscience/criteria/ nutrient/ecoregions/

U.S. Environmental Protection Agency, 2004a, Which atmospheric deposition pollutants pose the greatest problems for water quality?: Information available on Web, accessed November 4, 2004, at http://www.epa.gov/owow/oceans, airdep/air2.htm

U.S. Environmental Protection Agency, 2004b, Primer for municipal wastewater treatment systems: Washington, D.C., EPA-832-R-04-001, 29 p. 
U.S. Environmental Protection Agency, 2005, National Pollutant Discharge Elimination System (NPDES): Information available on Web, accessed February 2006 at http://cfpub. epa.gov/npdes

U.S. Environmental Protection Agency, 2007, Introduction to the clean water act: Information available on the Web, accessed September 2007 at http://www.epa.gov/ watertrain/cwal

U.S. Geological Survey, 1999, The quality of our Nation's waters - nutrients and pesticides: U.S. Geological Survey Circular 1225, 82 p.

Vogel, R.M., and Fennessey, N.M., 1995, Flow duration curves II-a review of applications in water resources planning: Water Resources Bulletin, v. 31, no. 6, p. 1029-1039.

Wagner, R.J., Boulger, R.W., Jr., Oblinger, C.J., and Smith, B.A., 2006, Guidelines and standard procedures for continuous water-quality monitors: station operation, record computation, and data reporting: U.S. Geological Survey Techniques and Methods 1-D3, 96 p.

Wagner, R.J., Mattraw, H.C., Ritz, G.F., and Smith, B.A., 2000, Guidelines and standard procedures for continuous water-quality monitors-site selection, field operations, calibration, record computation, and reporting: U.S. Geological Survey Water-Resources Investigations Report 00-4252, $53 \mathrm{p}$.

Water One, 2004, Water District No. 1 of Johnson Countydrinking water quality report 2004: Information available on Web, accessed October 2004 at http://www.waterone.org Adobe\%20Files/2004\%20Water\%20Quality\%20Report_1. pdj

Weibull, W., 1939, The phenomenon of rupture in solids, ingenious Vetenskaps: Stockholm, Akademien Handlingo, v. 153, p. 17.

Welch, E.B., and Lindell, T., 1992, Ecological effects of wastewater, applied limnology and pollutant effects: London and New York, Cambridge University Press, 425 p.

Wetzel, R.G., 2001, Limnology of lake and river ecosystems: New York, Academic Press, 1006 p.

Wilde, F.D., and Radtke, D.B., eds., 1998, Field measurements, in National field manual for the collection of waterquality data: U.S. Geological Survey Techniques of WaterResources Investigations, book 9, chap. A6, p. 3-20.
Wilde, F.D., Radtke, D.B., Gibs, J., and Iwatsubo, R.T., eds., 1999, Collection of water samples, in National field manual for the collection of water-quality data: U.S. Geological Survey Techniques of Water-Resources Investigations, book 9, chap. A4, various pagination.

Wilde, F.D., Eurybiades, B., and Radtke, D.B., 2006, pH: U.S. Geological Survey Techniques of Water Resources Investigations, book 9, chap. A6, section 6.4, accessed February 2007 from pubs://pubs.water.usgs.gov/twri9A6

Wilkison, D.H., Armstrong, D.J., and Blevins, D.W., 2002, Effects of wastewater and combined sewer overflows on water quality in the Blue River Basin, Kansas City, Missouri and Kansas, July 1998-October 2000: U.S. Geological Survey Water Resources Investigations Report 02-4107, 162 p.

Wilkison, D.H., Armstrong, D.J., Brown, R.E., Poulton, B.C., Cahill, J.D., and Zaugg, S.D., 2005, Water-quality and biologic data for the Blue River Basin, Kansas City Metropolitan area, Missouri and Kansas, October 2000 to October 2004: U.S. Geological Survey Data Series 127, 158 p.

Wilkison, D.H., Armstrong, D.J., Norman, R.D, Poulton, B.C., Furlong, E.T., and Zaugg, S.D., 2006, Water-quality in the Blue River Basin, Kansas City metropolitan area, Missouri and Kansas, July 1998 to October 2004: U.S. Geological Survey Scientific Investigations Report 2006-5147, 170 p.

Williams, G.P., 1989, Sediment concentration versus water discharge during single hydrologic events in rivers: Journal of Hydrology, v. 11, p. 89-106.

Wolman, M.G., 1967, A cycle of sedimentation and erosion in urban river channels: Geography Annual, v. 49a, p. 385-95.

Zampella, R.A., 1994, Characterization of surface water quality along a watershed disturbance gradient, Water Resources Bulletin, v. 30, p. 1605-611.

Zaugg, S.D., Sandstrom, M.W., Smith, S.G., and Fehlberg, K.M., 1995, Methods of analysis by the U.S. Geological Survey National Water-Quality Laboratory-determination of pesticides in water by $\mathrm{C}-18$ solid phase extraction and capillary-column gas chromatography/mass spectrometry with selected-ion monitoring: U.S. Geological Survey Open-File Report 95-181, 60 p. 
Appendix 


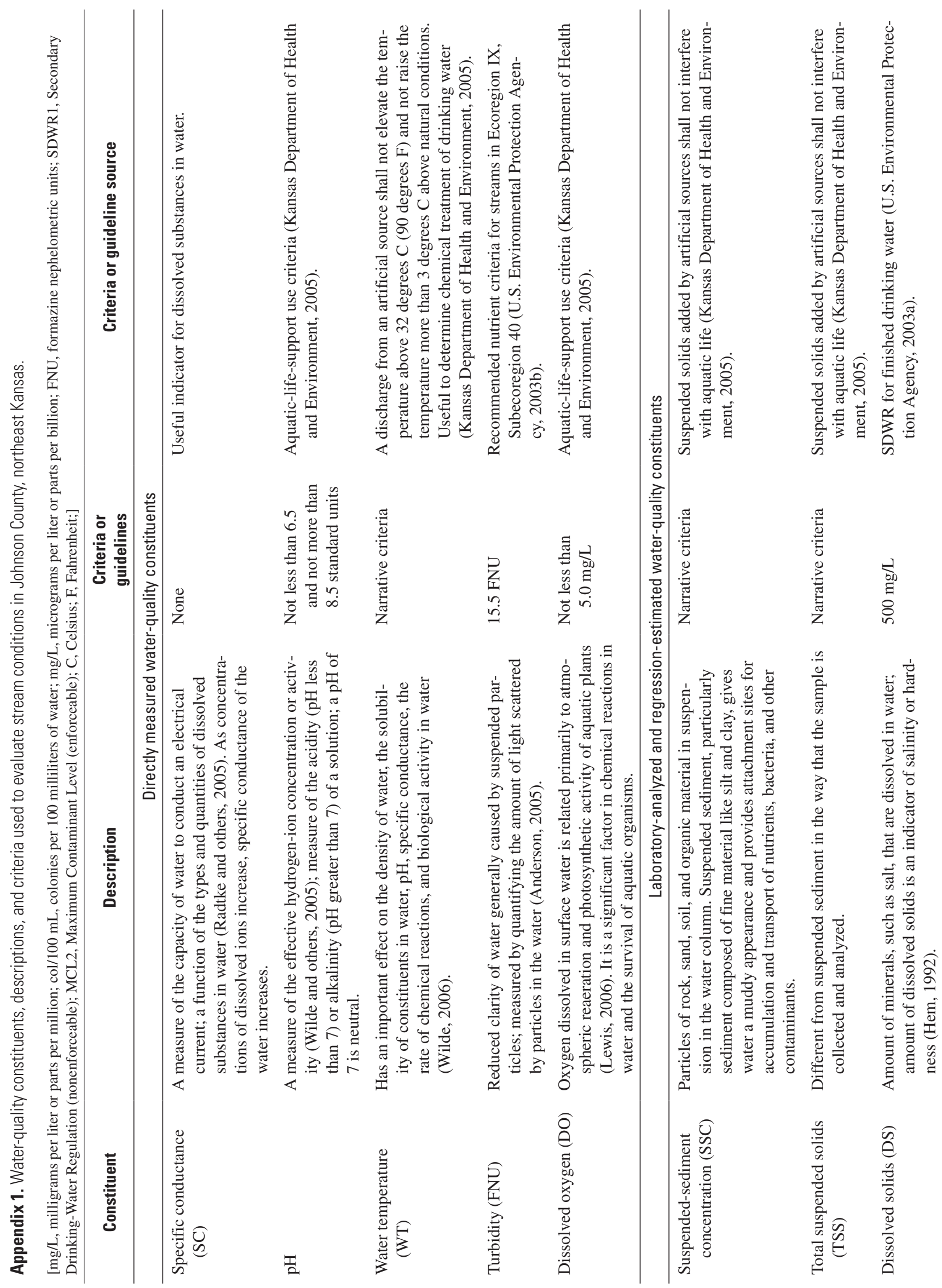




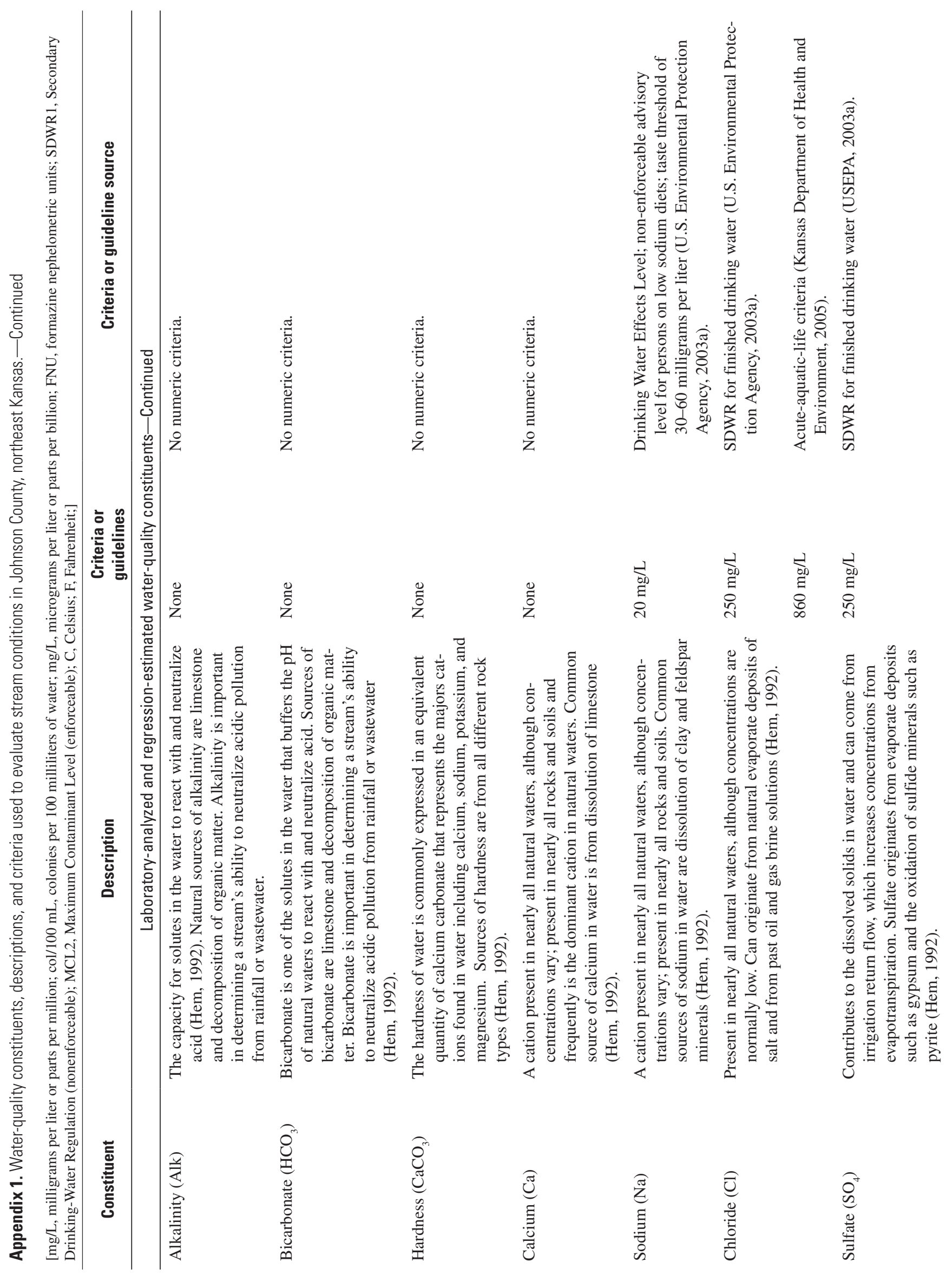




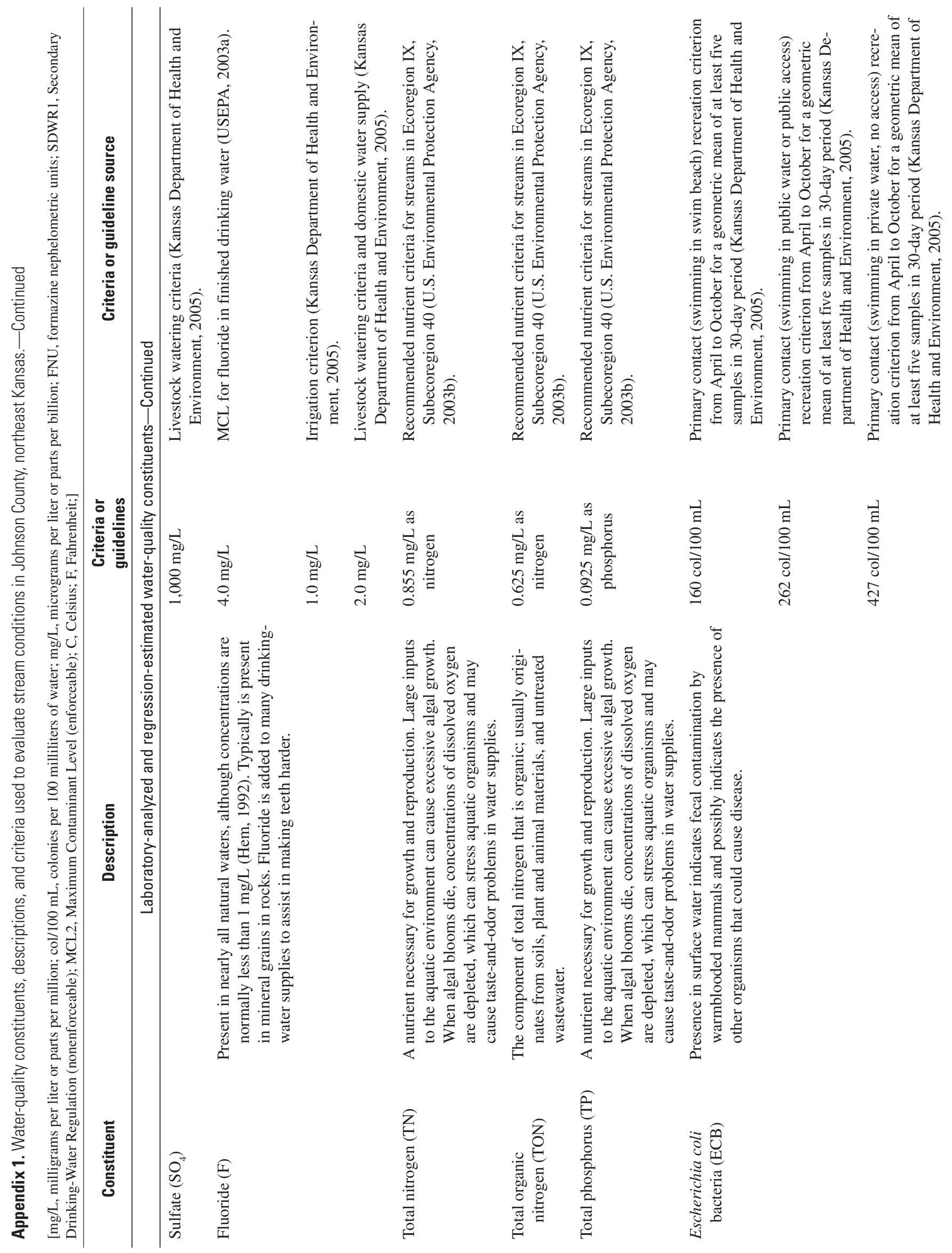




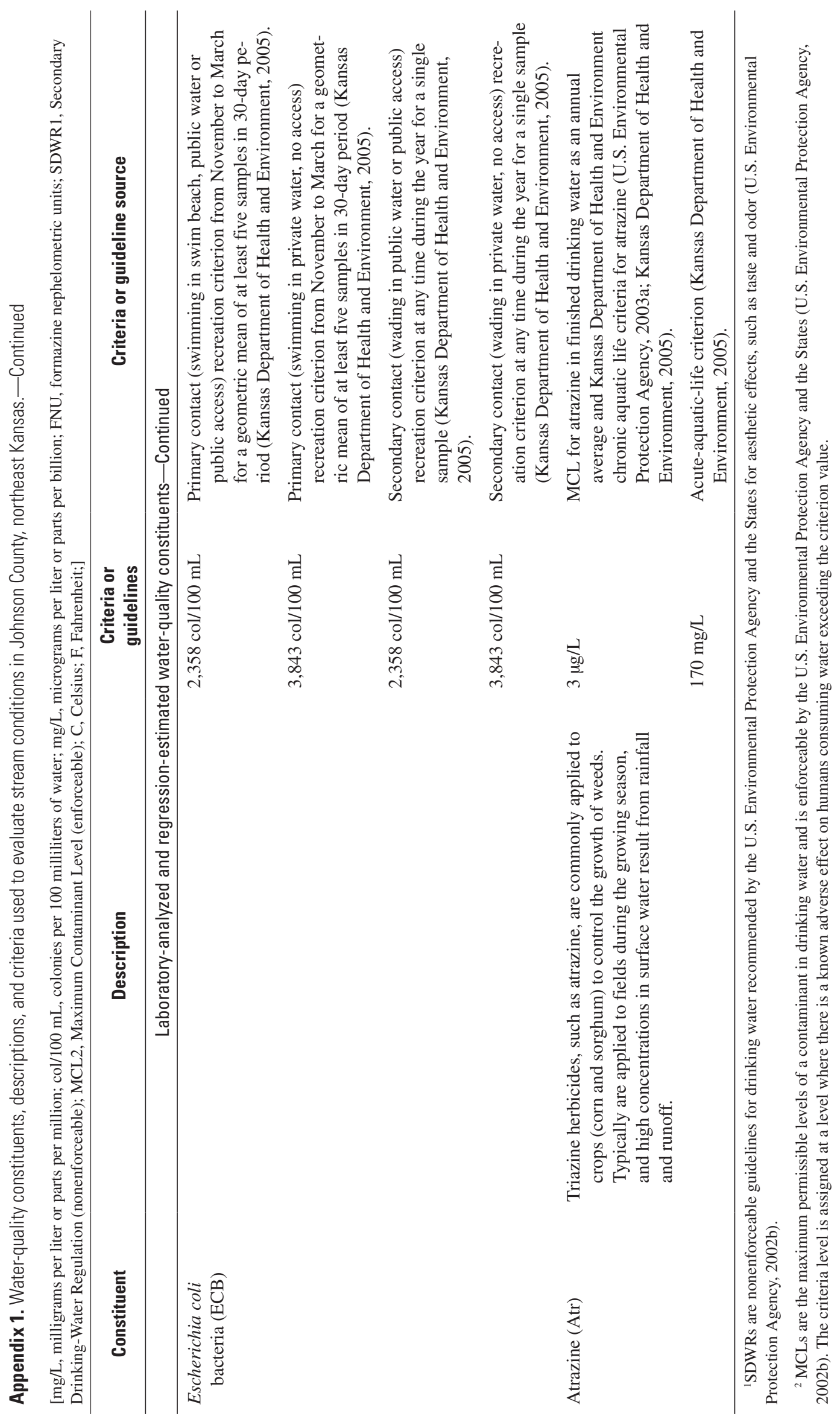


Publishing support provided by:

Rolla Publishing Service Center

For more information concerning this publication, contact:

Director, USGS Kansas Water Science Center

4821 Quail Crest Place

Lawrence, KS 66049

(785) 842-9909

Or visit the Kansas Water Science Center Web site at: http://ks.water.usgs.gov 


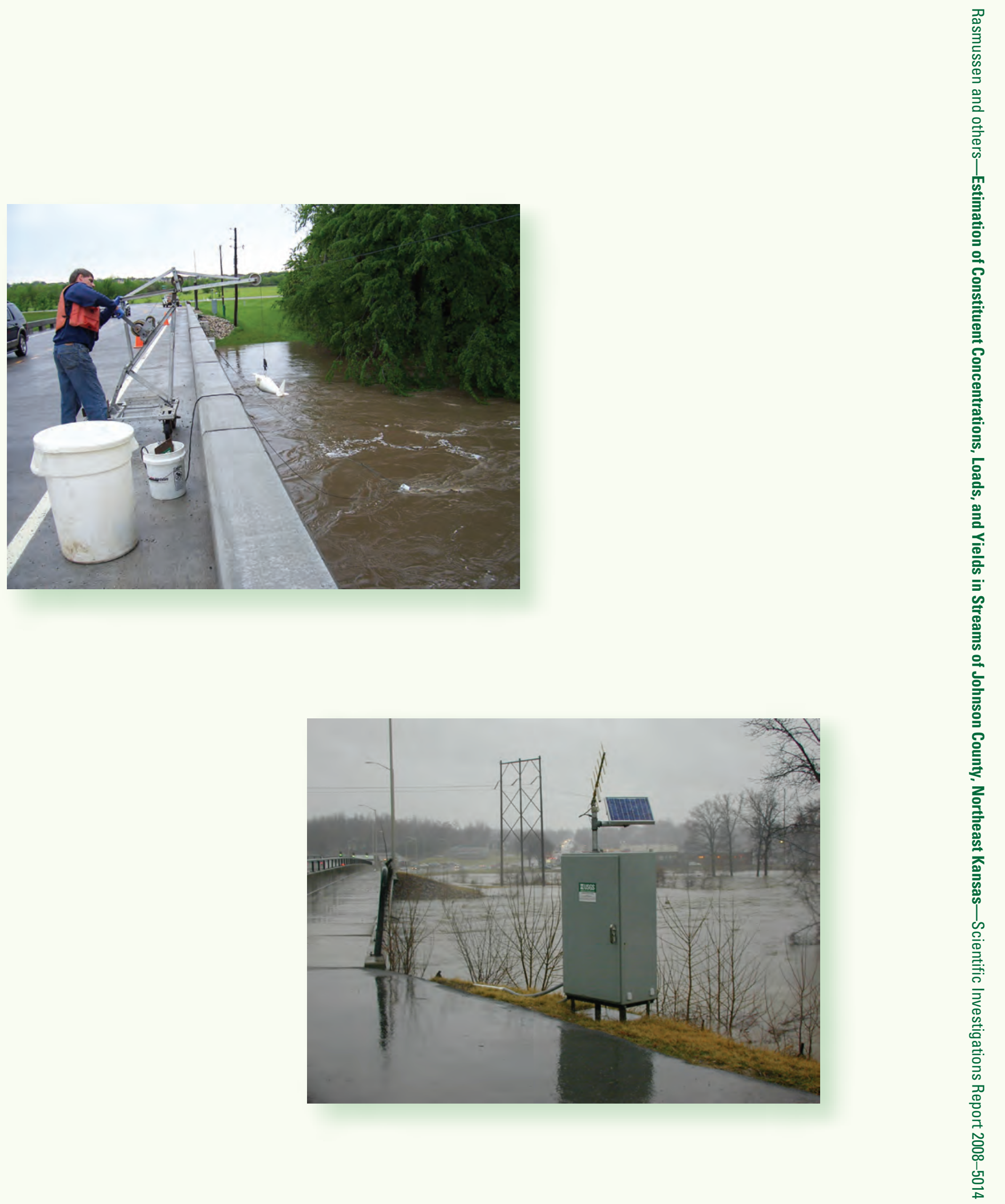

9 Printed on recycled paper

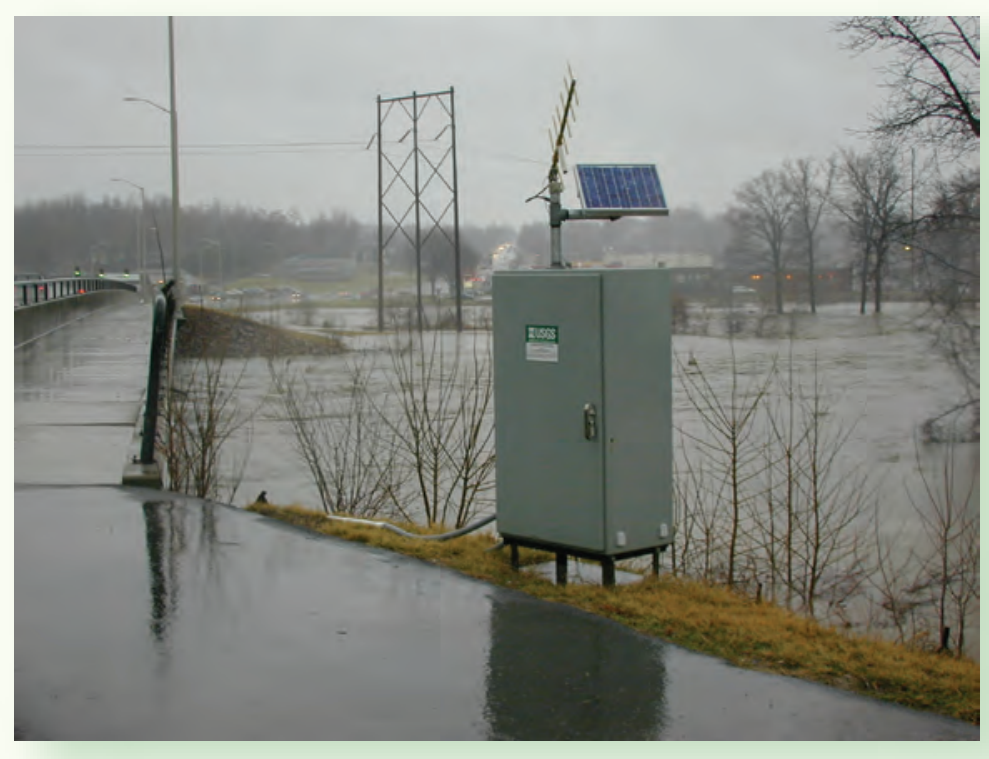

